\begin{abstract}
UNIVERSIDADE DE SÃO PAULO
ESCOLA DE ARTES, CIÊNCIAS E HUMANIDADES

PROGRAMA DE PÓS-GRADUAÇÃO EM MUDANÇA SOCIAL E PARTICIPAÇÃO POLÍTICA
\end{abstract}

PAULA FERNANDA DO VALLE

Conflitos e possibilidades da participação de comunidades locais na gestão do Parque Estadual da Ilha do Cardoso, São Paulo 


\title{
Conflitos e possibilidades da participação de comunidades locais na gestão do Parque Estadual da Ilha do Cardoso, São Paulo
}

\author{
Versão corrigida
}

Dissertação apresentada à Escola de Artes, Ciências e Humanidades da Universidade de São Paulo para obtenção do título de Mestre em Ciências do Programa de Pós-Graduação em Mudança Social e Participação Política.

Versão corrigida contendo as alterações solicitadas pela comissão julgadora em 05 de setembro de 2016. A versão original encontra-se em acervo reservado na Biblioteca da EACH/USP e na Biblioteca Digital de Teses e Dissertações da USP (BDTD), de acordo com a Resolução CoPGr 6018, de 13 de outubro de 2011.

\section{Área de concentração:}

Participação Política e Desenvolvimento Local

\section{Orientador:}

Professor Doutor Sidnei Raimundo 
Autorizo a reprodução e divulgação total ou parcial deste trabalho, por qualquer meio convencional ou eletrônico, para fins de estudo e pesquisa, desde que citada a fonte.

Valle, Paula Fernanda do

Conflitos e possibilidades da participação de comunidades locais na gestão do Parque Estadual da Ilha do Cardoso, São Paulo / Paula Fernanda do Valle ; orientador, Sidnei Raimundo. - São Paulo, 2016 191 p. : il

Dissertação (Mestrado em Ciências) - Programa de PósGraduação em Mudança Social e Participação Política, Escola de Artes, Ciências e Humanidades, Universidade de São Paulo Versão corrigida

1. Gestão ambiental - Ilha do Cardoso (SP). 2. Áreas de conservação - São Paulo. 3. Participação comunitária - Ilha do Cardoso (SP). I. Raimundo, Sidnei, orient. II. Título 
Nome: VALLE, Paula Fernanda do

Título: Conflitos e possibilidades da participação de comunidades locais na gestão do Parque Estadual da Ilha do Cardoso.

Dissertação apresentada à Escola de Artes, Ciências e Humanidades da Universidade de São Paulo para obtenção do título de Mestre em Ciências do Programa de Pós-Graduação em Mudança Social e Participação Política.

Área de concentração:

Participação Política e Desenvolvimento Local

Aprovada em: 05/09/2016

\section{Banca Examinadora}

Profa. Dra. Eliane Simões

Instituição: Universidade Estadual de Campinas

Prof. Dr. Reinaldo Tadeu Boscolo Pacheco

Instituição: Universidade de São Paulo

Prof. Dr. Rodrigo Constante Martins

Instituição: Universidade Federal de São Carlos 
Aos caiçaras da Ilha do Cardoso, pela força, coragem e sabedoria.

Que continuem resistindo. 


\section{AGRADECIMENTOS}

Ao meu orientador, Prof. Dr. Sidnei Raimundo, por ter aceitado me guiar no percurso da minha pesquisa. Seu conhecimento e experiência no mundo das unidades de conservação foram muito inspiradores. Muito obrigada pelo voto de confiança.

Ao gestor do Parque Estadual da Ilha do Cardoso, Edison Nascimento e aos funcionários passados e atuais do parque, por todas as informações repassadas e por toda a abertura durante a pesquisa.

Aos conselheiros do Conselho Gestor do Parque Estadual da Ilha do Cardoso, por abrirem as portas para que eu pudesse participar das reuniões e me fornecerem informações e percepções importantes para a pesquisa.

Aos queridos caiçaras da Ilha do Cardoso, que colaboram com as informações, registros e memórias fundamentais para a execução da pesquisa. A força de vocês foi a inspiração para o trabalho. Agradeço especialmente as comunidades do Marujá, da Enseada da Baleia, do Itacuruçá e Pereirinha, por me receberam tão gentilmente.

Ao Prof. Dr. Luiz Carlos Beduschi Filho e ao Prof. Dr. Rodrigo Constante Martins, pelas preciosas dicas e sugestões durante a banca de qualificação.

Aos amigos do Grupo de Pesquisa Territorialidades, Políticas Públicas e Conflitos na Conservação do Patrimônio, pelas discussões, viagens, ideias, sonhos e planos. 0 mestrado com vocês foi muito mais divertido! Super obrigada Juliana, Alessandra, Denise, Thalita, Paulo, Fabrício e Solange.

Ao cumpadre Carlos Padeiro, pela revisão dos textos.

Aos meus pais, Hilton e Neuza, pelo apoio em todos os momentos. Por todo o amor e carinho, e por terem estimulado em mim a paixão pelos estudos. Obrigada por tudo.

Ao meu irmão Felipe, que sempre está comigo, e ao meu irmão de coração Ewerton, por todo o apoio.

Ao meu amor, companheiro e melhor amigo Rafa, pelo apoio incondicional, por toda a paciência, pelas inúmeras horas e finais de semana "perdidos". Por estar ao meu lado nos piores e melhores momentos. Te amo! 
"Digo: o real não está na saída nem na chegada: ele se dispõe para a gente é no meio da travessia" João Guimarães Rosa 


\section{RESUMO}

VALLE, Paula Fernanda do. Conflitos e possibilidades da participação de comunidades locais na gestão do Parque Estadual da Ilha do Cardoso, São Paulo. 2016. 191 f. Dissertação (Mestrado em Ciências) - Escola de Artes, Ciências e Humanidades, Universidade de São Paulo, São Paulo, 2016.

O histórico de criação das unidades de conservação de proteção integral no Estado de São Paulo, a exemplo dos parques estaduais, é marcado pela imposição de áreas protegidas em muitos locais ocupados por comunidades tradicionais, causando inúmeros conflitos pela posse de terra. A gestão de tais áreas apresenta grandes desafios, tanto no que se refere à conservação da natureza quanto ao desenvolvimento e sobrevivência das comunidades. Se por um lado, de acordo com a lei, as comunidades devem ter seu modo de vida assegurados (BRASIL, 2000), ao menos enquanto não sejam realocados, por outro lado, essas comunidades em geral possuem poucos direitos reconhecidos. Estudos realizados no mundo todo têm comprovado as possibilidades de se aliar natureza e comunidades e, sobretudo, as possibilidades de inserção das comunidades na gestão destes espaços naturais. O Parque Estadual da Ilha do Cardoso apresenta um histórico de referência no Estado quando se trata de gestão participativa. No entanto, ainda hoje, as comunidades lutam para garantir seus direitos, principalmente em relação à terra. 0 presente estudo lança luz ao conselho gestor do Parque Estadual da Ilha do Cardoso como importante ferramenta de inserção das comunidades locais na gestão do parque e debruça-se na análise da participação de quatro comunidades caiçaras inseridas no seu interior: Marujá, Enseada da Baleia, Pereirinha e Itacuruçá. Através do modelo de análise Institutional Analysis and Development Framework - IAD, desenvolvido por Ostrom (1990), foi possível compreender o funcionamento do conselho gestor, bem como a influência dos arranjos institucionais das comunidades nos acordos formais e informais desenvolvidos entre comunidades e gestão em anos de relacionamento. Ainda que, legalmente, seja apenas consultivo, o conselho apresenta-se hoje como importante espaço de interação entre os atores e de inclusão das comunidades em alguns aspectos que envolvem a gestão do parque.

Palavras-chave: unidade de conservação, comunidades tradicionais, gestão participativa, conselho gestor, arranjos institucionais, Ilha do Cardoso. 


\begin{abstract}
VALLE, Paula Fernanda do. Conflicts and possibilities of the participation of local communities in Ilha do Cardoso State Park management, São Paulo. 2016. $191 \mathrm{f}$. Dissertation (Master of Science) - School of Arts, Sciences and Humanities, University of São Paulo, São Paulo, 2016.

The creation of strict-use protected areas in São Paulo State, for instance state parks, is marked by the imposition of protected areas in places that were once occupied by traditional communities, causing lots of conflicts for land possession. The management of these areas is a great challenge for the conservation of nature and also for the development and survival of the communities. According to the Brazilian law (BRASIL, 2000) the way of life of these communities must be guaranteed, at least while they are not reallocated. However, at the same time, these communities have only few recognized rights. Research conducted all over the world has proven that the possibilities of combining nature and communities and above all the possibilities of including the communities in the management of those protected areas. The Ilha do Cardoso State Park presents a historic reference concerning participative management. However, nowadays, communities still fight to ensure their rights, especially concerning land possession. The present study focuses on the managing council as an important way of including the local communities in the parks management. It also includes the analysis of the participation of four traditional communities located inside the park's area: Marujá, Enseada da Baleia, Pereirinha and Itacuruçá. Based on the framework developed by Ostrom (1990), Institutional Analysis and Development Framework - IAD, it was possible to comprehend how the managing council works, and the influence of the institutional arrangements of the communities on formal and informal arrangements developed between managers and communities through years of relations. Although the council is legally only advisory, it represents an important place of interaction between the actors involved and the inclusion of communities in some aspects that involve the management of the park.
\end{abstract}

Keywords: protected area, traditional communities, participative management, managing council, institutional arrangements, Ilha do Cardoso. 


\section{Lista de Figuras}

Figura 1 - Mapa de Localização do Parque Estadual da Ilha do Cardoso no Sudeste do Brasil...... 19

Figura 2 - Comunidades do Parque Estadual da Ilha do Cardoso ........................................................... 20

Figura 3 - Comunidades Analisadas no Parque Estadual da Ilha do Cardoso.......................................26

Figura 4 - Parte da Comunidade do Marujá, junto ao píer de chegada à comunidade ...................... 27

Figura 5 - Vista parcial da Praia do Itacuruçá, Comunidade do Itacuruçá ........................................... 29

Figura 6 - Chegada da Pesca, Comunidade Enseada da Baleia .................................................................. 30

Figura 7 - Arcabouço para Análise Institucional, conforme o IAD Framework .................................. 77

Figura 8 - Modelo de Análise: Adaptado de Institutional Analysis and Development Framework...

Figura 9 - Planta do Loteamento Parque Marujá - II ................................................................................ 87

Figura 10 - Processo da salga do peixe pelas mulheres da Enseada da Baleia..................................106

Figura 11 - Casas destruídas após acidente com embarcação na Enseada da Baleia. ......................109

Figura 12 - Reunião do Conselho Gestor na base do PEIC, em Cananéia.............................................140

Figura 13 - Linha do tempo da gestão do PEIC …………………………...........................................153

Figura 14 - Mapa do zoneamento do Parque Estadual da Ilha do Cardoso ........................................159 


\section{Lista de Quadros}

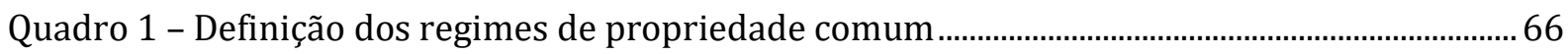

Quadro 2 - Níveis de tomada de decisão, de acordo com o IAD............................................................... 75

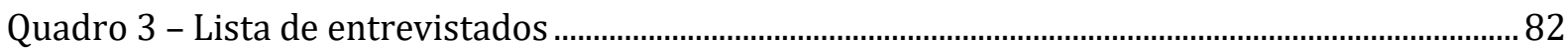

Quadro 4 - Composição do Conselho Gestor do PEIC - 2014/2016 …………...................................132

Quadro 5 - Quadro resumido das recomendações para uma instituição robusta............................157

Quadro 6 - Zoneamento do PEIC, de acordo com o Plano de Manejo.....................................................158 


\section{Lista de Abreviaturas e Siglas}

ASSESCA Associação das Escunas de Cananéia

AMEB Associação dos Moradores da Enseada da Baleia

AMOAMCA Associação dos Monitores Ambientais de Cananéia

AMOIP Associação dos Moradores do Itacuruçá e Pereirinha

BID Banco Interamericano de Desenvolvimento

CT Câmara Temática

CEPARNIC Centro de Pesquisas Aplicadas em Recursos Naturais da Ilha do Cardoso

CONSEMA Conselho Estadual do Meio Ambiente

CG Conselho Gestor

CDB Convenção da Diversidade Biológica

Fundação Florestal - Fundação para a Conservação e a Produção Florestal

FF do Estado de São Paulo

FEHIDRO Fundo Estadual de Recursos Hídricos

GT Grupo de Trabalho

IBAMA Instituto Brasileiro do Meio Ambiente e dos Recursos Naturais Renováveis

ICMBIO Instituto Chico Mendes de Conservação da Biodiversidade

IF Instituto Florestal

IUCN International Union for Conservation of Nature

MMA Ministério do Meio Ambiente

MPF Ministério Público Federal

ONG Organização Não Governamental

PEIC Parque Estadual da Ilha do Cardoso

PGA Plano de Gestão Ambiental

PL Projeto de Lei

PPMA Projeto de Preservação da Mata Atlântica

SMA Secretaria de Meio Ambiente do Estado de São Paulo

SIEFLOR Sistema Estadual de Florestas

SNUC Sistema Nacional de Unidades de Conservação

UC Unidade de Conservação

USP Universidade de São Paulo 


\section{SUMÁRIO}

INTRODUÇÃO

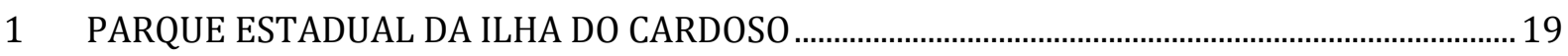

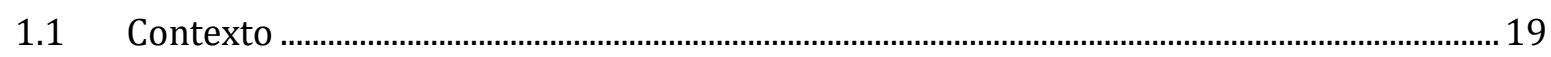

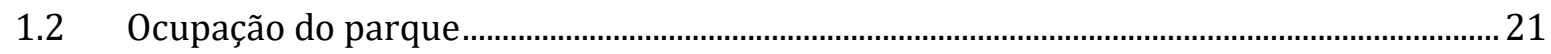

1.3 Histórico de gestão do PEIC ……………............................................................................... 22

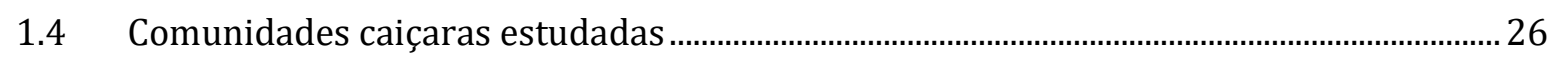

2 ABORDAGEM TEÓRICO CONCEITUAL........................................................................................... 32

2.1 Contextualizando o conflito: unidades de conservação, território e comunidades

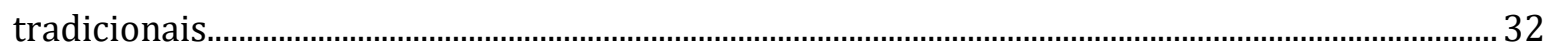

2.1.1 O surgimento do conflito: o movimento ambiental e a criação das unidades de conservação.

2.1.2 Explicitando o conflito - a justiça ambiental e a importância de aliar o natural com o social 38

2.1.3 O conflito para as comunidades caiçaras. 44

2.2 Participação e políticas públicas voltadas para Unidades de Conservação no Estado de São Paulo. .. .47

2.2.1 A participação nas Unidades de Conservação do Estado de São Paulo ....................... 50

2.2.2 E como funcionam os conselhos gestores de parques?.................................................... 57

2.3 Gestão dos recursos naturais e desenho institucional - um outro modo de gerir os recursos.

2.3.1 Ação coletiva e Arranjos Institucionais .......................................................................... 67

2.3.2 Modelo de análise: Institutional Analysis and Development Framework / IAD ..... 72

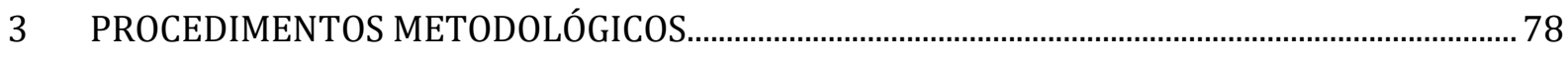

3.1 Definição do modelo de análise ................................................................................................... 79

3.2 Pesquisa documental e bibliográfica................................................................................... 80

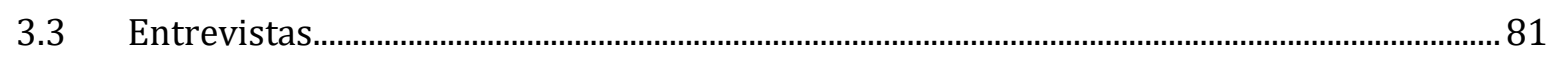

3.4 Participação nas reuniões do Conselho Gestor do PEIC .......................................................... 83

3.5 Visitas às comunidades .................................................................................................................. 83

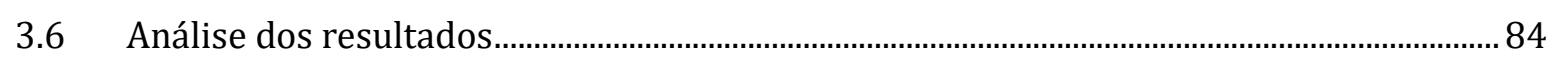

4 PARTICIPAÇÃO DAS COMUNIDADES NA GESTÃO DO PARQUE ESTADUAL DA ILHA DO

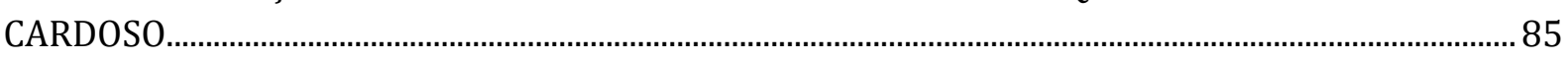

4.1 Arranjos institucionais das comunidades ......................................................................... 85

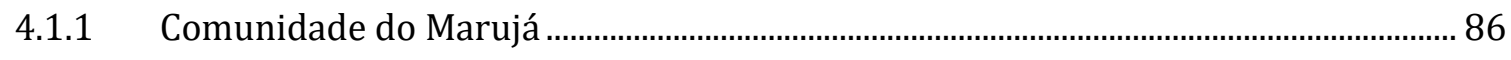

4.1.2 Comunidade da Enseada da Baleia ................................................................................103

4.1.3 Comunidade do Itacuruçá/Pereirinha .........................................................................118

4.2 Conselho Gestor do PEIC ....................................................................................................128

4.2.1 Surgimento do conselho gestor do PEIC ...................................................................128 


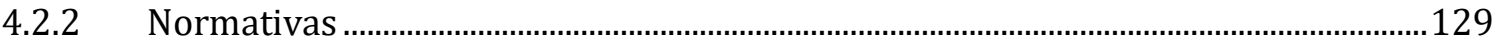

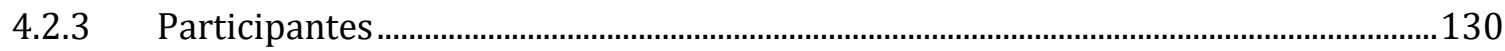

4.3 Regras em uso no PEIC e no conselho...................................................................................134

4.4 Como funciona o conselho - Interações e decisões................................................................139

4.4.1 Definição das reuniões..........................................................................................................139

4.4.2 Compreensão dos assuntos discutidos .........................................................................141

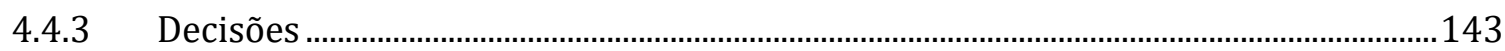

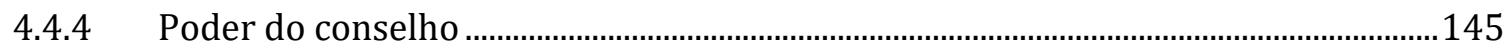

4.4.5 Dificuldades e desafios do conselho..............................................................................147

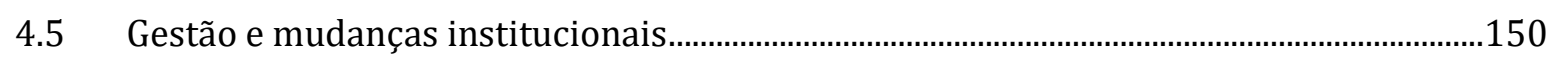

4.6 Análise da robustez institucional do conselho, com base nos critérios de Ostrom .......156

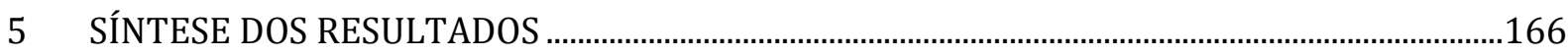

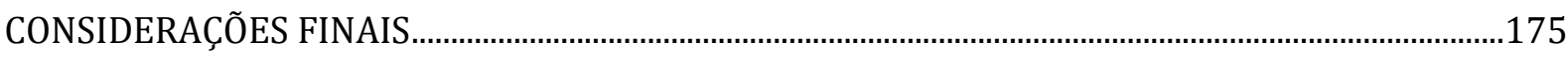

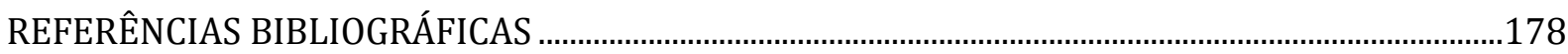

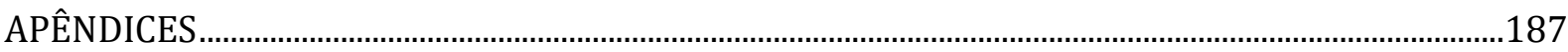

Apêndice A - Instrumento de coleta de informações semistruturado ................................................187

Apêndice B - Termo de Consentimento Livre e Esclarecido ......................................................................191 


\section{INTRODUÇÃo}

As Unidades de Conservação (UCs) do Estado de São Paulo apresentam inúmeros conflitos em sua gestão, relacionados à conservação da biodiversidade e aos interesses das comunidades locais que habitam seu interior ou entorno. Tais conflitos estão associados ao modelo de unidade de conservação adotado no Brasil, reflexo do modelo norte-americano de criação de unidades de conservação, que considera áreas naturais como espaços que devem ser protegidos da ação humana, e voltados apenas para a contemplação, como locais de conservação de uma natureza idealizada (intocada ou selvagem) e nos quais a sociedade é excluída, excetuando-se as atividades de visitação (DIEGUES, 1988, 1994, 2001).

Seguindo os princípios desse modelo, foram instituídas no Estado de São Paulo (assim como no restante do país) diversas unidades de conservação em áreas ocupadas por comunidades. Territórios antes ocupados por comunidades inteiras acabaram sendo sobrepostos por áreas protegidas, causando inúmeros conflitos pela posse de terra. Em muitos casos, as comunidades viviam sob uma lógica de reprodução de sua cultura diferente, sem necessidade de acumulação, como no modo de produção capitalista. Diversos autores defendem, inclusive, que em muitas dessas áreas a conservação dos recursos naturais só foi possível por conta da relação que tais comunidades estabeleceram com o meio natural.

Após a instituição dessas unidades de conservação, surgiram inúmeros conflitos entre o poder público e as comunidades, que, paulatinamente, acabaram perdendo qualquer direito sobre seus territórios e foram obrigadas a deixarem suas localidades ou a viverem de acordo com as regras estabelecidas pelo poder público. Muitas dessas comunidades resistiram, de diversas maneiras, e continuam até hoje na luta pela conquista de seus direitos.

Passados quase 80 anos desde a criação da primeira unidade de conservação no Brasil, o Parque Nacional de Itatiaia, observam-se alguns avanços no que diz respeito à inserção das comunidades no processo de gestão das unidades de conservação. 
Tem-se tornado cada vez mais comuns as reflexões a respeito da inserção das comunidades locais na gestão desses espaços naturais. Ampliou-se o número de estudos sobre participação e outros princípios de governança em unidades de conservação no meio acadêmico. E esses estudos têm sido considerados pelo poder público, ainda que de maneira incipiente. Inúmeros autores, a exemplo de Diegues (1986, 1994, 2001), Irving (2002, 2004), Ferreira (2002) e Simões (2010), defendem que as comunidades tradicionais inseridas no interior de unidades de conservação devem permanecer em seus territórios, e ainda devem ser incluídas no processo de gestão dessas áreas protegidas, de maneira que se alcance não apenas a conservação ambiental das áreas, mas também o desenvolvimento socioambiental dessas comunidades. Outros autores vão além, a exemplo de Ostrom (1990), que defende as possibilidades de gestão de recursos comuns pelas próprias comunidades. Por meio de estudos de caso concretos e, embora o tema da conservação não fosse seu objetivo central, essa autora provou que as próprias comunidades conseguiram gerenciar regimes de propriedade coletiva ou propriedades comunais com regras de manejo próprias.

Embora muitos estudos apontem que a participação social na gestão de unidades de conservação é premissa fundamental para que se garanta o uso sustentável dos recursos naturais, alcançar uma gestão participativa envolve inúmeros desafios que devem ser considerados no processo de planejamento e gestão das unidades de conservação, tanto por parte do órgão gestor quanto por parte das próprias comunidades locais.

O Parque Estadual da Ilha do Cardoso (PEIC), no litoral sul de São Paulo, é considerado como modelo de referência nesse Estado quando se trata de gestão participativa. 0 parque conta com oito comunidades tradicionais caiçaras que residem nos limites da unidade de conservação desde sua implantação, em 1962. 0 grande marco para o parque, e o que o faz ser considerado como modelo de referência, está relacionado à elaboração do seu Plano de Manejo no final da década de 1990. 0 plano foi elaborado de maneira participativa e contou com a colaboração de todas as comunidades residentes na ilha, apresentando um modelo de inclusão inédito até então. Na mesma época também foi criado o Comitê de Apoio à Gestão do PEIC, que viria a se tornar o conselho gestor do parque. Trata-se de dois instrumentos de suma importância, atualmente, no âmbito da participação em unidades de conservação, previstos inclusive em forma de lei. 
Diversos foram os elementos que contribuíram para que esse processo ocorresse no Parque Estadual da Ilha do Cardoso, a exemplo da organização comunitária existente em uma das comunidades, a presença de lideranças locais fortes e a presença de um gestor que era aberto ao diálogo e aos processos participativos (RODRIGUES, 2001, MARINHO, 2013).

Passados quase 15 anos desde a aprovação do Plano de Manejo do parque e 18 anos desde a criação do Comitê de Apoio à Gestão, muitas "águas já rolaram", tanto no campo das políticas públicas voltadas para unidades de conservação, quanto no que se refere à organização interna das comunidades e à própria organização interna da Secretaria de Meio Ambiente do Estado de São Paulo.

As comunidades estão mais organizadas, por meio de associações comunitárias, enquanto a gestão da área pela Fundação Florestal acompanhou diversas trocas de gestores na última década. No entanto, o conselho gestor do parque continua sendo um espaço de interação entre comunidades, órgão responsável (Fundação Florestal) e demais atores que fazem parte da gestão do parque.

Tendo em vista a importância da participação das comunidades na gestão de unidades de conservação, este estudo lança luz sobre o conselho gestor como ferramenta fundamental de inserção das comunidades na gestão do parque e buscou compreender os elementos que possibilitam essa participação, tanto no âmbito do desenho institucional do conselho, quanto no âmbito da organização interna das comunidades.

Assim, esta dissertação teve como objetivo geral analisar as possibilidades e conflitos da participação de comunidades locais na gestão de parque estaduais, tendo como base o Parque Estadual da Ilha do Cardoso e os caiçaras de quatro comunidades que habitam seu interior.

E os objetivos específicos foram:

- Analisar o papel dos arranjos institucionais das comunidades como elementos de participação na gestão do parque;

- Analisar a participação das comunidades no conselho gestor e sua influência nos processos decisórios; 
- Analisar a robustez institucional do conselho gestor e sua importância na resolução dos conflitos com as comunidades.

A escolha do Parque Estadual da Ilha do Cardoso se deu justamente por ser um modelo de referência em gestão participativa, principalmente no que se refere à comunidade do Marujá. Referência também em gestão comunitária, o histórico dessa comunidade se confunde com o histórico do parque em diversos momentos. Embora sua atuação tenha sido fundamental, compreender a participação das outras comunidades é importante para entender os conflitos e possibilidades de participação das comunidades como um todo na gestão do parque. Por este motivo, optou-se por focar as análises na participação de mais três comunidades na gestão do PEIC, de maneira a compreender os diferentes arranjos que compõem cada uma das comunidades e como tais arranjos influenciam, ou não, sua participação no âmbito da gestão do parque e do conselho gestor.

Para o alcance dos objetivos propostos, optou-se pela abordagem qualitativa, a partir de uma análise institucional. Com base no modelo de análise desenvolvido por Elinor Ostrom (1990), o Institutional Analysis and Development Framework (IAD), as análises se debruçaram na compreensão dos seguintes elementos: arranjos institucionais de cada uma das comunidades; funcionamento do conselho gestor; regras em uso pelos atores; e análise da robustez do conselho gestor. Pretendeu-se analisar os arranjos institucionais presentes em cada uma das comunidades escolhidas, bem como sua influência nos diferentes níveis de participação das comunidades no conselho gestor.

A abordagem institucional com foco no conselho gestor foi escolhida pela importância desse espaço no contexto da gestão do parque e da participação das comunidades. Os dados foram coletados por meio de entrevistas com atores-chave, observação não participante nas reuniões do conselho gestor e visita às comunidades analisadas.

Os resultados desta pesquisa visam contribuir para uma gestão mais efetiva das unidades de conservação brasileiras, com envolvimento das comunidades nos processos de tomada de decisão, minimizando os conflitos existentes nessas áreas.

Esta dissertação está organizada em cinco capítulos, além da introdução e das considerações finais. 
O capítulo 1 apresenta o histórico do Parque Estadual da Ilha do Cardoso, além de uma breve introdução das comunidades analisadas na pesquisa. Expõe em linhas gerais os caminhos que levaram o Parque Estadual da Ilha do Cardoso a ser considerado modelo de referência em gestão participativa. 0 capítulo 2 apresenta os referenciais teóricos utilizados na pesquisa, com foco em três pilares: conflito entre unidades de conservação e comunidades tradicionais; participação em unidades de conservação e conselhos gestores; modelo de análise para gestão de recursos de uso comum, proposto por Ostrom (1990). 0 capítulo 3 apresenta os procedimentos metodológicos utilizados na pesquisa. 0 capítulo 4 contempla as análises feitas a partir do modelo de análise, com foco nos arranjos institucionais das comunidades; no conselho gestor e seu funcionamento; nas regras em uso no parque e no conselho gestor; na gestão e nos impactos das mudanças institucionais. Ao final, apresenta uma análise da robustez do conselho gestor. Por fim, o capítulo 5 apresenta uma síntese dos principais resultados obtidos frente aos objetivos propostos pela pesquisa. 


\section{PARQUE ESTADUAL DA ILHA DO CARDOSO}

\subsection{Contexto}

O Parque Estadual da Ilha do Cardoso - PEIC - foi criado pela Secretaria de Estado do Meio Ambiente por meio do Decreto Estadual № 40.319, de 1962, em função da existência de sambaquis na região (MENDONÇA, 2000). A região ainda conta com remanescentes de Mata Atlântica preservados, com uma biodiversidade local que se reflete nos diversos tipos de ecossistemas que podem ser encontrados na região: praias, manguezais, estuário, rios, restinga e florestas.

O PEIC está localizado no município de Cananéia, litoral sul do estado de São Paulo, na divisa com o estado do Paraná. A ilha é separada do continente pelo canal do Ararapira e pela Baia do Trapandré. Está inserido no complexo estuarino-lagunar de Iguapé/Cananéia na região do Baixo Vale do Ribeira, que se estende pelo litoral entre Peruíbe (SP) e Paranaguá (PR), sendo considerado um dos maiores criadouros de espécies marinhas do Atlântico Sul. Foi reconhecido pela UNESCO, em 1992, como Zona Núcleo da Reserva da Biosfera e, em 1999, como Sítio do Patrimônio Mundial Natural (SÃO PAULO, 2001).

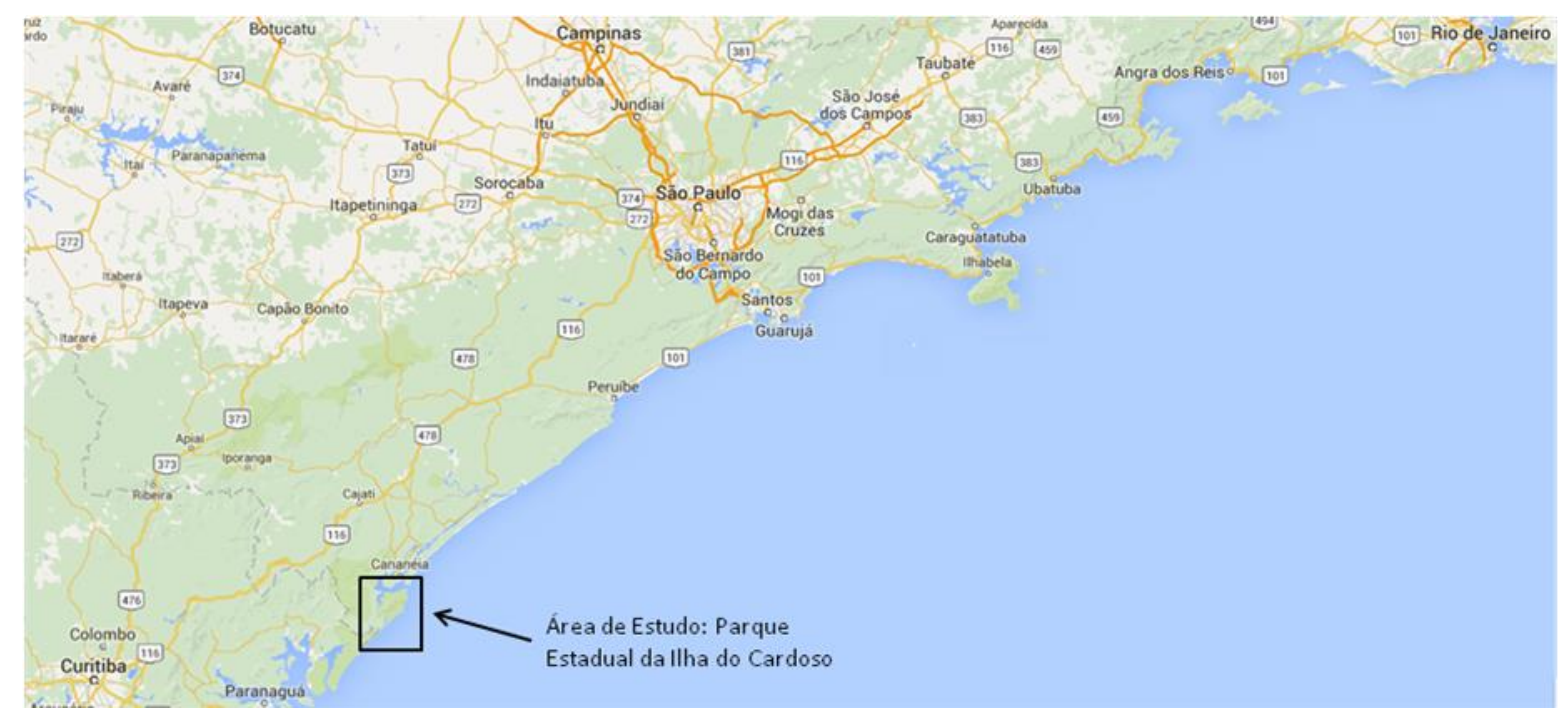

Figura 1 - Mapa de Localização do Parque Estadual da Ilha do Cardoso no Sudeste do Brasil. Fonte: Adaptado de Google Maps, 2016. 
O PEIC possui atualmente oito comunidades, habitadas em sua maioria por comunidades tradicionais caiçaras: Marujá, Itacuruçá, Pereirinha, Enseada da Baleia, Vila Rápida, Pontal do Leste, Cambriú e Foles. Conta ainda com alguns sítios na ilha e uma comunidade de etnia Guarani-Mbya, que se estabeleceu no parque em 1992.

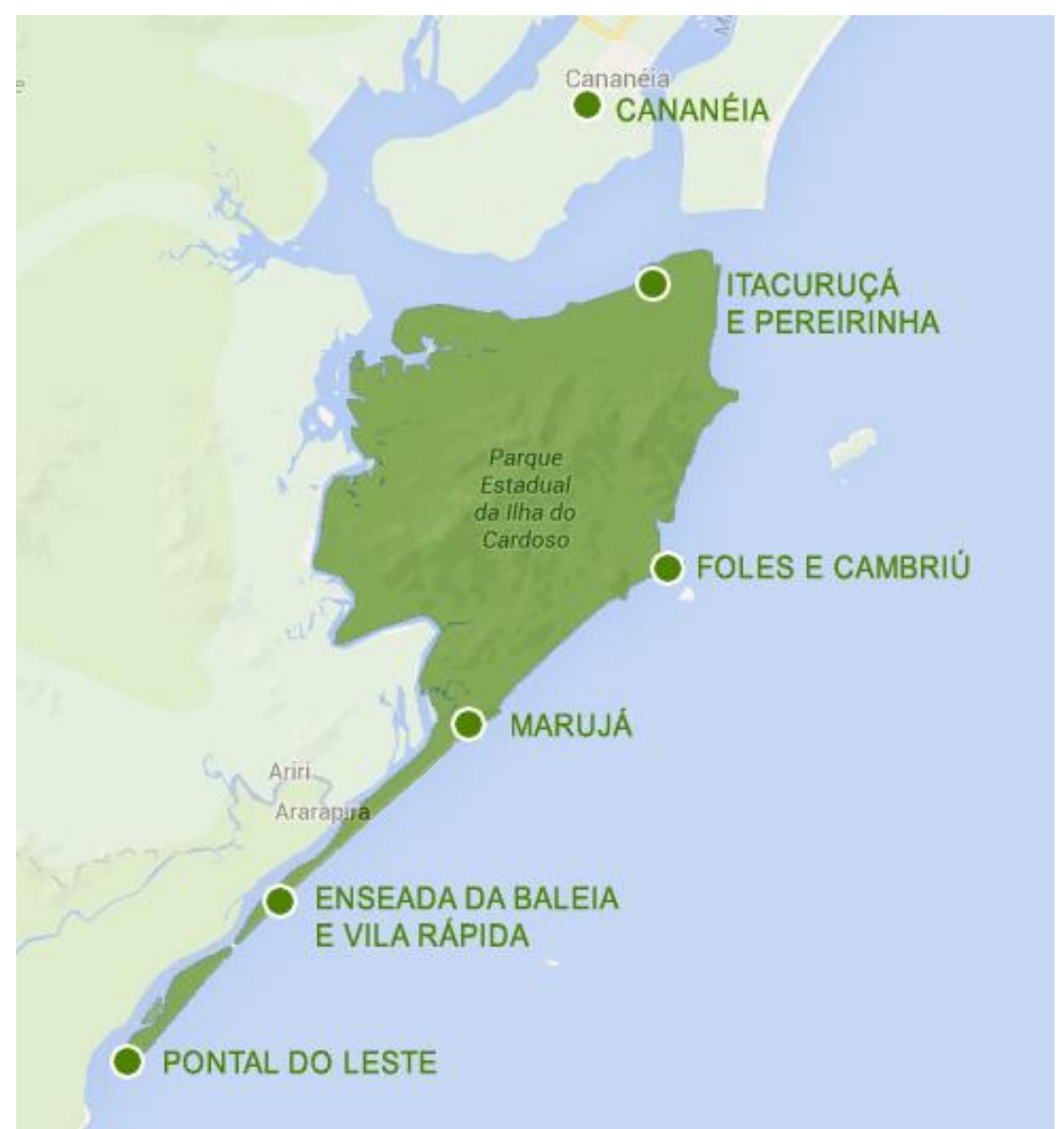

Figura 2 - Comunidades do Parque Estadual da Ilha do Cardoso Fonte: Adaptado de Google Earth, 2016.

O turismo se destaca como uma das principais atividades econômicas atuais para as comunidades do PEIC, juntamente com as a pesca. Destacam-se, entre os principais serviços que envolvem o turismo nas comunidades, os meios de hospedagem, que abrangem campings, pequenas pousadas e hospedarias familiares; estabelecimentos de alimentação, abrangendo bares e pequenos restaurantes; serviços de transporte, abrangendo pequenas embarcações para passeio e traslado; e serviços de monitoria.

De acordo com dados da Fundação Florestal, o PEIC recebeu, em 2013, 41.350 visitantes (CAMPOLIM et al, 2015), incluindo turistas convencionais, pesquisadores e estudantes. 
Durante os períodos de baixa estação, as visitas técnicas de escolas têm especial importância, colaborando para diminuir os impactos da sazonalidade.

\subsection{Ocupação do parque}

A região tem um histórico marcado por diversos acontecimentos. Os primeiros habitantes humanos da Ilha do Cardoso foram os chamados "homens dos sambaquis", que deixaram vestígios de ocupação pré-histórica, numerosos na faixa litorânea paulista, em especial na região de Cananéia, Ilha Comprida e Ilha do Cardoso (SÃO PAULO, 2001). Antes da chegada dos colonizadores europeus, a região era habitada pelos índios tupiniquins e carijós. Durante o séc. XVI, com a chegada dos europeus, a região de Iguape e Cananéia foi palco de diversos acontecimentos da história do Brasil.

A construção da BR-116, em 1956, conectando São Paulo a Curitiba, foi um marco para a região do Vale do Ribeira, já que desencadeou, de um lado, um processo de urbanização da região, e de outro um processo de intensa especulação imobiliária com a busca de áreas de lazer. Como em todo o litoral paulista, a região da Ilha do Cardoso, na década de 1960, encontrava-se dividida em loteamentos, a exemplo dos loteamentos Balneários Parque Marujá e Lindomar, localizados onde hoje estão as comunidades do Marujá e do Itacuruçá, respectivamente. A especulação imobiliária e o turismo exerceram grande pressão sobre terras de comunidades caiçaras, em especial aquelas que ainda registravam grande beleza cênica e potencial para atrair turistas nesse período (SÃO PAULO, 2001). A instituição do parque, ainda que tenha causado inúmeros conflitos locais, acaba por barrar esse processo de especulação imobiliária e de desenvolvimento do turismo de massa, característico de inúmeras regiões litorâneas no estado de São Paulo (MARINHO, 2013; SIMÕES, 2010; RAIMUNDO, 2007).

$\mathrm{Na}$ época em que a área foi decretada parque estadual, habitavam o local famílias de caiçaras que ocupavam principalmente as terras de restinga, ao sul da ilha, e as margens litorâneas, ao norte. Pouco antes, teve início um processo de loteamento de um condomínio de luxo na ilha, época em que alguns habitantes não caiçaras acabaram se instalando na região. Se por um lado o decreto de criação do parque acaba por barrar a 
continuação desse loteamento, por outro acaba também por afetar as comunidades caiçaras que habitavam a ilha, causando inúmeros conflitos. Muitos foram expulsos ou acabaram saindo da ilha, por conta das proibições impostas, e os que permaneceram passaram a viver exclusivamente da pesca e, ilegalmente, de outras atividades, como a caça, a roça e o extrativismo (BECCATO, 2004).

A implantação do parque, de fato, só teve início com a construção do CEPARNIC (Centro de Pesquisas Aplicadas em Recursos Naturais da Ilha do Cardoso), em 1972, na comunidade do Itacuruçá/Pereirinha, que daria origem, posteriormente, ao Núcleo Perequê. 0 centro era controlado inicialmente pela Secretaria de Estado de Agricultura e Abastecimento (SAA), sendo transferido para a administração da Secretaria de Estado de Meio Ambiente (SMA) apenas na década de 1990.

\subsection{Histórico de gestão do PEIC}

À época da criação do PEIC, a região passava por um intenso processo de especulação imobiliária, tanto por se tratar de uma área com inúmeras belezas naturais, quanto por ser fronteira de ocupação turística na lógica do capital imobiliário. Se por um lado a criação do parque foi responsável por barrar essa especulação, por outro lado o parque também foi responsável por gerar inúmeros conflitos com os moradores tradicionais da ilha, formados em sua maioria por populações caiçaras que já tinham um histórico de vivência na região, mas que tiverem seus direitos limitados por estarem em uma área em que o poder público delimitou como unidade de conservação.

O PEIC tem um histórico de participação que se apresenta hoje como referência no tocante à abordagem participativa na gestão de UCs. Rodrigues, em sua tese de doutoramento, analisa os limites do consenso e da participação no PEIC e conclui que três aspectos foram decisivos para o êxito da abordagem participativa no PEIC: a postura do gestor, o envolvimento dos moradores, propiciado pelas reuniões itinerantes, e a experiência dos gestores e membros que participaram do processo na própria região (RODRIGUES, 2001). 
Primeiramente, é preciso destacar o processo de organização da comunidade do Marujá como importante aspecto influenciador e motivador no contexto do parque.

O Marujá organizou, em 1993, o seu Plano de Gestão Comunitária, sob a demanda da própria comunidade e de suas principais lideranças, frente ao crescimento desordenado do turismo na região e aos impactos negativos que a comunidade já sentia desde aquela época. Tratava-se, conforme afirma Marinho (2013), de um documento informal, que determinava regras e normas de organização e interação com agentes externos à comunidade. A elaboração de um plano de gestão pela própria comunidade denota o caráter singular da comunidade do Marujá, que reflete sua característica marcante de organização comunitária e empoderamento, consequência principalmente de suas lideranças fortes e conscientes do poder comunitário. Esse plano elaborado pela comunidade, segundo o autor, serviu de base de negociação da comunidade com o parque durante a década de 1990, sendo posteriormente utilizado como subsídio para a elaboração do Plano de Gestão Ambiental e do Plano de Manejo.

O PEIC foi uma das unidades contempladas pelo Projeto de Preservação da Mata Atlântica (PPMA) ${ }^{1}$, tendo sido um dos pioneiros na elaboração do Plano de Manejo no âmbito das UCs paulistas. 0 Plano de Gestão Ambiental, fases 1 e 2, foi elaborado entre os anos de 1997 e 1998 e serviu de base para o Plano de Manejo, aprovado pelo Conselho Estadual de Meio Ambiente (CONSEMA) em 2001.

Uma das características mais marcantes da elaboração do plano foi o caráter participativo em todas as suas fases de execução. Ainda que a participação fosse um dos pressupostos do PPMA, a sua efetivação não se deu de maneira uniforme em todas as nove UCs contempladas pelo projeto.

De maneira geral, as ações do Plano de Gestão contaram com duas fases. Na primeira, foram realizados um diagnóstico e uma análise da área a partir de dados secundários (MARETTI et al 1997). No caso do PEIC, parte dos dados vieram, em sua maioria, do Plano de Gestão Comunitária elaborado pela Comunidade do Marujá. A segunda fase

\footnotetext{
1 O PPMA - Projeto de Preservação da Mata Atlântica foi desenvolvido pela Secretaria de Estado de Meio Ambiente de São Paulo, entre 1997 e 1998, com financiamento do Banco KFW. Em linhas gerais, o projeto contemplava a elaboração de Planos de Gestão Ambiental em nove unidades de conservação do Estado de São Paulo.
} 
correspondeu à implantação da fase 1, que deu origem ao Plano de Manejo propriamente dito.

A Matriz de Planejamento do plano foi elaborada por meio de oficinas de planejamento, realizadas com órgãos públicos, organizações do terceiro setor, sociedade civil, pesquisadores e comunidades tradicionais. Rodrigues (2001) aponta que, como fruto das oficinas, foram elaborados dois documentos: Resultado da deliberação da Oficina de Planejamento para o Uso e Ocupação do Solo no PEIC e Conceituação dos temas tratados na Oficina de Planejamento - Direitos da População Local. Segundo a autora, ambos representaram um marco histórico nas políticas públicas ambientais ao legitimarem a categoria "moradores tradicionais", que passou a "ser instrumentalizada para a questão identitária, estando diretamente ligada ao direito de permanência na ilha e de uso dos recursos naturais" (Rodrigues, 2001, p.72).

O documento mencionado apresentava definições claras de quem era "morador tradicional" e quem era "invasor", assim como quem teria direito ou não a permanecer na ilha e a delimitação das normas de ocupação humana nos limites do parque. De acordo com o plano, morador tradicional deveria apresentar as seguintes características:

- Chefe da família que reside, no mínimo, há 3 (três) gerações na Ilha do Cardoso;

- Desenvolvem atividades de baixa interferência no meio ambiente, caracterizadas pela pequena escala e baseadas no uso dos recursos renováveis;

- Tem conhecimento e domínio das técnicas tradicionais (pesca, agricultura e construção).

Nota-se que a participação dos moradores tradicionais nas oficinas de planejamento foi de fundamental importância para a garantia de seus direitos de permanência no parque. A partir do Plano de Manejo, as comunidades foram inseridas no zoneamento como Zona de Uso Intensivo e Extensivo, possibilitando, por exemplo, que pudessem desenvolver atividades de visitação pública e pequenos roçados. Observa-se que as zonas de uso intensivo e extensivo estão presentes no Roteiro Metodológico de Planejamento, elaborado pelo Instituto Brasileiro do Meio Ambiente e dos Recursos Naturais Renováveis - Ibama em 2002, que serviu como base para a elaboração de diversos planos de manejo no Brasil. No entanto, o Ibama não reconhece atividades de pequenos 
roçados, por exemplo, até mesmo nas zonas de uso intensivo, refletindo o caráter diferencial do Plano de Manejo do PEIC. Foi, dessa maneira, a estratégia que os elaboradores do plano (comunidades e técnicos do IF e FF) encontraram para garantir a permanência dos moradores tradicionais, executando atividades ligadas aos objetivos de um parque (o Uso Público) e as ligadas à subsistência das comunidades (roças e extrativismo), embasados pelo parágrafo $2^{\circ}$ do artigo $42^{\circ}$ do Sistema Nacional de Unidades de Conservação - SNUC².

0 Comitê de Apoio à Gestão da Ilha do Cardoso foi formado em 1998, também no âmbito do PPMA, como um embrião do que viria a ser o conselho gestor posteriormente. A criação do comitê pretendia democratizar a gestão dos parques estaduais que estavam contemplados pelo PPMA. A princípio, concedeu-se ao comitê o poder consultivo, mas, conforme indica Rodrigues (2001), o comitê tinha na prática um caráter deliberativo, diferentemente do que ocorria nos comitês das outras oito UCs abrangidas pelo PPMA. De acordo com a autora, esse aspecto só foi possível no PEIC por conta do gestor do parque que, na época, assumiu a coordenação do Comitê e incorporou uma abordagem participativa ao possibilitar que as decisões fossem tomadas coletivamente entre os membros do Comitê.

Durante sua gestão, as reuniões do Comitê eram itinerantes e aconteciam nas próprias comunidades tradicionais, o que facilitava a participação dos moradores, e fazia com que os próprios moradores se responsabilizassem pela logística de realização dos encontros. Se por um lado, todas as comunidades tinham a chance de serem ouvidas, por outro lado, os demais membros do Comitê tinham envolvimento direto com as diferentes realidades das comunidades do parque.

Por meio do histórico de seu processo de implantação, percebem-se as justificativas que fizeram do PEIC uma referência de gestão participativa. No entanto, desde a elaboração do Plano de Manejo, no final da década de 1990, muitas mudanças ocorreram, em especial no que diz respeito à gestão e à Secretaria de Meio Ambiente, a exemplo das inúmeras trocas de gestão e, consequentemente, de diálogo com as comunidades, que serão exploradas mais adiante.

\footnotetext{
${ }^{2}$ Sistema Nacional de Unidades de Conservação - SNUC, definido pela lei no9.985 de 2000.
} 


\subsection{Comunidades caiçaras estudadas}

Serão estudadas ao longo da pesquisa as quatro principais comunidades do Parque Estadual da Ilha da do Cardoso: Marujá, Itacuruçá, Pereirinha ${ }^{3}$ e Enseada da Baleia. A escolha pelo recorte de análise das quatro comunidades, entre as oito presentes na ilha, deu-se por conta de alguns critérios considerados essenciais para o alcance dos objetivos propostos: a organização institucional, o número de famílias e a participação no conselho gestor. A análise dos arranjos institucionais envolve compreender com certa profundidade como está organizada cada uma das comunidades, sendo o recorte fundamental para garantia de viabilidade de execução da proposta. Ademais, trata-se das três comunidades com maior participação no conselho gestor desde sua criação.

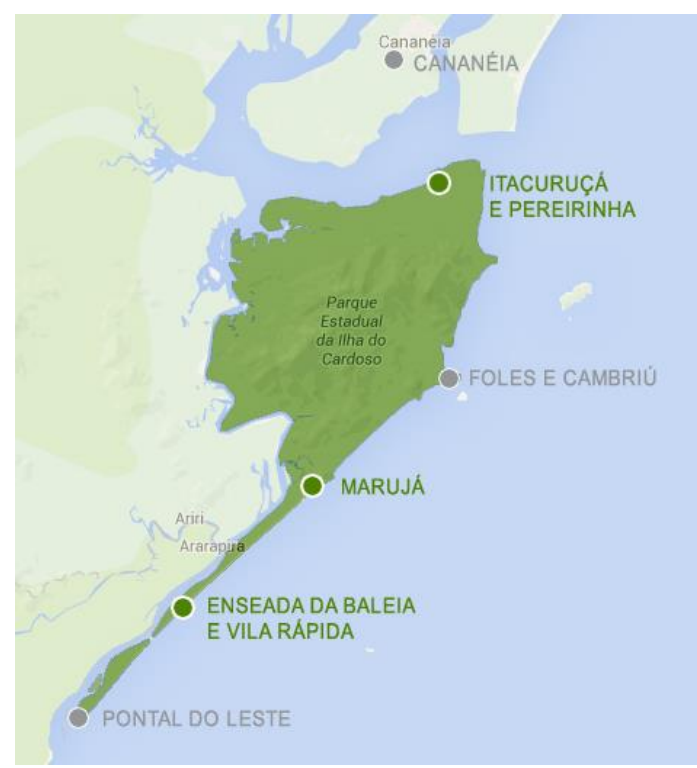

Figura 3 - Comunidades Analisadas no Parque Estadual da Ilha do Cardoso

Fonte: Adaptado de Google Earth, 2016.

Originalmente denominada Praia do Meio, a Comunidade do Marujá (vide Figura 4) está estabelecida no Núcleo Marujá do PEIC, sendo atualmente o maior núcleo habitacional do parque com aproximadamente 180 habitantes.

\footnotetext{
3 Trata-se de duas comunidades caiçaras muito próximas que estão organizadas em uma só associação, a AMOIP. Por conta dos arranjos institucionais presentes, serão tratadas em conjunto, como uma comunidade ao longo da pesquisa.
} 


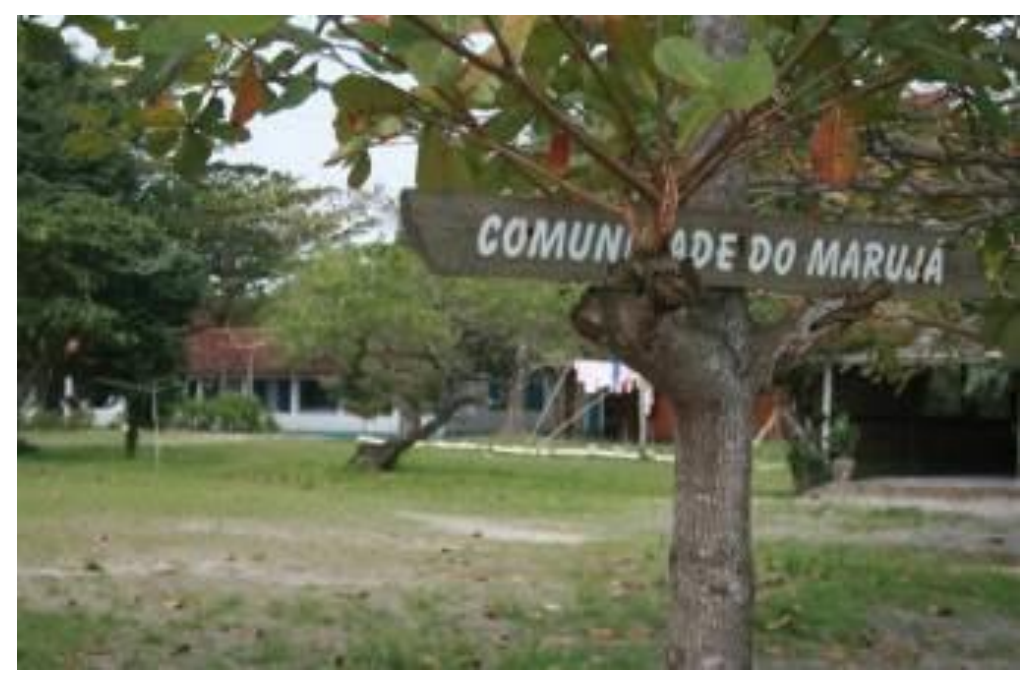

Figura 4 - Parte da Comunidade do Marujá, junto ao píer de chegada à comunidade

Fonte: Secretaria de Meio Ambiente, 2014.

A Associação dos Moradores do Marujá (AMOMAR) foi criada em 1998 e é responsável pela gestão e organização do turismo na comunidade. 0 acesso à comunidade se dá apenas por meio de pequenas embarcações, saindo da sede do município de Cananéia.

A comunidade dispõe de infraestrutura comunitária simples, contando com escola, centro comunitário, posto telefônico, posto de saúde e igreja católica. Conta ainda com um Núcleo de Visitação do Marujá, pertencente ao parque (Fundação Florestal), mas gerido pela AMOMAR. Contempla o maior número de famílias do parque, mas também concentra boa parte da infraestrutura disponível aos turistas.

O verão dos anos de 1997 e 1998 marca o início do ordenamento da visitação turística no parque, principalmente por conta dos esforços que vinham sendo empreendidos pela comunidade do Marujá, que já recebia um fluxo considerável de turistas na época. De acordo com Campolim, após o início desse processo de ordenamento do turismo, boa parte dos moradores tradicionais saiu beneficiado, na medida em que houve uma distribuição dos ganhos da atividade entre um número maior de moradores, e também foi proibida a exploração da atividade por moradores não tradicionais (CAMPOLIM, et al, 2008, p.222).

Rodrigues aponta que a atividade turística acabou por reforçar a ligação dos comunitários com a ilha, em especial no Marujá, mas também em menor escala na Enseada da Baleia, estimulando a participação dos moradores nos processos iniciados naquela época. De acordo com a autora, na medida em que uma parte considerável dos 
moradores dependia da renda do turismo durante a alta temporada, havia um estímulo maior para que os mesmos comparecessem às reuniões participativas do Comitê de Apoio à Gestão, que subsidiaram a elaboração do Plano de Manejo (RODRIGUES, 2001).

Principalmente durante o período do verão, a comunidade recebe um fluxo alto de turistas, sempre respeitando o limite estabelecido pelo Plano de Manejo, de aproximadamente 1.000 pessoas por dia (São Paulo, 2000). Esse cálculo foi feito durante o ordenamento da atividade turística, que coincide com a fase de elaboração do Plano de Manejo. 0 número limite de turistas na comunidade foi definido a partir do cálculo do número de leitos disponíveis na época, contemplando as áreas de camping, pousadas, hospedarias familiares e casas para aluguel (CAMPOLIM et al, 2008). Para este estudo não foram utilizadas metodologias mais tradicionais para o estudo de capacidade de carga, como as preconizadas por Cifuentes (1992), que consideram variáveis naturais e culturais. No caso específico do Marujá, foi considerada principalmente sua capacidade operacional de desenvolvimento da atividade turística, associada ao número de banheiros e quartos para atendimento do visitante.

Esse processo de ordenamento participativo da visitação pública na comunidade do Marujá foi responsável, direta ou indiretamente, por diversas conquistas da comunidade, de acordo com Campolim et al (2008).

- Implantação de coleta seletiva gerenciada pela comunidade;

- Implantação de sistema básico de esgoto;

- Melhorias da rede de captação e instalação de reservatórios, minimizando os problemas com água;

- Implantação de telhas de cerâmica nas residências;

- Controle populacional de animais domésticos (cachorros e gatos) e proibição de novos animais;

- Autonomia dos moradores no que se refere aos serviços turísticos (meios de hospedagem, restaurantes e transporte náutico);

- Posicionamento contrário aos ocupantes não tradicionais irregulares na ilha, culminando em ações de reintegração de posse pelo Estado e demolições de edificações irregulares;

- Valorização da cultura caiçara; 
- Distribuição dos benefícios do turismo por toda a comunidade;

- Central de reservas comunitária, através do telefone público administrado pela AMOMAR;

- Regras para o controle do barulho excessivo e horários máximo de som;

- Estabelecimento de regras de navegação e transporte náutico turístico.

Nota-se que o planejamento da atividade turística, com a participação da comunidade, resultou em inúmeros benefícios, que ultrapassam os limites da própria atividade turística em si, culminando em benefícios para a própria qualidade de vida dos moradores.

Por meio de acordos coletivos firmados durante anos de relação com a gestão do PEIC, a comunidade do Marujá, por meio da AMOMAR, conseguiu conquistar direitos não formais de gerenciamento da atividade turística local. Dessa forma, a própria comunidade é responsável por gerir a atividade turística no local.

A comunidade do Itacuruçá/Pereirinha é a que está mais próxima de Cananéia, a 6,5 km da cidade, na baía de Trapandé. Está estabelecida no Núcleo Perequê do PEIC (vide Figura 5). Em uma de suas extremidades é banhada pelo rio Perequê. A comunidade está organizada por meio da Associação dos Moradores de Itacuruçá e Pereirinha (AMOIP). É um dos menores núcleos habitacionais do parque, com apenas duas famílias residindo na ilha.

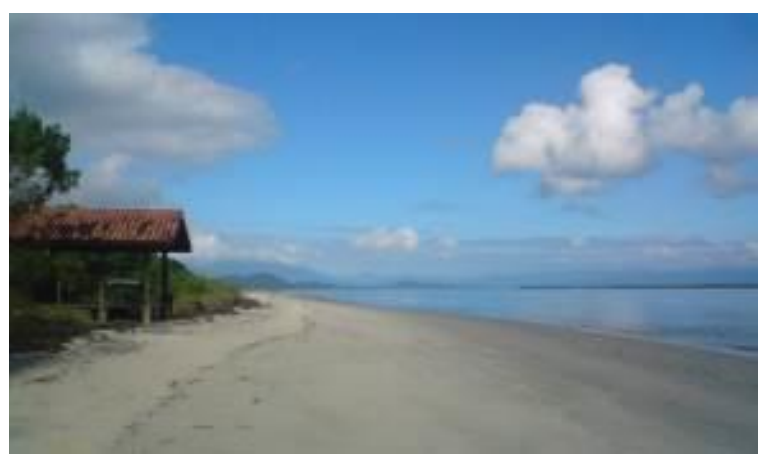

Figura 5 - Vista parcial da Praia do Itacuruçá, Comunidade do Itacuruçá Fonte: AMOIP , 2008.

Por estar perto de Cananéia, a comunidade do Itacuruçá/Pereirinha recebe um fluxo alto de visitantes, em especial durante os finais de semana e feriados. Não possui uma infraestrutura turística ampla para receber visitantes, contando apenas com duas áreas 
para camping e um restaurante. Dessa forma, a grande maioria dos visitantes apenas passa o dia, não havendo pernoite.

No final de 2014, a comunidade do Itacuruçá, por meio do conselho gestor, deu início ao processo de elaboração do Plano de Visitação ao Itacuruçá, estabelecendo regras para a visitação, em especial no que se refere ao número máximo de visitantes por dia e aos limites de atracagem das embarcações, de maneira a minimizar os impactos relativos à grande quantidade de barcos e jets ski que atracam na praia principalmente aos finais de semana. Em grandes feriados, a praia do Pereirinha chegava a receber em torno de 2.500 pessoas por dia. Observa-se que, diferentemente do Marujá, que começou esse processo de organização da atividade turística antes mesmo da elaboração do Plano de Manejo, a comunidade do Itacuruçá deu início a esse ordenamento apenas recentemente.

Boa parte dos moradores dessa comunidade reside em Cananéia, tanto por conta das opções de emprego, quanto em razão da falta de opção de educação formal para os filhos.

A comunidade da Enseada da Baleia é formada por uma pequena vila de pescadores, localizada no extremo sul da ilha (vide Figura 6). É limitada de um lado pelo Oceano Atlântico e do outro pelo Canal da Barra do Ararapira. A vila é composta por oito famílias que vivem atualmente da pesca, do turismo e de atividades relacionadas ao artesanato. Além das casas dos moradores, a comunidade possui uma capela, um centro comunitário, bar e restaurante.

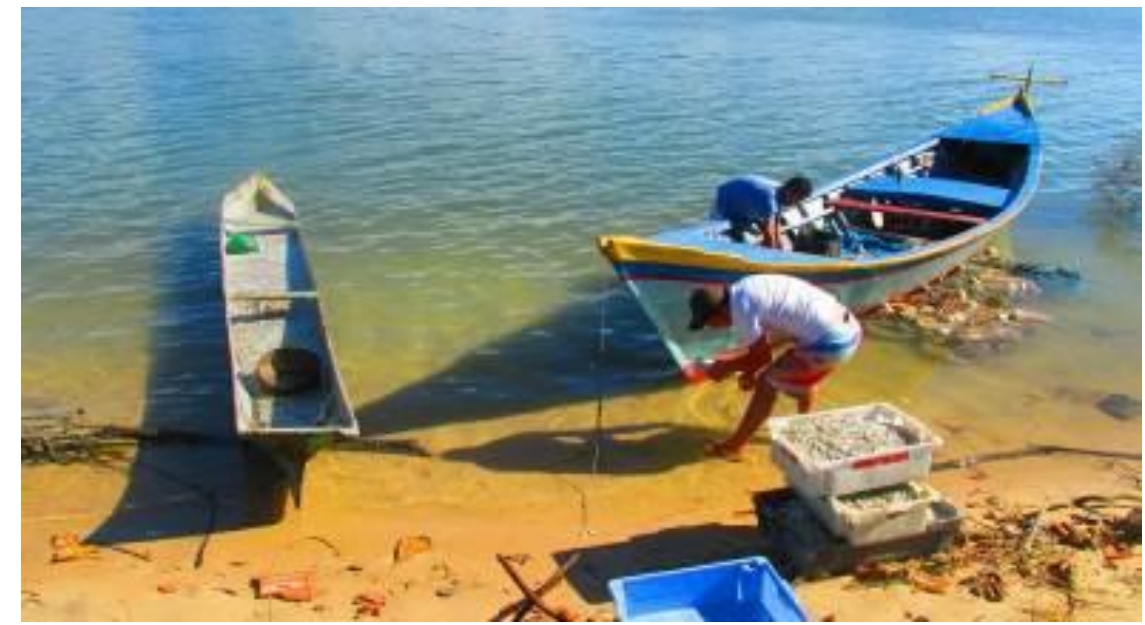

Figura 6 - Chegada da Pesca, Comunidade Enseada da Baleia

Fonte: Grupo de Mulheres Artesãs da Enseada da Baleia, 2015. 
0 turismo é uma importante atividade local, mas ainda em posição secundária em relação à pesca. As regras de visitação na comunidade, como os limites de barraca, foram definidas junto à gestão do parque. Até a morte de seu principal líder, o Sr. Malaquias, que faleceu em meados da década de 2000, a comunidade se dedicava à pesca e ao turismo. Com sua morte, os moradores começaram a se empenhar em outras atividades como forma de complementar a renda. A comunidade formou o Grupo de Mulheres Artesãs da Enseada da Baleia, composto por oito mulheres da comunidade que se dedicam a produzir artesanato dentro das comunidades, para vender aos turistas em Cananéia, de maneira a complementar a renda das famílias locais.

A comunidade vive atualmente um grande dilema com relação ao seu território, que vem agravar ainda mais os conflitos com a gestão do parque. A partir de trabalhos científicos, identificou-se recentemente um processo de erosão marinha na região onde a vila está localizada, com solapamento das margens do canal, transformando o local numa área de risco - a ilha pode ser separada em duas porções nesse ponto, pelo trabalho das correntezas do canal. Com isso, a Procuradoria Geral do Estado (PGE) emitiu um parecer que recomenda a saída dos moradores dessa comunidade. 0 assunto tem sido tema de amplos debates entre as comunidades e a gestão do parque. 


\section{ABORDAGEM TEÓRICO CONCEITUAL}

Este capítulo apresenta os referenciais teóricos e conceituais que embasam a discussão proposta pela pesquisa. A partir dos objetivos enumerados na introdução deste trabalho, considerou-se fundamental o estudo dos preceitos e teorias que envolvem comunidades tradicionais e unidades de conservação, principalmente no que se refere à participação e à gestão dos recursos naturais. A primeira parte abrange uma contextualização sobre o tema, apresentando as questões que marcam os conflitos entre comunidades tradicionais e unidades de conservação. Pretende-se esboçar, em linhas gerais, como surge o conflito e como ele afeta, por um lado, a sobrevivência das comunidades tradicionais e sua territorialidade e, por outro lado, a gestão das unidades de conservação. Na segunda parte, o foco da discussão incide sobre a participação no contexto das unidades de conservação do estado de São Paulo, bem como sobre o funcionamento dos conselhos gestores, uma das principais ferramentas de inserção das comunidades na gestão dos parques nos dias atuais. Por fim, na última parte debruça-se sobre a gestão dos recursos naturais a partir do modelo de análise, proposto por Ostrom (1990), de gestão dos commoms e de análise institucional.

\subsection{Contextualizando o conflito: unidades de conservação, território e comunidades tradicionais}

\subsubsection{O surgimento do conflito: o movimento ambiental e a criação das unidades de conservação}

A União Internacional para a Conservação da Natureza - IUCN, uma das associações internacionais mais atuantes no âmbito das áreas protegidas, define área protegida como uma área com limites geográficos definidos e reconhecidos, buscando atingir a conservação da natureza, de seus serviços ecossistêmicos e valores culturais associados por meios legais ou outros meios efetivos (DUDLEY, 2008). A Convenção sobre a 
Diversidade Biológica - CDB, assinada durante a Rio-92, define área protegida como “área definida geograficamente que é destinada, ou regulamentada, e administrada para alcançar objetivos específicos de conservação" (BRASIL, 2000, p. 9).

No Brasil, de acordo com as definições do Plano Estratégico Nacional de Áreas Protegidas - PNAP4, correspondem às áreas naturais e seminaturais regulamentadas, administradas e/ou manejadas com objetivos de conservação e uso sustentável da biodiversidade (BRASIL, 2006). Dessa maneira, as áreas protegidas abrangem as terras indígenas e terras ocupadas por remanescentes de comunidades quilombolas. Ainda de acordo com as leis ambientais brasileiras, o Sistema Nacional de Unidades de Conservação (SNUC5 $)$ define unidade de conservação como:

Unidade de conservação: espaço territorial e seus recursos ambientais, incluindo as águas jurisdicionais, com características naturais relevantes, legalmente instituído pelo Poder Público, com objetivos de conservação e limites definidos, sob regime especial de administração, ao qual se aplicam garantias adequadas de proteção (BRASIL, 2000).

0 marco histórico do surgimento das áreas protegidas no mundo ocidental foi a criação do Parque Nacional de Yellowstone, nos Estados Unidos, em 1872. De acordo com esse modelo de proteção da natureza, as áreas protegidas deveriam resguardar belas paisagens em áreas naturais sem a presença do ser humano, a não ser para visitação e contemplação.

Essa perspectiva preservacionista, influenciada em grande parte pelas ideias de John Muir, no final do século XIX, serviu de modelo para a criação de áreas protegidas no mundo todo. Os preservacionistas viam a intervenção humana de forma negativa e afirmavam que a única maneira de salvar espaços naturais de grande beleza era protegêlos da ação humana. A criação dos parques seguiu dessa dicotomia "parques e povos", excluindo populações humanas que, em muitos casos, conviviam harmoniosamente com o ambiente, causando inúmeros conflitos pela posse de terra (McCORMICK, 1992).

Ao longo do século XX, no entanto, essa perspectiva preservacionista acabou cedendo espaço à perspectiva conservacionista, que defende, ao contrário do que afirmam os

\footnotetext{
4 Plano Estratégico Nacional de Áreas Protegidas - PNAP, definido pelo decreto no 5,758, de 13 de abril de 2006.
}

${ }^{5}$ Sistema Nacional de Unidades de Conservação - SNUC, definida pela lei no9.985 de 2000. 
preservacionistas, o uso sustentável dos recursos naturais. Influenciados em grande parte pelas ideias de Gifford Pinchot, os conservacionistas foram conquistando cada vez mais espaço no movimento ambiental mundial. Essa polarização, que teve início no final do século XIX, é ainda recorrente na contemporaneidade, diferenciando aqueles que acreditam nos processos de inclusão dos residentes, em especial os tradicionais, nas unidades de conservação e aqueles que consideram a presença humana incompatível com a conservação (SIMÕES, 2010).

O surgimento do primeiro parque nacional no Brasil, o Parque Nacional de Itatiaia, no Estado do Rio de Janeiro, em 1937, representa um marco institucional no país em relação aos instrumentos legais relacionados a áreas protegidas. A partir da criação desse parque, gradativamente vão surgindo outras áreas protegidas por todo o país.

A criação das unidades de conservação, no Brasil como um todo, seguiu o modelo norte americano, que as entende como locais de conservação de uma natureza idealizada (intocada ou selvagem) e nas quais a sociedade é excluída, excetuando-se as atividades de visitação (DIEGUES, 1997). Inúmeros territórios de comunidades tradicionais foram sobrepostos por unidades de conservação, causando conflitos e impasses envolvendo a posse de terra. Segundo Diegues e Arruda (2001), os territórios dessas comunidades tradicionais, "marcados por grandes vazios", ainda que tivessem diversos usos por essas comunidades, foram sendo objeto de decretos que os transformaram em UCs, seguindo a lógica de que se tratava de espaços naturais que deveriam ser preservados.

Se analisarmos a criação das UCs no Brasil a partir da ótica das políticas públicas, é possível aferir que o modelo adotado está relacionado ao modelo top down de implementação, ou de cima para baixo, que apresenta a política pública como uma sequência de etapas distintas ou, por vezes, dicotômicas. Segundo Hill (2006), esse modelo de implementação implica em separar a formulação das políticas públicas de sua implementação, resultando na execução de ações motivadas prioritariamente por decisões políticas. As UCs foram sendo criadas, nesse contexto, pelos "tomadores de decisão de níveis mais altos" (WINTER, 2010), desconsiderando as realidades locais, tanto no que se refere à ocupação humana quanto aos diversos usos do território.

Dentre as críticas a esse modelo de implementação está a desconsideração do papel dos atores da linha de frente e que são diretamente atingidos pelas ações implementadas. No 
caso das UCs paulistas, e mesmo brasileiras, sua criação refletiu em inúmeros conflitos com comunidades, tradicionais ou não, que viviam (e vivem) nos limites delineados para a criação dessas unidades, mas que na maioria dos casos apresentavam usos e formas de interação com o meio que consideravam os ciclos naturais, gerando, por vezes, a manutenção da paisagem e dos processos ecológicos fundamentais, nas áreas onde se inseriam (BALÉE, 1993; CANELADA; JOVCHELEVICH, 1992; GOMES-POMPA; KAUS, 1992). Sob a justificativa de se preservar a natureza e de garantia de uma paisagem intocada, determinou-se o isolamento de grandes áreas naturais, deixando as comunidades que viviam nessas áreas tolhidas de seus modos tradicionais de uso e ocupação de seus territórios.

Para Ferreira et al (2002), a criação das UCs é fruto de um processo arbitrário de tomada de decisões, onde os atores partiram da "suposição de que a conservação de remanescentes florestais não seria um direito reivindicado pelas coletividades que vivem e moram nos limites territoriais de suas esferas de atuação" (FERREIRA et al, 2002, p.2). Simões (2010) complementa ao afirmar que essa atuação do Estado levou não apenas à completa desconsideração da presença de populações nos territórios demarcados por unidades de conservação de proteção integral, mas, sobretudo, à inexistência de políticas públicas focadas em gerir os diferentes tipos de usos dos recursos naturais.

Ainda que a primeira unidade de conservação no Brasil tenha sido criada na década de 1930, o movimento ambiental no Brasil só ganhou força algumas décadas depois. Jacobi argumenta que o movimento ambiental passa a ter maior representatividade no país apenas na década de 1970. 0 autor relaciona diversos fatores que explicam esse processo, a exemplo da Conferência de Estocolmo de 1972, o aumento da devastação na Amazônia e a formação de uma nova classe média brasileira, muito influenciada pelos novos ideais de qualidade de vida (JACOBI, 2003). A criação de áreas protegidas naquele período, segundo Medeiros (2004), está diretamente relacionada às ações de controle do Estado (período da ditadura) sobre o território nacional, a fim de desenvolver e integrar todas as regiões do país.

A partir da década de 1980, a questão ambiental passa a ser incorporada pelos diversos setores da sociedade, e as organizações ambientais ganham força, especialmente após a 
abertura política. A nova Constituição Brasileira, em 1988, incorpora um capítulo especial dedicado ao meio ambiente. De acordo com o artigo 225 :

Todos têm direito ao meio ambiente ecologicamente equilibrado, bem de uso comum do povo e essencial à sadia qualidade de vida, impondose ao poder público e à coletividade o dever de defendê-lo e preservá-lo para as presentes e futuras gerações (BRASIL, 1988).

Ainda de acordo com o mesmo artigo, cabe ao Poder Público definir, os espaços territoriais que deverão ser especialmente protegidos, sendo que a alteração ou supressão são autorizadas apenas por meio de lei.

A realização da Conferência das Nações Unidas para o Meio Ambiente e Desenvolvimento, que ficou conhecida como Rio 92, no Rio de Janeiro, marca outro importante acontecimento nas questões relacionadas ao meio ambiente, em escala mundial. Durante a conferência, os países participantes se comprometeram com a proteção da biodiversidade e o desenvolvimento sustentável, sendo o ponto de partida para os estudos que culminaram com o principal documento de proteção das áreas protegidas no Brasil, o Sistema Nacional de Unidades de Conservação.

A Lei 9.985 de 2000 institui o Sistema Nacional de Unidades de Conservação (SNUC), com os critérios e normas para a criação, implementação e gestão de UCs. Apresenta como grande marco uma proposta integrada de participação da sociedade civil na criação e implementação de políticas públicas ambientais. De acordo com o SNUC, tornam-se obrigatórias a elaboração de um Plano de Manejo da UC e a formação de um Conselho Gestor.

O SNUC divide as Unidades de Conservação localizadas em território nacional em Unidades de Conservação de Proteção Integral e Unidades de Conservação de Uso Sustentável. Enquanto as UCs de Proteção Integral objetivam a preservação da natureza, sendo permitida apenas a utilização indireta ${ }^{6}$ dos recursos, as UCs de Uso Sustentável objetivam compatibilizar a conservação da natureza com o uso sustentável dos recursos naturais. A responsabilidade pela criação, manutenção e gestão das UCs é do Governo Federal, juntamente com estados e municípios. A sociedade civil pode também exercer

\footnotetext{
${ }^{6}$ De acordo com o disposto na lei no 9.985/200, que institui o Sistema Nacional de Unidades de Conservação da Natureza, entende-se por uso indireto dos recursos naturais aquele que não envolve consumo, coleta, dano ou destruição dos recursos naturais (BRASIL, 2000).
} 
essa função, por meio das Reservas Particulares do Patrimônio Natural (RPPNs), categoria específica de unidade de conservação criada por proprietários de terra privados.

Segundo Irving, a divisão estabelecida pelo SNUC reflete as distintas percepções da sociedade em relação às definições de natureza, contrapondo de um lado as ideias preservacionistas, de natureza intocada, e de outro as ideias de inclusão social nas áreas protegidas, vinda dos socioambientalistas (IRVING, 2000).

No entanto, apesar dos inúmeros avanços, observa-se que a lógica preservacionista foi preponderante em parte do que discorre o SNUC. O termo "comunidades tradicionais" foi vetado do projeto de lei que deu origem ao SNUC, aparecendo apenas por meio do termo "populações tradicionais" no artigo $42^{\circ}$.

Art. 42. As populações tradicionais residentes em unidades de conservação nas quais sua permanência não seja permitida serão indenizadas ou compensadas pelas benfeitorias existentes e devidamente realocadas pelo Poder Público, em local e condições acordados entre as partes.

§ 1 o 0 Poder Público, por meio do órgão competente, priorizará o reassentamento das populações tradicionais a serem realocadas.

$\S 20$ Até que seja possível efetuar o reassentamento de que trata este artigo, serão estabelecidas normas e ações específicas destinadas a compatibilizar a presença das populações tradicionais residentes com os objetivos da unidade, sem prejuízo dos modos de vida, das fontes de subsistência e dos locais de moradia destas populações, assegurando-se a sua participação na elaboração das referidas normas e ações (BRASIL, 2000, grifos da autora).

O Parque Estadual da Ilha do Cardoso foi criado em 1962 como uma unidade de conservação de proteção integral, sendo excluída, portanto, a permanência de populações humanas em seu interior. A rigor, desde sua criação não é permitido que haja nenhum morador, seja tradicional ou não, o que causou inúmeros conflitos envolvendo moradores tradicionais, órgãos gestores e turistas de segunda residência em décadas de existência do parque. No entanto, como será aprofundado em outros capítulos, a existência de moradores é uma realidade ainda nos dias de hoje, fazendo com que esta unidade de conservação, que a princípio foi criada para ser de proteção integral, tenha uma lógica semelhante às unidades de uso sustentável, onde a permanência do morador é compatibilizada com a conservação das áreas naturais e com 
o uso sustentável dos recursos. Tal fato acabou sendo considerado na elaboração do plano de manejo, que estabeleceu as zonas e programas considerando a permanência dos moradores tradicionais.

\subsubsection{Explicitando o conflito - a justiça ambiental e a importância de aliar o natural com o social}

O movimento ambiental no mundo surge como resposta ao crescimento econômico e ao modo de produção capitalista. De acordo com Alier (2012), não há uma convergência de ideias e opiniões a respeito do ambientalismo ou ecologismo. 0 autor divide o movimento em três correntes políticas: o culto ao silvestre e ao mundo selvagem, composto pelos preservacionistas, que se opõem à presença humana em áreas naturais; a linha da ecoeficiência, adeptos do desenvolvimento sustentável, que propõem a capitalização da consciência ambiental e do uso sustentável dos recursos; e por fim o ecologismo dos pobres ou justiça ambiental, voltada para os conflitos por direitos territoriais, com significações culturais. Os adeptos dessa corrente política observam que os impactos ambientais consequência do crescimento econômico são desiguais em áreas habitadas por ricos e pobres, brancos ou minorias étnicas, atingindo grupos sociais que muitas vezes resistem e protestam em defesa de seus direitos. De acordo com essa concepção, não é possível separar o meio ambiente da sociedade:

Os objetos que constituem o "ambiente" não são redutíveis a meras quantidades de matéria e energia, pois eles são culturais e históricos: os rios para as comunidades indígenas não apresentam o mesmo sentido que para as empresas geradoras de hidroeletricidade; a diversidade biológica cultivada pelos pequenos produtores não traduz a mesma lógica que a biodiversidade valorizada pelos capitais biotecnológicos etc. Por outro lado, todos os objetos do ambiente, todas as práticas sociais desenvolvidas nos territórios e todos os usos e sentidos atribuídos ao meio, interagem e conectam-se materialmente e socialmente seja através das águas, do solo ou dá atmosfera (ACSERALD, 2004, p. 8).

O conflito envolve, portanto, as condições e formas de reprodução sociais de indivíduos e grupos sociais e suas diferentes relações de poder. Para Zhouri et. al (2005), o conflito eclode da diferença de usos e significados, "quando o sentido e a utilização de um espaço 
ambiental por um determinado grupo ocorrem em detrimento dos significados e usos que outros segmentos sociais possam fazer de seu território, para com isso assegurar a reprodução de seu modo de vida" (ZHOURI et al, 2005, p. 18). Acserald (2004) complementa, ressaltando que, em geral, o conflito envolve grupos e atores com diferentes modos de apropriação e uso do território, de modo que um se sente ameaçado em suas formas sociais de apropriação e distribuição dos recursos por impactos indesejados ou ocasionados por outros grupos.

Nesse sentido, as categorias território e territorialidade assumem importância fundamental na tentativa de compreensão do conflito. As abordagens sobre território consideram as relações de poder a partir de aspectos sociais, culturais e físicos. Godelier (apud HAESBAERT, 2009, p. 56) afirma que o território, numa abordagem simbólica, pode ser definido como uma porção da natureza, sobre a qual "uma determinada sociedade reivindica e garante a todos, ou parte de seus membros, direitos estáveis de acesso, de controle e de uso com respeito à totalidade ou parte dos recursos que aí se encontram que ela deseja e é capaz de explorar".

Sobre isso, Bonnemason e Cambrèzy (apud HAESBART, 2009) argumentam que território diz respeito não apenas ao ter, mas, sobretudo, ao ser. Território seria então definido, de acordo com essa concepção, como um construtor de identidades. Perder o território, dessa maneira, significaria também desaparecer. Essa noção de território se reflete, por exemplo, nos caiçaras do PEIC. Para eles, a permanência no parque não se trata apenas de garantir o local onde moram, mas sobretudo garantir o local que representa tudo o que eles são e construíram ao longo do tempo.

As relações de poder e hegemonia também são fundamentais para a compreensão do conflito quando se analisam os diferentes interesses que envolvem a territorialidade. De acordo com Santos (apud HAESBART, 2009), o território tem duas concepções: para os atores hegemônicos, território é recurso, de maneira que, por meio dele, garantem o atendimento e a realização de interesses particulares; para os atores hegemonizados, trata-se de um abrigo, com a busca constante pela adaptação no meio geográfico ao mesmo tempo em que recriam estratégias para garantir sua sobrevivência.

Raffestin também define território como uma produção feita a partir do espaço, com base nas relações de poder. De acordo com o autor, "qualquer projeto no espaço que é 
expresso por uma representação revela a imagem desenhada de um território, de um local de relações" (RAFFESTIN, 1993, p. 2). Para Raffestin, a territorialidade não objetiva apenas criar e manter a ordem, mas, sobretudo, trata-se de uma estratégia para criar e manter grande parte do contexto geográfico do qual experimentamos o mundo e o dotamos de significados.

As diferentes relações do homem com a natureza são destacadas por Godelier (1984, apud HAESBAERT, 2009) como definidoras das formas de propriedade de um território. Segundo o autor, território está relacionado não apenas às relações que o homem estabelece com a natureza, mas, sobretudo, às relações entre as sociedades e no interior das sociedades, entre os indivíduos e os grupos que as compõem.

Nesse contexto, é preciso que se considerem também as diferentes esferas de poder envolvidas em um mesmo território. De acordo com Haesbaert (2009), deve-se considerar a multiplicidade de poderes, que envolve inúmeros sujeitos e atores, sejam eles indivíduos, instituições, grupos sociais, poder público ou mesmo empresas privadas. Pode ser entendida como uma estratégia para influenciar ou mesmo controlar recursos e pessoas. Dessa forma, ao se analisar território, é preciso distinguir quem de fato detém o poder e, portanto, controla os espaços e, por consequência, os processos sociais que os compõem. O autor complementa: “o uso da territorialidade depende de quem está influenciando e controlando quem e dos contextos geográficos de espaço, lugar e tempo" (HAESBAERT, 2002, p. 86).

No caso das UCs, essa multiplicidade de poderes se reflete na diversidade de interesses, nos diferentes olhares do poder público, dos gestores das UCs, das comunidades tradicionais, dos proprietários de terra privados e dos ambientalistas. Sobre isso, vale destacar que os ambientalistas, em geral, consideram os territórios de animais topos de cadeia e utilizam esse parâmetro para delinear limites de unidades de conservação, sem considerar, muitas vezes, o território simbólico das comunidades tradicionais, por exemplo, agravando conflitos pela posse de terras. Vê-se claramente a formação de inúmeros conflitos desse tipo quando analisamos a criação de UCs, em especial e como ocorre na grande maioria dos casos, em territórios habitados por populações humanas. Medeiros (2006) avalia que, de forma agravante, a criação e implementação de áreas protegidas ocorre, em geral, "de forma autoritária e pouco negociada com os diferentes 
segmentos locais pelo Estado", causando desordens e conflitos em decorrência da ausência de estratégias claras de integração das unidades à dinâmica local.

Esses conflitos, em sua grande maioria, se estabelecem em função da dissonância de Políticas Públicas, que resulta, frequentemente, no direcionamento de uso do mesmo espaço geográfico e apropriação da terra para diferentes formas de utilização (cultivo, extrativismo, roça, exploração da madeira, implantação de assentamentos e áreas indígenas, construção de estradas, exploração mineral etc.), formas estas que, frequentemente, contrariam o estatuto de proteção da área em questão (MEDEIROS, et al, 2006, p. 35).

Para Diegues, essa prática de impedir o uso de recursos naturais em algumas categorias de unidade de conservação é discriminatória, na medida em que não leva em consideração a importância de algumas populações tradicionais na conservação da natureza. De acordo com o autor (1997, p. 100): "fala-se em interferência humana negativa sobre as áreas naturais protegidas sem se fazer distinção entre os interesses econômicos externos às áreas e às atividades daquelas populações" que efetivamente contribuíram para a conservação ambiental. Esse modelo de criação das unidades de conservação, portanto, não apenas está na base de graves conflitos pelo direito ao território, como também não é adequado às condições ecológico-sociais dos países do sul (DIEGUES, 1997, 2000).

De acordo com publicação lançada pelo Ministério Público em 2014, o movimento que acompanha a criação e implementação das unidades de conservação é o da exclusão das comunidades, na medida em que os modos de vida das comunidades tradicionais são inviabilizados em favor de atividades consideradas mais adequadas para as áreas naturais. A partir da criação dessas UCs, geram-se conflitos a partir da sobreposição de "representações simbólicas antagônicas e paradoxais sobre o significado da natureza" (MPF, 2014, p. 91). São concepções equivocadas que transformam as UCs em "ilhas de conservação", sem considerar as condições de conservação do ambiente desses espaços protegidos, tampouco o uso sustentável dos recursos no entorno das unidades e, sobretudo, o papel relevante das comunidades na conservação dessas áreas.

Em contraposição à ideia de criação de espaços protegidos, há quem afirme que a criação das unidades de conservação, por si só, não garante a conservação das áreas naturais. De acordo com Simões (2010), estudos realizados por Campos (2006), confirmaram que a implantação das unidades de conservação, em alguns casos, acabou 
por contribuir para o aumento do dano ambiental. A autora ressalta que atividades antes consideradas tradicionais, praticadas com regras mínimas por populações locais, se transformaram em ilegais pela legislação, levando à intensificação de práticas "impactantes e irregulares, ao serem mantidas clandestinamente" (SIMÕES, 2010. p.5).

Cada vez mais proliferam os estudos que associam a preservação de áreas naturais à manutenção das comunidades tradicionais. Guimire (apud ADAMS, 2000) argumenta que a expansão das áreas protegidas foi acompanhada, de um lado, pela remoção de populações tradicionais e o dilaceramento de seus modos de vida e, de outro, pelo aumento das taxas de desmatamento dessas áreas. De certo modo, defende-se que a relação de baixo impacto no uso dos recursos dessas comunidades tradicionais com o meio ambiente foi a grande responsável justamente pela manutenção dessas áreas naturais, e sua expulsão tem acarretado a degradação de áreas antes preservadas pelas comunidades, conforme afirma Adams:

(...) com o passar dos anos, a experiência tem mostrado que a expulsão dos moradores tradicionais das áreas de preservação e a proibição dos usos que estes faziam dos recursos naturais não só não foi suficiente para conter a degradação dessas áreas, como em muitos casos acentuou o processo (ADAMS, 2000, p. 21).

Assim, na década de 1980 surgem as discussões nas ciências humanas relacionadas ao manejo de UCs, que afloram esse problema. Estudos demonstram o surgimento de novas possibilidades de "sobrevivência" dessas populações, por meio do reconhecimento, ainda que incipiente, das comunidades como importantes ferramentas de valorização e preservação ambiental. Conforme afirma Leff:

A cultura está sendo revalorizada como um recurso para o desenvolvimento sustentável. (...) A organização cultural das etnias e das sociedades camponesas tradicionais estabelece um sistema de relações sociais e ecológicas de produção que dá suporte às práticas de manejo integrado e sustentável dos recursos naturais (LEFF, 2001, p. 329).

Por outro lado, é preciso considerar também que as populações são vulneráveis perante as políticas do Estado, mas, sobretudo, perante as políticas do mercado e do capital. Em muitos casos, observa-se que a criação das unidades de conservação contribuiu diretamente para minimizar impactos diretos sobre as comunidades, no que se refere, por exemplo, às pressões de grandes empresas e à especulação imobiliária. Raimundo argumenta que a criação do Parque Estadual da Serra do Mar, por exemplo, conseguiu 
frear os processos de ocupação, restringindo-os ao interior das vilas caiçaras que já existiam antes da criação do parque (RAIMUNDO, 2007). Sobre isso, Simões (2010) argumenta que, em diversas situações em que foram criadas unidades de conservação de proteção integral em territórios ocupados por comunidades, a exemplo da comunidade de Picinguaba, no litoral norte paulista, objeto de estudo da tese de doutorado da autora, observou-se que, se as UCs não tivessem sido criadas, é bem provável que a situação das populações estivesse muito pior, "sobretudo devido às pressões de setores econômicos disputando os mesmos territórios" (SIMÕES, 2010, p. $3)$.

No PEIC, se por um lado a criação do parque causou inúmeros conflitos com os moradores locais, também foi responsável, como afirmam os próprios moradores, por barrar o processo de especulação imobiliária, garantindo, ainda que não legalmente, alguns direitos de permanência dos tradicionais e a posterior expulsão dos turistas proprietários de imóveis de segunda residência da ilha.

No âmbito da justiça ambiental, Acserald (2010) propõe a junção entre justiça social e proteção ambiental, de maneira que os custos ambientais do crescimento não sejam mais transferidos para os mais pobres: "para barrar a pressão destrutiva sobre o ambiente de todos, é preciso começar protegendo os mais fracos" (ACSERALD, 2010, p. 114). Entender o conflito é parte essencial do enfrentamento da crise socioambiental. Partindo-se do pressuposto de que não há desenvolvimento sem justiça ambiental, fazse necessário compreender a real necessidade de criação de espaços naturais protegidos, qual seja o de proteger o ambiente natural, considerando necessariamente as causas de grupos vulneráveis, por meio da manutenção e do apoio aos grupos sociais que vivem nessas áreas.

Medeiros (2006) reforça que, embora esses conflitos estejam gerando efeitos perversos à consolidação do SNUC, têm contribuído também para uma "agenda positiva" de proteção da natureza, corroborando para a inserção do processo de participação na gestão das UCs, à criação de novas categorias de UCs, mais adequadas às demandas sociais, e novos modelos de parcerias na gestão.

Os mecanismos de participação têm sido considerados como ferramenta de gestão em muitos momentos da história do PEIC. Não à toa, o parque foi o primeiro no estado de 
São Paulo a contar com um Plano de Manejo elaborado de maneira participativa e um conselho gestor, antes mesmo de sua obrigatoriedade ser instituída pelo SNUC. Ainda que o conflito não tenha sido resolvido, já que, por um lado, a gestão do parque tem que lidar com moradores residindo nos limites de uma UC de proteção integral e, por outro lado, os moradores não conquistaram o direito legal de permanência, observam-se tentativas de minimização do conflito de ambos os lados. A resolução do conflito que permeia as comunidades tradicionais e as unidades de conservação perpassa, necessariamente, por seu enfretamento e pela utilização de recursos, mecanismos e ferramentas que garantam o consenso entre os diferentes atores.

\subsubsection{O conflito para as comunidades caiçaras}

De acordo com a Política Nacional de Desenvolvimento Sustentável dos Povos e Comunidades Tradicionais (Brasil, 2007), as comunidades tradicionais são definidas como:

(...) grupos culturalmente diferenciados e que se reconhecem como tais, que possuem formas próprias de organização social, que ocupam e usam territórios e recursos naturais como condição para sua reprodução cultural, social, religiosa, ancestral e econômica, utilizando conhecimentos, inovações e práticas gerados e transmitidos pela tradição (BRASIL, 2007).

Para Adams (2000), a utilização do termo populações tradicionais, ainda que tenha se tornado senso comum, acaba por designar as populações de maneira extremamente genérica. A autora salienta que, internacionalmente, o termo é utilizado como adjetivo para caracterizar determinados tipos de sociedades e sua relação com o território e com a utilização de recursos, modos de vida e culturas, enquanto no Brasil o termo ainda é associado, geralmente, a sociedades rústicas.

Diegues e Arruda (2001) argumentam que as populações tradicionais são caracterizadas, em grande parte, por modos de produção pré-capitalista, marcadas por sua relação com formas de manejo dos recursos naturais que não estão voltadas para a obtenção de lucro, mas, sobretudo, para a reprodução social e cultural desses povos. Ainda que hoje em dia seja possível observar que boa parte das comunidades já está 
mais inserida nas relações capitalistas de produção, há ainda formas não capitalistas praticadas pelas comunidades tradicionais.

O modo de vida das comunidades tradicionais é justamente o que as distingue de outros grupos da sociedade, sendo marcado essencialmente por sua relação com o meio natural. Diegues e Arruda (op. cit.) destacam a importância de analisar o sistema de representações, símbolos e mitos que essas populações constroem, pois é com ele que agem sobre o meio natural. Por meio dessas representações mentais e do conhecimento empírico acumulado, é que desenvolvem seus sistemas tradicionais de manejo.

Devido à abrangência do termo "comunidades tradicionais", diversos autores estabelecem algumas distinções, com base em aspectos culturais referindo-se, a priori, às comunidades indígenas e não indígenas, sendo as últimas classificadas em caiçaras, caipiras, ribeirinhos, quilombolas, sertanejos, entre outros. Os critérios utilizados para tal divisão estão baseados no contexto cultural e no modo de vida que podem ser observados em cada uma dessas comunidades e que, portanto, as distinguem entre si.

Por conta do objeto do presente estudo, faz-se necessário tecer uma breve explanação a respeito das definições que envolvem os povos ditos caiçaras. Diegues e Arruda (2001) definem os caiçaras como:

(...) aquelas comunidades formadas pela mescla da contribuição étnicocultural dos indígenas, dos colonizadores portugueses e, em menor grau, dos escravos africanos. Os caiçaras apresentam uma forma de vida baseada em atividades de agricultura itinerante, da pequena pesca, do extrativismo vegetal e do artesanato. Essa cultura se desenvolveu principalmente nas áreas costeiras dos atuais estados do Rio de Janeiro, São Paulo, Paraná e norte de Santa Catarina (DIEGUES e ARRUDA, 2001, p. 42).

De acordo com Adams (2000), o termo caiçara tem origem na palavra tupi-guarani caáiçara, que significa o homem do litoral. 0 termo era originalmente utilizado para denominar as estacas colocadas na água para cercar o peixe. No entanto, com o passar do tempo acabou virando sinônimo das palhoças construídas nas praias para abrigar canoas e apetrechos de pescadores, até que passou a designar os próprios moradores de Cananéia e, então, todos os moradores e comunidades do litoral dos estados do Paraná, São Paulo e Rio de Janeiro (FUNDAÇÃo soS MATA ATLÂNTICA, 1992; DIEGUES, 1988). 
A terra ou o meio em que habitam, de acordo com Raimundo (2007), é fundamental para entender o caiçara enquanto categoria camponesa, em especial no que se refere à sua forma de apropriação do meio e ao seu modo de vida.

Com isso, a terra, além de ser um encadeamento de ações técnicas, é também para o Caiçara um encadeamento de ações simbólicas. Antes de agirem sobre o meio modificando-o, os agricultores familiares procuram fazer uma releitura desse ambiente, observando suas potencialidades e limitações na expectativa de criar um tipo de agricultura possível naquele local (RAIMUNDO, 2007, p. 95).

De maneira geral, os caiçaras possuem algumas características que podem ser identificadas, em maior ou menor grau, em boa parte das comunidades consideradas caiçaras: pequena agricultura de subsistência e a pesca como principais atividades econômicas; a praia como centro da vida comunitária; propriedades não cercadas envoltas de trilhas que levam à praia; papel da mulher na manutenção do grupo familiar, enquanto dona de casa, trabalhadora do lar e da roça (ADAMS, 2000). A solidariedade entre os membros da comunidade é apontada pela autora como importante fator de equilíbrio e de organização para os caiçaras, a exemplo dos trabalhos coletivos e dos mutirões, comuns nesse tipo de sociedade, e que explica, em partes, sua organização e integração.

Historicamente, as comunidades caiçaras sempre mantiveram contatos sociais e econômicos com as cidades e, desde a década de 1960, vêm enfrentando problemas, tanto no que se refere à criação de Unidades de Conservação em áreas litorâneas, quanto à especulação imobiliária e ao turismo de massa, que podem causar graves impactos nos modos de vida tradicionais dessas comunidades e em seus territórios tradicionais e simbólicos.

A Política Nacional de Desenvolvimento Sustentável dos Povos e Comunidades Tradicionais (2007) define os Territórios Tradicionais como "os espaços necessários à reprodução cultural, social e econômica dos povos e comunidades tradicionais, sejam eles utilizados de forma permanente ou temporária". Compreender as relações estabelecidas entre as comunidades e seus respectivos territórios é de suma importância para entender os conflitos que permeiam as políticas públicas, as unidades de conservação, as comunidades tradicionais e a participação na gestão de tais áreas. 
De acordo com Diegues e Arruda (2001), para os caiçaras, o território é descontínuo e marcado por vazios aparentes, levando o poder público ou as "autoridades da conservação" a declarar tais territórios como espaços a serem conservados, partindo-se do pressuposto de que não são utilizados por ninguém: "aí reside, muitas vezes, parte dos conflitos existentes entre essas sociedades e as autoridades conservacionistas" (DIEGUES e ARRUDA, 2001, p. 20).

Diferentemente das populações tradicionais que já conquistaram uma regulamentação própria, que lhes assegure o direito ao território, a exemplo dos indígenas e dos quilombolas, os caiçaras ainda hoje lutam para conquistar seus direitos de permanência em seus territórios. Não há uma política clara que garanta seus direitos, tampouco que os resguarde de outras políticas.

As reflexões teóricas abordadas nesse capítulo permitiram que se compreendesse mais a fundo a problemática de apropriação dos recursos naturais que envolvem as raízes dos conflitos presentes na criação de unidades de conservação, cujas áreas são também territórios de populações tradicionais. Entender a importância do território para as comunidades tradicionais é entender porque há tanta luta e resistência por parte desses povos mesmo depois de décadas desde a primeira unidade de conservação instituída. À luz do contexto histórico do movimento ambientalista e da criação das unidades de conservação, é possível compreender os diversos interesses políticos, econômicos e sociais, bem como os jogos de poder que envolvem as disputas por território e a criação das áreas protegidas, em contraposição aos direitos das populações tradicionais, historicamente mais vulneráveis. No próximo capítulo, serão abordados conceitos relacionados à participação e sua importância na gestão de áreas protegidas.

\subsection{Participação e políticas públicas voltadas para Unidades de Conservação no Estado de São Paulo}

A discussão a respeito da participação tem se tornado cada vez mais comum, não apenas no mundo acadêmico, mas, sobretudo, no próprio contexto das políticas públicas. 0 crescente enfoque desse tema, de maneira geral, tem relação direta com o avanço da 
democracia no país e também com a importância que vem sendo dada ao tema internacionalmente. Cada vez mais, há um reconhecimento da importância da participação em todas as fases que envolvem as políticas públicas, de maneira que as ações empreendidas sejam de fato efetivas na construção do desenvolvimento social.

No Brasil, a ideia de ampliação da participação na formulação, implementação e execução de políticas públicas é bastante recente. 0 histórico de participação, inclusive, tem seu marco fundamental apenas com a Constituição de 1988, por meio da política de descentralização administrativa, em um contexto histórico marcado pelo reestabelecimento da democracia e pelas lutas empreendidas, em especial, pelos movimentos sociais.

Dagnino (2004) afirma que o Brasil vive hoje um grande dilema no que se refere aos processos democráticos. Se, por um lado, vislumbra-se um alargamento da democracia, com a crescente participação da sociedade civil nos processos de discussão e tomada de decisão de políticas públicas, por outro lado, vê-se também o crescimento da ideia de “Estado Mínimo”, com o distanciamento cada vez maior do Estado enquanto garantidor de direitos, transferindo gradativamente suas responsabilidades sociais para a sociedade civil.

A autora chama a atenção para esse "dilema perverso", argumentando que, apesar de se tratar de ideias e projetos antagônicos, ambos demandam sociedades que sejam ativas e propositivas. Dessa perversidade, tem-se que, se por um lado a sociedade civil tem espaço para realmente fazer parte das políticas públicas, por outro lado essa mesma participação que, segundo a autora, deveria servir como mecanismo democrático de redução da exclusão, pode acabar por servir justamente a objetivos contrários a esse, se transformando em instrumento de controle e aparente participação (DAGNINO, 2004).

De qualquer maneira, é indiscutível a importância da participação, principalmente se a considerarmos como ferramenta de boa governança. De acordo com Bandeira (1999, p. 31), a participação deve ser vista como importante ferramenta de integração entre os diversos atores sociais, fortalecendo a articulação e a tomada de decisões visando ao alcance dos objetivos de interesse em comum. Dagnino complementa, afirmando que a participação tem papel decisivo no processo de formação e consolidação de identidades regionais, que facilitam a construção de consensos entre os atores sociais, 
imprescindíveis para o desenvolvimento (DAGNINO, 2004). Integração, consenso e aprendizagem coletiva são elementos fundamentais no processo de participação e desenvolvimento social.

De acordo com Abers et al (2010), os estudiosos da democracia deliberativa defendem que, além da simples participação democrática reduzida a ações individualizadas, é fundamental a multiplicação de espaços nos quais os indivíduos e grupos possam interagir e fazer escolhas coletivas. De acordo com os autores, esse processo de interação contribui para que as pessoas tenham outra percepção sobre seus próprios interesses e reconheçam os interesses dos outros. A participação, sob o viés da democracia deliberativa, é situada em três pilares: inclusão política, processos deliberativos interativos e aumento do controle da sociedade sobre o Estado. Parte-se do pressuposto de que, para que haja de fato deliberação, é preciso que haja inclusão de todos, sem predomínios econômicos ou mesmo políticos.

No âmbito das unidades de conservação de proteção integral com registro de populações em suas áreas, sejam tradicionais ou não, a participação na gestão das áreas protegidas é de suma importância, tanto para a conservação ambiental, quanto para a manutenção das comunidades tradicionais e a minimização dos conflitos existentes nessas áreas. Conforme afirma o Ministério Público Federal - MPF (2014):

(...) o ponto crítico da gestão de espaços protegidos onde há presença de povos ou comunidades tradicionais remete ao seu aspecto mais relevante, qual seja a possibilidade de participação dessas comunidades, a partir da circulação de conhecimentos e da valorização de seus saberes sobre o ambiente e de suas formas de manejo de recursos (MPF, 2014, p. 91).

Ayres e Irving afirmam que a inclusão social em áreas protegidas deve ser encarada como um novo paradigma nas práticas de gestão, onde o grande desafio que se apresenta é o "fazer coletivo" (AYRES e IRVING, 2006, p. 77). Considerando as questões complexas que envolvem essa construção coletiva, a existência de espaços formais e informais de participação, juntamente com políticas públicas fortes e integradoras, são condições essenciais para que se alcance essa essência coletiva.

À medida que são deslocados da clandestinidade e reconhecidos como interlocutores e participantes legítimos da gestão, as chances de que estes grupos de posicionem como aliados dos objetivos 
conservacionistas aumentam significativamente, como tem demonstrado inúmeras experiências (MPF, 2014, p. 92).

Observa-se que, em situações de conflito, o modelo de gestão baseado na inclusão requer o envolvimento de todos os atores sociais, numa relação muito mais voltada para a corresponsabilidade e a interdependência. Sobre isso, o MPF (2014) observa que os membros das comunidades tradicionais devem se esvaziar de suas posições historicamente construídas de "opositores, dificultadores, oponentes, invasores e degradadores" (MPF, 2004, p. 91), para se tornarem interlocutores e sujeitos no contexto da preservação e do uso dos recursos de maneira sustentável, alcançando a legitimidade e a visibilidade necessárias para participar da gestão.

O tema participação não é exclusivo dos simpatizantes e defensores da causa. A participação tem sido considerada como estratégia e, inclusive, como ferramenta de ação até mesmo no âmbito das políticas públicas ambientais. O PEIC se destaca neste contexto como o primeiro parque no estado de São Paulo a contar com um Plano de Manejo elaborado com a comunidade e com um fórum de participação, que se tornaria o primeiro conselho gestor de parque do Estado.

\subsubsection{A participação nas Unidades de Conservação do Estado de São Paulo}

No estado de São Paulo, as Unidades de Conservação (UCs) estão sob responsabilidade da Fundação Florestal, órgão vinculado à Secretaria de Estado do Meio Ambiente, que, entre outras funções, atua na implementação de políticas públicas voltadas para áreas naturais protegidas do Estado.

As UCs começaram a ser criadas no Estado em maior número partir da década de 1960. Antes disso, observam-se apenas duas UCs: Parque Estadual Campos do Jordão e o Horto Florestal, atual PE Alberto Loefgren. Apesar de existirem diversos diplomas legais específicos e gerais sobre UCs, como o decreto de parques paulistas ${ }^{7}$ e as leis de crimes

\footnotetext{
${ }^{7}$ Decreto estadual no 25.341, de 4 de junho de 1986.
} 
ambientais $^{8}$, entre outros, nenhum deles considerava as comunidades tradicionais inseridas no entorno ou interior desses espaços.

Em São Paulo, o histórico de participação no âmbito das políticas públicas ambientais em unidades de conservação tem seu marco em 1996, por meio da implantação do Projeto de Preservação da Mata Atlântica (PPMA), desenvolvido pela Secretaria Estadual de Meio Ambiente, em parceria com o governo alemão (RAIMUNDO; MATHEUS, 2013; VALLE; RAIMUNDO, 2015). 0 projeto previa as melhorias ambientais na região do Vale do Ribeira e Litoral Paulista e o planejamento e consolidação de nove UCs paulistas. Entre os objetivos e estratégias de ação do projeto, a abordagem participativa constava como uma das diretrizes principais, conforme se observa a seguir:

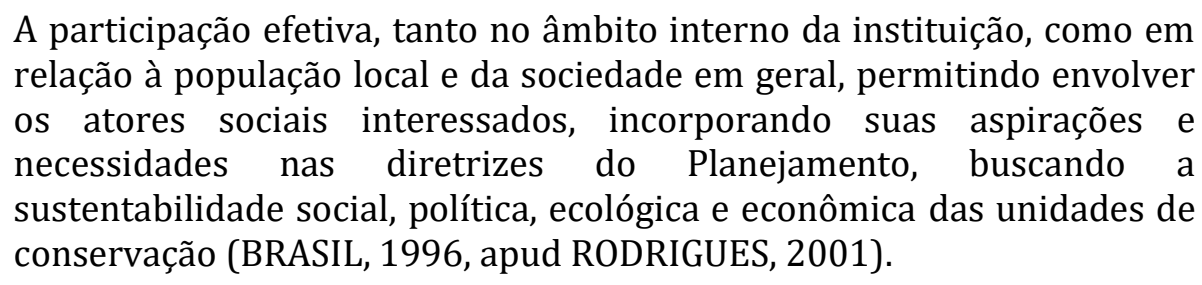

Um dos componentes do projeto abrangia a elaboração de Planos de Gestão Ambiental para nove UCs paulistas, sob a coordenação do Instituto Florestal e da Fundação Florestal. Desde o princípio, a elaboração de tais planos pretendia envolver as comunidades e demais atores no processo de definição de objetivos, metas e atividades em cada uma das UCs contempladas (MARETTI et al, 1997).

Em linhas gerais, o PPMA era focado na elaboração dos planos de gestão ambiental (um plano mais expedito, elaborado para enfrentar os principais problemas da UC, enquanto o plano de manejo é mais detalhado e elaborado a partir das lacunas e avanços do plano de gestão ambiental), cujas premissas embasavam-se na abordagem participativa coletiva dos atores envolvidos na gestão das UCs. Assim, para implantar a abordagem participativa, concomitantemente à elaboração do plano de gestão ocorria a escolha dos membros que iriam compor os Comitês de Apoio à Gestão Ambiental das UCs do projeto, embrião dos posteriores Conselhos Consultivos das UCs.

\footnotetext{
${ }^{8}$ Lei no 9.605, de 12 de fevereiro de 1998.
} 
No entanto, Rodrigues (2001) aponta uma série de obstáculos e dificuldades enfrentados na elaboração e implantação dos planos, que vão desde os métodos empregados no processo até o entendimento das relações que se estabelecem entre os moradores locais e o lugar em que vivem. Segundo a autora, as metodologias empregadas em projetos que envolvem comunidades e unidades de conservação, em sua maioria, são focadas em neutralizar conflitos existentes, e não em resolvê-los, além de ignorarem os conhecimentos locais e a participação efetiva das comunidades no processo de construção do planejamento. Ainda, por se tratar de um projeto com data de finalização, e não exatamente uma política pública, em várias das unidades os processos iniciados foram descontinuados, seja por desmobilização local, seja por interesses diversos dos atores envolvidos.

Há que se ressaltar ainda que, como aponta Rodrigues (2001), dentro da própria Secretaria de Estado do Meio Ambiente, havia conflitos de interesses entre os que defendiam a permanência das comunidades em UCs e os que eram contra, dificultando ainda mais o estabelecimento de políticas realmente participativas por parte desse órgão estadual. Nesse contexto, cabe mencionar a elaboração do Plano de Gestão Ambiental do Parque Estadual da Ilha do Cardoso, considerado modelo de projeto participativo, conforme comentado anteriormente.

No que se refere à esfera federal, o ano de 2000 marca a instituição do Sistema Nacional de Unidades de Conservação (SNUC), como arcabouço legal das normas para criação e gestão de UCs no Brasil. No tocante à temática da participação, o SNUC também se apresenta como referencial ao se apoiar em diretrizes que buscam a participação das populações locais na gestão das UCs. A Lei estabelece diversas normas que regulamentam a participação da sociedade civil na gestão das UCs e expressam a necessidade desse envolvimento no planejamento, criação e gestão das UCs, conforme segue:

Art. 5o - O SNUC será regido por diretrizes que:

III - assegurem a participação efetiva das populações locais na criação, implantação e gestão das unidades de conservação;

IV - busquem o apoio e a cooperação de organizações nãogovernamentais, de organizações privadas e pessoas físicas para o desenvolvimento de estudos, pesquisas científicas, práticas de educação 
ambiental, atividades de lazer e de turismo ecológico, monitoramento, manutenção e outras atividades de gestão das unidades de conservação;

$\mathrm{V}$ - incentivem as populações locais e as organizações privadas a estabelecerem e administrarem unidades de conservação dentro do sistema nacional;

Art. 22 - As unidades de conservação são criadas por ato do Poder Público.

§ 20 - A criação de uma unidade de conservação deve ser precedida de estudos técnicos e de consulta pública que permitam identificar a localização, a dimensão e os limites mais adequados para a unidade, conforme se dispuser em regulamento (BRASIL, 2000).

Por meio do SNUC, foram estabelecidos dois instrumentos de gestão de Unidades de Conservação: os planos de manejo e os conselhos gestores. A lei estabelece a participação da sociedade civil no âmbito das consultas públicas e da formação dos conselhos gestores. De acordo com o decreto de instituição do SNUC (BRASIL, 2000), foi estabelecida a obrigatoriedade de formação de conselhos gestores em todas as Unidades de Conservação, devendo ser deliberativo, no caso das UCs de Uso Sustentável, e consultivo, no caso das UCs de Proteção Integral (caso dos parques).

O Artigo 29ำ institui a obrigatoriedade de organização de Conselho Consultivo, no caso das UCs de Proteção Integral:

Art. 29. Cada unidade de conservação do grupo de Proteção Integral disporá de um Conselho Consultivo, presidido pelo órgão responsável por sua administração e constituído por representantes de órgãos públicos, de organizações da sociedade civil, por proprietários de terras localizadas em Refúgio de Vida Silvestre ou Monumento Natural, quando for o caso, e, na hipótese prevista no $\S 20$ do art. 42, das populações tradicionais residentes, conforme se dispuser em regulamento e no ato de criação da unidade (BRASIL, 2000, grifo da autora).

0 referido artigo amplia a participação da sociedade civil, mencionando inclusive a participação das populações tradicionais nos processos de decisão na gestão das UCs de Proteção Integral.

Com relação às comunidades tradicionais, de acordo com o disposto no Artigo $42^{\circ}$ (BRASIL, 2000), em unidades de conservação onde não é permitida a presença de moradores, como é o caso das UCs de proteção integral, deverão ser tomadas medidas que assegurem a permanência das comunidades na unidade, até que seja possível seu reassentamento. Ainda que não garanta direitos concretos de permanência no território, 
o artigo possibilita uma abertura maior em direção às possibilidades de garantia de direitos por parte das comunidades tradicionais.

Até que seja possível efetuar o reassentamento de que trata este artigo, serão estabelecidas normas e ações específicas destinadas a compatibilizar a presença das populações tradicionais residentes com os objetivos da unidade, sem prejuízo dos modos de vida, das fontes de subsistência e dos locais de moradia destas populações, assegurando-se a sua participação na elaboração das referidas normas e ações (BRASIL, 2000).

Em São Paulo, o ano de 2005 marca a instituição do Decreto Estadual 49.672, que regulamenta a criação e o funcionamento dos conselhos gestores das unidades de conservação de proteção integral. De acordo com o decreto, os conselhos deverão seguir os seguintes princípios:

Artigo 4ํㅡ - Os Conselhos Consultivos das Unidades de Proteção Integral estaduais são órgãos colegiados voltados a consolidar e legitimar 0 processo de planejamento e gestão participativa, devendo pautar suas ações com base nos seguintes princípios:

I - valorização, manutenção e conservação dos atributos naturais protegidos;

II - otimização da inserção da Unidade de Conservação no espaço regional, auxiliando o ordenamento das atividades antrópicas no entorno da área;

III - busca de alternativas de desenvolvimento econômico local e regional em bases sustentáveis no entorno da Unidade de Conservação;

IV - otimização do aporte de recursos humanos, técnicos e financeiros;

V - divulgação da importância dos serviços ambientais prestados pela área protegida, sensibilizando as comunidades local e regional para a preservação;

VI - aplicação dos recursos na busca dos objetivos da Unidade de Conservação, observadas as regras que regem a administração pública (SÃO PAULO, 2005).

Observa-se que não há menção, entre os princípios norteadores dos conselhos gestores, às comunidades ou populações tradicionais residentes nas UCs, comum em boa parte das UCs do estado de São Paulo. Embora sejam consideradas como possíveis integrantes do conselho, representando a sociedade civil, é visível a ausência ou mesmo instituição da participação das comunidades tradicionais nas diretrizes, objetivos e, inclusive, no 
que se refere às atribuições do conselho. Propõe-se a articulação com os residentes, mas não sua efetiva participação nas ações.

Artigo 5ํ - Cada Conselho Consultivo de Unidade de Conservação de Proteção Integral terá as seguintes atribuições:

I - elaborar seu regimento interno, no prazo de 90 (noventa) dias, contados a partir da data da sua instalação;

II - acompanhar a elaboração, implementação e revisão do Plano de Manejo da Unidade de Conservação, garantindo seu caráter participativo e sugerindo ações para seu aperfeiçoamento;

III - buscar a integração da Unidade de Conservação com as demais unidades e espaços territoriais especialmente protegidos e com o seu entorno;

IV - estimular a articulação dos órgãos públicos, organizações nãogovernamentais, população, residente e do entorno, e iniciativa privada, para a concretização dos planos, programas e ações de proteção, recuperação e melhoria dos recursos ambientais existentes;

V - manifestar-se, quando provocado, sobre obra ou atividade potencialmente causadora de impacto ambiental no raio fixado para seu entorno;

VI - auxiliar na captação de recursos complementares para a efetiva implementação do Plano de Manejo e otimização dos serviços ambientais e usos permitidos nas áreas integralmente protegidas;

VII - avaliar os documentos e opinar sobre as propostas encaminhadas por qualquer cidadão ou entidade pública ou privada, que manifeste interesse em utilizar a área ou colaborar com as atividades permitidas pelo Plano de Manejo da Unidade de Conservação de Proteção Integral;

VIII - opinar sobre a elaboração de normas administrativas da Unidade de Conservação, com base na legislação ambiental específica, bem como na realidade socioambiental da Unidade de Conservação e seu entorno, visando ordenar, quando couber, entre outras, o uso público, as práticas de esportes de aventura, programas de voluntariado, práticas de educação ambiental e atividades de pesquisa científica;

IX - solicitar, sempre que necessária, a presença de especialistas da Secretaria do Meio Ambiente, ou de outros órgãos públicos, para assessorar, subsidiar e acompanhar assuntos técnicos, científicos e jurídicos relevantes para a gestão da Unidade de Conservação (SÃo PAULO, 2005, grifo da autora).

Considerando o contexto das políticas públicas, alguns autores discorrem sobre os processos sobre os quais determinados assuntos apresentam significância para os governos e acabam por integrar a sua agenda de prioridades. Kingdon (2006, p.237) 
define a agenda governamental como "uma lista de temas que são alvo de atenção por parte das autoridades em um dado momento". A partir dessas agendas, alguns temas são priorizados em detrimento de outros. Um dado problema pode ou não vir a se tornar alvo de uma política pública, de acordo com o autor, por meio das janelas para políticas públicas, que se constitui de oportunidades para que tal problema venha a ser alvo da atenção do governo e seus atores.

Quando uma janela se abre, problemas e propostas são imediatamente trazidos à tona. As pessoas preocupadas com problemas específicos percebem uma janela aberta como uma oportunidade de tratar e até resolver esses problemas. Defensores de propostas percebem essa janela como uma oportunidade de colocar suas propostas em ação. (...) Janelas abertas apresentam oportunidades para que haja uma ligação completa entre problemas, propostas e políticas, e assim criam oportunidades de introduzirem-se pacotes completos com os três elementos para o topo das agendas de decisões (KINGDON, 2006, p. 237).

No ano de 2006, o Governo do Estado de São Paulo cria o Sistema Estadual de Florestas (SIEFLOR), por meio do decreto $\mathrm{n}$ o 51.453. O SIEFLOR abrange as unidades de conservação do estado de São Paulo, tendo como órgão executor a Fundação Florestal e o Instituto Florestal, e como órgão consultivo e deliberativo o Conselho Estadual de Meio Ambiente (CONSEMA), que tem como atribuições acompanhar e implementar o sistema. Antes sob a responsabilidade do Instituto Florestal, as UCs paulistas, em sua grande maioria, passam a ser geridas pela Fundação Florestal (RAIMUNDO; MATHEUS, 2013).

Podemos fazer uma ponte entre as janelas de oportunidades propostas por Kingdon (op. cit.) com a instituição do SIEFLOR no Estado de São Paulo, em 2006. A Fundação Florestal, que passa a gerir a grande maioria das UCs paulistas, inicia o processo de elaboração e implementação dos planos de manejos e da imposição de formação dos conselhos gestores para as UCs do Estado. Antes do SIEFLOR, eram poucas as UCs que contavam não apenas com tais planos, mas também com conselhos gestores, e a partir do SIEFLOR vê-se o princípio da abertura governamental para processos com abordagens, teoricamente, mais participativas.

A obrigatoriedade de formação dos conselhos gestores apresentou-se num primeiro momento como grande ganho para a abordagem participativa na gestão das UCs de São Paulo, ainda que não tenha ocorrido de maneira uniforme em todas as UCs. Em muitas delas, os conselhos gestores foram criados apenas para cumprir as normas instituídas, 
sem a devida preocupação com a inclusão e a participação real dos atores envolvidos, ou mesmo com os resultados do processo.

De qualquer maneira, os conselhos de parques constituem-se de arenas políticas onde estão representados, em tese, os atores que integram os conflitos referentes ao uso e à ocupação do meio ambiente nessas áreas, e possuem grande potencial para serem espaços que facilitam a minimização e resolução dos conflitos locais.

\subsubsection{E como funcionam os conselhos gestores de parques?}

Apesar dos avanços alcançados no campo das políticas públicas voltadas para UCs no Brasil, são inúmeros os desafios que interferem no seu efetivo funcionamento. Entre esses desafios, conforme afirma Medeiros (2006), estão as limitações financeiras e técnicas e os problemas relacionados às dificuldades de interação das UCs com as dinâmicas locais onde estão localizadas. Com vistas a superar esses conflitos e promover a gestão compartilhada dos recursos naturais, a participação tem sido considerada como pressuposto para o manejo sustentável dos recursos naturais. E os conselhos gestores constituem um dos principais mecanismos de participação no atual contexto da gestão dessas unidades, na medida em que se trata de arenas de interação entre os diferentes atores envolvidos com a conservação das áreas.

Abers e Keck (2008) indicam algumas características comuns a todos os conselhos gestores: são criados por lei; seus membros devem representar grupos específicos; o Estado detém, em geral, metade das cadeiras; a seleção dos membros é variada; e a participação é indireta.

De acordo com as normas, os conselhos são divididos em consultivos e deliberativos. Enquanto os primeiros ficam restritos apenas ao aconselhamento, os segundos têm poder de decisão e voto em determinados assuntos. Conselhos gestores em parques, a exemplo do conselho gestor do PEIC, são prioritariamente consultivos e, portanto, possuem poderes limitados. De acordo com Gohn (2003), as sugestões e decisões que ocorrem em conselhos consultivos podem ou não ser acatadas pelos gestores, já que não há uma obrigação legal de atender às suas demandas. 
No entanto, Santos Júnior, Ribeiro e Azevedo (2004) indicam que ambos os tipos de conselhos têm potencial para influenciar políticas públicas em todas as suas fases, desde a elaboração de diretrizes até o monitoramento das ações em execução. Segundo os autores, um ponto a favor dos conselhos é sua independência com relação à gestão pública, já que sua formação não está condicionada às trocas de gestão.

Para Lane e Maxfield (1966, apud ABERS e KECK, 2010, p.108), os conselhos são espaços importantes do desenvolvimento de relações fecundas entre pessoas que não se relacionariam de outra maneira. Os autores definem relações fecundas como o tipo de interação que surge de relações entre atores de diferentes perspectivas em uma mesma arena, muito mais pautado pelas relações concretas que surgem entre os atores do que por seus interesses e ideias. Essa inovação, de acordo com Abers e Keck (2010), "transforma a capacidade dos atores em influenciar a vida social", na medida em que a participação acaba possibilitando uma transformação do cidadão em relação a seu papel político.

Ainda que apresente muitos limites, o conselho pode ser considerado como um mecanismo de participação dos atores na gestão das UCs. Trata-se de um espaço que dá voz aos atores e onde os conflitos são postos em discussão. Sobre esse assunto, Irving (2006) afirma que os conselhos devem ser encarados como espaços de engajamento da sociedade no planejamento e gestão das unidades de conservação, e, portanto, um mecanismo de participação, controle social e espaço de exercício da cidadania. De acordo com a autora, trata-se de uma instância em potencial para que se alcancem a governança e o exercício da cidadania.

Para alguns atores, o que confere legitimidade a um conselho, seja ele consultivo ou deliberativo, é o modo como os conselheiros se colocam frente às decisões tomadas pelos gestores.

Rodrigues aponta que, apesar de ser consultivo desde sua formação, na prática, o conselho gestor do PEIC teve poderes deliberativos em diversos momentos de sua história, a exemplo de sua influência nas decisões relacionadas ao ordenamento da área do PEIC durante a elaboração do Plano de Manejo (RODRIGUES, 2008).

De acordo com Botelho (2009), um conselho pode alcançar poderes deliberativos, mesmo sendo consultivo, se contar com algumas características importantes, como 
atores com representatividade, abertura de participação por parte do gestor e a forma como os assuntos são tratados e decididos pelos conselheiros e pela gestão.

Assim, um conselho consultivo pode representar um espaço de diálogo e colocar em pauta diferentes interesses de forma tal que esta instância interfira na decisão sobre a gestão da UC, mesmo que não tenha caráter deliberativo (BOTELHO, 2009, p. 54).

A questão sobre a representatividade dentro dos conselhos tem sido objeto de estudo de muitos pesquisadores. Os participantes não estatais representam a sociedade civil organizada e representam em geral organizações diversas. Alguns estudos têm encontrado pouca evidência de que os conselhos de fato contribuem para dar voz a excluídos e minorias. A justificativa é a de que os conselheiros, em geral, não são representativos das classes populares, além de ter ligações frágeis com os grupos que deveriam representar e serem em geral funcionários com pouco poder dentro das organizações: "os conselheiros não governamentais têm encontrado pouco respaldo e acompanhamento de suas ações por parte das entidades que representam" (ABERS e KECK, 2010 p. 65).

Vaz (2011) questiona a legitimidade dos atores que atuam nos conselhos e que, de alguma maneira, podem influenciar as deliberações e processos de decisão. 0 autor argumenta que os conselheiros não representam a sociedade como um todo, mas sim grupos organizados específicos, com interesses próprios. Sobre isso, Avritzer (2007) afirma que a legitimidade da representação está relacionada muito mais à representação de temas de interesse do que de pessoas ou perspectivas específicas.

Outro problema apontado por Abers e Keck (2010) é o próprio poder público, na medida em que são os órgãos governamentais que controlam as agendas dos conselhos, o que reduz a possibilidade de interação política. Segundo os autores, os governos têm grande dificuldade em conferir poder efetivo ao conselho, mesmo quando têm nas mãos o controle do processo decisório.

No caso dos conselhos gestores de parques, por exemplo, a presidência é dada, por norma ${ }^{9}$, para o próprio gestor da unidade, que define qual será a pauta e quais os

\footnotetext{
9 Sistema Nacional de Unidades de Conservação - SNUC, 2000. Artigo 29: “Cada unidade de conservação do grupo de Proteção Integral disporá de um Conselho Consultivo, presidido pelo órgão responsável por sua administração e constituído por representantes de órgãos públicos, de organizações da sociedade civil, por proprietários de terras localizadas em Refúgio de Vida Silvestre ou Monumento Natural, quando
} 
assuntos que entram ou não na discussão das reuniões. Sobretudo, a posição do órgão gestor e do gestor, em especial, é crucial na maneira como se dará a participação dos representantes nos processos decisórios. Ainda que a participação esteja garantida pelo SNUC, a decisão final de inseri-la no âmbito da gestão da unidade de conservação ainda depende da vontade política do órgão gestor. A atuação do gestor, no caso específico do PEIC, foi um dos fatores que influenciaram os rumos do conselho na direção da gestão participativa.

Considerado por muitos autores como os verdadeiros implementadores das políticas públicas, os burocratas de rua, segundo Lipski (apud MEYERS, 2010, p. 250), são os administradores públicos que dialogam diretamente com os cidadãos. Meyers afirma que os burocratas de nível de rua têm oportunidade de influenciar de fato a execução das políticas, na medida em que são os verdadeiros responsáveis pela implementação das políticas públicas, sendo essenciais nas atividades centrais dos órgãos públicos, desde "a determinação da elegibilidade do programa à alocação dos benefícios, o julgamento de conformidade com as normas, a imposição de sanções e a isenção de penalidades a indivíduos e empresas" (MEYERS, 2010, p. 250).

Tal configuração confere a esses burocratas um grande poder de discricionariedade. De acordo com Ham e Hill (1984, Apud SUBRATS, 2006), a discricionariedade existe quando um funcionário tem um nível de poder que permite a ele escolher entre diferentes alternativas de ação. 0 burocrata, portanto, tem a arbitrariedade a seu favor para poder escolher, dentro das normas legais estabelecidas, qual implementar ou não. Meyers (2010) ainda complementa ao dizer que, por conta de sua posição intermediária entre o Estado e o cidadão, a influência exercida por esses trabalhadores da linha de frente supera sua autoridade formal. Eles não apenas executam, mas moldam ativamente os resultados das políticas, e, "por meio de sua rotina e das decisões que tomam, esses trabalhadores, em realidade, produzem políticas públicas tal como os cidadãos as experimentam" (MEYERS, 2010, p. 251).

Essa importância dos burocratas de rua se reflete em quase todas as unidades de conservação do Estado de São Paulo, onde não é possível estabelecer um padrão de

for o caso, e, na hipótese prevista no $\S 2$ o do art. 42, das populações tradicionais residentes, conforme se dispuser em regulamento e no ato de criação da unidade." 
conduta do gestor em relação ao tema participação, condicionada ao perfil do próprio gestor.

Logo no início da formação do conselho gestor do PEIC, a atuação do gestor Marcos Campolim foi fundamental para garantir a participação das comunidades tradicionais nas decisões relacionadas ao ordenamento territorial da UC, já que na mesma época o parque estava em fase de elaboração do Plano de Manejo. Diferentemente do que ocorreu nas outras UCs do Estado que passavam pelo mesmo processo de elaboração de Plano de Manejo, o PEIC foi o único que possibilitou essa abertura para a participação das comunidades no processo de planejamento e ordenamento (RODRIGUES, 2001; MARINHO, 2013).

De acordo com Côrtes (2007), tem proliferado a quantidade de estudos e pesquisas que analisam as condições que viabilizariam o êxito na participação em conselhos gestores. Em primeiro lugar, considera-se que a existência desses fóruns e arenas é condição primeira para que os participantes possam se envolver nas decisões. No entanto, a autora reforça que a formação desses canais participativos não garante que os participantes de fato participem no processo de decisão de determinada política pública, na medida em que cada um pode optar por se envolver ou não, e mesmo esse envolvimento pode "redundar em manipulação, consulta ou somente o acesso à informação" (op. cit., p. 127).

Para Marques (2010), um desenho institucional que viabilize a inclusão política envolve a existência de canais participativos adequados, a exemplo de fóruns, câmaras e audiências públicas; motivação para participar, que se relaciona à satisfação e à confiança nas instituições, bem como a convicção de que a participação será considerada; além de algumas habilidades necessárias, como acesso à informação de qualidade e desenvolvimento de educação formal.

Caso os participantes resolvam se envolver de fato, a efetividade e a constância desse envolvimento vai depender da capacidade de organização das coletividades e grupos sociais nos quais os participantes estão envolvidos. Dessa maneira, não basta participar. É preciso estar num contexto propício à participação.

O desenho institucional é de suma importância para efetivar a inclusão. Para Avritzer (2007), a análise do desenho institucional está relacionada às regras existentes nessas 
instituições, as quais regulam seu funcionamento e condicionam a participação e deliberação que ocorrem no seu interior. $\mathrm{O}$ autor pontua três aspectos que influenciam o desenho: o modo como a participação se organiza, a forma como o Estado se relaciona com a participação e a maneira como as leis exigem do governo a implementação ou não da participação.

Sobre isso, Rodrigues atenta para a importância de analisar a participação sob a ótica da emancipação enquanto negociação entre sujeitos, implicando no diálogo constante entre os diversos setores e as diversas esferas da vida social. Daí a importância de se analisar os acordos coletivos, tanto formais quanto informais, empreendidos entre os diversos atores.

A participação, nesse sentido, pode ser vista como um processo contínuo de aprendizado coletivo entre vários sujeitos, dos quais se requer uma mudança de mentalidade que se dá no processo de negociação/comunicação, ou seja, no desenrolar do próprio processo de aprendizagem social (RODRIGUES, 2001, p. 244).

No que se refere aos processos mal concebidos, além de apresentarem resultados inadequados, aumentam o sentimento de descrença das comunidades em relação a seu poder de participação na solução de problemas e nas ações coletivas. A falta de credibilidade pode impedir que a participação seja instrumento para estabelecer relações de confiança entre os atores sociais e políticos, destruindo sua eficácia como mecanismo para a acumulação de capital social (BANDEIRA, 1999).

Bandeira (1999) reforça que os mecanismos participativos não devem ser encarados como processos infalíveis capazes de fornecer soluções para qualquer situação. 0 autor argumenta que é preciso analisar cada caso, considerando suas especificidades, como o grau de capacitação da comunidade, sua capacidade de integração e abertura para o diálogo, assim como as particularidades de cada um dos problemas, que podem exigir soluções que envolvam ações mais urgentes, por exemplo.

A necessidade de compreensão dos arranjos institucionais dos conselhos gestores reflete a complexidade que envolve a gestão de unidades de conservação e, em especial, as que contemplam moradores em seus limites. Daí vem a necessidade de entender não apenas como os conselhos estão organizados, mas sobretudo quais os elementos que 
influenciam a participação dos conselheiros e sua verdadeira inclusão na gestão das unidades.

\subsection{Gestão dos recursos naturais e desenho institucional - um outro modo de gerir os recursos}

Como já mencionado no capítulo anterior, a participação tem sido destacada como importante elemento na gestão de áreas protegidas, tanto por parte de pesquisadores quanto do próprio poder público e da sociedade civil. A princípio, considera-se nessa premissa a ideia de que as comunidades estabelecem relações de uso harmonioso com os recursos naturais.

Alguns autores denominam como recursos de uso comum, ou commons, os recursos naturais como florestas, solos, fauna selvagem e águas marinhas e continentais (OSTROM, 1990; DIEGUES 2001; BERKES 2005; SIMÕES, 2010). Esses recursos compartilham duas características em comum: os altos custos de exclusão, ou seja, os custos para evitar que qualquer indivíduo tenha acesso à exploração do recurso, e a subtralidade, que envolve a capacidade de cada usuário de subtrair o recurso do bemestar do outro. Essa última é fonte de inúmeros conflitos que envolvem a racionalidade individual e a coletiva, já que, quando se trata de recurso natural, a exploração por um usuário afeta a habilidade de outro para explorar o mesmo recurso (FEENY et al, 1990).

O debate a respeito dos commons tem início em 1968, com um artigo de Garret Hardin, publicado na revista científica Science intitulado "A Tragédia dos Comuns". A partir desse artigo, o autor fica conhecido internacionalmente por afirmar que a degradação dos recursos naturais seria inevitável, caso as propriedades comuns não fossem revertidas em propriedades privadas, ou ainda que houvesse normas claramente definidas pelo poder público para o seu uso. Hardin destaca os riscos da destruição irreversível dos recursos naturais de uso compartilhado, a partir de uma fábula de pastores ingleses que acabam tomando decisões puramente econômicas e individualistas para aumentar seus rebanhos, excedendo a capacidade de suporte de suas áreas de pastagem. A fábula explicita que, apesar dos lucros serem individuais, os 
prejuízos acabam sendo assumidos por todo mundo. A hipótese defendida por Hardin coloca em primeiro plano os impulsos que apontam no sentido da busca egoísta de vantagens pessoais, em detrimento aos interesses relacionados ao bem comum (VIEIRA et al, 2005).

Para Hardin, havia apenas duas saídas para assegurar a perenidade dos recursos naturais: a privatização ou o controle governamental. Suas afirmações partem do pressuposto de que os usuários dos recursos comuns são incapazes de estabelecer relações e acordos para o manejo sustentável desses recursos. Goldman faz um breve resumo sobre a teoria:

O que propunham, e ainda propõem, é a substituição das instituições comunais (nas quais reinariam indivíduos descompromissados) pela propriedade privada e por maiores imposições governamentais, a fim de reverter as ações da maioria que, cegamente, acha-se livre para predar pastagens, consumir mais recursos do que devem e criar mais gado do que podem (GOLDMAN, 2001, p. 48).

Contrariando as ideias defendidas por Hardin, surgem autores que afirmam que tal tragédia nem sempre se confirma no âmbito dos recursos de uso comum. Por meio de exemplos práticos colhidos pelo mundo, Ostrom (1990) afirma que os novos arranjos que acabaram por substituir os regimes de propriedade comum não foram efetivos para promover o manejo sustentável dos recursos, seja na forma privada ou pública. Em muitos casos em que as comunidades foram expulsas do território, os novos proprietários não foram capazes de manter o manejo sustentável dos recursos naturais, causando sérios problemas de degradação e perda de biodiversidade (OSTROM, 1990; DIEGUES, 2001; ABRAMOVAY, 2002).

A autora aponta que, em muitos casos em que a propriedade foi transferida de comunidades tradicionais para outros grupos, acabou-se observando a transformação de usuários conscientes em verdadeiros caçadores ilegais. No Estado de São Paulo, por exemplo, há inúmeras unidades de conservação que foram criadas, e as comunidades que viviam nos limites das áreas protegidas, ou mesmo no seu entorno, acabaram sendo marginalizadas, recorrendo muitas vezes a atividades ilegais de caça, coleta de palmito e derrubada de árvores.

A concepção de Hardin serviu de base para muitas políticas públicas voltadas a áreas protegidas no mundo todo e passou a integrar as políticas públicas de muitos países, 
sendo inseridas na forma de afirmação científica na legislação de florestas, áreas de pastagem e de pesca, as quais acabaram sendo transferidas para o controle estatal (DIETZ et al, 2003). De acordo com Vieira et al (2005), o argumento de Hardin ganhou notoriedade com base na confusão entre as noções de propriedade comum e livre acesso. Pesquisas demonstraram que a natureza coletiva da propriedade não implica necessariamente a condição de livre acesso. Os autores reforçam que, ao passo em que certos modos tradicionais de gestão tenderiam a submeter as atividades de exploração dos recursos considerando a variabilidade dos sistemas vivos, nos regimes de apropriação privada, consideram-se prioritariamente os cálculos econômicos reducionistas, "gerador de efeitos perversos" (VIEIRA et al, 2005, p. 30).

A tragédia dos bens comunais que Hardin preconizava se dirigia muito mais aos bens de livre acesso, sem quaisquer regras de uso, do que propriamente aos regimes de propriedade comum. Como afirma Ostrom (1990), o que se observou na prática foi muito mais a efetivação do livre acesso, devido principalmente à falta de estratégias como consequência da ausência de informações específicas sobre as realidades e contextos socioeconômicos das localidades. Mckean e Ostrom explicitam essa problemática na confusão entre propriedade comum e livre acesso:

Estranhamente, o termo propriedade comum parece ter siso apropriado
como referindo-se à ausência de propriedade ou recursos de livre
acesso - aos quais direitos e responsabilidades não tenham sido
definidos. (...) em regimes de propriedade comum, um grupo particular
de indivíduos divide os direitos de acesso aos recursos, assim
caracterizando uma forma de propriedade - ao invés de sua ausência.
Em outras palavras, existem direitos, e estes são comuns a um
determinado grupo de usuários e não a todos. Dessa maneira, a
propriedade comum não se caracteriza por acesso livre a todos, mas
como acesso limitado a um grupo específico de usuários que possuem
direitos comuns (MCKEAN e OSTROM, 2001, p. 80-81). Para entender melhor essa conceituação de regimes de apropriação, diversos autores dividem os recursos comuns em quatro tipos: livre acesso, propriedade privada, propriedade comunal e propriedade estatal (Quadro 1). 
Quadro 1 - Definição dos regimes de propriedade comum

\begin{tabular}{ll}
\hline Regimes de apropriação dos recursos comuns \\
\hline Livre acesso & $\begin{array}{l}\text { Ausência de direitos de propriedade bem definidos. O acesso ao } \\
\text { recurso não é regulado, mas livre e aberto a qualquer indivíduo. }\end{array}$ \\
\hline Propriedade privada & $\begin{array}{l}\text { Direitos de exploração e regulação da exploração são delegados } \\
\text { a terceiros (indivíduos ou empresas). Em geral, são } \\
\text { reconhecidos e impostos pelo Estado, além de serem exclusivos } \\
\text { e transferíveis. }\end{array}$ \\
\hline Propriedade comunal ou & $\begin{array}{l}\text { Referem-se aos arranjos de direitos de propriedade nos quais } \\
\text { propriedade comum }\end{array}$ \\
& $\begin{array}{l}\text { seu usuários compartilham os direitos e responsabilidades pelo } \\
\text { se a ação de indivíduos externos aos mesmo tempo em que } \\
\text { regulam o uso por membros da própria comunidade. Os direitos } \\
\text { de acesso e uso aos recursos não são exclusivos e transferíveis, } \\
\text { mas sim igualitários. }\end{array}$ \\
\hline Propriedade estatal & $\begin{array}{l}\text { Os direitos aos recursos são exclusivos do Estado, que decide o } \\
\text { acesso aos recursos e a natureza da exploração. O Estado nesse } \\
\text { caso, possui poderes coercitivos de imposição. }\end{array}$ \\
\hline
\end{tabular}

Fonte: Adaptado de Ostrom, 1990.

Em contextos reais, observa-se a sobreposição ou conjugação de dois ou mais tipos de tipologia de recurso comum em um mesmo território, alterando o equilíbrio dinâmico que teriam, em tese, caso estivessem restritos a apenas um tipo. Um exemplo dessa sobreposição de regimes é justamente a instituição de áreas protegidas pelo poder público, inclusive em áreas já ocupadas por comunidades tradicionais, por exemplo, causando inúmeros conflitos no que se refere aos direitos de uso das propriedades.

O PEIC é um exemplo claro dessa sobreposição de regimes de apropriação em um mesmo território. Trata-se de um parque estadual e, portanto, propriedade estatal, sob responsabilidade do estado de São Paulo. Nele, estão inseridas comunidades tradicionais caiçaras que conquistaram ao longo do tempo alguns direitos de uso coletivo compartilhado com regras próprias, que se enquadram no tipo de regime de propriedade comum ou comunal. Também observamos a propriedade privada, na medida em que alguns moradores possuem estabelecimentos turísticos próprios, de gestão individual e familiar. Por fim, antes de se tornar parque, em 1962, também havia muitas áreas sem quaisquer regras e direitos de propriedade, que poderiam ser caracterizadas como de livre acesso. Observam-se, portanto, nos dias atuais, três tipos de regimes de apropriação em um mesmo território, o que por si só já poderia ser fonte de inúmeros conflitos locais. 
A base dos estudos analisados por Ostrom (1990) tem seu foco nos regimes de propriedade comum. Para caracterizar melhor os recursos de bem comum ou propriedades comunais, a autora elenca algumas características que são comuns a esse tipo de propriedade: fronteiras (territórios) definidas, mecanismos de escolhas coletivas, monitoramento do uso dos recursos naturais pelos comunitários, sanções aos que desobedecem às regras, mecanismos de resolução de conflitos, reconhecimento mínimo do direito a se organizar socialmente.

Por meio de estudos empíricos realizados no mundo todo, a autora demonstrou a importância da diversidade institucional para a resiliência do manejo sustentável dos recursos naturais. Na maioria dos casos analisados pela autora, as próprias comunidades conseguiram gerenciar regimes de propriedade coletiva ou propriedades comunais com regras de manejo próprias. Em muitos casos, as próprias dinâmicas locais acabam criando condições para a regulação do uso dos recursos comuns dentro da própria coletividade, excluindo os agentes externos. Segundo Diegues (2001), os exemplos oferecidos por Ostrom ilustram as habilidades e o grande potencial das comunidades em organizar e monitorar o uso dos recursos pelos seus membros, em regular o direito de uso entre os membros e ainda manter o uso sustentável dos seus recursos.

\subsubsection{Ação coletiva e Arranjos Institucionais}

As instituições têm papel fundamental no contexto de gestão dos recursos naturais. Em todos os regimes de propriedade e uso de recursos naturais, existem regras de uso que devem ser consideradas pelos atores envolvidos. Ostrom (2001) define as regras de acesso a esses recursos como as instituições que servirão de base para as tomadas de decisão sobre os recursos, ou seja, determinam o que é permitido ou não em cada situação, bem como quem pode ou não participar do processo decisório.

A autora reforça que, na Tragédia dos Comuns, Hardin negligencia o papel dos arranjos institucionais que acabam por gerar exclusão e regulação de uso (OSTROM, 2001). Trata-se de fato de uma complexa teia de relações, inerente a qualquer comunidade, 
sendo essencial considerar os arranjos institucionais, a natureza dos recursos, os processos de tomadas de decisão e ainda as interações e relações entre os membros e os recursos e entre os próprios membros da coletividade. Os estudos empíricos demonstraram que as comunidades podem manejar os recursos naturais por meio de decisões que ultrapassam o âmbito das decisões racionais. Ehlers (2003) argumenta que nem sempre os indivíduos maximizam as riquezas, já que o processo de escolha individual pode ser determinado por valores e crenças que nem sempre têm aporte no âmbito da racionalidade.

Observa-se a importância de se considerar o consciente coletivo de comunidades que têm, de fato, essa relação com o meio natural. Sobre isso, Diegues (2001) afirma que nas comunidades, em maior ou menor escala, existe a noção de que os recursos compartilhados devem ser usados de maneira sustentável, já que deles dependem a reprodução social e a sobrevivência da própria comunidade. Autogovernança exige que ação coletiva, conhecimento, vontade e arranjos institucionais de apoio consistentes estejam em sintonia (OSTROM, 2007).

Nesse contexto, Ostrom (2001) sugere a análise dos arranjos institucionais para aferir quais são as regras formais e informais, bem como os acordos coletivos que influenciam o uso sustentável dos recursos de acesso comum pelas comunidades, por meio do Institutional Analysis and Development (IAD). Com base em modelos e elementos de análise, a autora investiga como as instituições influenciam os membros de uma mesma comunidade a interagirem e condicionam as estratégias e ações que envolvem ações coletivas. 0 desafio da autora é justamente entender por que algumas comunidades conseguem se organizar para manejar recursos comuns enquanto outras não conseguem.

Em geral, os arranjos institucionais na gestão de recursos naturais podem ser privados, estatais ou comunais, mas também combinados entre si, sugerindo a necessidade de conexões institucionais por meio da descentralização das tomadas de decisões. Deve haver, portanto, parcerias e compartilhamento de ideias na gestão, ou, como defende Vieira et al (2005), a cogestão, que pode ser entendida como uma estratégia de gestão formal que integra comunidades e governos. Não há um conceito único a respeito dos processos de cogestão, já que o compartilhamento de poder e a participação variam de 
acordo com cada situação e com as relações que são estabelecidas entre os usuários e ambiente (VIEIRA et al, 2005; ARMITAGE et al, 2007).

Alguns autores defendem que transmitir completamente os direitos de uso para comunitários talvez não seja o mais adequado, sendo que o Estado poderia continuar a exercer seu papel de conservação e alocação de recursos entre as comunidades. A gestão compartilhada seria então uma solução viável (PINKERTON, 1989; FEENY et al, 1990).

Na contramão dos princípios de cogestão, cujo pressuposto é o da descentralização, vêse uma centralização excessiva na gestão dos recursos naturais na maioria dos casos em que o Estado assume a responsabilidade pela gestão dos recursos naturais. De acordo com VIEIRA et al (2005), essa centralização não ocorre de maneira uniforme, na medida em que depende dos arranjos institucionais estabelecidos nas diferentes áreas naturais, por diferentes indivíduos ou coletividades. 0 autor ainda afirma que a ausência de legitimação ou reconhecimento de instituições no nível local é um dos fatores que mais dificultam a construção de "instituições robustas".

Para Ostrom, o conceito de instituições robustas está relacionado à perenidade de instituições que conseguem se manter sustentáveis por um longo período de tempo, com mais capacidade para se adaptar e manter sua performance diante de distúrbios (OSTROM, 2005). Para tanto, a autora identifica alguns fatores que influenciam a capacidade de manejo dos recursos comuns pelas comunidades, como a existência de normas, monitoramento e sanções, estratégias, benefícios e custos bem definidos. Esse conjunto de características demanda das comunidades acesso às informações, bem como um ambiente de confiança entre os membros das comunidades, já que requer organização coletiva para a obtenção de benefícios que nem sempre se mostram no curto prazo para os indivíduos.

Estudos realizados por Ostrom (OSTROM; MCKEAN, 2001; OSTROM, 2010; SIMÕES, 2010) apresentam uma série de recomendações para que se alcancem arranjos institucionais de longa duração no manejo de recursos naturais:

1. Limites claramente definidos: fronteira da comunidade para o uso dos recursos de acesso comum deve ser clara, com limites bem definidos e com critérios para o ingresso a grupos de usuários; 
2. Congruência entre apropriação e provisão de regras e condições locais: as regras de uso dos recursos de acesso comum devem ser claras e bem definidas, condicionadas às realidades locais;

3. Os critérios para ingresso a grupos de usuários devem estar claros: os grupos de usuários devem estar cientes e de acordo sobre quem são os membros e quais as normas ou critérios de elegibilidade considerados;

4. Os usuários devem ter o direito de modificar suas regras de uso ao longo do tempo: as regras devem ser flexíveis para que possam se adaptar às demandas que surgem com o passar do tempo e também às próprias mudanças ecológicas;

5. As regras de uso devem corresponder ao que o sistema pode tolerar e devem ser ambientalmente conservadoras para possibilitar margens de erro;

6. As infrações das regras de uso devem ser monitoradas e punidas. As sanções devem ser graduais, de maneira que as infrações aumentem caso o usuário pratique o ato de infração repetidamente;

7. A distribuição de direitos de tomada de decisão e de direitos de uso aos coproprietários dos recursos de uso comum não precisa ser igualitária, mas deve ser justa. Deve haver o reconhecimento mínimo de direitos pelas autoridades governamentais, para organização e de estabelecimento de regras próprias no uso de acesso comum.

8. Métodos baratos e rápidos para a solução de conflitos menores devem ser concebidos: pressupõe-se que seja comum que haja pequenos desentendimentos entre os grupos de usuários, sendo necessário que sejam resolvidos o mais rápido possível;

9. Instituições para o manejo de sistemas muito amplos devem ser estabelecidos, devotando considerável autoridade a pequenos componentes por meio de empreendimentos inter-relacionados.

Ostrom (2010) reforça que os critérios elencados sintetizam os elementos básicos que poderiam afetar a sobrevivência a longo prazo de instituições desenvolvidas por indivíduos ou grupos usuários de recursos de uso comum. No entanto, a autora 
reconhece que arranjos alternativos podem ser muito eficientes e que a flexibilidade é de suma importância para garantir sistemas e arranjos exitosos.

Há o reconhecimento de que, em geral, não há uma aceitação completa por parte de todos os membros das comunidades. No entanto, a autora reforça a importância de construir e manter instituições fortes o suficiente para permitir que haja interesses e agentes conflituosos no processo de ação coletiva. A análise desses princípios elencados anteriormente permite que se faça um diagnóstico do desempenho institucional, a partir da avaliação da capacidade das comunidades na organização coletiva para o manejo de recursos comuns.

Convém destacar ainda que, para além das análises internas à própria coletividade, percebem-se grandes deficiências na atuação do poder público em relação à gestão das áreas naturais, seja por inúmeros problemas técnico-administrativos, seja por incapacidade de resolução de conflitos locais. Abramovay (2001) afirma que essa crise da gestão pública tem levado à proliferação de modelos e teorias que consideram uma gestão compartilhada dos recursos naturais, a exemplo de gestão conjunta do poder público e da sociedade civil, principalmente por organizações comunitárias ou instituições formais. A participação nesse contexto é premissa fundamental para garantir essa gestão compartilhada.

O PEIC tem sido considerado por muitos estudiosos como uma referência em gestão compartilhada, principalmente quando se trata da comunidade do Marujá, considerada também como referência em gestão comunitária (MARINHO, 2013). A compreensão dos elementos que influenciam e, em muitos casos, determinam a participação das três maiores comunidades (e não apenas do Marujá) na gestão do PEIC, seguindo a ótica de análise dos arranjos institucionais de Ostrom (1990), requer compreender os arranjos institucionais, ou seja, quais são os acordos formais e informais estabelecidos nas comunidades e entre as comunidades e a gestão, e como essas interações influenciam o conselho gestor. 


\subsubsection{Modelo de análise: Institutional Analysis and Development Framework / IAD}

De acordo com Ostrom, o termo instituições pode ser definido como "conceitos compartilhados e usados por humanos em repetidas situações que são organizadas por regras, normas e estratégias" (OSTROM, 2007, p. 23). 0 termo refere-se, portanto, às regras, normas e estratégias adotadas por indivíduos ou grupos operando dentro de uma organização. Representam mecanismos que moldam comportamentos em situações entre dois ou mais indivíduos ou grupos. As instituições incluem famílias, igrejas, agências governamentais e a maioria das organizações, desde que sejam definidas de acordo com regras, normas ou estratégias compartilhadas.

O Institutional Analysis and Development Framework (IAD) foi criado por Ostrom como um modelo de análise próprio para o estudo de gestão compartilhada da ação coletiva e recursos ambientais. De acordo com o modelo, as instituições promovem benefícios sociais, na medida em que ajudam indivíduos ou grupos a resolverem dilemas quando as ações individuais racionais acabam por produzir resultados socialmente irracionais. Os arranjos institucionais, portanto, fornecem as bases para evitar que ocorra a Tragédia dos Comuns, previsto por Hardin, e para resolver problemas de bem comum por meio de ações coletivas (CRAWFORD e OSTROM, 1995).

A unidade de análise do IAD é a arena de ação, se diferenciando de outros tipos de análise justamente por ser institucional e ter seu foco nas regras. Esse modelo proposto por Ostrom busca examinar um problema que um grupo de indivíduos enfrenta e as regras que eles adotam frente ao problema. 0 seu processo cíclico requer entendimentos sobre a natureza do problema, a natureza do indivíduo (cultura) e o quadro institucional no qual os indivíduos ou grupos de indivíduos estão imersos (OSTROM, 1990).

A estrutura IAD apresenta como unidade conceitual a arena de ação, onde indivíduos interagem em um espaço social denominado situação de ação. A arena de ação é formada por atores, indivíduos ou grupos, que participam dos processos de discussão e tomada de decisões e buscam garantir que suas preferências sejam consideradas nas decisões. A arena é formada pelos atores e pelas Situações de Ação. Enquanto as características dos atores e da situação de ação definem a arena, as interações e intercâmbios entre os indivíduos ou grupos de indivíduos produzem os resultados do 
arranjo institucional. A partir da arena de ação é possível analisar, prever e explicar os comportamentos no âmbito dos arranjos institucionais.

O ponto de partida para a análise IAD é a identificação dos atores da arena de ação. Para tanto, é importante identificar uma área específica, ainda que possa haver um conjunto diferente de instituições que interagem e atuam sobre ela. Uma arena de ação pode incluir uma ampla variedade de atores, inclusive localizados fora dos limites geográficos pré-determinados, desde que suas decisões afetem de alguma maneira a gestão dessa arena.

0 principal foco de influência das instituições é a situação de ação. As situações de ação são os espaços sociais onde se encontram os atores e onde estes, individualmente ou em grupo, observam as informações, selecionam as ações, interagem e percebem os resultados dessas interações. A utilização das situações de ação, de acordo com Ostrom (1990), possibilita isolar o problema da estrutura que o afeta e propõe explicar as regularidades da ação humana e seus resultados.

Para o estudo proposto, consideraremos a participação como Arena de Ação, enquanto a Situação de Ação escolhida para melhor compor as análises é o Conselho Gestor do PEIC.

A estrutura de uma situação ação possui componentes que permitem a identificação dos atores relevantes, assim como os recursos e as opções disponíveis aos atores. No âmbito do IAD, são sete os componentes da situação ação:

1. Grupo de participantes

2. Posições que cada participante exerce

3. Grupo de ações permitidas

4. Resultados potenciais

5. Nível de controle sobre a escolha

6. Informação disponível

7. Custos e benefícios de ações e resultados.

Situações de ação podem ser eventos temporários ou recorrentes, mas que possibilitem a participação dos atores. As decisões tomadas durante as situações de ação têm resultados efetivos quanto a procedimentos e regras para seu funcionamento. No 
entanto, dependendo do tipo de situação de ação, há decisões que ultrapassam os poderes dos atores e estão nas mãos de outros indivíduos ou instâncias.

O ponto chave para a análise do IAD, de acordo com Ostrom, compreende a identificação das variáveis externas que influenciam a situação de ação. São três variáveis essenciais que influenciam o funcionamento da situação de ação: atributos do mundo físico, atributos da comunidade e as regras usadas pelos indivíduos para ordenar suas relações.

A. Os atributos do mundo físico são as características do recurso e todos os demais aspectos materiais que sejam relevantes que possibilitem a ação dos atores e seus resultados. Afetam o conhecimento e a informação que os atores possuem sobre o recurso. Possuem um efeito sobre outros fatores, em especial sobre as regras usadas pelos apropriadores dos recursos. Trata-se do local de ação dos atores, onde se estabelecem as relações com o meio e com os demais atores, que afetam o estabelecimento e o significado das regras. Para que sejam efetivas, as regras devem ser compatíveis com ambiente físico e biológico onde a arena está inserida.

B. Os atributos da comunidade referem-se aos padrões culturais da comunidade envolvida na situação de ação. Incluem normas de comportamento aceitas, além do nível de entendimento comum sobre as arenas de ação, o grau de homogeneidade das preferências dos atores e a distribuição de recursos entre os membros.

C. As regas em uso, ou instituições, podem ser definidas como os conjuntos de regas que determinam quem tem direito ou não a tomar decisões, quais ações são permitidas ou proibidas, quais as regras de afiliação, quais procedimentos devem ser seguidos, quais informações devem ou não ser facilitadas e quais retribuições são designadas pelos indivíduos segundo suas ações. As interações entre os atores são influenciadas pelas suposições sobre as regras utilizadas para ordenar as relações entre indivíduos ou organizações. É preciso, portanto, entender quais são as regras utilizadas pelos atores para justificar sua ação ou as interações com outros participantes da arena.

Para compreender como uma arena de ação funciona, é preciso entender como as regras formais e informais interagem entre si. As arenas são ligadas por diferentes níveis de 
análise, que podem ser caracterizadas por diferentes níveis de regras. As regras, neste contexto, podem ser entendidas como um conjunto de instruções criadas por um indivíduo ou grupo de pessoas, que estruturam uma situação-ação e produzem resultados em um determinando ambiente, podendo ou não afetar outros indivíduos (OSTROM, 2005). Estão associadas a diferentes níveis de tomada de decisão que funcionam como camadas de análise, conforme Quadro 2.

Quadro 2 - Níveis de tomada de decisão, de acordo com o IAD

\begin{tabular}{lcl}
\hline Regras Operacionais & $\begin{array}{l}\text { Atores interagem sob incentivos para gerar resultados } \\
\text { diretos. Trata-se das decisões sobre quando, onde e como } \\
\text { fazer algo, quem monitora as ações dos outros, como as } \\
\text { ações devem ser monitoradas, que informação deve ser } \\
\text { trocada ou omitida, e quais recompensas e sanções serão } \\
\text { ligadas a combinações de ações e resultados. }\end{array}$ \\
\hline $\begin{array}{l}\text { Regras } \\
\text { coletiva }\end{array}$ & de & escolha \\
& & $\begin{array}{l}\text { As decisões sobre as políticas públicas são repetidamente } \\
\text { tomadas dentro de um conjunto restrito de regras de } \\
\text { escolha coletiva. Influenciam as atividades operacionais } \\
\text { pela determinação de como as regras operacionais podem } \\
\text { ser modificadas e quem pode participar nessa decisão. }\end{array}$ \\
\hline $\begin{array}{l}\text { Regras de } \\
\text { constitucional }\end{array}$ & escolha & $\begin{array}{l}\text { Decisões são tomadas sobre quem é elegível de participar } \\
\text { da formulação de políticas públicas e as regras usadas } \\
\text { para desenvolver e modificar as regras de escolha } \\
\text { coletiva, que acaba por afetar todo o sistema de regras. }\end{array}$ \\
\hline
\end{tabular}

Fonte: Adaptado de Ostrom (1990).

No caso do Conselho Gestor do PEIC, as regras em sua maioria são provenientes das leis já existentes tanto em um âmbito mais macro, a exemplo das leis ambientais e do SNUC, quanto no âmbito mais local, a exemplo do Plano de Manejo e do estatuto e regimento do Conselho Gestor. Por se tratar de uma unidade de conservação com um conselho gestor apenas consultivo, em teoria, o limite de atuação do conselho está muito mais centralizado nas regras operacionais, já que o conselho tem poder de atuação nas questões relacionadas a monitoramento, fiscalização e sanções às regras desobedecidas.

As regras em uso (rules-in-use) utilizadas nas situações de ação podem ser tanto formais quanto informais. As regras formais de uso estão relacionadas à legislação, às decisões do executivo e judiciário, além de contratos formais entre particulares. No caso das regras informais, incluem-se as regras e acordos coletivos que possam ter sido formulados em condições em que não são reconhecidos por lei. Ambas são fundamentais para compreender como funcionam as situações de ação. 
Para Ostrom (2007), além de compreender quais são as regras em funcionamento, é preciso descobrir também a origem dessas regras, pois pode se tratar de regras oriundas de leis ou não. A autora argumenta que, se as regras da lei não são regras em uso, é possível que os atores tentarão evitá-las em vez de obedecê-las. Pinto (2014) reforça que, nos casos de UCs, as regras que estão em vigor podem não ser as regras em uso, e, devido à complexidade de cada caso, existem características das comunidades e das condições físicas locais e materiais que podem criar formas singulares de gestão de cada comunidade.

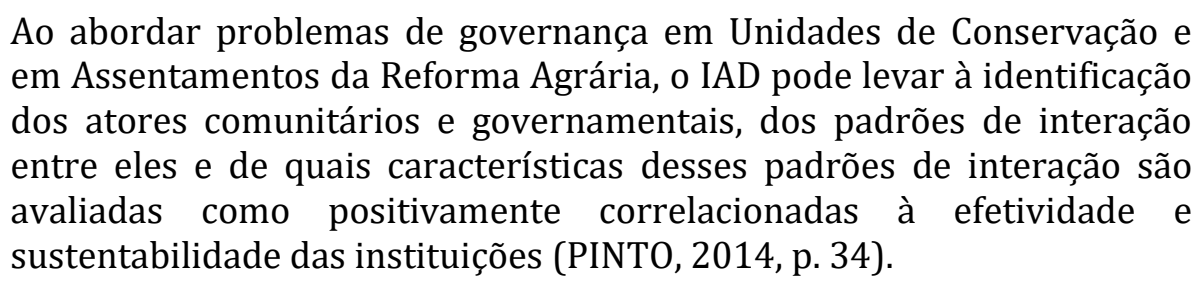

No caso específico das UCs, é preciso atentar para a existência de regras de gestão e acesso, que são definidas, sobretudo localmente, de acordo com as necessidades locais.

Ostrom pondera que a capacidade coletiva de resolver problemas tem algumas limitações, relacionadas em grande parte à falta de confiança entre os atores, à falta de expectativas quanto à confiança mútua e à própria construção da confiança por meio da comunicação e interação constante, e ainda quando os atores não têm autoridade para criar suas próprias instituições autogovernáveis (OSTROM, 1990).

Mesquita e Abreu (2014) reforçam que os atores tomam decisões com base num conhecimento incompleto de todas as possíveis alternativas. Ao longo do tempo, podem adquirir um melhor entendimento para alcançar melhores resultados. Para McGinnis (2011), as preferências de cada ator, assim como as opções disponíveis, são determinadas pelos arranjos institucionais que definem suas posições. Dessa maneira, os processos de decisão são moldados pela posição e interesse definidos ou manifestados nas arenas das escolhas institucionais.

Com base em observações de pesquisas realizadas sobre o IAD, Imperial (1999) observa que arranjos centralizados e hierarquizados nem sempre são a solução, na medida em que arranjos policêntricos e fragmentados aumentam a eficiência do desempenho institucional. 
No entanto, é preciso reforçar que não se trata de um processo estático, mas sim de um processo em constante movimento, pressupondo flexibilidade dos atores para possíveis adequações que se façam necessárias. Os atores podem escolher, individual ou coletivamente, mudar as regras em controle, o que significa também que serão alteradas as relações interorganizacionais presentes no arranjo. As mudanças institucionais abrangem troca de regras, monitoramento ou procedimentos de ação que acabam fazendo com que os atores adotem diferentes estratégias e comportamentos que podem afetar os resultados.

O modelo de análise proposto por Ostrom, conforme Figura 7, envolve um sistema complexo de atores, arranjos e situações que podem ser visualizados no caso do PEIC.

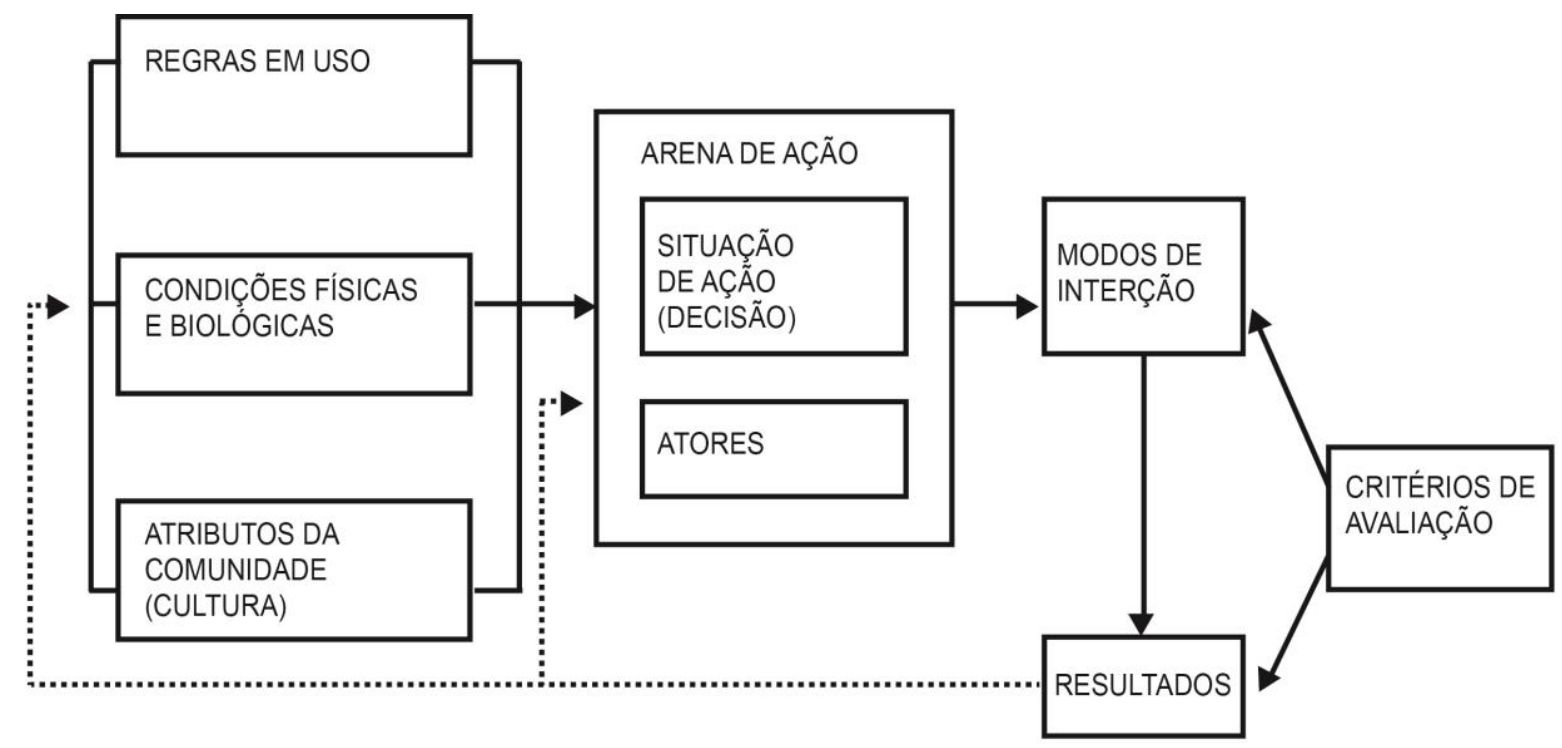

Figura 7 - Arcabouço para Análise Institucional, conforme o IAD Framework Fonte: Adaptado de Ostrom (1990).

Os direitos conquistados pelas comunidades, oriundos de acordos formais e informais feitos ao longo dos anos, são consequência das interações entre os diversos atores envolvidos no processo. Há acordos que envolvem as comunidades como um todo, assim como há acordos que envolvem comunidades específicas. A análise das diferentes realidades em cada uma das comunidades é fundamental para entender os diferentes arranjos. Justamente por comportar tamanha complexidade, o modelo será a base das análises feitas nas três comunidades caiçaras do PEIC e no conselho gestor. 


\section{PROCEDIMENTOS METODOLÓGICOS}

O presente capítulo apresenta as escolhas metodológicas traçadas para o alcance do objetivo proposto pela pesquisa, qual seja o de analisar as possibilidades e conflitos da participação de comunidades tradicionais na gestão do Parque Estadual da Ilha do Cardoso. De maneira que se possa atingir os objetivos geral e específicos apresentados, foram utilizadas técnicas de pesquisa qualitativa. Segundo Thiolent (2007, p. 84), a perspectiva socioambiental requer uma abordagem sistêmica, "não limitada à análise de variáveis isoladas, mas de um modo capaz de apreender o todo e as partes nas suas relações com o todo, enxergando a complexidade que resulta da interação entre as partes".

Pretende-se analisar os arranjos institucionais presentes em cada uma das comunidades escolhidas, bem como sua influência nos diferentes níveis de participação das comunidades no conselho gestor. A abordagem institucional com foco no conselho gestor foi escolhida pela importância desse espaço no contexto da gestão do parque e da participação das comunidades.

O PEIC conta atualmente com oito comunidades caiçaras em seu interior. No entanto, optou-se por fazer um recorte das quatro comunidades que possuem uma participação mais assídua no conselho gestor, a saber: Marujá, Enseada da Baleia, Itacuruçá e Pereirinha. No contexto do estudo, as comunidades do Itacuruçá e Pereirinha serão consideradas como uma comunidade, na medida em que se representam por meio de uma mesma associação, a Associação dos Moradores do Itacuruçá e Pereirinha (AMOIP).

A seguir serão apresentados o modelo definido como base para as análises e as técnicas de pesquisa escolhidas. 


\subsection{Definição do modelo de análise}

O modelo IAD é uma ferramenta que propõe investigar como os atributos do mundo físico, os atributos das comunidades e as regras em uso afetam os resultados de uma organização ou instituição. Trata-se de uma ferramenta cuja abordagem está centralizada em atores e instituições, sendo útil para a análise de problemas onde os atores encontram-se em situações complexas, como é o caso dos conflitos relacionados à utilização de recursos naturais. Em linhas gerais, busca compreender um problema que um grupo de indivíduos enfrenta e as regras que adota frente a esse problema, de maneira a fornecer uma ferramenta para a análise teórica e empírica (OSTROM, 1990).

Justamente por considerar as diferentes variáveis que interagem em sistemas complexos, tem sido utilizado nas análises de gestão de recursos naturais e em análises de gestão compartilhada e cogestão.

No caso da presente pesquisa, o IAD nos auxilia a compreender de que forma os arranjos institucionais das comunidades e as regras criadas em anos de interação das comunidades com a gestão do parque interferem não apenas na gestão da unidade de conservação propriamente dita, mas também na resolução dos conflitos associados à criação do parque e à permanência das comunidades.

A arena de ação proposta pelo modelo será a participação na gestão do Parque Estadual da Ilha do Cardoso, enquanto a situação de ação escolhida para delimitar o campo de análise será o Conselho Gestor do PEIC. A opção pela escolha do conselho gestor se deu por sua importância no contexto da gestão do parque e da participação das comunidades.

Convém destacar que o modelo desenvolvido por Ostrom (1990) foi escolhido como fio condutor da pesquisa, mas foi adaptado para a realidade da gestão do parque e do conselho gestor, de maneira que pudesse atender as finalidades desta pesquisa, conforme Figura 8. 


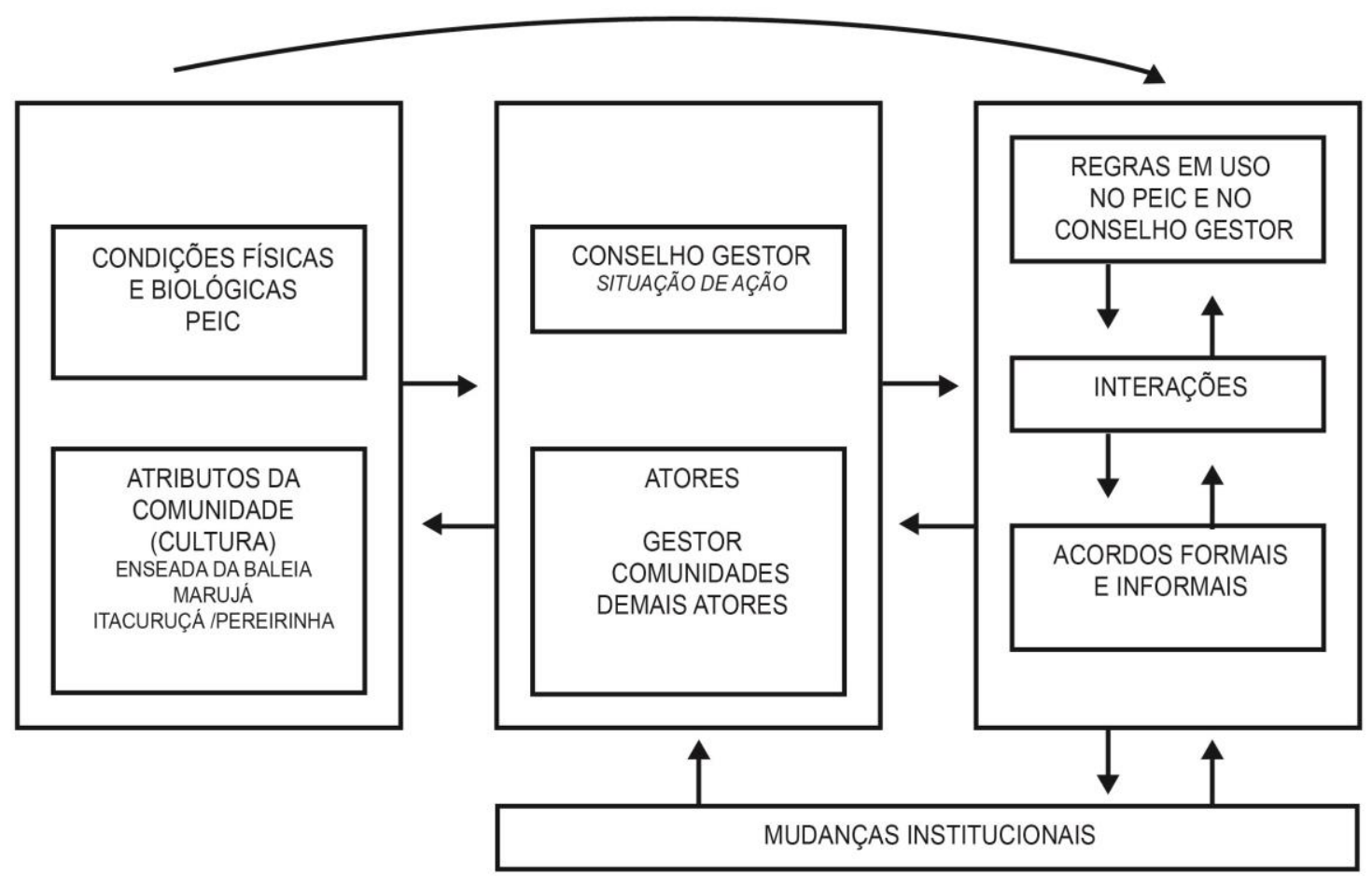

Figura 8 - Modelo de Análise: Adaptado de Institutional Analysis and Development Framework

Fonte: Adaptado pela autora.

Reitera-se que, de acordo com os objetivos estabelecidos, se trata de uma análise realizada com um recorte específico de tempo (presente) e atores (quatro comunidades), de maneira que se possa analisar o desenho atual do conselho e da participação das comunidades escolhidas para o estudo. Não há intenção de fazer uma análise do desenho do conselho ao longo dos anos.

A seguir serão apresentadas as técnicas de pesquisa utilizadas.

\subsection{Pesquisa documental e bibliográfica}

A etapa inicial consistiu na consulta a livros, documentos, pesquisas científicas, teses e dissertações, que, num primeiro momento, serviram para a construção do referencial teórico e forneceram as bases que nortearam a pesquisa. 
Além das bases teóricas, já referenciadas no capítulo de Abordagem Teórico Conceitual, foram consultados materiais específicos relacionados a normativas que afetam diretamente a gestão do Parque Estadual da Ilha do Cardoso, a exemplo de normas, leis e decretos ambientais, e também àquelas relativas a comunidades tradicionais, em especial as caiçaras.

No âmbito dos documentos específicos do PEIC, foram consultados o Plano de Manejo aprovado pelo CONSEMA em 2001; Estatuto e Regimento Interno do Conselho Gestor do PEIC; Atas das reuniões do Conselho Gestor; Laudo Antropológico das Comunidades do PEIC; Laudos do Instituto Geológico com foco no processo de erosão na Enseada da Baleia; Estatuto e Regimento Interno da Associação dos Moradores do Marujá (AMOMAR); Estatuto da Associação dos Moradores do Itacuruçá e Pereirinha (AMOIP); Estatuto da Associação dos Moradores da Enseada da Baleia (AMEB); além de outros documentos correlatos que se mostraram pertinentes durante a execução da pesquisa.

\subsection{Entrevistas}

A técnica de entrevista qualitativa em profundidade pressupõe o uso de um roteiro de entrevista semiestruturado, do qual devem manter-se fixos somente os temas-chave. Os questionamentos complementares gozam de relativa flexibilidade, podendo ter sua ordem alterada, ou mesmo serem suprimidos ou adicionados, de acordo com o decorrer de cada entrevista.

A amostra foi composta por membros das comunidades analisadas, dois gestores (sendo um atual e um antigo) e demais atores identificados como figuras-chave para compreender o desenho institucional do conselho e os arranjos institucionais das comunidades, conforme Quadro 3. As entrevistas foram realizadas em 2014 e 2015. 
Quadro 3 - Lista de entrevistados

\begin{tabular}{ll}
\hline Instituição / Comunidade & Relação com o PEIC \\
\hline Fundação Florestal - PEIC & Atual gestor do PEIC, desde agosto de 2014. \\
\hline Instituto Florestal & Ex gestor do PEIC, de 1996 a 2007. \\
\hline Comunidade do Marujá & Morador tradicional do Marujá, líder da comunidade. \\
\cline { 2 - 2 } & $\begin{array}{l}\text { Morador tradicional do Marujá, presidente da AMOMAR, } \\
\text { conselheiro no Conselho Gestor do PEIC. }\end{array}$ \\
\cline { 2 - 2 } & Morador tradicional do Marujá. \\
\cline { 2 - 2 } eomunidades do Itacuruçá & Moradora tradicional do Marujá. \\
\hline Pereirinha & $\begin{array}{l}\text { Moradora tradicional do Itacuruçá, presidente da AMOIP, } \\
\text { conselheira no Conselho Gestor do PEIC. }\end{array}$ \\
\cline { 2 - 2 } & $\begin{array}{l}\text { Moradora tradicional do Itacuruçá, ex presidente da AMOIP e ex } \\
\text { conselheira no Conselho Gestor do PEIC. }\end{array}$ \\
\cline { 2 - 2 } & $\begin{array}{l}\text { Morador tradicional do Itacuruçá e ex conselheiro no Conselho } \\
\text { Gestor do PEIC. }\end{array}$ \\
\cline { 2 - 2 } & Morador tradicional do Itacuruçá. \\
\hline Bomunidade da Enseada da & $\begin{array}{l}\text { Moradora tradicional da Enseada da Baleia, presidente da AMEB, } \\
\text { conselheira no CG. }\end{array}$ \\
\cline { 2 - 2 } Moleia & Moradora tradicional da Enseada da Baleia, e conselheira no CG. \\
\cline { 2 - 2 } & $\begin{array}{l}\text { Morador tradicional da Enseada da Baleia e guarda parque do } \\
\text { PEIC. }\end{array}$ \\
\hline Sem vínculo & $\begin{array}{l}\text { Ex conselheira no Conselho Gestor do PEIC, ex colaboradora da } \\
\text { Rede Cananéia, e participante assídua nas reuniões do Conselho } \\
\text { Gestor como ouvinte. }\end{array}$ \\
\hline
\end{tabular}

Fonte: Autora.

As entrevistas colaboraram na investigação de aspectos mais valorativos dos temas que o compõem, buscando identificar atitudes, comportamentos e tendências nas áreas de estudo. Objetivaram compreender, dessa maneira, os arranjos institucionais, tanto no âmbito das comunidades analisadas, quanto no âmbito do conselho gestor, a partir da identificação e análise dos níveis de participação das comunidades na gestão do parque, analisando sua relação com os diferentes arranjos institucionais formados em cada uma delas.

As entrevistadas foram gravadas com a autorização dos entrevistados e posteriormente transcritas. A análise das entrevistas foi feita a partir do agrupamento das respostas nos temas específicos que nortearam a pesquisa. 


\subsection{Participação nas reuniões do Conselho Gestor do PEIC}

A observação e contato direto com a população estudada permitem que se possa compreender as dimensões culturais, econômicas e sociais, necessárias ao estudo dos impactos nos modos de vida das comunidades. Trata-se de um recurso adicional a ser utilizado durante a coleta de dados, de maneira que se possa obter dados não informados durante as entrevistas.

A pesquisadora acompanhou nove reuniões do conselho gestor, compreendidas em setembro de 2014, entre julho de 2015 e janeiro de 2016 e em junho de 2016. Também foram acompanhadas outras reuniões pertinentes no âmbito de Grupos de Trabalho e Câmaras Temáticas do conselho gestor.

Em cada um dos eventos, os registros foram feitos em um caderno de anotações, considerando alguns aspectos essenciais para os objetivos propostos pela pesquisa: comportamento dos atores, interações, mecanismos de comunicação, participação e votação, abertura para o diálogo, condução das reuniões, entre outros assuntos pertinentes.

\subsection{Visitas às comunidades}

Durante a realização da pesquisa, foram feitas algumas visitas às comunidades, de maneira a complementar e confrontar os dados obtidos durante as entrevistas. Foi utilizada também a técnica de observação não participante. As visitas constituíram etapa complementar às demais empreendidas, mas foram importantes para o reconhecimento do espaço das comunidades e compreensão das interações e arranjos institucionais, principalmente no âmbito interno das comunidades. 


\subsection{Análise dos resultados}

A etapa final da pesquisa envolveu a análise dos resultados a partir dos objetivos propostos. As entrevistas foram sistematizadas pelas transcrições e organizadas em um documento único, agrupadas de acordo com os temas específicos desenhados na estrutura das análises. Às informações coletadas nas entrevistadas foram acrescidas as informações obtidas durante as reuniões do conselho gestor e as visitas às comunidades. A compilação dos dados foi fundamental para a análise final dos resultados, permitindo a elaboração de generalizações, confrontadas com a triangulação dos dados obtidos.

Em linhas gerais, a análise buscou compreender os seguintes aspectos: arranjos institucionais em cada uma das comunidades; histórico e funcionamento do conselho gestor; participação das comunidades nas reuniões do conselho e os elementos que influenciam tal participação; papel do gestor como mediador das reuniões; papel do gestor na participação das comunidades na gestão do parque; interações existentes entre conselheiros, comunidades e gestor; acordos formais e informais, bem como regras de uso utilizadas no interior das comunidades e no âmbito da gestão do parque; consequências das mudanças institucionais na participação das comunidades; o conselho como espaço democrático de participação; as possibilidades reais de participação das comunidades na gestão de uma unidade de conservação e seus impactos na preservação ambiental e nos conflitos com as comunidades; análise da gestão compartilhada de recursos como possibilidade de minimização de conflitos locais. 


\section{PARTICIPAÇÃO DAS COMUNIDAdES NA GESTÃo DO PARQUE ESTADUAL DA ILHA DO CARDOSO}

As análises a seguir foram elaboradas de acordo com o modelo adaptado de Ostrom (1990), o Institutional Analysis and Development Framework. A (1) primeira parte apresenta cada uma das comunidades estudadas, a partir da identificação e análise dos arranjos institucionais presentes em cada uma delas, estruturados com base nos seguintes tópicos: contexto histórico, modos de organização (cultura), regras internas e participação no conselho. A (2) segunda parte tem foco no detalhamento a respeito do Conselho Gestor do PEIC, abrangendo o seu surgimento, as normativas relacionadas a ele e o perfil dos participantes. A (3) terceira parte aborda as regras em uso no PEIC e no Conselho Gestor. A (4) quarta parte contempla algumas análises a respeito do funcionamento do conselho, enquanto a (5) quinta parte está focada nas mudanças institucionais e nos impactos que causam no funcionamento do conselho e na participação das comunidades. Por fim, a (6) sexta e última parte compreende a análise da robustez do conselho gestor, de acordo com os critérios criados por Ostrom e Mckean (2001) e adaptados para o presente estudo.

\subsection{Arranjos institucionais das comunidades}

De acordo com Ostrom $(1990,1999,2007)$, os atributos da comunidade vão influenciar a maneira como os atores reagem e interagem frente aos problemas enfrentados. Para que se compreenda a fundo como cada uma das comunidades está organizada, serão identificadas e analisadas as seguintes variáveis: contexto histórico, modo de organização, regras internas e participação dentro do conselho. 


\subsubsection{Comunidade do Marujá}

\subsubsection{Contexto histórico de ocupação na comunidade}

A comunidade do Marujá tem um histórico de ocupação no Parque Estadual da Ilha do Cardoso que antecede a própria criação do parque, em 1962. Ezequiel Oliveira, principal liderança da comunidade, relata que, por volta de 1853, seus tataravôs saíram do Vale do Itajaí e se estabeleceram na região de Cananéia, primeiramente na parte do continente e depois na Praia do Meio, onde hoje está a comunidade do Marujá.

A população tradicional vivia da agricultura, e, até meados de 1950, a pesca artesanal era praticada apenas por poucos moradores. A ausência de sistema de refrigeração impossibilitava a venda de pescado fresco, e a salga do peixe era a única alternativa para a sua comercialização naquela época. Marinho (2013) denomina essa época como "tempo das roças, mutirões e fandangos". Os roçados eram feitos por meio de mutirões, e o fandango era a prática de lazer ao final do dia de trabalho. Na década de 1960, a pesca passa a ter maior importância para os moradores locais, com a venda do peixe fresco levado diretamente para o Ariri ou para Cananéia, ou ainda armazenado em caixas de isopor com gelo vindo de Cananéia, já que não havia produção de gelo na ilha.

A partir de 1962, com o decreto de criação do parque, a agricultura passou a ser proibida no interior da unidade de conservação, e muitos moradores que viviam da agricultura acabaram migrando da ilha. Os que resistiram e permaneceram na ilha, nessa época, foram os que já desenvolviam atividades relacionadas à pesca. A agricultura, no entanto, continuou a ser praticada na região até meados de 1985, segundo relato de morador tradicional:

Esse pessoal que ficou que fez mais resistência, porque vivia mais da pesca. Mas nós continuamos fazendo a agricultura até 1985, 1990, nós ainda fazíamos. Depois o pessoal foi parando, aceitando a regra do parque. E daí na década de 1980 começou a visitação pública, começou o turismo, que entrou como uma receita suplementar, para suprir essa coisa de não poder plantar (Morador tradicional do Marujá, líder da comunidade, entrevista concedida em 2014). 
$\mathrm{Na}$ década de 1950, antes do decreto do parque, destacam-se ainda dois fatores importantes na história da comunidade. Em 1956 a família Lippe, não tradicional, começa a implantar um loteamento na Praia do Meio, onde hoje está a comunidade do Marujá, denominado Parque Balneário Marujá, conforme Figura 9.

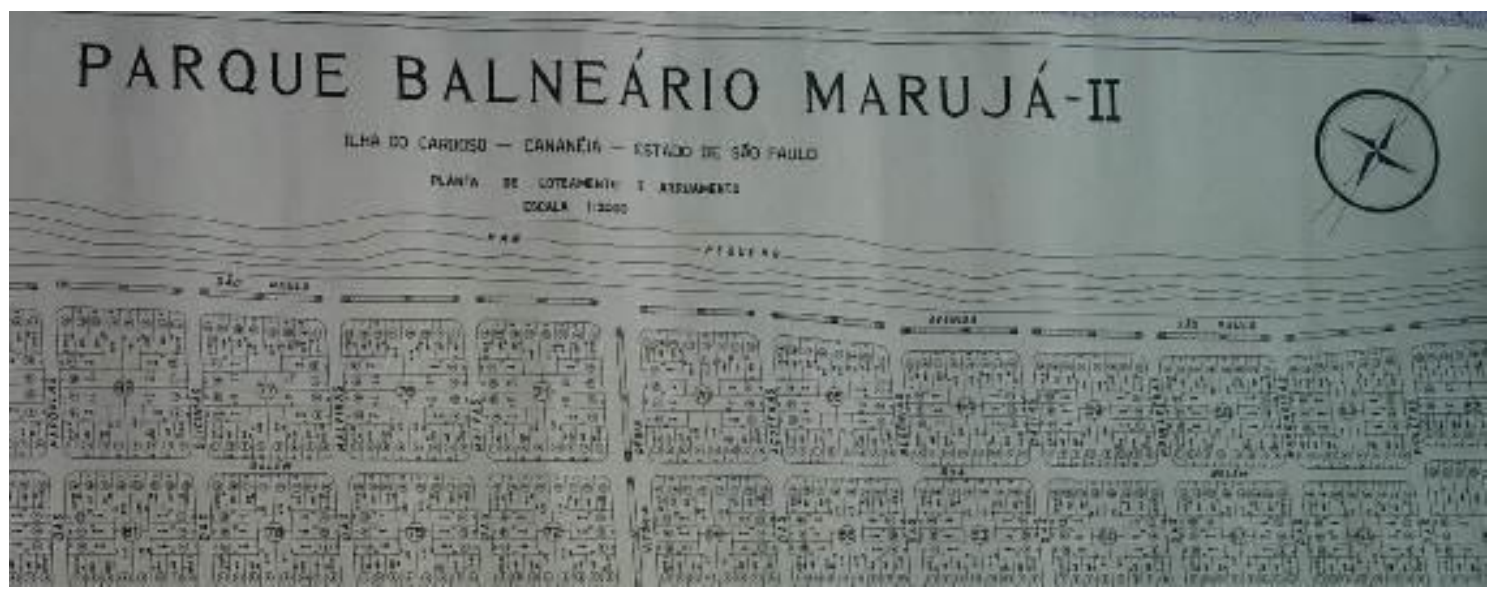

Figura 9 - Planta do Loteamento Parque Marujá - II

Fonte: AMOMAR, 2015.

Esse processo deu vazão à chegada de turistas de segunda residência na comunidade. À época da criação do parque, em 1962, apenas algumas pessoas já haviam construído casas no Marujá. Em 1970, houve uma nova tentativa de retomada do loteamento e de ampliação das áreas dos veranistas, por meio de um projeto de lei na Câmara Municipal de Cananéia que objetivava transformar o Marujá em zona de expansão urbana, felizmente indeferido (MARINHO, 2013). Nessa mesma época, ocorrem também tentativas de expropriação das comunidades por parte da Marinha, sob a alegação de que se tratava de um bem da União. Marinho (2013) comenta que esse processo de especulação imobiliária e de tentativa de expropriação dos moradores provavelmente intensificaria o processo de desterritorialização das comunidades tradicionais da Ilha do Cardoso, causando mudanças irreversíveis nos modos de vida locais, caso de fato se concretizasse.

Com o aumento do fluxo de turistas na comunidade, os moradores puderam obter uma renda além da atividade pesqueira, possibilitando sua permanência na ilha. Hoje, o turismo tem grande importância na renda familiar de boa parte dos moradores da comunidade. 


\section{Importância da formação de lideranças locais}

A influência da igreja católica foi de suma importância, tanto para a formação política de sua principal liderança, quanto para a própria organização da comunidade. Por volta de 1975, o padre João 30 era o vigário geral de Cananéia e atuou por mais de 20 anos em defesa dos direitos dos moradores da Ilha do Cardoso e das comunidades rurais do município.

Naquela época já havia uma preocupação com os problemas da comunidade, mas os moradores de maneira geral não queriam participar de reuniões para discutir estes problemas. Ezequiel Oliveira, liderança local, então percebeu que poderia utilizar os encontros comunitários da igreja para inserir essas preocupações. Durante os cultos, havia um momento reservado para discutir os problemas da comunidade e listar possíveis soluções.

Outro fator decisivo para a formação política da liderança foi sua capacitação como agente comunitário de saúde, em 1981. Por meio dessa capacitação, ele foi autorizado a utilizar alguns tipos de medicamentos alopáticos na comunidade, contribuindo para sanar muitos dos problemas de saúde na própria comunidade.

De acordo com Marinho (2013), Ezequiel foi um dos primeiros na comunidade a ter uma opinião formada sobre os possíveis impactos resultantes do crescimento desordenado do turismo, a partir de uma visita a comunidades caiçaras em Trindade e Picinguaba, onde pôde conhecer de perto os processos relacionados à especulação imobiliária, que impulsionaram a expulsão dos moradores tradicionais, transformando-os na maioria das vezes em trabalhadores subalternos.

A partir dessa consciência e da possibilidade de começar a discutir os problemas da comunidade coletivamente, Ezequiel acaba se tornando uma das principais lideranças da comunidade, tomando a frente em muitos processos posteriores que fariam do Marujá um modelo de referência quando se trata de gestão comunitária e processos participativos.

É preciso ressaltar, no entanto, como afirma Marinho (2013) e Rodrigues (2001), que também outras lideranças locais foram determinantes para a organização da comunidade. 


\section{Plano de Gestão Comunitária}

A partir da década de 1980, com o aumento do fluxo de turistas na comunidade do Marujá, os moradores começam a perceber os problemas e possíveis impactos advindos do crescimento desordenado do turismo. De acordo com Marinho, entre os principais problemas estavam a falta de saneamento e a ausência de controle dos visitantes, principalmente durante a alta temporada. A má distribuição de renda também já aparece como motivo de preocupação, já que nessa época apenas alguns moradores se beneficiavam economicamente da atividade turística (MARINHO, 2013).

De acordo com líder local, nessa época o turismo ainda era uma questão pouco explicada e difundida na comunidade. Os moradores começaram então a pesquisar sobre o assunto e a delinear quais os tipos de turista que visitam a comunidade e quais os benefícios e impactos negativos que cada segmento trazia,

E a organização do turismo também, quando o turismo entrou aqui a gente tentou estudar, refletir o que era esse turismo. Porque, na cabeça do caiçara, ele queria que o turista viesse; que ia deixar a grana e ponto final. E a gente descobriu, nessa discussão, cinco categorias de turista, que ia desde pescador esportista, o turismo de iate, que passa derrubando o barranco no rio, provocando erosão, esse iate ninguém deixa nada, a não ser o barranco derrubado e os filhotes de peixe e camarão triturado com a areia; o turismo de pesca esportiva, de pesca amadora, que traz muito pouco... pega um morador para catar a isca para ele, mostrar o pesqueiro e depois que mostra o pesqueiro não precisa mais dele. Então é outra categoria... uma terceira são os veranistas, que era o mais temido, pelo menos da minha parte, que era o cara que adquiria ou pressionava o morador para comprar a casa. Por último os campistas, bastante complicado para trabalhar, e por último o pessoal que alugava as dependências (Morador tradicional do Marujá, líder da comunidade, entrevista concedida em 2014).

Por meio de reuniões realizadas em formato de assembleias, os moradores do Marujá decidiram elaborar o Plano de Gestão Comunitária. O plano contemplava não apenas as diretrizes para a organização do turismo na comunidade, com a distribuição dos benefícios da atividade para todos os moradores, mas também outras diretrizes relacionadas à pesca, ao manejo florestal, à construção de moradias para novos moradores e ao limite de construção de novos alojamentos para receber turistas.

Marinho ressalta que esses acordos firmados pela comunidade no Plano de Gestão Comunitária tiveram fundamental importância para conter o processo de adensamento 
urbano e para minimizar os impactos ambientais, socioculturais e econômicos resultantes do crescimento desordenado que estava ocorrendo no Marujá.

(...) foi construído mediante longo processo de fortalecimento de lideranças locais e de aprendizagem social, contando com a cooperação e o respaldo de agentes individuais e de organizações externas (MARINHO, 2013, p. 99).

O Plano de Gestão Comunitária é fundamental para compreender os rumos que a comunidade do Marujá tomou até se tornar referência como modelo de gestão comunitária. A organização dos moradores partiu da própria comunidade, e não do envolvimento de atores externos, contribuindo não apenas para fortalecer esse processo de empoderamento, mas também para a construção da consciência política da comunidade.

\section{Plano de Gestão Ambiental do PEIC}

O Projeto de Preservação da Mata Atlântica - PPMA, pela SMA-SP (RODRIGUES, 2001), foi outro marco importante para a comunidade do Marujá. A elaboração do Plano de Gestão Ambiental envolveu não apenas a participação dos moradores, mas também a incorporação do Plano de Gestão Comunitária elaborado pela comunidade. Apresentouse como um marco para comunidade, na medida em que tinha como pressuposto a participação das comunidades em sua elaboração.

(Nós participamos do plano) todo, desde a discussão primária aqui, porque eram vários módulos... Um dia era pesquisa, outro dia fiscalização, outro dia o morador tradicional na unidade, e daí por diante. E a gente ficava aqui vendo o tempo todo a possibilidade, a necessidade de participar no que mais interessava (Morador tradicional do Marujá, líder da comunidade, entrevista concedida em 2014).

O Plano de Gestão Ambiental também serviu de base para a construção do Plano de Manejo aprovado em 2001. Nele consta, entre outras ações, a permanência das populações tradicionais, com regras que definiram quem era morador tradicional e teria direito à permanência na ilha, e quem não era tradicional e não poderia, portanto, ter residência na ilha. Continha também as diretrizes gerais para regular o turismo na comunidade, com limite da capacidade de quartos e áreas de camping, com base na socialização do recurso entre os moradores que já estavam inseridos na cadeia produtiva do turismo e também entre aqueles que tinham interesse em participar. Por 
fim, o plano também foi responsável pela formação do Comitê de Apoio à Gestão, que futuramente se tornaria o Conselho Gestor do Parque Estadual da Ilha do Cardoso.

\section{Criação da AMOMAR}

O ano de 1998 também marca a criação da Associação dos Moradores do Marujá (AMOMAR), com objetivo de oficializar o processo que já vinha ocorrendo na comunidade e organizar melhor as demandas e necessidades dos moradores.

De acordo com os moradores, a questão central quando se criou a associação era a organização do turismo. Antes disso, não havia qualquer tipo de regra ou limite para os turistas que visitavam a comunidade, a exemplo dos turistas que acampavam na praia e causavam problemas aos moradores.

A gente trabalha com turismo há 15 anos, que o turismo cresceu aqui; e aí veio o papel interessante da AMOMAR, de juntar a comunidade para organizar o turismo dentro da comunidade. Já que tinha um turismo desorganizado, muita baderna, vários baderneiros, áreas de camping na praia, o pessoal acampava na praia, em todas as partes da comunidade. Então foi uma das principais, um passo que a gente deu que foi fazer com que esse turismo viesse para dentro da comunidade (Morador tradicional do Marujá, presidente da AMOMAR, conselheiro no Conselho Gestor do PEIC, entrevista concedida em 2014).

No entanto, a questão inicial dos problemas com o turismo acabou fomentando as discussões para outras áreas problemáticas, a exemplo da questão da descaracterização da cultura caiçara, conforme explicita líder local:

Junto com a questão do turismo surgiu muito problema de cara, como a questão do consumo, da mudança de comportamento do caiçara, aquela coisa que eu tinha muito cuidado. $\mathrm{E}$ a gente começou a tentar organizar esse turismo do ponto de vista socioeconômico... Fazer com que a renda do turismo atingisse a comunidade o máximo possível, distribuísse renda dentro da comunidade. (Morador tradicional do Marujá, líder da comunidade, entrevista concedida em 2014).

Esse viés social de distribuição de renda e socialização dos benefícios da atividade turística direcionou a atuação da AMOMAR ao longo dos anos.

Em 1998, a comunidade foi beneficiada com uma verba de uma ONG alemã para organização de duas áreas de campings comunitários, com vistas a sanar os problemas advindos do excesso de gente acampando nos quintais das casas dos moradores. Nesse 
mesmo período, a comunidade começou a analisar a água do lençol freático e descobriu que havia excesso de coliformes fecais, o que provocava inúmeras doenças entre os moradores. Com o auxílio de diversos agentes externos, como pesquisadores e consultores, a verba da ONG foi então utilizada pela AMOMAR para implantar o sistema de abastecimento de água vindo da serra, que funciona até os dias de hoje.

A criação da AMOMAR foi fundamental para a organização dos moradores e para o fortalecimento da comunidade enquanto coletivo. A existência de uma instituição que organiza as demandas locais e dialoga com os demais atores contribuiu para garantir muitas das conquistas que a comunidade teve ao longo dos anos. Observa-se ainda que o Marujá foi a primeira comunidade na ilha a criar uma associação de moradores para centralizar as demandas locais.

\subsubsection{Modos de organização (cultura)}

A comunidade do Marujá hoje é considerada um dos modelos de referência quando se trata de gestão participativa e cogestão (MARINHO, 2013; PARADA, 2008). 0 histórico da comunidade, com a influência de agentes externos, como a igreja católica, a formação política de sua principal liderança, Sr. Ezequiel, e a elaboração do Plano de Gestão Ambiental foram fatores que contribuíram decisivamente nesse processo de organização comunitária. Entender como a comunidade se organiza hoje é fundamental para compreender os arranjos institucionais e os elementos que contribuem para que a comunidade seja tão ativa nesse processo emancipatório, mesmo não tendo conquistado a titularidade da terra, já que está inserida dentro de uma unidade de conservação de proteção integral, ou mesmo não tendo o reconhecimento formal e institucional por parte dos órgãos gestores desse modelo de gestão compartilhada.

\section{Desafios da comunidade}

Entre os principais desafios que a comunidade enfrenta nos dias de hoje, o saneamento e a ausência de energia elétrica são fatores de grande preocupação para os moradores. Não há ainda um sistema de saneamento que consiga abarcar toda a comunidade do 
Marujá. Atualmente a comunidade conta com fossa séptica, mas há anos tenta se organizar para conseguir verba para implantação de um sistema de saneamento local que seja mais efetivo. No entanto, o excesso de burocracia tem sido um entrave. Há um projeto em andamento elaborado pela comunidade para solicitar verba do FEHIDRO ${ }^{10}$. Para que a solicitação pudesse ser feita, a AMOMAR teve que conseguir um atestado junto à Secretaria da Fazenda do Estado de São Paulo, denominado Certificado Cadastral de Entidades, que a qualifica a solicitar esse tipo de ajuda financeira. Considerando não apenas a saúde dos próprios moradores e dos turistas que visitam a comunidade, devese considerar também o problema ambiental causado pela falta de tratamento do esgoto gerado pela comunidade e pela população flutuante. Principalmente durante o período da alta temporada, com o aumento do fluxo de turistas e visitantes na comunidade, o sistema de fossas não é suficiente para a demanda.

A falta de energia elétrica, de acordo com os moradores, também é um problema recorrente, principalmente para os que possuem comércio e restaurante. A principal fonte de energia atualmente são os geradores, que apresentam um custo relativamente alto, já que dependem de combustível para funcionar. Foi implantado na comunidade um sistema de energia solar, por meio do Programa Luz para Todos, do Governo Federal, na década de 2000. Quase todas as casas foram contempladas com o sistema. Foi possível observar, no entanto, uma certa falta de preparo para lidar com as especificidades técnicas, além de uma assistência precária por parte da empresa fornecedora dos materiais. A implantação do sistema contou com duas fases: na primeira, apenas algumas casas receberam um sistema que gerava pouca energia (aproximadamente $30 \mathrm{kww}$ ) e não atendia às necessidades locais; na segunda fase, um número maior de pessoas foi contemplado com um sistema que gera uma quantidade maior de energia (aproximadamente $80 \mathrm{kww}$ ).

É a luz, né? A falta da luz. Porque tem gerador, tem luz solar, mas não é como se tivesse luz elétrica. 0 pessoal está debatendo para ver se vem energia para cá. (...) Tem o sistema solar, mas quando chove não carrega as baterias e a gente fica na escuridão. Aí a gente gasta muito com óleo, com gasolina para o gerador. (...) É, tem luz solar, mas se tiver carregada acende, mas se não tiver e o gerador quebrar... Porque acontece do gerador quebrar, fazer manutenção. Aí se não tem gerador, fica difícil,

10 O FEHIDRO - Fundo Estadual de Recursos Hídricos, criado pela Lei 7.663/91 e regulamentado pelos Decretos 37.300/93 e 43.204/98, tem por objetivo dar suporte financeiro à Política Estadual de Recursos Hídricos e às ações correspondentes. Vinculado à Secretaria de Estado de Meio Ambiente. 
tem que comer à luz de velas (Moradora tradicional do Marujá, entrevista concedida em 2014).

Para além desses problemas do dia a dia, há moradores que afirmam que a maior dificuldade da comunidade hoje é o diálogo com o órgão gestor do parque, a Fundação Florestal. "Fazer andar as coisas" é a principal dificuldade nessa relação entre comunidade e parque. A revisão do Plano de Manejo é um dos projetos que está parado. De acordo com as normas ambientais, o plano aprovado em 2001 deve ser revisto a cada cinco anos ${ }^{11}$, e até hoje não houve qualquer modificação. Para Sr. Ezequiel, o poder discricionário do gestor é outro fator limitante. Segundo ele, o perfil do gestor influencia o modo como a gestão dialoga com as comunidades e também como são encaminhados os pedidos e demandas dos moradores:

Se o gestor tem uma visão mais ambiental, mais social também, ele trabalha o artigo 42 do SNUC, que diz que, até que se resolva, tem que cumprir a vida dos moradores com toda a dinâmica de uso do recurso natural. Se o gestor é preocupado com o social, ele se apega nisso aí, elabora ofício, relatório com esse cunho. Se o cara é mais sossegado, pega o artigo 62, que diz que tem que mandar embora, e não fala do outro artigo (Morador tradicional do Marujá, líder da comunidade, entrevista concedida em 2014).

Faz-se necessário ressaltar que, por estar inserida dentro dos limites de uma unidade de conservação de proteção integral, está sujeita às regras impostas pela Fundação Florestal e às normas que regem esse tipo de área de proteção. A comunidade não possui a titularidade da terra, o que faz com que os moradores precisem de autorizações da Fundação Florestal para qualquer modificação que venham a fazer em suas casas. As solicitações e pedidos de reforma ou construção são sempre assuntos polêmicos durante as reuniões do conselho gestor. No entanto, conforme afirmam os moradores, os desafios da comunidade, de maneira geral, são solucionados de maneira coletiva, sempre que possível.

\section{Formas de organização}

De acordo com Ezequiel, a comunidade sempre teve o hábito de fazer assembleias, mesmo antes da criação da associação dos moradores. A influência da Igreja Católica,

${ }^{11}$ Recomendação do IBAMA em Roteiro Metodológico para Elaboração de Planos de Manejo. 
como já mencionado anteriormente, foi fundamental na formação política das lideranças locais.

Nós tínhamos um hábito, por um longo tempo eu participei da igreja católica, e tinha dentro do culto, na católica progressista, um momento comunitário, para discutir problemas comunitários da comunidade. E nesse momento, a gente aproveitava, porque minha visão tendia mais para o social do que para o espiritual já, e a gente destrinchava todas as questões comunitárias dentro da igreja. E era legal. A gente começava a listar os problemas da comunidade e depois priorizava em número para ver qual a gente atacava primeiro, tentava solucionar e assim por diante (Morador tradicional do Marujá, líder da comunidade, entrevista concedida em 2014).

Com a criação da AMOMAR, as assembleias acabaram se tornando prática comum na comunidade e perduram até os dias de hoje. Todas as decisões são tomadas em assembleia. Em geral, os encontros ocorrem uma vez ao mês. Nos casos em que os assuntos são mais polêmicos, acontecem assembleias extraordinárias para que as decisões sejam postas em votação. Também é prática comum a formação de grupos de trabalho com temas que necessitem de pesquisas e maior aprofundamento nas discussões. A participação nestes grupos de trabalho é voluntária, e as decisões também são submetidas à votação nas assembleias.

Vale ressaltar que, por se tratar de um espaço aberto a toda comunidade, a participação não é obrigatória. Assim como em todo espaço coletivo, há pessoas que participam mais, outras que participam menos, e há ainda aqueles que nunca participam. Os fatores que influenciam a participação ou não dos moradores nas assembleias são inúmeros, indo desde a falta de interesse pelo assunto que está sendo discutido, até a falta de compartilhamento de ideal com as pessoas que estão à frente da associação. Há moradores que não concordam plenamente com as decisões, ou mesmo o modo de atuação dos membros da AMOMAR. No entanto, trata-se de um espaço democrático, onde todos têm direito a opinião. A própria gestão da AMOMAR é trocada a cada dois anos. É inegável, entretanto, que há moradores mais articulados e com maior poder de persuasão, que acabam se destacando na maioria das vezes.

Em muitos casos, destaca-se também o senso de pertencimento e de participação propriamente dito, que inclui a cidadania participativa e a própria formação política e ativista de alguns membros da comunidade. 
Tem umas que participam mais, outras menos interessadas, mas de certa forma todo mundo participa. Às vezes não vai à reunião, mas acaba conversando ou no bar, que é um lugar onde todo mundo conversa, tem aquele compromisso, tem aquele medo de estar na ata, então é aquele lugar que mais fala. E daí acaba dando opiniões que a gente leva para as reuniões. Então, de certa forma, todo mundo participa (Morador tradicional do Marujá, entrevista concedida em 2014).

A participação dos jovens ainda é incipiente na comunidade. Observa-se que há um predomínio da participação dos homens mais velhos. Os moradores relatam que o interesse e a abertura para a participação dos jovens é recente, tendo começado há poucos anos. É preciso ressaltar, no entanto, que a participação é quase inexistente no que se refere à questão de gênero. As mulheres, de maneira geral, não participam dos principais grupos de decisão, e algumas sequer participam das reuniões e assembleias.

Nesse contexto, é importante mencionar o importante papel dos espaços informais de participação, para além dos espaços formais já institucionalizados, a exemplo das assembleias da AMOMAR. Constituem-se de espaços de maior inclusão, que permitem que mesmo os mais tímidos ou menos afeitos à participação possam expressar sua opinião de alguma maneira. Em muitos casos, essas opiniões são repassadas por outras pessoas nos espaços já institucionalizados.

Os mutirões constituem-se ainda hoje de prática realizada na comunidade, ainda que em menor frequência. Trata-se de uma prática tradicional de comunidades caiçaras, que reflete o senso comunitário dos moradores em trabalhar para um bem comum. No Marujá, os mutirões mais comuns são os relacionados à limpeza de praia, à barragem da água que vem do morro e à limpeza dos caminhos. As ações, no entanto, são centralizadas pela AMOMAR, que acaba por organizar todo esse processo de ações coletivas.

A coleta de lixo também é organizada pela AMOMAR. Cada um dos moradores é responsável pela separação de lixo seco e lixo molhado. A AMOMAR se responsabiliza então pela coleta desse lixo e pelo transporte até o Ariri, comunidade no continente, onde o lixo é encaminhado aos caminhões da Prefeitura. 0 transporte até o Ariri é pago pela própria AMOMAR, e não pela gestão do parque. A Associação possui um fundo coletivo, cuja verba é arrecadada por meio de uma taxa que é paga por todos os moradores. 
Todos os anos, a comunidade realiza duas festas: a Festa da Tainha e a Festa de São Vito. Ambas organizadas pela AMOMAR, apresentam focos diferentes. A Festa de São Vito é uma festa em homenagem ao padroeiro da comunidade e comemorada pelos moradores. Trata-se de uma festa pequena, de cunho religioso, feita de maneira coletiva pelos próprios moradores. Já a Festa da Tainha é um evento maior, que atrai muitos turistas e moradores da região. A comunidade também participa, ainda que em menor escala, mas há um objetivo maior de gerar renda complementar durante o período de inverno, considerado baixa estação. Há algumas atividades promovidas pela AMOMAR, a exemplo de bingos comunitários, atividades para crianças e campeonato de futebol.

\section{Importância do turismo e a cogestão}

O turismo tem grande importância para a comunidade do Marujá, não apenas como atividade econômica que gera renda para os moradores, mas também por seu papel importante no fomento à organização dos moradores no que se refere à gestão do turismo na comunidade.

Como já mencionado, a organização da comunidade por meio do Plano de Gestão Comunitária e da criação da AMOMAR foi impulsionada pela tentativa da comunidade em organizar o turismo local. A atividade turística surge na comunidade como uma possibilidade concreta de os moradores obterem renda, principalmente após a proibição de execução das atividades extrativistas e de subsistência que praticavam na ilha.

Atualmente o turismo é uma das principais fontes de renda dos moradores locais, que gerenciam a atividade por meio dos empreendimentos turísticos, como as pequenas pousadas, campings e restaurantes. Boa parte dos moradores está de alguma maneira relacionado à atividade turística. A gestão do turismo na comunidade é feita, sobretudo, pela AMOMAR, responsável, inclusive, pela Operação Verão, que abrange o planejamento e execução de ações específicas para o ordenamento do turismo na comunidade, juntamente com a gestão do parque, durante o verão, quando a localidade recebe fluxos altos de turistas. A associação, que integra o Conselho Consultivo do parque, foi responsável por inúmeras ações de ordenamento da atividade turística junto ao órgão gestor, como o controle do fluxo turístico, por meio do estabelecimento do número máximo de barracas e quartos de pousadas permitido no Marujá. 
Ainda que a comunidade tenha seu poder de decisão cerceado pela Fundação Florestal, no que se refere à gestão do parque propriamente dita, há uma autonomia de controle e gestão da atividade turística por parte da comunidade, fruto de anos de acordos e conquistas por seus direitos.

\subsubsection{Regras internas}

A comunidade do Marujá tem nas regras, tanto as formais quanto as informais, sua principal base de apoio. Desde o Plano de Gestão Ambiental, a participação dos moradores na construção e elaboração das diretrizes e normas foi fundamental para garantir os direitos de permanência na ilha e o desenvolvimento de um caminho que levaria à gestão comunitária e a uma comunidade formada essencialmente por tradicionais.

O conjunto de regras que delimitam a atuação no parque vem do Plano de Manejo e das normas que orbitam as unidades de conservação de proteção integral, a exemplo do SNUC, na esfera federal, e dos decretos, leis e normas da SMA, no âmbito estadual.

Para além dessas regras formais provenientes do âmbito legal ambiental, a comunidade é regida por regras próprias, estabelecidas pelos moradores, principalmente na figura da AMOMAR. Trata-se de uma grande conquista da comunidade em anos de relacionamento com a gestão do parque, pelo direito de permanência do território e à sua autonomia. Ainda que a comunidade não tenha o poder de tomar sozinha boa parte das decisões - já que, por estar inserida no interior do Parque Estadual, precisa do respaldo da Fundação Florestal -, a AMOMAR é responsável por gerir os acordos já firmados e estabelecidos em anos de relacionamento com a gestão pública.

No que tange às regras formais, desde sua criação em 1998, a AMOMAR possui um Estatuto Social, que dita, em linhas gerais, o âmbito de atuação da associação e, mais detalhadamente, as regras burocráticas e administrativas que regem a associação. Entre essas regras mais relacionadas ao campo burocrático estão os direitos e deveres dos sócios, a administração dos poderes concedidos à Diretoria e ao Conselho, o Conselho Fiscal e outras questões relacionadas à prestação de contas e ao patrimônio da 
AMOMAR. Trata-se, portanto, de questões mais burocráticas, mas que são comuns no universo das associações que representam bairros ou comunidades.

De acordo com o Estatuto, são finalidades da AMOMAR:

I - promover, elaborar, incentivar, fomentar e avaliar projetos na área social, educacional, profissional, científica, tecnológica, cultural, esportiva, ambiental e de autossustentação e defesa das comunidades, grupos ou entidades congêneres;

II - atuar em defesa da regularização fundiária e das atividades econômicas, sociais e culturais de seus associados, bem como na valorização e fortalecimento dos conhecimentos tradicionais;

III - usar todos os meios legais necessários para conseguir melhores condições de vida para os associados, suas famílias e para os moradores do bairro do Marujá e vizinhança;

IV - assessorar entidades ou organismos financiadores, nacionais ou internacionais, de caráter público ou privado, na implementação, acompanhamento, avaliação e prestação de contas de projetos desenvolvidos pelos movimentos sociais e organizações da sociedade civil;

V - promover a mobilização, articulação e fortalecimento dos movimentos sociais e organizações da sociedade civil, por meio da disseminação e troca de informações;

VI - viabilizar e apoiar educação complementar gratuita, observando-se a forma de participação das organizações de que se trata esta Lei;

VII - viabilizar e apoiar programa de estágio para estudantes, atendidos os requisitos da Lei;

VIII - pleitear do Estado:

a) garantia de todos os direitos e a permanência dos moradores, previstos no plano de gestão do PEIC;

b) garantia de um espaço adequado para que as famílias dos moradores possam fazer suas culturas de subsistência, através de atividades autossustentadas;

c) a participação nas discussões sobre o plano de gestão compartilhada do parque e possíveis alterações;

IX - pleitear do município:

a) a implantação de estrutura básica mínima de escolas, serviços de saudade, água, luz, esgoto e coleta de lixo no bairro do Marujá; 
b) o direito de discutir a aplicação dos recursos que forem destinados pelo Estado ao município de Cananéia, a título de compensação financeira de grandes áreas de seu território, para fins de conservação;

X - propor aos Poderes Públicos a cooperação da AMOMAR para:

a) impedir a invasão de estranhos na ilha;

b) impedir que os moradores que vendam sua casa, abram nova posse;

c) cooperar pela responsabilidade na gestão, fiscalização, conservação e ocupação do Complexo Estuarino Lagunar;

d) fiscalizar os turistas e o turismo de modo geral, buscando impedir abusos contra os moradores, a sua cultura e contra o meio ambiente da Ilha do Cardoso;

e) impedir e denunciar todas as agressões à flora e à fauna da Ilha do Cardoso;

f) cobrar dos fiscais da Ilha do Cardoso o cumprimento de suas obrigações. (AMOMAR, ESTATUTO SOCIAL, 1999, atualizado em 2013)

Apesar de apresentar o escopo das possibilidades de atuação da AMOMAR, o Estatuto trata mais das regras administrativas da associação, e não exatamente das regras de convivência da comunidade.

Para tanto, a AMOMAR decidiu elaborar o seu Regimento Interno, que trata dos direitos e deveres dos moradores, assim como apresenta as normas e regras da comunidade. De acordo com o presidente da associação, a comunidade sempre contou com inúmeras regras internas, mas sempre de maneira informal.

E a gente conseguiu criar um regimento. A gente está fazendo um regimento interno que já existe; só que não tem nada escrito no papel. A gente está pondo isso no papel. Todas essas regras comunitárias estarão nesse regimento. Foi feita uma assembleia, dessa assembleia saiu uma câmara temática, um grupo para discutir, para pôr tudo isso no papel, chamar em assembleia e apresentar. Apresenta, assina todo mundo e a gente vai ter um regimento na mão que todo mundo vai ter que aceitar. 0 cara não participou porque não quis (Morador tradicional do Marujá, presidente da AMOMAR, conselheiro no Conselho Gestor do PEIC, entrevista concedida em 2014).

Como é de praxe na comunidade, foi definida uma Câmara Temática, formada por associados voluntários, que discutiu cada um dos itens que deveriam constar nesse regimento interno. 0 material produzido foi então apresentado em assembleia, no dia 28 de setembro de 2014, quando foi aprovado e o regimento entrou em vigor. 
A gestão do parque não participou da elaboração do regimento, mas é possível observar que entre as regras há diversas que se assemelham ou seguem as próprias instruções definidas e acordadas pela gestão do parque nas reuniões do conselho gestor. Constam no regimento, logo no início, as leis que regem as Unidades de Conservação, que, segundo o regimento, amparam legalmente todos os pontos dispostos no documento, a saber:

- Plano de Manejo do Parque Estadual da Ilha do Cardoso Fase 1 - Aprovado pelo CONSEMA. Regulamentado em 1998 e revisado em 2000;

- Plano de Manejo do Parque Estadual da Ilha do Cardoso Fase 2 - Aprovado pelo CONSEMA;

- Sistema Nacional de Unidades de Conservação (SNUC) - Criado em 2000 pela Lei Federal 9.985 de 18 de julho de 2000;

- Portaria Normativa FF no 138/2010 de 12 de julho de 2010.

A criação de parcerias com o Governo do Estado de São Paulo, a Fundação Florestal e a Prefeitura de Cananéia também está prevista no documento, com foco na permanência e na melhoria na qualidade de vida dos moradores tradicionais, a exemplo de projetos nas áreas de energia elétrica, saneamento, saúde, educação e questão fundiária. A AMOMAR afirma, no Regimento, o desejo pelos estudos relacionados à implementação de uma Reserva de Desenvolvimento Sustentável dentro do PEIC e ainda ressalta a importância do regimento para manutenção dos acordos firmados com a comunidade.

A AMOMAR apoia e incentiva os estudos e implantações nesta Unidade de Conservação, a mudança de categoria de Parque Estadual para Reserva de Desenvolvimento Sustentável (RDS). Este regimento é um instrumento de grande importância para continuidade de todos os acordos que já existem na comunidade do Marujá. Além disso, a AMOMAR pretende com este regimento buscar alternativas para que estes acordos continuem, sendo este considerado um documento oficial (AMOMAR, REGIMENTO INTERNO, 2014).

Entre os tópicos que constam no regimento interno estão os assuntos relacionados a construção, reformas e ampliações; limite de barracas e quartos para o turismo; taxas; lixo; utilização de gerador; representação no conselho consultivo; centro comunitário e de visitantes; operação verão; e animais domésticos.

O regimento interno do Marujá foi uma importante conquista não apenas da associação, mas dos moradores como um todo. Ao colocar no papel as regras e normas que antes só 
existiam no imaginário da comunidade, os moradores acabaram por institucionalizar esses acordos informais, permitindo um maior controle de como fiscalizar e mesmo cobrar tanto os moradores quanto a associação. E o fato de ter sido feito de maneira coletiva, com muita discussão e votado em assembleia torna o documento ainda mais rico no que se refere aos processos participativos locais.

\subsubsection{Participação dentro do conselho}

Como mencionado anteriormente, a AMOMAR foi criada no mesmo período da elaboração do Plano de Gestão Ambiental do PEIC e da formação do Comitê de Apoio ao PEIC. A AMOMAR participa das reuniões do conselho desde sua fundação, enquanto ainda era Comitê de Apoio, e não conselho gestor propriamente dito. O PEIC, assim como os moradores do Marujá, estava à frente de seu tempo quando se trata de participação em unidades de conservação. Nessa época, o SNUC ainda não havia sido criado, e a obrigatoriedade da criação de conselho gestor em parques do estado de São Paulo só veio a se concretizar em 2005.

De acordo com os conselheiros e moradores do Marujá, a participação no conselho é de suma importância não apenas como espaço para apresentar os problemas da comunidade, mas, sobretudo, para se posicionar e até "bater de frente" com o parque, quando necessário.

Porque é a única maneira que a gente tem de bater de frente com eles, a única maneira que você tem de concordar ou discordar com as coisas que aparecem. Você leva os problemas da comunidade para o conselho, acaba assimilando das outras comunidades que quase não participam (Morador tradicional do Marujá, presidente da AMOMAR, conselheiro no Conselho Gestor do PEIC, entrevista concedida em 2014).

Durante as reuniões do conselho, observou-se que a AMOMAR tem participação não apenas física, mas, sobretudo, efetiva nas decisões tomadas pelo conselho. Além do conselheiro, há sempre mais de um morador também presente nas reuniões. Ainda que não tenham voto, esses moradores conseguem expor suas opiniões e, sobretudo, acompanhar seus pedidos e solicitações, entregues ao conselho pelo conselheiro da comunidade. 
O conselheiro e o seu suplente, em geral, são escolhidos juntamente com a mudança de gestão da diretoria da AMOMAR, que ocorre a cada dois anos. Quando vence o mandato, a comunidade é convidada a participar da assembleia que irá escolher e votar os conselheiros para os próximos dois anos.

De acordo com o Regimento Interno da AMOMAR, é obrigação do conselheiro apresentar em assembleia as resoluções, decisões e informações discutidas durante as reuniões do conselho gestor. Em geral, as reuniões da AMOMAR ocorrem após as reuniões do conselho gestor do PEIC.

Para os conselheiros e moradores do Marujá, a existência do conselho gestor foi essencial para a maioria das conquistas da comunidade. Há um reconhecimento por parte dos moradores da importância do conselho e, sobretudo, da participação assídua da comunidade.

Conseguimos uma grande parte, acho que $80 \%, 90 \%$ das coisas que a gente conseguiu, aqui, sem dúvida, foi com ajuda do conselho. 0 conselho é essencial. Teve uma época em que andou meio capengando, a gente chamava ele de conselho anêmico. Mas aí parece que agora está criando um rumo de volta (Morador tradicional do Marujá, presidente da AMOMAR, conselheiro no Conselho Gestor do PEIC, entrevista concedida em 2014).

A participação do Marujá nas reuniões do conselho gestor foi fundamental para garantir muitas das conquistas obtidas pela comunidade ao longo dos anos. Os moradores e, em especial, suas lideranças, têm consciência da importância desse espaço para garantir alguma participação na gestão do parque ou mesmo para questionar e se posicionar frente às decisões tomadas pela gestão.

\subsubsection{Comunidade da Enseada da Baleia}

\subsubsection{Contexto histórico}

A comunidade da Enseada da Baleia possui mais de 100 anos de história na Ilha do Cardoso. Antonio Malaquias foi a grande liderança por décadas. Nascido na década de 
1940 no Parque Nacional do Superagui, vizinho à Ilha do Cardoso, no estado do Paraná, foi criado por pais adotivos, que o levaram para a Enseada da Baleia quando tinha 10 anos de idade. Aprendeu desde cedo as técnicas da salga do peixe com seu pai, que comercializava o produto de forma quase industrial. Quando Antonio Malaquias assume a produção do peixe salgado, no entanto, opta por fazer de maneira artesanal, trazendo mais benefícios para os trabalhadores.

Enquanto a agricultura era a base econômica de toda ilha, antes da criação do parque, a família do Malaquias vivia do peixe salgado, já que naquela época as condições de armazenamento do peixe fresco eram muito difíceis.

Com a criação do parque e as proibições de cultivo da terra, as demais comunidades começam a trabalhar com peixe fresco, vendendo boa parte de sua produção de pesca para a Enseada da Baleia. Malaquias era um empreendedor nato, como costuma lembrar os moradores locais. Apesar de ser uma das menores comunidades da ilha, ele movimentava um comércio considerável não apenas na comunidade, mas na ilha como um todo. Comprava o peixe fresco das outras comunidades e ainda possuía uma mercearia, sendo responsável pelo fornecimento de bebidas e produtos básicos locais.

Em 2010, Antonio Malaquias falece. A comunidade, basicamente formada por seus oito filhos, acaba ficando perdida, já que os negócios eram geridos principalmente por ele. Todo comércio e economia locais giravam em torno de sua figura.

Ele acordava todos os dias e mantinha aquilo, né? Só que as pessoas esperavam ele mandar fazer as coisas. Então ele coordenava. "Você faz aquilo, você faz aquilo". E aí quando ele faleceu as pessoas não souberam fazer a mesma coisa que ele. 0 peixe parou, a mercearia parou, o turismo anual que a gente tinha, pescadores passavam e compravam mantimentos, outros passavam no restaurante, parou tudo. E aí, com isso, as pessoas foram embora da comunidade. Nós perdemos quase $30 \%$ da comunidade com o impacto do falecimento dele (Moradora tradicional da Enseada da Baleia, presidente da AMEB, conselheira no CG, entrevista concedida em 2015).

A comunidade se viu numa verdadeira crise depois de seu falecimento. Com a interrupção de parte das atividades econômicas, algumas famílias deixaram a ilha em busca de condições melhores de sobrevivência. 
0 principal desafio da comunidade, naquele momento, foi exatamente resistir e buscar outras maneiras de sobrevivência que possibilitassem a permanência da comunidade na ilha.

Surge então a ideia de empreender produtos artesanais junto às mulheres da comunidade. A principal liderança atual da comunidade fomenta a organização das mulheres com vistas a gerar uma renda complementar, que pudesse ajudar as famílias a superar esse momento de crise.

Eu nem participava, nem representava a comunidade em nenhum lugar, nem no conselho do parque, eram outras pessoas. Eu trabalhava dentro da colônia de pescadores, trabalhei por sete anos lá. Me envolvi muito com a pesca e, num desses envolvimentos, fui fazer um intercâmbio pela Rede Cananeia, onde conheci um grupo de mulheres que trabalhavam artesanalmente. Aí eu voltei com ideia de imaginar, né? Porque o peixe seco eu nunca mexi, não tinha noção de como funcionava, então não dava para reviver aquilo que eu não entendia. E aí eu comecei a puxar com elas o que cada uma sabia fazer dentro da comunidade. E aí uma foi falando, eu pinto, eu bordo, eu faço crochê... Vamos tentar fazer alguma coisa com essas habilidades? Aí fizemos as ecobags, a gente se juntou e botou para vender na temporada, vendemos um monte, aí começou o grupo (Moradora tradicional da Enseada da Baleia, presidente da AMEB, conselheira no Conselho Gestor, entrevista concedida em 2015).

A empreitada foi um sucesso, e o grupo se formou, cresceu e se tornou o Grupo de Mulheres da Enseada da Baleia. Segundo a líder, desde o início, o objetivo do grupo era conseguir gerar renda para a comunidade e trazer de volta as pessoas que acabaram saindo da ilha por falta de perspectivas e de recursos. Com o apoio da Rede Cananéia, a comunidade conseguiu financiamentos de fontes diversas para executar pequenos projetos de empreendedorismo e economia solidária.

Em 2014, as mulheres decidiram também retomar a salga do peixe, conforme Figura 10, antes realizada apenas pelos homens liderados pelo Sr. Malaquias. Aprenderam as técnicas, conseguiram verba de projeto, para ter capital de investimento para a compra do peixe fresco, e começaram o processo de salga do peixe, que se mostrou também muito efetivo como renda complementar para a comunidade. 


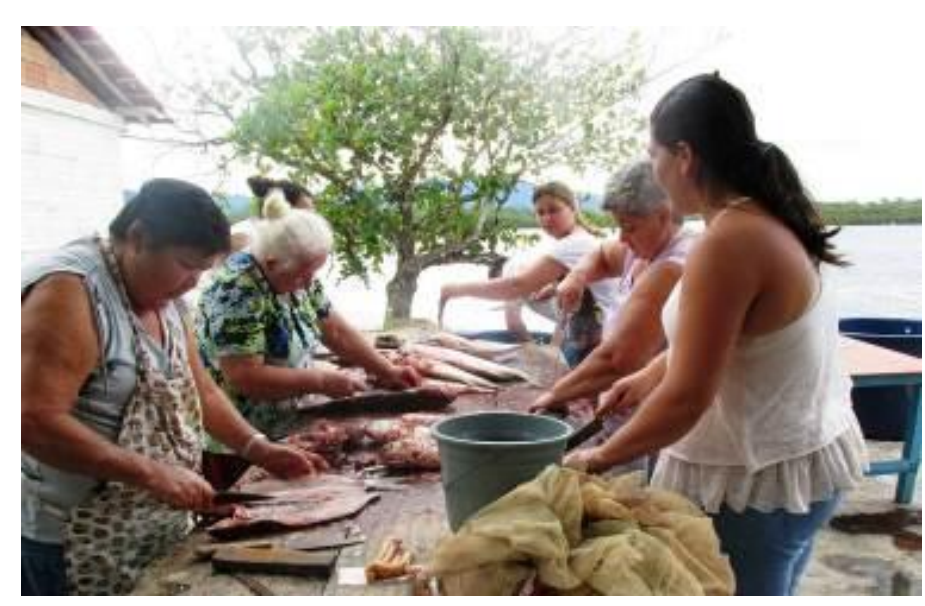

Figura 10 - Processo da salga do peixe pelas mulheres da Enseada da Baleia

Fonte: AMEB, 2015.

0 que se apresentou como um grande problema no momento (o falecimento de uma liderança e a falta de perspectiva dos moradores) serviu como oportunidade para a comunidade se organizar e desenvolver coletivamente outras formas de geração de renda e de trabalho, permitindo a permanência das famílias na comunidade e o empoderamento das mulheres que, como ocorre em geral nas comunidades caiçaras, possuem um papel mais secundário não apenas na geração de renda, mas nas decisões como um todo.

\section{Associação dos Moradores da Enseada da Baleia (AMEB)}

A Associação dos Moradores da Enseada da Baleia (AMEB) é bem recente, tendo surgido formalmente apenas em julho de 2014. Surge, a princípio, como uma demanda de formalização das comunidades para representação no conselho gestor. Sua criação, porém, vai muito além disso. A associação foi criada no bojo desse processo de mudança e transformação da comunidade, sendo a institucionalização da associação não apenas uma mera formalidade jurídica, mas também consequência desse fortalecimento comunitário.

(A Associação) é para gente se organizar dentro da comunidade, talvez mais a parte jurídica de representar a comunidade. Hoje ela vai servir para a gente conseguir se fortalecer. Tanto com projetos que ajudem a comunidade sem precisar passar pela mão de outras pessoas, que a gente mesmo consiga fazer para beneficiar a comunidade (Moradora 
tradicional da Enseada da Baleia, presidente da AMEB, conselheira no Conselho Gestor, entrevista concedida em 2015).

Os próprios moradores enxergam a associação como uma ferramenta jurídica de fortalecimento e de defesa dos interesses da comunidade, não apenas perante o conselho gestor do PEIC, mas também como maneira de empoderar os próprios moradores para que a comunidade possa caminhar com os próprios pés. Como é recente, a gestão ainda está em processo de formação, mas tem caráter descentralizador.

A comunidade vive atualmente esse processo de fortalecimento, não apenas da comunidade, mas das lideranças e dos próprios moradores, e isso se reflete em seu posicionamento enquanto comunidade tanto no conselho gestor, quanto perante a gestão do parque e até fora desse âmbito de unidade de conservação. Por meio de parcerias e projetos com instituições diversas, a comunidade vem ganhando mais autonomia na medida em que busca alternativas de renda e emprego para as famílias locais.

\subsubsection{Modos de organização (cultura)}

A comunidade hoje conta com 28 pessoas distribuídas em nove famílias. Os homens vivem da pesca, enquanto as mulheres cada vez conquistam mais espaço na renda familiar por meio das atividades do Grupo das Mulheres da Enseada da Baleia.

\section{Desafios da comunidade}

Um dos grandes desafios que a comunidade vive nos últimos 30 anos é o processo de erosão marinha acelerada que vem ocorrendo na região onde está inserida a Enseada da Baleia. Laudos do Instituto Geológico, bem como estudos de especialistas, identificaram um processo erosivo, fruto da dinâmica das correntes marinhas do canal sobre os barrancos da restinga nessa região, que ameaçariam todas as habitações da comunidade e tem como tendência a separação da ilha em duas partes. Segundo os estudos, com o avanço da erosão, ocorrerá o rompimento do esporão (trecho mais estreito da Ilha do Cardoso) e a consequente alteração da desembocadura do canal da Barra do Ararapira. 
Na década de 1980, o Sr. Malaquias, já preocupado com o avanço das marés, inicia um processo de contenção para assegurar algumas edificações que começaram a correr riscos de desabamento. Por meio de muito concreto, a comunidade foi tentando se adaptar ao avanço da maré.

Estudos realizados em 2010 estimavam que o canal iria se romper nesse mesmo ano, o que deixou a comunidade toda apavorada: “(...) em 2010 foi feita uma pesquisa de um estudante do Paraná, e eles analisaram que em 2010 iria furar. Então a comunidade ficou toda na expectativa, ficou, imagina, quando dá maré, eles ficam todos ansiosos" (Moradora tradicional da Enseada da Baleia, presidente da AMEB, conselheira no CG). No entanto, nada aconteceu em 2010.

Por conta de pedido da Promotoria do Meio Ambiente do Vale do Ribeira, o Instituto Geológico do Estado de São Paulo elaborou um laudo técnico a respeito do problema de erosão em 2011. A partir desse laudo, a Procuradoria Geral do Estado (PGE) emitiu um parecer no qual recomendava a saída de todos os moradores da comunidade.

No entanto, as estimativas de que o canal iria se romper, em 2011 ou 2012, também não se concretizaram. 0 processo de erosão, porém, continua existindo e é cada vez mais evidente, de acordo com os relatos de moradores e especialistas. É um assunto delicado que permeia o consciente e o inconsciente de toda a comunidade da Enseada da Baleia e que, ocasionalmente, é também tema das discussões das reuniões do conselho gestor.

Em 2015, um fato novo ocorre na comunidade. A Prefeitura de Ilha Comprida, município vizinho, começa a operar turisticamente um catamarã que passa justamente pelo Canal do Ararapira. A princípio, a rota do catamarã inclui sair da Ilha Comprida em direção à última comunidade da Ilha do Cardoso, o Pontal do Leste. Por se tratar de um barco com dimensões nunca antes vistas na região, desde o início de sua operação vem causando conflito entre os moradores do PEIC. No dia 9 de fevereiro de 2015, o catamarã tenta atracar na Enseada da Baleia, justamente na área de contenção construída pelo Sr. Malaquias. Com dificuldade para o atracamento, por se tratar de uma área revessa (correnteza que joga a embarcação para fora da área construída), o barco realizou diversas manobras. Em uma delas, o movimento de manobra foi tão forte que acabou derrubando quatro edificações: a casa de limpeza do peixe, a casa da Jacqueline, o restaurante da dona Erci e a casa da comunidade - vide Figura 11. A comunidade então 
acionou a gestão do parque e o Ministério Público Federal, de maneira a abrir um processo contra dos danos causados pelo Catamarã.

O processo todo de reunião de material e de discussão coletiva foi acompanhado durante as reuniões do conselho gestor, e serão mais bem delineadas nos capítulos posteriores.

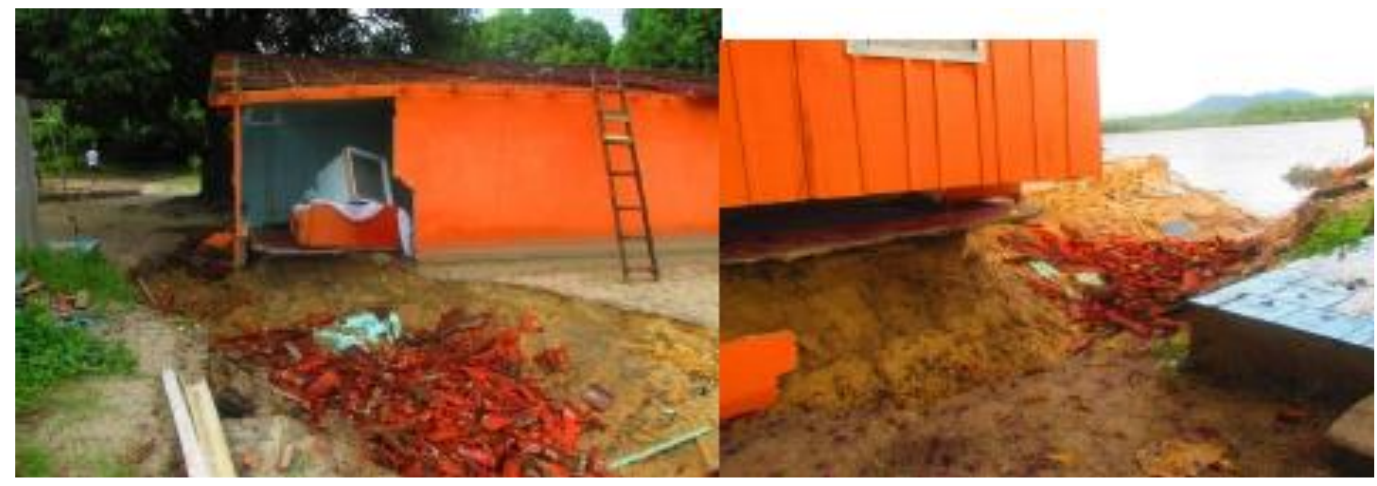

Figura 11 - Casas destruídas após acidente com embarcação na Enseada da Baleia.

Fonte: AMEB, 2015.

0 acidente reacendeu o debate sobre o processo de erosão na comunidade, apesar de especialistas terem atestado que o verdadeiro responsável pela queda das casas foi o catamarã, e não o processo erosivo propriamente dito.

De qualquer maneira, a erosão é um assunto bem polêmico para os moradores. De acordo com a AMEB, está em trâmite, junto ao Ministério Público, uma solicitação de realocação da comunidade para outra área do parque, nas proximidades do local onde está a comunidade hoje, mas que não corre o risco de ser tomada pela baía.

A gente escolheu uma outra área, que também está no Ministério Público, mas é uma área que tem o dobro da Enseada, de extensão, e que já foi da família há um tempo, e é uma área que já tem habitação, que já está desmatada. Só que lá tem uma casa de turista em cima que já está para ordem de demolição, e a gente solicitou junto ao MP que essa área fosse repassada para a comunidade, porque é perto, não mudaria a cultura, não mudaria o jeito de viver, e a gente estaria seguro. Então essa é nossa solicitação. E eles deram de prazo máximo 2 anos para a gente, para fazer essa análise. Para tentar analisar se nessa outra área vai acontecer erosão e tal (Moradora tradicional da Enseada da Baleia, presidente da AMEB, conselheira no Conselho Gestor, entrevista concedida em 2015).

Além da questão da erosão, alguns moradores comentam que um dos principais desafios continua sendo reestruturar a comunidade, após o falecimento do Sr. Malaquias. As 
mulheres tomaram a frente nessa reconstrução da comunidade, por meio de um processo de empoderamento e de fortalecimento do Grupo das Mulheres da Enseada da Baleia, mas trata-se de um processo lento, que demanda esforços constantes junto ao Grupo de Mulheres e junto ao restante da comunidade.

\title{
Turismo comunitário
}

O turismo na comunidade é incipiente ainda, sendo hoje apenas uma fonte complementar de renda.

O turismo de segunda residência sempre existiu na Enseada da Baleia, mas, diferentemente de como ocorria no Marujá e no Itacuruçá, era um turismo mais familiar. Havia uma relação de amizade e, inclusive, de ajuda entre a comunidade e os turistas, de acordo com os entrevistados, a exemplo turistas que prestavam atendimento médico ou que auxiliavam no transporte de lixo para Cananéia. Segundo os moradores, eram turistas que já possuíam uma consciência ambiental.

Dessa forma, quando houve a necessidade de retirada das casas de segunda residência, de acordo com o estabelecido em Plano de Manejo, o processo ocorreu de maneira tranquila. De acordo com os moradores, esses turistas que possuíam segunda residência na comunidade compreendiam que se tratava de uma área de preservação ambiental e, portanto, não entraram em desavenças com a comunidade ou mesmo com a gestão do PEIC.

\begin{abstract}
A Enseada da Baleia estava assim: comunidade tradicional lá mesmo. Sr. Malaquias, uma liderança local, e a questão do peixe. E metade das casas era de turista de veraneio. A relação lá na Enseada era muito mais saudável que o Marujá, porque lá não tinha o turista de veraneio que vinha abusar. Lá era o turista de veraneio que ia lá relaxar e interagir com a comunidade. Era um vínculo até maior de relação (Ex gestor do PEIC, de 1996 a 2007, entrevista concedida em 2015).
\end{abstract}

Os moradores relatam que, atualmente, os turistas que frequentam a comunidade, em sua maioria, são os filhos desses turistas que frequentavam a comunidade há décadas.

O turismo que é da Enseada é bem diferente das outras comunidades que você vai ver. As pessoas que vão lá hoje são as que a gente conheceu os pais delas. Então eu cresci junto com eles, eles trouxeram os amigos. Para o turismo a gente não gosta de muita bagunça, essas coisas todas, porque as pessoas trabalham e tal. Mas a gente não tem horário para 
fechar bar igual nas outras comunidades, a gente fica até a hora que der, o pessoal é tudo tranquilo. Não precisou criar nada de norma (Moradora tradicional da Enseada da Baleia, presidente da AMEB, conselheira no Conselho Gestor, entrevista concedida em 2015).

O fluxo de turistas na comunidade ocorre apenas durante o final do ano, entre o Natal e Ano Novo, e durante o Carnaval. No restante do ano, o fluxo é baixo, não sendo considerado uma fonte segura de renda em outros períodos.

Recentemente, têm surgido na comunidade algumas ações de fomento ao turismo de base comunitária, em especial fruto de parcerias com a Rede Cananéia. Os moradores se dizem empolgados com as possibilidades de desenvolvimento desse tipo de turismo, que pode trazer benefícios econômicos, em especial durante os períodos de baixa temporada. 0 foco do fomento ao turismo de base comunitária na comunidade, a princípio, são os estudos de meio realizados principalmente com escolas da região e de São Paulo.

\section{Formas de organização}

Com relação às formas de organização da comunidade, observa-se uma mudança perceptível após a morte do Sr. Malaquias. A coletividade e o poder comunitário se transformaram. Antes, havia a figura central da liderança do Sr. Malaquias, que fazia a gestão de toda a comunidade e era responsável por sua organização de forma geral. Não havia o costume de fazer reuniões, e as decisões não eram coletivas, mas centralizadas na figura da liderança.

Na época em que o Grupo de Mulheres foi formado, a líder conta que era muito difícil marcar reunião com as pessoas da comunidade, pois ninguém levava muito a sério. A transformação vinda com o empoderamento desse grupo feminino foi tal que hoje as reuniões acontecem pelo menos a cada duas semanas, e quase todos aparecem, pontualmente, inclusive os maridos.

No que se refere às questões relacionadas à produção, além do artesanato, as mulheres hoje também são responsáveis pela produção de mariscos e pela salga do peixe. A criação de mariscos surge dessa tentativa de geração de renda por meio de ações coletivas. Por meio de um projeto em parceria com a Rede Cananéia, foi possível atestar o nível de salubridade da água, confirmando a possibilidade de criação dos mariscos. 
Atualmente a comunidade consegue produzir para consumo próprio e para abastecer o fluxo de turistas na alta temporada.

0 peixe seco também é produzido de maneira coletiva pelas mulheres, por meio de gestão compartilhada. As atribuições de cada uma das mulheres são definidas de acordo com as habilidades individuais, e a renda é dividida igualmente entre todas as famílias. Os homens não atuam nesses processos de produção coletiva das mulheres. Por enquanto, eles mantêm apenas a atividade de pesca.

Então, os homens, eles pescam. No caso do peixe seco, eles também querem ajudar, mas a mulheres falaram que elas queriam só pedir ajuda para eles quando não dessem conta. Elas falaram: "não, a gente já está comprando peixe de vocês, então se a gente não aguentar, não der conta da produção, a gente chama vocês" (Moradora tradicional da Enseada da Baleia, presidente da AMEB, conselheira no Conselho Gestor, entrevista concedida em 2015).

As mulheres do grupo e, em especial, sua principal liderança, procuram participar em fóruns de discussão de economia solidária e feminista, além de organizarem intercâmbios com outras comunidades tradicionais para conhecer outras realidades e aprender com as histórias de luta de outras mulheres e coletivos.

Algumas tradições caiçaras ainda se mantêm na comunidade, a exemplo dos mutirões para construção de espaços coletivos e para limpeza da praia. Além disso, no mês de janeiro, a comunidade realiza a Festa de São Sebastião, em homenagem ao padroeiro. A festa é pequena, feita por toda a comunidade, e a renda obtida com a festa é guardada em uma espécie de fundo, utilizado quando há alguma demanda da comunidade ou dos moradores.

Observa-se que o Grupo das Mulheres acabou transformando a organização da comunidade e ainda fomentou uma série de outras transformações, principalmente relacionadas ao senso coletivo e às práticas comunitárias. Decisões coletivas, empoderamento feminino, diversificação da renda e autonomia para buscar alternativas foram algumas das consequências de todo esse processo de transformação pelo qual a comunidade vem passando nos últimos anos e que vem contribuindo para fortalecer tanto a gestão comunitária, quanto a própria comunidade enquanto comunidade tradicional na luta pelos seus direitos de permanência no território. 


\section{Parcerias}

As parcerias institucionais são de suma importância para a comunidade, sendo a Rede Cananéia a principal delas. A Rede Cananéia é uma espécie de coletivo criado há mais de 10 anos com o objetivo de fomentar o desenvolvimento local na região. É formada por organizações da sociedade civil de Cananéia, com forte atuação no PEIC, principalmente nas comunidades do Marujá e da Enseada da Baleia. O contato mais frequente com a Rede Cananéia possibilitou que a Enseada da Baleia se aproximasse também de outras comunidades e conhecesse mais de perto as inúmeras possibilidades de financiamento por meio de editais e projetos. E foi justamente por meio desses projetos que a comunidade conseguiu fomentar as atividades artesanais e as outras atividades econômicas, que hoje vêm contribuindo para garantir renda aos moradores.

As redes de economia solidária também são parceiras da comunidade, a exemplo da SOF - Sempreviva Organização Feminista -, organização não governamental que atua no tripé movimento social, transformação e feminismo, com foco no fortalecimento das mulheres como sujeito político. De acordo com a líder, há uma relação de ajuda mútua entre a organização e a comunidade.

Outro parceiro que contribui de maneira significativa com a comunidade é a Defensoria Pública de Registro, que vem prestando assessoria jurídica para a comunidade em diversos assuntos.

O apoio de instituições externas foi de suma importância, no contexto de reestruturação da comunidade, e tem contribuído para garantir que a comunidade se organize de maneira que possa continuar desenvolvendo projetos de maneira autônoma.

\subsubsection{Regras internas}

Por se tratar de uma comunidade pequena e familiar, os moradores afirmam que não há regras estabelecidas dentro da comunidade. Há acordos subentendidos de convivência, assim como em toda família, mas não há regras explícitas a respeito do que se pode ou não fazer. 
Não, regras a gente nunca colocou. 0 que a gente faz é respeitar o que o outro faz. Então, em época de turismo, se um faz doce, o outro faz salgado. E, para decidir as coisas, a gente tenta decidir junto. Tem um bar na comunidade, e outras pessoas que vendem bebida, então tal horário um não funciona mais. São alguns dos acordos que a gente fez. Tudo acordo [de boca], regra a gente não tem nenhuma (Moradora tradicional da Enseada da Baleia, presidente da AMEB, conselheira no Conselho Gestor, entrevista concedida em 2015).

Como mencionado anteriormente, as decisões são tomadas coletivamente. Como em qualquer outro grupo ou coletividade, os moradores afirmam que há divergências de opinião, ainda que se trate de uma comunidade homogênea e pequena. No entanto, um dos principais objetivos das reuniões é justamente dar voz a todas as pessoas, sempre tentando chegar ao consenso, priorizando o que for melhor para a comunidade de maneira geral.

A gente até acha bom isso que as pessoas coloquem. A gente até lutou... A maioria das pessoas pensava em "não", mas não falava. Então a gente tentou fazer de uma maneira que as pessoas dessem voz para pessoas. A gente começou a dar voz, aí as pessoas falam, umas vão "pitacando", e aí a gente decide, entra num consenso mesmo (Moradora tradicional da Enseada da Baleia, presidente da AMEB, conselheira no Conselho Gestor, entrevista concedida em 2015).

Com relação às normas de turismo, que acabam envolvendo agentes externos à comunidade, há algumas regras estabelecidas junto ao PEIC, a exemplo do limite de 280 turistas dormindo em barracas e quartos. Os moradores conseguem atender bem esse número de pessoas durante a alta temporada. É comum, no entanto, que apareçam mais pessoas de passagem, principalmente durante o verão.

Com relação à renda dos produtos comercializados pelo Grupo das Mulheres da Enseada da Baleia, os valores são distribuídos proporcionalmente ao número de horas trabalhadas. Cada mulher é responsável por uma parte do trabalho, seja bordar, costurar, planejar, entre outras funções, fomentando as habilidades individuais de cada uma das artesãs do grupo.

Como se trata de uma unidade de conservação, é preciso reforçar que a comunidade está sujeita às normas e leis que regem as unidades de conservação de proteção integral, bem como às normas impostas pela gestão do parque, em nome da Fundação Florestal. Na prática, no dia a dia da comunidade, as normas que mais influenciam a rotina diária 
estão relacionadas a construção, ampliação e reformas. 0 turismo, ainda que incipiente, é gerido pela comunidade.

A partir da instituição da AMEB, a comunidade passou a contar com um estatuto social da associação que, em linhas gerais, apresenta suas diretrizes de atuação. Entre seus objetivos, a AMEB foca sua atuação na defesa dos direitos da comunidade, buscando a permanência dos moradores e a melhoria nas condições de vida local.

Artigo 2․․ A AMEB tem por finalidades:

l- Promover, elaborar, incentivar, fomentar e avaliar projetos nas áreas social, artesanal, educacional, profissional, científica, tecnológica, cultural, esportiva, ambiental, de moradia e de autossustentação e defesa de comunidades, grupos ou entidades congêneres;

ll- Atuar em defesa da regulamentação fundiária e atividades econômicas, sociais e culturais de seus associados, bem como na valorização e fortalecimento dos conhecimentos tradicionais;

lll- Usar de todos os meios legais necessários para conseguir melhores condições de vida para os associados, suas famílias e para os moradores do Bairro Enseada da Baleia e vizinhanças;

IV- Assessorar entidades ou organismos financeiros, nacionais ou internacionais, de caráter público ou privado, na implementação, acompanhamento, avaliação e prestação de contas de projetos desenvolvidos pelos movimentos sociais e organizações da Sociedade civil;

V- Promover a mobilização, articulação e fortalecimento dos movimentos sociais e organizações da sociedade civil, por meio da disseminação e troca de informações;

Vl- Viabilizar e apoiar educação complementar gratuita, observando-se forma de participação das organizações de que se trata essa Lei;

Vll- Viabilizar e apoiar programa de estágio para estudantes, atendidos os requisitos da lei;

Vlll- Pleitear do Estado:

A garantia de todos os direitos previstos no plano de gestão do PEIC, e, notadamente, a permanência dos moradores em seu tradicional território.

A garantia de um espaço adequado para que as famílias dos moradores possam manter e desenvolver as suas culturas de subsistência, através de atividades autossustentáveis; 
A participação nas discussões sobre plano de gestão do PEIC com vistas a possíveis alterações no sentido de melhorar a condição de vida da Comunidade Local;

IX- Pleitear do Município:

A implantação de estrutura básica mínima de escolas, serviços de saúde, água, luz, esgoto e coleta de lixo do Bairro Enseada da Baleia;

O direito de discutir a aplicação dos recursos que forem destinados pelo Estado ao Município de Cananéia, a título de compensação financeira pela ocupação de grandes áreas de seu território, para fins de conservação;

X- Propor aos poderes Públicos a cooperação da AMEB, para:

Impedir a invasão de estranhos na Ilha;

Impedir que os moradores vendam suas casas ou abram nova posse;

Cooperar pela responsabilidade na gestão, fiscalização, conservação e ocupação do Complexo Lagunar;

Fiscalizar os turistas e o turismo de modo geral, buscado impedir abusos contra moradores, a sua cultura e contra o meio ambiente da ilha do Cardoso;

Impedir e denunciar todas as agressões à flora e à fauna da Ilha do Cardoso;

Cobrar dos fiscais da Ilha do Cardoso o cumprimento de suas obrigações (AMEB, ESTATUTO SOCIAL, 2014).

Ressalta-se ainda o manifesto de corresponsabilidade a que se propõe a AMEB, no sentido de cooperar com a gestão do PEIC, principalmente na manutenção e preservação do patrimônio natural da comunidade.

É possível observar que, por se tratar de uma comunidade pequena e familiar, a inexistência de regras formais não impede que haja organização e senso de coletividade entre os moradores. Impera, dessa maneira, a solidariedade e o fazer coletivo com foco no bem geral da comunidade como um todo, o que fica mais difícil em comunidades onde o número de moradores é maior e apresenta maior complexidade interna de suas atividades. 


\subsubsection{Participação dentro do conselho}

A comunidade da Enseada da Baleia é uma das que mais participam das reuniões do conselho gestor, desde a sua fundação em 1998.

Entre os principais motivos para participar, os conselheiros destacam a necessidade de saber o que se passa na gestão, até como maneira de poder cobrar e exigir seus direitos e ainda estar ciente de seus deveres. Destaca-se ainda a possibilidade de colaborar com a gestão e com as outras comunidades.

Além da gente estar próximo do que está acontecendo, eu acho bom
poder colaborar com as outras comunidades e com a gestão e colocar
nosso ponto de vista. Porque, às vezes, tem comunidade que reclama.
Conheço outras comunidades que vivem reclamando da situação, o
próprio "Luz para Todos", as pessoas não participavam e depois vinham
reclamando... Então, se você não participa, não tem como reivindicar os
direitos. Então tem que estar próximo para poder cobrar (Moradora
tradicional da Enseada da Baleia, e conselheira no Conselho Gestor,
entrevista concedida em 2015).

O papel do conselheiro, nesse contexto, é de suma importância. De acordo com moradora tradicional, o conselheiro deve sempre se colocar no lugar do outro, da outra comunidade, no momento de votar em determinadas situações. Além disso, como afirma outra moradora, deve também levar as decisões e tudo o que acontece nas reuniões para a comunidade, de maneira que a informação seja repassada para os moradores.

Na visão da líder local, o conselho gestor é importante para organizar, entender e monitorar tudo o que acontece no parque e nas comunidades que estão dentro dele. É uma possibilidade da própria gestão estar mais próxima das comunidades, facilitando o diálogo e o monitoramento. Apesar de ser consultivo, os moradores comentam que o conselho funciona bem da maneira como está, ainda que não tenha autonomia para deliberar, especialmente quando envolve construção, ampliação ou reforma. Reconhecem, no entanto, que se o conselho fosse deliberativo e a unidade de conservação fosse de uso sustentável, como é o caso das reservas de desenvolvimento sustentável, seria mais fácil para a própria comunidade ter mais controle, sem tanta intervenção da gestão estadual. 
Atualmente, os moradores da Enseada da Baleia possuem uma cadeira no conselho gestor do PEIC como AMEB, com representante e suplente, e também uma cadeira da Rede Cananéia. Em geral, sempre um deles participa das reuniões do conselho gestor.

No entanto, é preciso salientar que, apesar da participação assídua, foi possível observar, durante as reuniões e também pela leitura das atas, que seus representantes participam, mas são pouco ativos nas discussões. Costumam se expressar com mais veemência quando se trata de assuntos específicos da comunidade e ficam mais quietos em outros assuntos. É uma característica bem marcante de seus principais representantes, que acaba influenciando a própria dinâmica das reuniões do conselho, como será melhor delineado posteriormente.

\subsubsection{Comunidade do Itacuruçá/Pereirinha}

As comunidades do Itacuruçá e Pereirinha, situadas na porção norte da Ilha, são as mais próximas de Cananéia, distante cerca de 15 minutos de lancha rápida. A comunidade do Pereirinha está localizada no Núcleo Perequê do PEIC, que conta com a maior estrutura disponível no parque, apesar de estar atualmente fechada para visitação.

São seis casas de moradores, mas boa parte deles reside em Cananéia. Há ainda dois restaurantes administrados pelos moradores locais. Parte dos moradores atua como monitor ambiental e guia turistas e grupos pelas trilhas da região.

\subsubsection{Contexto histórico}

A comunidade do Itacuruçá/Pereirinha é uma das mais antigas da ilha. Antes da criação do parque, os moradores viviam principalmente da pesca e, com menor intensidade, da caça e da agricultura para subsistência.

No Itacuruçá os moradores vivem predominantemente da pesca realizada em embarcações grandes com motores de centro. Os pescadores possuem cercos. Um dos membros desta vila conserta 
canoas de madeiras. As crianças frequentam a escola existente no Núcleo Perequê. As casas são de madeiras integradas na paisagem (restinga). Todas possuem energia solar, inclusive a igreja. A água potável utilizada pelos moradores é a mesma que abastece o Núcleo Perequê (SÃO PAULO, 2001, p. 63).

O processo de criação do parque, em 1962, de acordo com os moradores, teve um impacto grande para a comunidade. Por estar mais próxima a Cananéia e por concentrar o Núcleo Perequê, a comunidade era considerada a porta de entrada da ilha.

Quando decretou parque, as pessoas começaram a limitar o parque. Por ser um parque estadual, eles não viam muito bem o morador. Por ser unidade de conservação, algumas pessoas foram saindo. Foi dificultando as coisas. Por exemplo, não se podia pescar nos rios, o morador no plano de manejo ainda pode ter o consumo de caça, mas não pode vender. Então tudo isso tinha que fazer pedido. Roça também não podia mais (Moradora tradicional do Itacuruçá, presidente da AMOIP, conselheira no Conselho Gestor do PEIC, entrevista concedida em 2015).

Os moradores relatam que muitos começaram a sair da ilha em direção a Cananéia e a outras regiões de São Paulo e Paraná, entre outros fatores, por conta das proibições gerais. Mais recentemente, outro fator importante para entender as dinâmicas locais é a escola. Por muito tempo funcionou na comunidade uma escola que ia até o quinto ano do ensino fundamental. Após isso, as crianças tinham que estudar em Cananéia. A escola, no entanto, foi fechada e não há opção de transporte para as crianças (ou barco-escola, como chamam os moradores), constituindo um dos principais desafios da comunidade, de acordo com os moradores.

Ainda que a criação do parque tenha causado inúmeros conflitos locais, em geral os moradores afirmam e reconhecem que o decreto foi importante para conter o avanço imobiliário e para garantir a preservação ambiental da região.

\section{Estruturas do Núcleo Perequê}

Apesar do decreto de criação do PEIC ter sido em 1962, apenas em 1972 o parque começa a ser efetivamente implantado, com a construção do CEPARNIC - Centro de Pesquisas Aplicadas em Recursos Naturais da Ilha do Cardoso, no Núcleo Perequê. Controlado inicialmente pela Secretaria de Agricultura e Abastecimento do Estado de São Paulo, foi transferido na década de 1990 para a administração da Secretaria de 
Estado do Meio Ambiente. Por muito tempo, o CEPARNIC abrigou também a gestão do parque.

Mendonça (2000) aponta que a implantação do CEPARNIC trouxe muitos impactos para essa região, por conta das obras de hidráulica e da construção de alojamento, casas de técnicos e laboratórios. O centro foi construído para ser um dos polos de desenvolvimento pesqueiro do Estado de São Paulo e também núcleo de pesquisas de biodiversidade. No entanto, como afirma Mendonça (2000), nunca atingiu seu objetivo.

\begin{abstract}
Construído para ser um dos polos do projeto de desenvolvimento pesqueiro do Estado de São Paulo e um núcleo de pesquisas de biodiversidade, o CEPARNIC não atingiu seu objetivo. Também, não incorporou as necessidades da pesca local da Ilha do Cardoso nem no município de Cananéia. Acreditava-se que este centro de pesquisas promoveria naturalmente a conservação ambiental do parque estadual, mas isso não ocorreu. Além disso, esta obra acabou causando um dos maiores impactos ambientais na área norte da Ilha do Cardoso com o aterro da planície costeira (MENDONÇA, 2000, p. 148).
\end{abstract}

Em 2009, novas obras começaram no local, por meio do Programa Ecoturismo na Mata Atlântica, fruto de um convênio da Secretaria de Estado do Meio Ambiente com o BID Banco Interamericano de Desenvolvimento. Foram investidos cerca de R\$ 8 milhões em uma obra de reestruturação do alojamento e de construção de uma passarela suspensa. No entanto, a empresa contratada para realizar o serviço não executou as obras com a devida qualidade. De acordo com reportagem do jornal $O$ Estado de São Paulo, as obras foram entregues de forma precária, com muitos problemas: "alojamentos com o telhado caído, placas solares enferrujadas, passarelas parcialmente interditadas por risco de desmoronamento e um museu vazio" (ESTADO DE S. PAULO, 2013).

Atualmente, as estruturas construídas no Núcleo Perequê estão fechadas, e não há mais opção de alojamento para as inúmeras escolas que visitam o parque, ou mesmo para os pesquisadores que atuam na ilha.

\title{
Associação dos Moradores do Itacuruçá e Pereirinha (AMOIP)
}

A Associação dos Moradores do Itacuruçá e Pereirinha (AMOIP) foi criada em 2010. De acordo com os moradores, seu principal objetivo era fortalecer a comunidade não apenas juridicamente, mas também por meio da organização dos moradores. 
(...) teve que fazer um pouco para fortalecer a comunidade, porque é tudo mais fácil se você pedir em nome de um coletivo do que pedir individualmente (Moradora tradicional do Itacuruçá, ex presidente da AMOIP e ex conselheira no CONSELHO GESTOR do PEIC, entrevista concedida em 2015).

Na visão dos moradores, a criação da associação foi de suma importância para organizar a comunidade e garantir a representatividade no conselho gestor do parque. Contribuiu também para reforçar o senso coletivo da comunidade.

\subsubsection{Modos de organização (cultura)}

As duas comunidades contam atualmente com seis famílias, sendo que são poucas as pessoas que realmente permanecem ininterruptamente na ilha. Em sua maioria, as famílias possuem também residência em Cananéia, ainda que a principal atividade econômica esteja vinculada à ilha, por meio da pesca, dos restaurantes e dos serviços de monitoria.

\section{Desafios da comunidade}

De acordo com os moradores, a ausência de escola na comunidade constitui uma das principais dificuldades atualmente. Diferentemente do que ocorre no Marujá, por exemplo, não há opções de transporte para as crianças poderem estudar em outras regiões. Esse assunto sempre vem à tona nas reuniões do conselho gestor e é utilizado por alguns moradores como justificativa para não residirem ininterruptamente na ilha, como indica o Plano de Manejo.

Então isso foi dificultando, e um dos maiores motivos de eles saírem de lá foi a questão da escola, porque começou a acabar. Estudava até a 4 a série e depois fazia o quê? Não tinha barco para vir para Cananéia. Daí acabou a escola, e teve que ir para a cidade. Foi indo, foi indo, e as pessoas começaram a ter filhos e deixaram seus filhos estudando. Agora a gente quer retornar (Moradora tradicional do Itacuruçá, presidente da AMOIP, conselheira no Conselho Gestor do PEIC, entrevista concedida em 2015).

Essa é uma característica bem marcante da comunidade do Itacuruçá e Pereirinha. Boa parte dos moradores possui residência também em Cananéia, seja com casa própria ou 
alugada, principalmente por conta dessa dificuldade com a questão da educação das crianças. No entanto, apesar de residirem em Cananéia, a maioria deles trabalha na ilha, seja em um dos dois restaurantes da comunidade, seja como monitor ambiental, barqueiro ou pescador.

Outro desafio apontado pelos moradores são as dificuldades quanto à questão da falta de autonomia, quando se trata do território e da posse da terra. Por se tratar de um parque, os moradores não possuem a titularidade da terra e precisam de autorização da Fundação Florestal, não apenas para construir novas edificações, mas também para fazer qualquer tipo de alteração, ampliação ou mesmo reforma nas construções.

A questão da escola é um dos principais, mas tem uma questão de querer fazer... Por exemplo, eu caso, tenho minha família e não posso construir minha casa. Isso, eu vou ser bem sincera, eu acho uma humilhação, eu acho muito humilhante eu casar, meu irmão casar, e ter que ficar cinco anos morando no quarto da mãe porque não pode construir uma casa. Então eu acho esse um desafio grande para nós, e que a gente tem muita paciência (Moradora tradicional do Itacuruçá, presidente da AMOIP, conselheira no Conselho Gestor do PEIC, entrevista concedida em 2015).

Os moradores mais velhos relatam as dificuldades, principalmente em relação aos filhos, que vão crescendo, formando família, tendo filhos, mas precisam continuar vivendo na casa dos pais, pois os órgãos gestores dificilmente autorizam a construção de novas casas. Essas dificuldades todas, há muito tempo, têm levado à evasão dos moradores locais, o que, na opinião dos entrevistados, contribui para enfraquecer a comunidade como um todo. Essa fragilidade da situação das comunidades tradicionais pode também ser percebida ou reconhecida como uma estratégia dos próprios órgãos gestores para enfraquecer de fato essas comunidades, contribuindo para que deixem a unidade de conservação, na impossibilidade de sobreviver sob as condições impostas pelos órgãos gestores.

\section{Turismo comunitário e educação ambiental}

O Núcleo Perequê é um dos que mais recebem visitantes durante o ano todo no PEIC. Como fica a apenas 15 minutos de lancha do porto de Cananéia, é um dos passeios preferidos de quem visita o município. É possível dividir os visitantes em dois grupos distintos: escolas e público de fim de semana. 
As visitas monitoradas de escolas acontecem na Ilha do Cardoso há muitos anos. 0 parque concentra uma grande biodiversidade, com espécies de fauna e flora que constituem o ambiente perfeito para visitas de campo. Durante o ano todo, o núcleo recebe grupos de escolas não apenas da região, mas do Estado de São Paulo como um todo. Esse segmento específico do turismo contribui para gerar renda para a comunidade, por meio dos serviços oferecidos de monitoria e alimentação, e ainda colabora com a educação ambiental e a conscientização dos visitantes.

O outro grupo contempla os excursionistas de final de semana, que vão passar o dia na ilha. São formados por grupos com características diversas, mas que possuem proximidade com o turismo de massa. Muitos acabam levando a própria comida, mas também consomem nos dois restaurantes disponíveis na comunidade, que são geridos pelos moradores locais. Nos últimos anos, o número de visitantes aumentou expressivamente, chegando a um pico de quatro mil pessoas durante o feriado do Carnaval de 2014, de acordo com dados fornecidos pelo gestor do parque. Esse número acabou alarmando não apenas a gestão do parque, mas os próprios moradores, já que não há estrutura adequada e suficiente para atender tal demanda. No segundo semestre de 2014, a comunidade, junto com a gestão do parque e o conselho gestor, elaborou o Plano de Uso Público do Itacuruçá e Pereirinha, com vistas a criar regras e normas de visitação, inclusive com limite máximo de visitantes por dia. Algumas ações do plano começaram a ser postas em prática no verão de 2015, ainda de maneira incipiente. Uma das primeiras regras postas em prática pela gestão do parque foi a obrigatoriedade de cadastramento das embarcações que atracam no Núcleo Perequê. Foram realizadas diversas conversas junto aos principais atores envolvidos, mas o número de embarcações cadastradas foi pequeno. Quando as restrições de atracação foram de fato postas em prática, em meados de dezembro e janeiro de 2015, houve diversos conflitos com barqueiros locais e lanchas de proprietários particulares que não estavam cadastradas. 0 saldo, no entanto, tem sido positivo, de acordo com o gestor.

Além de estar muito próxima à cidade, a comunidade ainda abriga um dos principais núcleos de visitação do parque, estando historicamente sempre sob a vigia dos órgãos gestores. Justamente por esses fatores, observa-se que a comunidade possui ainda menos autonomia no que se refere ao espaço propriamente dito, quando comparado com as outras comunidades. 


\subsubsection{Formas de organização}

A comunidade está organizada em torno da AMOIP, mas, por se tratar de uma comunidade formada basicamente por duas famílias, tudo acontece em torno do núcleo familiar.

Em geral, ocorrem reuniões para a tomada de decisão na comunidade principalmente quando há assuntos importantes ou emergenciais. No entanto, por se tratar de um ambiente familiar, muitas das decisões são tomadas durante os próprios encontros familiares, a exemplo dos finais de semana, quando quase todos retornam à ilha para atender os visitantes nos restaurantes ou nas trilhas.

Fazemos (reunião). Ali, por ser uma comunidade muito pequena, que é uma família só ali. É praticamente uma família só. E a gente faz, por exemplo, a questão da capela tinha que reunir todo mundo, o pessoal. Não precisa de todo mundo, mas pelo menos da diretoria. A gente foi lá, sentou, decidiu e já mandamos para todo mundo. A gente não faz uma reunião todo mês porque não tem demanda. E o legal é que a gente não marca... A gente acaba um ligando para o outro, se encontra e já conversa. Bem mais fácil (Moradora tradicional do Itacuruçá, presidente da AMOIP, conselheira no Conselho Gestor do PEIC, entrevista concedida em 2015).

A AMOIP é responsável pela organização da Festa de Santo André, que acontece todos os anos no mês de novembro, em comemoração ao santo padroeiro da comunidade. Cerca de dez anos atrás, a festa tinha o cunho essencialmente religioso e era realizada apenas entre os moradores, famílias e pessoas das comunidades vizinhas. Havia um almoço coletivo ofertado pela comunidade, sem qualquer custo para os convidados. Há alguns anos, começou a aumentar o número de visitantes que apareciam para a festa, e os arranjos de comida começaram a ser insuficientes. Foi então que a comunidade começou a promover a festa como um atrativo local e passou a comercializar as refeições, como maneira de arrecadar dinheiro para a associação. A parte religiosa passou a ser realizada no dia do santo, enquanto a festa é realizada sempre no final de semana, quando há possibilidade de atrair mais visitantes.

A parte coletiva de "fazer" a festa, no entanto, continua existindo, já que todos ajudam na organização, e o dinheiro arrecadado permanece no fundo da associação, para eventuais demandas que possam aparecer na comunidade. 
Os mutirões também são comuns na comunidade, não mais focados na agricultura e na lavoura, como nos tempos antigos, mas de acordo com as demandas locais. Moradora tradicional relata que era muito comum haver mutirões de roça e para construção de casa de morador quando ela era criança. Hoje em dia, há mutirões de limpeza das praias, de organização da festa e de demandas e emergências que surgem na comunidade, a exemplo da reforma do telhado da capela.

Observa-se que a comunidade se organiza principalmente em torno da família e, mais recentemente, da associação de moradores. Criada para garantir a representação da comunidade no conselho gestor do parque, a AMOIP acabou fortalecendo os moradores institucionalmente, mas também fez emergir novas lideranças que questionam com mais veemência as regras impostas pelos órgãos gestores. 0 fortalecimento institucional da AMOIP ainda está em processo.

\subsubsection{Regras internas}

Na comunidade não há regras ou normas de convivência impostas aos moradores. Como se trata de uma comunidade familiar, não há a necessidade de regras formais escritas. Há normas de convivência implícitas, assim como ocorre na Enseada da Baleia. Em geral, a comunidade é unida e homogênea. Mesmo quando não havia associação, os moradores se uniam em torno de demandas e causas específicas da comunidade ou mesmo dos moradores.

No entanto, por se tratar de uma unidade de conservação, deve seguir as regras e normas ambientais impostas pelos órgãos gestores. Dois fatores ainda agravam a imposição das normas ambientais no caso da comunidade do Itacuruçá/Pereirinha: a proximidade com Cananéia e o fato da região ter abrigado por muito tempo o CEPARNIC e a própria sede do PEIC.

A associação nunca falou assim "você não pode", não tem essa. Cada um sabe as regras que tem ali e tenta seguir da melhor maneira possível. E para nós, ali é um pouco complicado, porque a gente é a porta de entrada. Porque você está aqui em Cananéia, vai ali. Mesmo que a gente não quisesse seguir as regras, não teria como. Porque é a entrada de tudo... Foi um setor público, hoje ainda é um setor público, mas já não 
tem aquela frequência grande de funcionários. Mas uns anos atrás, quando eu tinha uns 15 anos (+-1999), tinha uma frequência grande. 18 funcionários trabalhavam ali. E aquilo ali era muito bem organizado, muito legal. E depois foram aposentando, e não abriu concurso, e hoje em dia está daquele jeito, infelizmente meio que abandonado (Moradora tradicional do Itacuruçá, presidente da AMOIP, conselheira no Conselho Gestor do PEIC, entrevista concedida em 2015).

Com relação à visitação, as regras para pernoite incluem um número limite de barracas, sendo permitidas seis barracas nas casas com dois banheiros e quatro barracas nas casas com apenas um banheiro. Esse limite de pernoites, no entanto, não é um problema, pois a demanda para dormir na comunidade é pequena, de acordo com os moradores.

Em 2014, foi elaborado pelo conselho gestor, em conjunto com a comunidade, um Plano de Uso Público do Itacuruçá e Pereirinha. O objetivo do plano era controlar o número de excursionistas que passavam o dia na praia do Itacuruçá aos finais de semana e feriados. Em reunião do conselho, foi definido o limite de 1.000 por dia. 0 plano foi posto em ação em dezembro de 2015.

O Estatuto Social, elaborado na criação da AMOIP, apresenta, em linhas gerais, as normas burocráticas e administrativas que legislam sobre entidades desse tipo. Não há regras ou normas de convivência no documento. Entre os objetivos da AMOIP que constam no estatuto estão:

Promover e contribuir para o desenvolvimento da vida comunitária dos moradores do Itacuruçá e Pereirinha;

Representar os moradores da comunidade em suas reivindicações junto aos poderes constituídos, garantindo a defesa de seus interesses e direitos;

Promover e contribuir para o desenvolvimento humano, cultural, social e econômico da comunidade;

Desenvolver trabalho social junto aos idosos, jovens e crianças, distribuindo aos mesmos benefícios alcançados junto aos Órgãos Municipais, Federais e à iniciativa Privada;

Melhorar a qualidade de vida da comunidade em geral, defendendo-a, organizando-a e proporcionando bem-estar para seus moradores. (AMOIP, ESTATUTO SOCIAL, 2010)

Trata-se de linhas bem gerais de atuação da associação, com foco na representação dos moradores e desenvolvimento local. 
Observa-se que a ausência de regras formais de convivência interna não impede que a comunidade seja organizada e unida na busca pelos direitos dos moradores.

\subsubsection{Participação dentro do conselho}

A comunidade do Itacuruçá/Pereirinha está entre as que mais participam das reuniões do conselho gestor desde a sua fundação. De acordo com os moradores, a importância de participar das reuniões está relacionada à necessidade da comunidade de se posicionar em relação a todos os assuntos discutidos e também de se manter informada de todas as decisões e informes. Representar a comunidade e repassar as informações aos moradores é de suma importância de acordo com os entrevistados. Dona Beth é uma das moradoras que participam das reuniões desde quando ainda era Comitê de Apoio à Gestão. Ela guarda em seu caderninho todas as anotações das reuniões que participou.

Para os moradores, o papel do conselheiro é de suma importância, na medida em que ele tem poder de voto. Conhecer as realidades locais e estar ciente de tudo o que está acontecendo, não apenas na própria comunidade, mas em todas as outras do parque, é pressuposto para o conselheiro, de acordo com moradora tradicional.

Mas é um papel disso mesmo, de você estar ali representando a sua
comunidade, e ajudar a resolver as coisas. Diferente de um gestor só
resolver, é muita coisa. Então todo mundo junto para tentar, cada um
leva para sua comunidade, e aí ele não precisa ficar... A importância de
ter o conselho é que você consegue administrar o parque no geral,
somente com os representantes (Moradora tradicional do Itacuruçá, ex
presidente da AMOIP e ex conselheira no Conselho Gestor do PEIC,
entrevista concedida em 2015). De maneira geral, os entrevistados afirmam que se sentem parte da gestão quando participam do conselho gestor, sendo uma maneira, inclusive, de ajudar os gestores nas inúmeras demandas que surgem no âmbito do parque. Há um senso de corresponsabilidade por parte dos moradores, o que se reflete na presença constante durante as reuniões do conselho gestor. 


\subsection{Conselho Gestor do PEIC}

\subsubsection{Surgimento do conselho gestor do PEIC}

O conselho gestor do Parque Estadual da Ilha do Cardoso foi o primeiro conselho de unidade de conservação a ser criado no Estado de São Paulo.

O Comitê de Apoio à Gestão da Ilha do Cardoso foi formado em 1998, no âmbito do PPMA $^{12}$, como um embrião do que viria a ser o conselho gestor posteriormente. A criação do comitê pretendia democratizar a gestão dos parques estaduais que estavam contemplados pelo PPMA. A princípio, concedeu-se ao comitê o poder consultivo, mas, conforme indica Rodrigues (2001), o comitê tinha na prática um caráter deliberativo, diferentemente do que ocorria nos comitês das outras oito UCs abrangidas pelo PPMA. De acordo com a autora, esse aspecto só foi possível no PEIC por conta do gestor do parque, Marcos Campolim, que, na época, assumiu a coordenação do Comitê e incorporou uma abordagem de fato participativa, ao possibilitar que as decisões fossem tomadas coletivamente entre os membros do Comitê.

Banco KFW com financiamento PPMA. A exigência já articulada era de fazer os Planos de Gestão Ambiental, que eram os pré-planos de manejo. E um "zumzumzum" de estabelecer gestão participativa, Comitês de Apoio à Gestão. A hora que eu cheguei, caí nesse espaço fértil, que eu já conhecia, conhecia os moradores, eu falei "é isso". Vamos cair na participação, fazer uma gestão diferenciada. No final de 1997, a gente já começou a estruturar o Comitê, e foi formalizado no início de 1998, fevereiro acho (Ex gestor do PEIC, de 1996 a 2007, entrevista concedida em 2015).

A abordagem participativa que influenciou a gestão do parque e as reuniões do Comitê de Apoio a Gestão só foi possível graças ao poder de discricionariedade desse gestor, que optou por tomar as decisões coletivamente e garantir que as comunidades tradicionais pudessem alcançar certos direitos em relação à sua permanência no parque, ao invés de tratá-los como meros problemas à gestão (RODRIGUES, 2001).

12 PPMA - Projeto de Preservação da Mata Atlântica (RODRIGUES, 2001), 
Durante sua gestão, as reuniões do Comitê eram itinerantes e aconteciam nas próprias comunidades tradicionais, o que facilitava a participação dos moradores e fazia com que eles mesmos se responsabilizassem pela logística de realização dos encontros. Se, por um lado, todas as comunidades tinham a chance de serem ouvidas, por outro lado, os demais membros do Comitê tinham envolvimento direto com as diferentes realidades das comunidades do parque.

Todas as comunidades estavam participando. Todas sem exceção, gente do Pontal, do Cambriú. Porque eu comecei a fazer itinerante. Era maravilhoso. Imagina a comunidade chegar na reunião do conselho na sua comunidade. Era muito legal. A gente fez essa coisa itinerante, que era uma preocupação com a participação. Não era o Marujá. Era a ilha toda. Ah, Pontal estava muito atrasado? Então tem que ir lá, tem que ir lá mostrar as caras, levar pedrada, mostrar para os caras que não é bem assim. A gente fazia reunião aqui, mas a gente passou alguns anos fazendo itinerante. Às vezes não dava para ir no Cambriu direto, foram as que menos tiveram por conta de mar, da logística, mas as outras sempre tinham. A gente tinha caixa, chegava lá, ajudava, fazia almoço comunitário, ia "quebrando o gelo"... (Ex gestor do PEIC, de 1996 a 2007, entrevista concedida em 2015).

Posto isso, é possível compreender alguns aspectos que fizeram com que o PEIC se tornasse uma referência no âmbito da gestão participativa em unidades de conservação. No entanto, desde a elaboração do Plano de Manejo, no final da década de 1990, muitas mudanças ocorreram, em especial no que diz respeito aos órgãos gestores do Estado.

\subsubsection{Normativas}

O Conselho Consultivo do PEIC foi criado pela Portaria do Instituto Florestal - IF no 06 de 15/07/1998, e atualizada pela Portaria IF de 30/12/2004. Trata-se de um órgão colegiado, de caráter consultivo, que tem como objetivo central "apoiar as ações de implantação e gestão da unidade de conservação, assegurando o processo de gestão participativa iniciado".

De acordo com o disposto no Regimento Interno do Conselho Gestor do PEIC, a participação das comunidades tradicionais tem papel importante na atuação do conselho enquanto órgão de apoio à gestão do parque. 
I - Garantir a continuidade da participação dos órgãos públicos e da sociedade civil organizada, formalizada ou não, no acompanhamento e execução das atividades previstas no Plano de Manejo do PEIC, no sentido de apoiar a implantação e consolidação dos Programas de Gestão da Unidade;

II - Garantir e compatibilizar os anseios das comunidades tradicionais que habitam o PEIC, de forma efetiva com os interesses da conservação ambiental, buscando o desenvolvimento sustentável;

III - Aprimorar a gestão do PEIC, pela valorização dos ecossistemas de Mata Atlântica e associados a cultura caiçara, garantindo a utilização da Unidade para fins educativos e recreativos, dentro do que determina a legislação ambiental vigente;

IV - Sensibilizar a população do município de Cananéia e da região do Complexo Estuarino Lagunar de Iguape-Cananéia e Paranaguá sobre a importância da melhoria de seus ambientes para a garantia da qualidade de vida;

V - Possibilitar a abertura de novas formas de participação das comunidades tradicionais, subsidiando a tomada de decisões na Gestão do PEIC;

VI - Possibilitar que a implantação do PEIC venha a contribuir para o desenvolvimento socioeconômico ambiental do município de Cananéia e região do Complexo Estuarino Lagunar de Iguape-Cananéia e Paranaguá (REGIMENTO INTERNO DO CONSELHO GESTOR DO PEIC, grifo da autora).

Observa-se que o regimento interno do conselho reflete o próprio histórico de criação do conselho, inclusive na tentativa de garantir a participação das comunidades no processo de gestão e acompanhamento do conselho. Ainda que seja consultivo, apresenta-se como uma das ferramentas de gestão de que dispõe o gestor, além de ser uma ferramenta fundamental de posicionamento das comunidades em relação à gestão.

\subsubsection{Participantes}

De acordo com as normas, o conselho gestor de uma unidade de conservação de proteção integral deverá ser paritariamente distribuído entre representantes dos segmentos públicos e da sociedade civil organizada. A formação atual do conselho do PEIC data de maio de 2014 e estará em vigor até maio de 2016. Conta com 14 
participantes, sendo sete conselheiros da sociedade civil organizada e sete de órgãos públicos.

O gestor representa a Fundação Florestal e preside o conselho gestor. Entre os órgãos públicos estão a Prefeitura, a Câmara e a Secretaria de Educação do município de Cananéia, o ICMBio, a Polícia Militar e o Instituto Oceanográfico/USP. Foi possível observar algumas ausências constantes, a exemplo do ICMBio, da Prefeitura de Cananéia, da Câmara e da Política Militar Ambiental. No que se refere à sociedade civil organizada, apenas três comunidades estão devidamente representadas no conselho, por meio de suas respectivas associações de moradores: Marujá, representado pela AMOMAR, a Enseada da Baleia, representada pela AMEB, e o Itacuruçá/Pereirinha, representado pela AMOIP. Ocupando as demais vagas, o conselho ainda conta com a Colônia de Pescadores, a Associação das Escunas de Cananéia - ASSESCA, a Associação dos Monitores Ambientais de Cananéia - AMOAMCA e a Rede Cananéia.

Até meados de 2011, de acordo com a leitura das atas das reuniões, o entendimento era de que as comunidades tradicionais do parque tinham direito a uma cadeira cativa no conselho, independentemente de sua organização institucional. A partir de 2011, a Fundação Florestal pressiona para que haja uma adequação do conselho consultivo ao decreto Estadual 49.672/2005, que institui os conselhos gestores de unidades de conservação no Estado de São Paulo, passando a ser obrigatório que as comunidades interessadas em ocupar uma cadeira no conselho gestor estejam legalmente organizadas em forma de associação comunitária. A partir de então, a Enseada da Baleia começa a se organizar para formar a Associação dos Moradores da Enseada da Baleia (AMEB). A AMOIP já havia se organizado em 2010, a AMOMAR em 1998 e o restante das comunidades não possui organização formal.

Ainda que haja apenas três cadeiras para as comunidades, observa-se que há moradores tradicionais ocupando outras cadeiras no conselho, em órgãos públicos e instituições diversas. Na Rede Cananéia, a representante atual também é moradora da Enseada da Baleia, enquanto na Colônia de Pescadores o representante é morador do Itacuruçá, e na ASSESCA o representante é um morador do Pontal do Leste. Ainda, as representantes da Secretaria de Educação e da Prefeitura de Cananéia são moradoras do Itacuruçá. 
Considerando conselheiros titulares e suplentes, há 12 moradores tradicionais e 13 não tradicionais. Se analisarmos apenas os que votam - já que há apenas um voto válido por representação titular -, temos 5 moradores tradicionais e 9 não tradicionais como representantes titulares. Observa-se que as comunidades como um todo estão representadas e possuem força de voto no conselho gestor, ainda que nem todas as comunidades estejam representadas. Essa representatividade tem grande importância na garantia pelos direitos dos moradores tradicionais.

Observa-se que a participação das comunidades nas reuniões do conselho gestor do PEIC sofreu algumas transformações desde a sua criação, em 1998. Nessa época, todas as comunidades do parque participavam das reuniões do conselho. 0 fato de ocorrerem nas próprias comunidades contribuía para a participação das comunidades, inclusive das mais afastadas. No entanto, é possível também que as comunidades participassem mais porque acreditavam que sua participação poderia fazer alguma diferença. Conselheiros relatam que alguns fatores como excesso de burocracia e pedidos negados fizeram com que algumas comunidades e representantes fossem se afastando paulatinamente das reuniões. Ressalta-se que as dificuldades de deslocamento também continuam sendo um entrave, mas não são a questão central da não participação, na visão de alguns conselheiros.

Quadro 4 - Composição do Conselho Gestor do PEIC - 2014/2016

\begin{tabular}{|c|c|}
\hline $\begin{array}{l}\text { Membros representantes de órgãos } \\
\text { governamentais }\end{array}$ & Membros da sociedade civil organizada \\
\hline $\begin{array}{l}\text { Fundação Florestal / SMA-SP } \\
\text { Gestor do PEIC - Presidente do Conselho Gestor }\end{array}$ & $\begin{array}{l}\text { AMEB - Associação dos Moradores da Enseada } \\
\text { da Baleia }\end{array}$ \\
\hline Polícia Militar Ambiental & $\begin{array}{l}\text { AMOIP - Associação dos Moradores do } \\
\text { Itacuruçá e Pereirinha }\end{array}$ \\
\hline Prefeitura Municipal de Cananéia & $\begin{array}{l}\text { AMOMAR - Associação dos Moradores do } \\
\text { Marujá }\end{array}$ \\
\hline Câmara Municipal de Cananéia & $\begin{array}{l}\text { AMOAMCA - Associação dos Monitores } \\
\text { Ambientais de Cananéia }\end{array}$ \\
\hline Secretaria de Educação do Estado de SP & Rede Cananéia \\
\hline $\begin{array}{l}\text { ICMBio }- \text { Instituto } \begin{array}{r}\text { Chico } \\
\text { Conservação da Biodiversidade }\end{array} \\
\text { Mendes de }\end{array}$ & ASSESCA - Associação das Escunas de Cananéia \\
\hline Instituto Oceanográfico - USP & $\begin{array}{l}\text { Colônia de Pescadores Z9 - Apolinário de } \\
\text { Araújo }\end{array}$ \\
\hline
\end{tabular}


A participação em fóruns de discussão requer confiança nos processos de gestão e de inclusão. Marques (2010) argumenta que a motivação para participar está relacionada, em grande parte, à satisfação e à confiança nas instituições, assim como a certeza de que a participação será de fato considerada.

Para ex-colaboradora da Rede Cananéia, ex-conselheira do conselho gestor do PEIC e participante assídua das reuniões e discussões, o que move as pessoas a participar é o que de fato as ajuda. "Ninguém vai a um lugar que não te dê nada de retorno". Para ela, no conselho gestor do PEIC há os que acompanham o processo porque acreditam na gestão do parque, há os que estão lá simplesmente porque foram nomeados pela comunidade, mesmo sem entender muito bem o que isso signifique, e há os que não fazem parte desse processo e, portanto, não participam das reuniões ou mesmo das discussões.

Entre as comunidades que mais participam estão o Marujá e a comunidade do Itacuruçá/Pereirinha. A Enseada da Baleia também apresenta uma participação forte, mas um pouco menos constante, se comparada às outras duas. Pontal do Leste, Cambriú e Foles são as que menos participam das reuniões.

Segundo alguns conselheiros, muitas pessoas estão lá simplesmente para acompanhar os pedidos e solicitações de reformas e construção. Desconsideram ou desconhecem, portanto, o importante papel que desempenham, ou poderiam desempenhar, na gestão do parque como um todo, que vai muito além desses pedidos.

Sobre isso, a entrevistada ressalta que falta inclusão e que o conselho poderia ser muito mais participativo se também fosse inclusivo, principalmente quando se trata dessas comunidades mais afastadas. Para líder da comunidade da Enseada da Baleia, a participação seria mais efetiva, do ponto de vista político, se as comunidades se unissem.

Talvez se as próprias comunidades se juntassem e fossem "olha gente, a gente consegue quando se junta, fazer força, a gente precisa estar junto para fazer as coisas..." Eu acho que uma coisa política, mesmo que tivesse que ser feita, teria mais resultado (Moradora tradicional da Enseada da Baleia, presidente da AMEB, conselheira no Conselho Gestor, entrevista concedida em 2015).

Entre os demais atores que integram o conselho, é consenso a necessidade de participação da Prefeitura de Cananéia. Como o parque está inserido nesse município, há 
diversas questões que são discutidas durante as reuniões, mas que demandam informações ou mesmo ações diretas da Prefeitura.

\subsection{Regras em uso no PEIC e no conselho}

No âmbito do modelo de análise do Institutional Analysis and Development (IAD), a identificação e compreensão das regras em uso nas arenas e situações de ação é fundamental para a análise de como indivíduos ou coletivos se comportam mediante problemas específicos (OSTROM, 1990, 1999, 2001, 2011).

Como já mencionado em capítulos anteriores, os instrumentos legais que embasam, de maneira geral, as regras de gestão do PEIC e de funcionamento do conselho gestor são o Plano de Manejo e o Regimento do Conselho Gestor.

O regimento do conselho tem seu foco nas regras de condução e de tomada de decisão do conselho, a exemplo do número de participantes, da escolha dos participantes, das trocas de conselheiros, do quórum mínimo para que as decisões sejam válidas, entre outros. São regras formais que devem ser obedecidas para garantir alguns critérios básicos que regem os conselhos gestores, a exemplo da paridade dos participantes.

No que se refere aos participantes, de acordo com o regimento, o conselho gestor do PEIC tem o poder de escolher, por exemplo, quais representantes são passíveis de se eleger ou não a uma vaga no conselho, ou mesmo de sugerir novos participantes ou instituições, sempre respeitando os critérios de paridade. Também possuem o poder de decisão a respeito de quais participantes podem ser substituídos, caso não estejam cumprindo as regras estabelecidas de participação mínima. Pelo regimento, duas faltas seguidas sem justificativa já são passíveis de perda de cargo, tanto do representante titular quanto do suplente, ficando a cargo da instituição sua substituição. Durante as reuniões, foi possível observar que há diversas instituições que estão sempre ausentes. Ao mesmo tempo, notou-se também o interesse de outras instituições em se eleger a uma vaga no conselho. 
O Plano de Manejo do PEIC, por outro lado, apresenta as regras formais relacionadas diretamente à utilização dos recursos naturais. O Plano de Manejo do PEIC foi aprovado pelo CONSEMA em 2001, mas não passou por nenhuma atualização desde então. Ainda que esteja desatualizado, é utilizado como base norteadora tanto para a gestão do parque quanto para as próprias comunidades. A rigor, o conselho não tem poder de mudar as regras já instituídas no Plano de Manejo, mas há abertura para discutir casos específicos, utilizando-se das regras contidas no plano ou abrindo-se a discussão para que os conselheiros possam expor suas opiniões e chegar a um consenso.

Considerando-se as três comunidades analisadas, observa-se que todas, de maneira geral, respeitam as normas formais do parque e do conselho. Além de respeitar, nota-se que as comunidades acreditam na gestão e têm nas regras, formais e informais, uma base de apoio e confiança. É como se as regras atuassem como uma espécie de garantia para as comunidades, de permanência no parque e de proteção contra agentes externos, a exemplo da especulação imobiliária. Há muitas críticas à gestão, mas, de maneira geral, há uma compreensão de que as regras são necessárias. Observa-se um equilíbrio de forças entre Estado e comunidades (considerando apenas as três analisadas), no sentido de haver de fato uma gestão compartilhada, ainda que não formalizada e não institucionalizada pelos órgãos gestores.

Convém ressaltar que há outras comunidades menores no parque que não possuem essa proximidade com a gestão ou mesmo com o conselho gestor. Para algumas delas, essas regras não são tão importantes e não há essa confiança na gestão, como ocorre com as comunidades analisadas. De alguma maneira, os laços com a gestão foram perdidos ao longo do tempo. Essas comunidades estão fora da arena e não participam dos processos de decisão, ao menos não no âmbito do conselho gestor. Para esses indivíduos, as regras legais do PEIC e do conselho não são regras em uso e, portanto, como argumenta Ostrom (2007), há uma tendência de não respeito e de não cumprimento das normas por parte desses indivíduos. ${ }^{13}$

A partir das reuniões do conselho gestor e das entrevistas, observa-se que há uma percepção geral de que as regras contidas no Plano de Manejo e também as demais

13 Não foram entrevistadas as demais comunidades do parque. Trata-se apenas da percepção a partir das entrevistas e da observação durante as reuniões do conselho gestor. 
regras formais e informais, que são utilizadas até hoje, estão em grande parte embasadas no modelo de gestão e de vida da comunidade do Marujá e que não se adequam por completo à realidade das outras comunidades atualmente. É uma demanda constante das comunidades durante as reuniões do conselho, que argumentam que as regras em uso hoje não se adaptam às diferentes realidades locais, e que seria preciso que cada comunidade tivesse um conjunto de regras próprio de acordo com seus próprios arranjos e realidades locais. Essa questão reflete os diferentes arranjos institucionais de cada uma das comunidades, com modelos, regras e normas próprias de vida e de organização. De acordo com o atual gestor do PEIC, essa demanda das comunidades poderá ser atendida a partir da elaboração do Termo de Compromisso com as comunidades e famílias que residem no parque. Com base na portaria normativa FF/DE №138/201014, a gestão vem tentando abrir para discussão no conselho gestor a regulamentação de mecanismos que possibilitariam a permanência das comunidades tradicionais no interior das UCs. É um processo ainda bem recente no âmbito das políticas públicas relacionadas às unidades de conservação e que ainda poucas UCs estão tentando implementar.

O excesso de regras criadas pela gestão do parque e pelo conselho, desde sua fundação, foi um grande ganho no contexto da participação. No entanto, pode ser um problema, se considerarmos que há realidades diferentes que devem ser consideradas na gestão do parque e que injustiças podem ser cometidas ao se seguir as regras ao "pé da letra" sem considerar as diferenças e os contextos sociais. A entrevistada reforça que lidar com as injustiças sociais que são consequência desse excesso de regras é um grande desafio do conselho.

(...) a gente está numa fase em que criou muitas regras. Dosar as injustiças sociais que são cometidas, porque a gente não consegue dosar as regras, às vezes é que talvez seja o maior desafio também. Por exemplo, equiparar o Marujá a todas as outras comunidades como se tudo funcionasse na mesma frequência (Ex conselheira no Conselho Gestor do PEIC e participante assídua das reuniões do conselho, entrevista concedida em 2014).

14 Portaria Normativa FF/DE № 138/2010 - Estabelece os critérios e procedimentos técnicos e administrativos que deverão ser observados na análise das solicitações de autorizações para reformas, construções e instalação de energia elétrica necessárias à subsistência de pequenos produtores rurais e populações tradicionais ocupantes de áreas inseridas em unidade de conservação de proteção integral. 
Por outro lado, a entrevistada reforça que, apesar da gestão e do conselho contar com inúmeros problemas, trata-se de um espaço aberto onde é possível discutir os problemas da área rural, que dificilmente são discutidos em outros fóruns e instâncias participativas na região.

Além dessa dificuldade de lidar com as inúmeras regras internas no conselho do PEIC, outro ponto levantado pelos entrevistados é a ausência ou quase inexistência de regras para lidar com fatores externos que possam ameaçar ou causar algum tipo de dano ou problema às áreas protegidas do parque e às próprias comunidades.

Então eu acho que a gente tem hábito de legislar sobre pequenas coisas e não olha para as grandes. Não olha, não entende, não discute. E aí fica por isso mesmo. A restrição no uso de recursos naturais, ou mesmo esse tipo de deliberação, de mudar o banheiro de lugar... A gente fica muito tempo conversando sobre essas coisas, e eu acho que está na hora de olhar esse processo e ver qual foi o saldo positivo e qual foi o negativo. Vamos olhar para ele. E nisso também cabe um pouco de desapego por parte dos fundadores da instituição, os fundadores das regras, de olhar para o lado humano mesmo. Acho que esse excesso de ordenamento deixa de lado... O lado humano é deixado de lado constantemente (Ex conselheira no Conselho Gestor do PEIC e participante assídua das reuniões do conselho, entrevista concedida em 2015).

Entre essas questões externas estão, por exemplo, outras áreas de conservação sobrepostas ao PEIC, a poluição da baía, a falta de fiscalização da indústria pesqueira, a ausência de regulação para a atracação de barcos de médio e grande porte, entre outras inúmeras questões que vêm ocorrendo na região e que podem afetar negativamente as áreas do parque.

Durante as reuniões do conselho, ainda foi possível observar que, embora os conselheiros tenham na regra o fio condutor das reuniões, muitas das decisões tomadas e votadas em conselho não necessariamente possuem o aporte das regras formais de gestão do parque. Como o plano de manejo está desatualizado, muitas das regras contidas nele não se adequam mais às realidades atuais. Há ainda questões que o plano não contempla, mas que precisam ser decididas e votadas pelos conselheiros, ou necessitam de uma posição formal dos mesmos. Para cada um desses casos, não há uma regra formal, mas pequenos acordos formais ou informais que são retomados, ou mesmo novas informações são trazidas à tona para a tomada de decisão e, assim, novas regras são formadas. 
Durantes as reuniões do conselho, foi possível acompanhar alguns desses processos de decisão, como, por exemplo, o caso da filha de uma moradora tradicional que fez a solicitação de uma casa no mesmo terreno onde a mãe mora. Como a maioria dos conselheiros não conheciam as pessoas envolvidas e seu histórico, a moradora e sua filha foram chamadas para apresentar a situação perante o conselho gestor. A polêmica surgiu, pois a solicitante não residia na ilha há muito tempo, o que, pelo disposto no Plano de Manejo, a impedia de retornar como moradora tradicional e, portanto, solicitar a construção de uma nova casa. Durante a reunião foram levantadas algumas especificidades do caso: a mãe da solicitante vive sozinha na ilha desde a morte do marido e, por se tratar de um sítio isolado, não há vizinhos; a construção da casa não demandaria supressão de mata, pois há espaço no quintal da moradora; a solicitante é professora em escola do Ariri, zona rural que fica perto da ilha, o que facilitaria o seu deslocamento diário; a solicitante alega que, apesar de não residir de fato na ilha há muito tempo, está frequentemente na casa de sua mãe, que necessita de cuidados especiais por conta de sua idade; há uma solicitação de construção de casa aprovada pela Fundação Florestal no mesmo local para a irmã da solicitante, mas a mesma não pretende construir a casa. Os conselheiros ficaram cerca de duas horas discutindo o caso. Houve os que defenderam a aprovação da construção pelo conselho, alegando que se tratava de um caso específico, que não traria prejuízos e ainda contribuiria para fortalecer a zona rural da ilha; mas também houve os que se mostraram contra, alegando que tal aprovação poderia abrir precedentes para muitas outras pessoas que deixaram a ilha há muito tempo solicitarem novas construções. Por fim, foi decidido por meio de voto da maioria a aprovação da solicitação, que seguiu para a Fundação Florestal, que tem a decisão final sobre novas construções na ilha. Percebe-se que as regras contidas no Plano de Manejo não se adequavam ao problema imposto pela solicitação da antiga moradora, o que obrigou o conselho a deliberar coletivamente qual seria a melhor solução para o caso.

Esse foi apenas um dos casos observados durante as reuniões acompanhadas, mas houve diversos outros que comprovam a flexibilidade do gestor e dos conselheiros para se adaptar às demandas dos diversos problemas que surgem durante as reuniões. Essas regras não instituídas pelo Plano de Manejo ou pelas normas ambientais são de suma importância no contexto da participação das comunidades, pois possibilitam uma 
flexibilidade que permite o envolvimento e a participação dos atores nas decisões no âmbito do conselho gestor.

\subsection{Como funciona o conselho - Interações e decisões}

A partir da compreensão das regras em uso pelo conselho, é possível entender como se dão os processos e interações dentro da situação ação, bem como os papéis que desempenham os diferentes atores do conselho, mantendo o foco, sempre que possível e se fizer necessário, na atuação das três comunidades analisadas: Marujá, Itacuruçá/Pereirinha e Enseada da Baleia. Busca-se neste capítulo, portanto, tecer análises a respeito das interações, decisões e posturas dos atores frente às regras formais e informais.

\subsubsection{Definição das reuniões}

As reuniões do conselho gestor ocorrem mensalmente, na primeira terça-feira do mês. A escolha da data foi definida pelos próprios conselheiros. Para as comunidades que vêm da ilha, coincide com o dia de feira em Cananéia, e muitos aproveitam a viagem para comprar produtos e mercadorias para levar para a ilha.

Atualmente as reuniões ocorrem na sede administrativa do parque, localizada em Cananéia (vide Figura 12). Alguns dizem que o fato de ser em Cananéia dificulta a participação, principalmente das comunidades localizadas em áreas de difícil acesso ou mais distantes de Cananéia, a exemplo do Pontal do Leste, de Cambriú e Foles. Além das dificuldades com as marés, como é o caso de Cambriú e Foles, há também a questão econômica. Não há ajuda por parte da gestão do parque para as comunidades, e os gastos com combustível para a viagem até Cananéia são altos, em especial para as comunidades com menos recursos econômicos. Por outro lado, de acordo alguns entrevistados, há falta de interesse por parte de algumas comunidades em participar das 
reuniões do conselho, pois a gestão atual é aberta para conversa e para eventuais pagamentos de despesas com combustível.

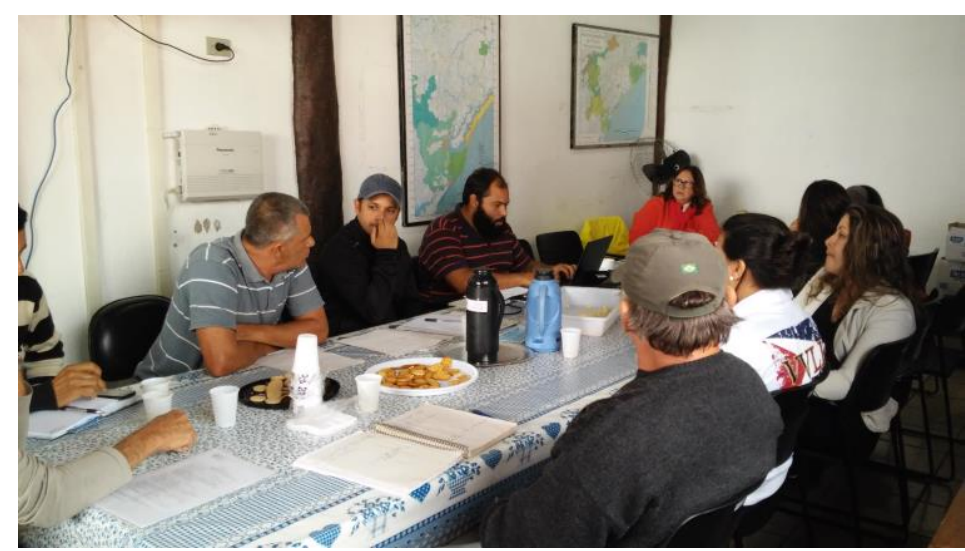

Figura 12 - Reunião do Conselho Gestor na base do PEIC, em Cananéia.

Fonte: Autora, 2015.

Morador tradicional do Marujá relata que em outras gestões do PEIC não havia qualquer possibilidade de ajuda financeira, e a AMOMAR arcava com os custos de deslocamento do conselheiro do Marujá para as reuniões. No entanto, é preciso considerar que a comunidade do Marujá recebe um fluxo alto de visitantes durante o ano e possui estrutura e recursos disponíveis, o que não necessariamente reflete a realidade das outras comunidades. Atualmente, o conselheiro do Marujá recebe o combustível da gestão do parque, mas trata-se de um acordo individual firmado entre a gestão e a comunidade do Marujá.

Nos primeiros anos do conselho, na gestão do Marcos Campolim, as reuniões eram itinerantes e ocorriam nas próprias comunidades, facilitando a participação dos moradores. Além desse incentivo à participação, os conselheiros também tinham a oportunidade de conhecer melhor as diferentes realidades locais e as demandas e necessidades de cada comunidade.

De acordo com o gestor atual, há interesse do parque em voltar a fazer as reuniões nas comunidades, mas as dificuldades logísticas impossibilitam que se implante essa mudança.

O histórico das reuniões do conselho sempre teve reuniões itinerantes nas comunidades. Devido a algumas dificuldades logísticas é inviável fazer reuniões nas comunidades... Então, elas têm acontecido na sede 
administrativa. A vontade é que volte a ser itinerante, mas no momento a gente não consegue (Atual gestor do PEIC, entrevista concedida em 2015).

Uma das primeiras mudanças instituídas pelo atual gestor, em 2014, foi aumentar a frequência das reuniões, de bimestrais para mensais, seguindo solicitação do próprio conselho gestor. Também já houve uma reunião que ocorreu na comunidade do Itacuruçá/Pereirinha, em 20 de outubro de 2015, no Núcleo Perequê. A ideia surgiu espontaneamente durante uma reunião do conselho e foi acatada tanto pelo gestor quanto pelos conselheiros. Além de contribuir para aproximar todos os participantes, também foi importante para aproximar os conselheiros da realidade local do parque e das comunidades tradicionais. Convém destacar que havia conselheiros que sequer conheciam o parque. Essa aproximação entre os conselheiros e com a comunidade ainda contribui para fortalecer as interações, aumentar a confiança e estreitar os laços entre os participantes.

\subsubsection{Compreensão dos assuntos discutidos}

Em geral, há uma compreensão dos assuntos discutidos durante as reuniões, principalmente entre os conselheiros que participam do conselho há muito tempo.

No entanto, há muitos conselheiros e participantes que não têm conhecimento das normas do conselho, a exemplo do estatuto e do regimento. Isso ocorre por diversos motivos, de acordo com os entrevistados: há os que não têm interesse, há os acham que não irão entender e há os que não têm muito acesso às informações. Há, inclusive, aqueles que participam, mesmo sem entender muito bem, apenas para representar a comunidade. Os moradores reconhecem que a linguagem muitas vezes é difícil, principalmente quando se trata de discutir normas, decretos e leis formais.

Considerando as comunidades que participam do conselho, os conselheiros e moradores do Marujá são citados como exemplo e referência no conhecimento das normas formais e informais, além de possuírem registro de tudo o que já aconteceu no âmbito do conselho. Entre os moradores do Itacuruçá/Pereirinha, observa-se que o conhecimento não é total, mas em geral eles são bem ativos e questionadores durante as reuniões. Já os 
conselheiros da Enseada da Baleia são mais quietos, com poucos comentários e questionamentos durante as reuniões.

Foi possível notar que as reuniões do conselho se constituem de um espaço democrático, que possibilita uma abertura e dá voz aos participantes para dúvidas, esclarecimentos e até posicionamentos. No entanto, como em qualquer espaço de discussão, há participantes que simplesmente não perguntam ou mesmo questionam as informações.

Para o gestor, essa é uma questão delicada, que deve ser tratada com muito cuidado. Ele reconhece que há diferença entre os conselheiros quanto ao entendimento de diversos assuntos e que lidar com essa diferença não é uma questão simples, na medida em que devem ser considerados tanto o conhecimento formal, mais relacionado a regras e normas, quanto o conhecimento informal, mais ligado ao saber popular e às culturas locais. Nessa atual gestão, nota-se um cuidado, na maioria das vezes, de homogeneizar o conhecimento e fazer com que todos os participantes entendam o que está sendo discutido. Isso muitas vezes não é possível, já que há diversos participantes, e as particularidades podem passar desapercebidas.

Não é porque uma pessoa tem mais formação que ela vai saber mais daquilo. Uma pessoa com formação legal pode não ter o histórico do conselho, por exemplo. Ou uma pessoa da comunidade pode não entender os trâmites dentro da Fundação, então são questões diferentes. Então há diferença, sim, e precisamos ter cuidado para envolver todo o conselho nisso, né... Porque muitas vezes não entendeu, mas balança a cabeça com $\mathrm{OK}$, mas não participou daquilo. (...) Estamos falando com pessoas com diferentes vivências. Tanto o uso de um linguajar tradicional caiçara quanto um termo técnico podem não ser familiares. Aí volta o cuidado de pedir para o fulano explicar a palavra quando a gente percebe que alguém não entendeu (Atual gestor do PEIC, entrevista concedida em 2015).

A necessidade de capacitação é uma demanda tanto para o gestor quanto para alguns conselheiros. Há uma necessidade de que todos os conselheiros tenham conhecimento e entendimento a respeito do estatuto e do regimento do conselho, assim como do Plano de Manejo do PEIC, já que as decisões do conselho devem ser tomadas com base nessas normas. 0 gestor reforça que qualquer conselho gestor precisa de capacitação para que cada um possa compreender seu papel dentro desse espaço e como pode contribuir para a unidade de conservação. No entanto, ele reconhece que não há capacidade operacional para implementar medidas para tanto. 


\subsubsection{Decisões}

As decisões tomadas durante as reuniões do conselho são embasadas nas discussões entre os participantes. Em geral, todas as questões são postas em votação. É possível notar que a busca pelo consenso é uma constante. No entanto, não sendo possível alcançar o consenso, vence o voto da maioria. A divergência ocorre em muitos casos, tornando algumas discussões bem calorosas.

Seguindo as regras do conselho gestor, apenas quem é conselheiro de fato tem voto válido nas reuniões. No entanto, mesmo os participantes que não são conselheiros têm espaço para expor suas opiniões e para entrar nas discussões. Foi possível notar que as discussões e o posicionamento dos participantes frente aos assuntos colocados são muito mais importantes do que o processo de votação em si. 0 conselho gestor abre espaço para essas discussões, não importando o tempo que elas durem, sendo que assuntos mais polêmicos podem durar horas de discussão. No caso das discussões a respeito da solicitação de construção de casa por uma antiga moradora (como já pontuado anteriormente), o debate durou cerca de três horas. Esse assunto, inclusive, também foi pauta de outras reuniões do conselho. Observa-se que, em muitos casos, o conselho acaba dispensando muito tempo em determinados assuntos, mesmo em casos em que a decisão já foi tomada.

Alguns conselheiros ressaltam a importância dos participantes e, em especial, dos conselheiros conhecerem de perto as comunidades, de maneira que se aproximem das realidades que estão sendo discutidas durante as reuniões. Há uma crítica a respeito de haver conselheiros que sequer conhecem as comunidades e a ilha: "como o cara vai votar uma coisa se não tem o conhecimento?". Para Ezequiel Oliveira, morador tradicional do Marujá, trata-se de uma questão muito delicada, pois alguns assuntos discutidos e votados em reunião afetam diretamente as dinâmicas e práticas sociais das comunidades.

De acordo com entrevistada, as reuniões itinerantes propiciavam essa aproximação. A presença dos conselheiros nas comunidades, ouvindo as demandas locais e em contato com as diferentes realidades, representava, de certa maneira, uma forma de analisar todo o processo de modo mais humano. E isso é especialmente relevante se 
considerarmos que as comunidades são diferentes e apresentam dinâmicas sociais diferentes.

Se inteirar mais e ter ponto de vista formado para o momento. Porque cada momento requer uma reflexão, e, se você vai passando batido, o direito do morador pode estar sendo ferido e ninguém toma uma postura. Essa postura de liderança precisava ter. Eles precisavam ter dentro do conselho uma liderança melhor formada, liderança não é uma coisa... É uma coisa meio nata a liderança, mas ou se aprimora ou ela se aniquila se não tiver uma evolução de reciclagem (Morador tradicional do Marujá, líder da comunidade, entrevista concedida em 2014).

As lideranças das comunidades, nesse contexto, assumem papel fundamental na defesa dos direitos dos moradores locais. Sobretudo nesse contexto em que nem todos os votos são embasados em conhecimento de fato, a presença de um representante que defenda a comunidade com argumentos reais pode fazer toda a diferença no momento de decisão. No entanto, quando se trata de casos de comunidades ou situações sem representação no conselho, o que vale é o bom senso dos conselheiros e, mais uma vez, seu conhecimento a respeito da situação ou local. O conhecimento da realidade, nesses casos, deveria ser pressuposto para a tomada de decisão.

Nesse contexto, há uma diferença entre as comunidades que é notável nas reuniões do conselho. O Marujá possui liderança forte e posicionamento firme sobre quase todas as questões. Ainda que o posicionamento da AMOMAR não seja unânime em toda a comunidade, ele representa a voz da comunidade em relação à gestão do parque. As outras duas comunidades possuem dinâmicas diferentes. A AMOIP tem uma gestão mais descentralizada, sendo que não há uma liderança, e sim várias. 0 voto nas reuniões é centralizado na AMOIP, mas nos processos de argumentação sempre há várias vozes com argumentos diversos. Já a Enseada da Baleia tem participação menos constante nos processos de discussão no conselho e argumenta mais quando se trata de assuntos relacionados mais diretamente à sua comunidade. Apresentam uma gestão também mais descentralizada, mas tendendo a focar na atuação de sua atual liderança, ao menos no que se refere à gestão do parque.

Alguns conselheiros salientam que nem todas as decisões entre a gestão e as comunidades são tomadas dentro do conselho gestor. Em algumas situações, ainda que a decisão final se dê durante a reunião do conselho gestor, diversas ações são feitas fora das reuniões. Há interações que ocorrem a todo o momento entre as comunidades, entre 
as comunidades e o gestor e que envolvem também participantes e pessoas externas ao conselho. Tais interações são de suma importância, pois representam essa aproximação dos atores em prol de interesses coletivos ou que venham a beneficiar comunidades não representadas no conselho.

Essas articulações podem ocorrer também como complemento ao próprio conselho gestor, a exemplo das Câmaras Temáticas ou dos Grupos de Trabalho formados para debater temas específicos. Nesses grupos, não apenas ocorrem as reuniões fora do conselho gestor, mas demandam em geral articulações que extrapolam o tempo e os limites das reuniões. São de fundamental importância para aproximar as comunidades da gestão e dos processos decisórios.

Além disso, podemos considerar também as próprias associações comunitárias como espaços de decisão e acordos que extrapolam o âmbito do conselho gestor. Muitas das decisões não são, inclusive, repassadas ao conselho gestor, nos casos em que não afetam o parque diretamente. Assuntos específicos do âmbito da comunidade, alguns assuntos de uso público e turismo e assuntos que envolvem as normas de convivência da comunidade são decididos pelas próprias comunidades. As decisões que afetam diretamente a unidade de conservação ou a gestão do parque em si são repassadas ao gestor ou durante as reuniões do conselho.

Alguns conselheiros ainda reforçam que há decisões "de cima para baixo", tomadas pelas instâncias superiores de gestão, que não são discutidas em conselho, a exemplo das obras de reforma do Núcleo Perequê, que acabaram gerando uma série de transtornos e que não foram informadas ou debatidas em conselho, de acordo com os conselheiros. Esse tipo de decisão acaba atrapalhando as dinâmicas que geralmente ocorrem no conselho e entre os atores. Como consequência, temos, muitas vezes, decisões arbitrárias que acabam influenciando todo o processo de interação e confiança conquistado.

\subsubsection{Poder do conselho}


De acordo com as normas ambientais, os conselhos gestores de parques devem ser obrigatoriamente consultivos, o que limita, em teoria, o seu poder de atuação, já que não são passíveis de deliberar. Trata-se de um órgão de consulta, e não de deliberação.

O conselho gestor do PEIC, no entanto, em vários momentos de sua história, atuou muito mais como um conselho deliberativo do que como um conselho meramente consultivo.

Alguns conselheiros argumentam que o conselho consultivo não tem poder de deliberar, mas contribui para ajudar o gestor a gerir o parque. Há quem defenda que o poder do conselho está relacionado em grande parte ao perfil do próprio gestor. Como se trata de um poder discricionário, cabe ao gestor, em diversas situações, escolher pelas opções que mais lhe convém. Os entrevistados afirmam que o PEIC já contou com gestores que acreditavam no conselho e se empenhavam para encaminhar as propostas discutidas pelos conselheiros, assim como também já contou com gestores que não davam tanta importância para o conselho.

Observa-se que a base do conselho está justamente nos conselheiros e nas pessoas que participam assiduamente das reuniões e não necessariamente na figura do gestor. Ezequiel Oliveira argumenta que a força do conselho vem dos próprios conselheiros e da compreensão do desafio que se tem em aliar a questão ambiental e a vida do morador tradicional em uma unidade de conservação. Para ele, ter clareza desse desafio é uma das principais questões para garantir que o conselho gestor tenha poder de fato, independentemente do perfil do gestor.

0 poder é limitado, primeiro porque, quando do Plano de Gestão, o conselho deveria ser deliberativo, e o Estado não deixou. Aí virou conselho consultivo. Aí veja, na gestão do Marcos, ele pegava o que o conselho determinava, virava... Era colocado na ata da mesma forma, e era encaminhado o processo para a Fundação, era o IF primeiro, depois $\mathrm{FF}$, e ele trabalhava em cima daquilo lá. 0 conselho teve um momento muito bom, com pessoas bem mais claras e mais responsáveis, teve um momento fraco, momento que não sabia bem o que queria, deixava se enrolar pelo gestor, com seu discurso. Então esse conselho muda e é muito frágil ainda hoje. Eu não sinto assim tanta segurança nele. Por que eu falo isso? Porque as principais pessoas que deviam estar ajudando na responsabilidade desse conselho são os moradores, os representantes das comunidades. Porque não é só chegar lá no conselho e achar que queremos tudo de qualquer maneira. Nós temos que entender que nós estamos dentro da unidade de conservação, e tem que ser levado a sério a questão ambiental, e tem que ser levado a sério a vida do morador. E como a gente casa isso? Como lidar com essa questão? 0 conselho não 
tem clareza disso (Morador tradicional do Marujá, líder da comunidade, entrevista concedida em 2014).

Para o gestor, o conselho é umas das principais ferramentas das quais o parque dispõe para garantir uma gestão eficiente e participativa, juntamente com o Plano de Manejo. Essa visão reflete o posicionamento do atual gestor, que possui uma proximidade maior com as questões relacionadas à gestão participativa, ainda que represente os interesses da Fundação Florestal. 0 modo como o gestor entende, gera e enfrenta o conselho gestor diz muito sobre o modo como se relaciona com as próprias comunidades e suas demandas.

O conselho é a principal esfera de gestão da unidade, e o papel dele é fazer a gestão participativa da unidade. Um dos principais suportes do gestor é o conselho e o plano de manejo. Pode não ser exclusivo, mas a base é balizada por esses dois instrumentos. Na minha opinião, é fundamental que se passe pelo conselho as maiores demandas. Para aprovação e ciência do conselho (Atual gestor do PEIC).

Há que se considerar também que o órgão gestor de um parque estadual paulista é a Fundação Florestal, e muitas das decisões finais fogem do âmbito do gestor. E assim como há perfis diferentes de gestores, há também perfis diferentes de pessoas responsáveis pelas decisões no âmbito da Fundação Florestal.

Enquanto conselho, eu não sou gestor da unidade, mas as decisões do conselho muitas vezes são consolidadas e efetivadas pela gestão. Se sai uma decisão que eu (como gestor) não concordo totalmente, é o conselho que está tomando a decisão, e aí eu encaminho da mesma forma. $\mathrm{O}$ que eu posso fazer é construir todo o respaldo argumentativo e aí encaminhar para análise superior. Aí foge um pouco da esfera do conselho e da UC (Atual gestor do PEIC, entrevista concedida em 2015).

Reitera-se aqui a influência do perfil do gestor na força que o conselho gestor tem perante a própria instância superior de gestão, a saber a Fundação Florestal. Esse tal poder discricionário do gestor vai, em certa medida, delinear o poder do conselho gestor na tomada de decisão final.

\subsubsection{Dificuldades e desafios do conselho}


É consenso entre os conselheiros as dificuldades relacionadas ao andamento das decisões e solicitações no âmbito do conselho gestor. "O principal desafio é fazer com que as decisões saiam do papel, que as coisas andem" (Moradora tradicional do Itacuruçá, presidente da AMOIP, conselheira no CONSELHO GESTOR do PEIC, entrevista concedida em 2015). Principalmente no tocante às comunidades tradicionais que, em geral, são as mais impactadas pela morosidade dos processos, o principal desafio do conselho é acelerar os processos e demandas das comunidades tradicionais. Reconhecem, no entanto, que não há estrutura adequada para que a gestão seja mais eficiente, a exemplo do baixo número de funcionários e da falta de recursos.

0 excesso de burocracia também foi indicado por alguns como um aspecto que atrapalha o andamento dos projetos e ações. São muitos processos burocráticos e administrativos que fogem ao controle do gestor, mas que acabam influenciando as interações, a participação das comunidades e até a própria confiança na gestão.

Eu acho que não é má vontade do gestor. É burocracia da FF, eu acho que o gestor até gostaria de chegar e falar que o banheiro será liberado etc. Mas não é. Isso já vem da FF. Não é do gestor. 0 gestor tem boa vontade, de tentar ajudar, eles conseguem entender nosso lado, então a gente tenta, junto com ele, fazer alguma coisa que você não tem certeza se vai funcionar (Moradora tradicional do Itacuruçá, presidente da AMOIP, conselheira no Conselho Gestor do PEIC, entrevista concedida em 2015).

De acordo com o atual gestor, são três as principais dificuldades: estrutura física e de recursos humanos deficientes, ausência de recursos monetários e dificuldade em estabelecer parcerias. $O$ gestor reconhece que a gestão do PEIC tem dificuldades para operacionalizar muitas das decisões tomadas durante as reuniões do conselho. Muitas vezes, trata-se de decisões que foram discutidas por muito tempo, inclusive considerando alternativas de implementação, mas na prática as dificuldades acabam deixando o processo todo muito lento. No entanto, como afirma o próprio gestor, algumas mudanças levam tempo para ser implementadas, a exemplo do Plano de Uso Público do Itacuruçá e Pereirinha, elaborado pelo conselho gestor, que ainda está em implantação.

A participação mais constante e efetiva das comunidades também é outro desafio. Inserir as comunidades mais distantes da gestão, que sequer participam das reuniões do conselho, é de suma importância para garantir, de um lado, uma gestão mais eficiente, e 
de outro, direitos efetivos para essas comunidades. Para alguns conselheiros, as reuniões itinerantes poderiam incentivar a participação dessas comunidades nas reuniões. Para outros, a necessidade da inclusão vai além de se aproximar dessas comunidades mais distantes, sendo necessárias ações de inclusão também de jovens e mulheres, em geral marginalizados do processo em boa parte das comunidades.

Durante as reuniões do conselho, foi possível observar que há uma certa dificuldade em lidar com as normas e regras, considerando comunidades tão diferentes entre si. São recorrentes as falas que ressaltam que as regras são, em grande parte, voltadas para a realidade da comunidade do Marujá, e não se adequam totalmente às realidades das outras comunidades.

A instabilidade institucional da Fundação Florestal e, consequentemente, da gestão do parque, com as frequentes trocas de gestão, é um grande desafio no que se refere aos processos e às dinâmicas das reuniões do conselho, que dependem muito do perfil do gestor.

Para Ezequiel Oliveira, o grande desafio do conselho é a sua falta de clareza enquanto instituição participativa que deveria se fortalecer independentemente do gestor. Segundo ele, o conselho deveria ter muita clareza de suas possibilidades e de sua atuação em relação à conservação ambiental e aos direitos das comunidades tradicionais.

Faltam mais responsabilidade e mais reflexão por parte do conselho, eu acho que o conselho tinha que, de vez em quando, se reunir ele só e debater isso... 0 que nós vamos apoiar, o que nós queremos, qual é o trilho, para não embarcar na conversa do gestor ou a deliberação que a Fundação Florestal faz. Por exemplo, essa que eles não querem aceitar a venda de morador tradicional para outro morador tradicional que não tem moradia. Isso é burro duas vezes, pelo menos. Primeiro porque o morador tradicional que vai embora não vai vender para veranista, para qualquer um. E segundo que é uma obra a menos, porque o cara que precisa de moradia não vai construir outra (Morador tradicional do Marujá, líder da comunidade, entrevista concedida em 2014).

Outra questão levantada como desafio do conselho gestor é sua atuação limitada apenas nas questões internas ao parque. Assuntos relacionados às questões externas que influenciam ou possam vir a impactar as áreas do parque não são discutidos ou mencionados durante as reuniões do conselho. 
Eu acho que é saber gerir o entorno do parque as questões que estão por vir. Tem muitas pressões na região chegando. Porque, aos poucos, essas comunidades invisíveis ajudaram a região a ter vários recursos que são extremamente importantes para quem tem interesse em fazer algum tipo de exploração. Então, tem muita coisa acontecendo na região. Eu acho que o conselho sempre se preocupou demais com o que estava lá dentro, e a gente tem ferramentas de trabalho já bem interessantes. A gente tem mecanismo para impedir que uma barraca temporária seja colocada na praia, e a gente não tem mecanismo para impedir que um catamarã atraque e deixe quatro casas caírem num piscar de olhos. E eu fico imaginando que a gente parou de olhar em volta em algum momento. E eu acho que o conselho talvez tenha que começar a olhar para isso (Ex conselheira no Conselho Gestor do PEIC e participante assídua das reuniões do conselho, entrevista concedida em 2015).

A entrevistada lança luz a uma questão de suma importância e que nenhum dos outros entrevistados mencionou, qual seja a inexistência de regras que contemplem ações de agentes externos. Durante as reuniões, foi possível observar as dificuldades enfrentadas pelo conselho e pela própria gestão, por exemplo, para lidar com o caso da embarcação que foi responsável pela derrubada de quatro construções na Enseada da Baleia. De fato, no âmbito do conselho e das comunidades, inúmeras regras de visitação e de convivência foram criadas, mas não há regras específicas ou mesmo procedimentos para lidar com tais ameaças externas, o que põe em risco não apenas a sobrevivências das comunidades tradicionais, mas também o patrimônio natural preservado do parque.

Por fim, apresenta-se como grande desafio do conselho também lidar com o seu poder limitado, principalmente quando se trata de decisões tomadas diretamente pelas instâncias superiores. A rigor, o conselho de um parque não tem o poder de deliberar, portanto, não há qualquer mecanismo legal que faça com que o conselho tenha poder nas decisões tomadas pelos órgãos gestores. E isso pode implicar em ações arbitrárias, sem consulta às comunidades e aos atores envolvidos. Como lidar com isso é desafio enorme não apenas para as comunidades, mas também para a gestão do parque, que muitas vezes atua como porta voz e intermediadora entre as instâncias superiores de gestão e as comunidades.

\subsection{Gestão e mudanças institucionais}


De acordo com Ostrom (1990), a capacidade de gestão nas arenas e em situações de ação, ou mesmo a capacidade de resolver problemas, fica limitada nos casos em que há mudanças institucionais que possam afetar as regras, o monitoramento ou os procedimentos, motivando os atores a adotar diferentes estratégias e comportamentos e, consequentemente, afetando os resultados. Os estudos empíricos demonstraram que a capacidade coletiva de resolução de problemas pode ficar limitada, quando indivíduos não têm expectativas quanto à confiança mútua e à construção da confiança por meio das constantes interações; quando existe falta de confiança e comunicação; e quando os atores não têm autoridade para criar suas próprias instituições autogovernáveis.

É sempre possível que indivíduos e coletivos usem suas capacidades de reflexão, comunicação e comprometimento para desenhar novas regras e para resolver problemas de recursos comuns ${ }^{15}$ (OSTROM, 1990, p. 211).

A autora argumenta que indivíduos e coletivos possuem sempre a capacidade de criar novas regras para resolver problemas novos. Os participantes, seja individual ou coletivamente, podem optar por mudar as regras em uso, causando mudanças nas relações interorganizacionais, ou mesmo alterar essas próprias relações.

A descontinuidade nos processos de gestão, acarretada em grande parte em virtude das constantes trocas de gestores das unidades de conservação, acabam por dificultar o desenvolvimento de estratégias que busquem minimizar os conflitos existentes entre comunidades e poder público. Trata-se de um processo que demanda aproximação e interação com as populações residentes e com as lideranças dos grupos locais, algo que nem todos os gestores estão dispostos a pôr em prática. O PEIC pode ser utilizado como exemplo concreto das influências desses processos de descontinuidade na gestão, na medida em que contou com gestores diferentes nos últimos anos.

Como observado anteriormente, o PEIC implementou uma experiência de gestão participativa, em meados de 1997/1998, com a elaboração do Plano de Gestão Ambiental, que serviu de base para o Plano de Manejo, aprovado em 2001. No entanto, a partir de 2006, com a primeira mudança na gestão do parque desde o Plano de Manejo,

15 "Its often possible for individuals and organizations to use their capacities for self-reflection, communication, and self-commitment to design new rules to solve CRP problems" (OSTROM, 1990, p. 211). 
observa-se uma interrupção dos processos e diálogos que vinham sendo mantidos entre o parque e as comunidades. Como exemplo, as reuniões deixaram de ser itinerantes, fazendo com que muitas comunidades deixassem de participar ao longo dos anos; e alguns gestores eram pouco solícitos às demandas das comunidades, e muitas das solicitações sequer chegavam aos órgãos gestores.

De acordo com Marinho (2013), o PEIC passou por diversos momentos desde a elaboração do plano de manejo, que influenciaram os arranjos de governança e as propostas de gestão participativa iniciadas naquela época. Com a instituição do SIEFLOR em 2006, todas as UCs que estavam sob a gestão do Instituto Florestal passam para a responsabilidade da Fundação Florestal. Surgem ainda diversas demandas à Fundação Florestal, que acaba por acumular unidades de conservação, projetos e demandas que até então não estavam sob sua responsabilidade.

Observa-se, no caso do PEIC, que a partir da instituição do SIEFLOR houve diversas trocas de gestão (vide Figura 13): em 2007, o gestor Marcos Campolim assume outra unidade de conservação, enquanto Mário Nunes assume o PEIC; em 2009, assume o gestor Thiago Borges Conforti; em 2011, a gestora Jeannete Vieira Gennen; em 2012, a gestora Márcia Santana Lima; e, finalmente, em 2014 assume o gestor Edson R. Nascimento, que se mantém até os dias de hoje.

A constante troca de gestores, em muitos casos, acarreta também mudanças no que se refere não apenas às estratégias de ação para a preservação dos recursos naturais, mas, sobretudo, ao diálogo estabelecido com as comunidades residentes nos limites do parque. De certa maneira, quando mudam os gestores, diversas ações e projetos são interrompidos e muitas vezes até descontinuados.

No âmbito do conselho gestor, observam-se alterações tanto nas interações entre comunidades, gestor e demais atores, mas também nas próprias regras formais, na medida em que o poder discricionário do gestor possibilita que haja alternativas diferentes para um mesmo problema, pela via legal, mas sobretudo mudanças nas regras informais. As interações se perdem e o diálogo precisa ser novamente reconstruído. E nesse contexto as relações de confiança estabelecidas ao longo do tempo acabam se perdendo também, juntamente com as expectativas. 
Figura 13 - Linha do tempo da gestão do PEIC

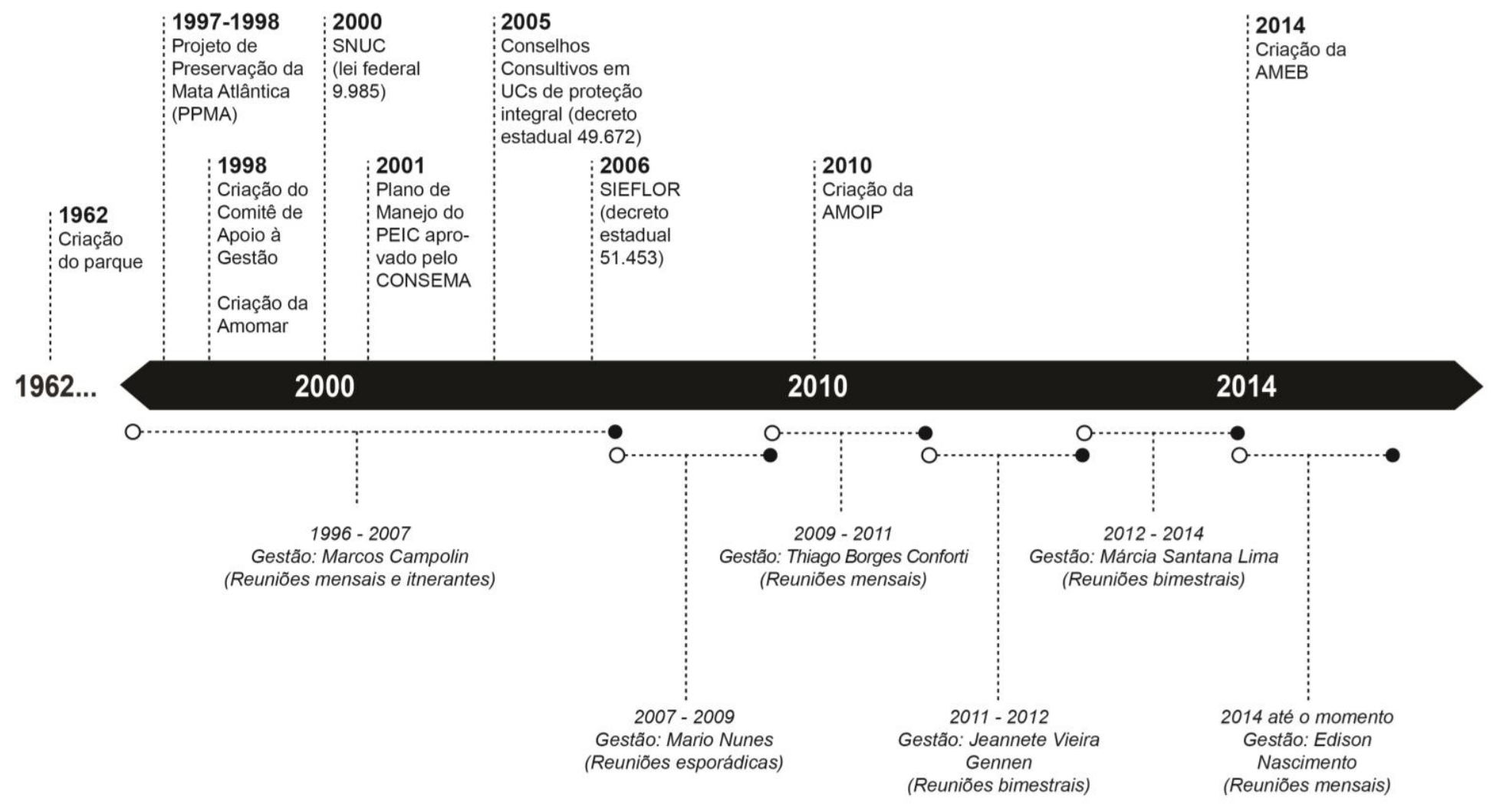

Fonte: Rafael Mantarro, 2016. 
Para Ostrom (1990), a construção e manutenção de compromissos é fundamental para minimizar esses impactos advindos das mudanças institucionais. A compreensão e o entendimento das regras e dos acordos firmados, bem como a maneira como elas operam e interagem com os diferentes atores, possibilitam que os arranjos e as interações sejam menos impactados durante os processos de mudança. Para participante das reuniões, o conselho do PEIC, desde sua fundação, construiu arranjos, normas e acordos que possibilitaram que não houvesse alterações profundas, mesmo com as trocas por gestores com perfis diferentes, mais ou menos afeitos à participação.

Eu acho que o gestor já entra nessa condição. Se ele for muito conservador, a turma não dá ouvido, começa a haver ruído na comunicação. Como o Edison é filho da casa, eu acho que a turma tem muita confiança nele. E eu acho que é um espaço de formação política (Ex conselheira no Conselho Gestor do PEIC e participante assídua das reuniões do conselho, entrevista concedida em 2015).

A entrevistada ainda argumenta que o conselho funciona até hoje como um espaço de formação política, onde todos os participantes têm voz, inclusive aqueles que não são conselheiros, embora não tenham voto. Nesse contexto, observa-se que houve gestores mais abertos, que propiciavam esse ambiente de diálogo e eram receptivos às demandas das comunidades, assim como houve gestores que não eram tão abertos ao diálogo. No entanto, mesmo com esses gestores menos abertos à participação, observa-se que o conselho não se esvaziou. As comunidades em geral relatam que foram momentos mais difíceis, em que as interações eram menores, as dinâmicas eram menos fluidas e os resultados nem sempre muito satisfatórios, mas as três comunidades, em especial, nunca deixaram de participar, até como uma maneira de não se distanciar da gestão e de marcar presença no conselho.

Vou voltar a citar o nome do Marcos Campolim, porque ele, para mim, é uma referência muito boa. E ele é muito aberto a conversa, sempre foi. E ele trabalhou muito com a comunidade. Muito mesmo. Não mandava recado. Ele ia lá, reunia os moradores, conversava. E ele trabalhou muito na questão da educação ambiental, da parte da preservação da ilha, da nossa comunidade também. E entraram alguns gestores bons também, mas infelizmente quando eles estão começando a montar um negócio legal, que a comunidade está interagindo, quando a gente sente que eles estão ajudando, pronto, ah, vai sair... (Moradora tradicional do Itacuruçá, presidente da AMOIP, conselheira no Conselho Gestor do PEIC, entrevista concedida em 2015).

Então, eu vejo que a Fundação Florestal também é outra coisa estranha, muda o Secretário de Meio Ambiente, muda o Diretor da Fundação 
Florestal, muda todo o pessoal, funcionários de alto escalão. E vêm ideias diferentes, quer dizer, quando muda é um transtorno (Morador tradicional do Marujá, líder da comunidade, entrevista concedida em 2014).

De maneira geral, as comunidades têm consciência de que o poder de atuação do gestor da unidade de conservação é limitado, e muitas vezes as decisões são tomadas nas instâncias centrais desses órgãos, a exemplo da Fundação Florestal e da Secretaria de Estado do Meio Ambiente. Esse nível de consciência, de alguma forma, contribui para aproximar as comunidades do gestor, na medida em que há a consciência de que muitas decisões devem ser encaminhadas diretamente para a Fundação Florestal.

De qualquer maneira, é inegável a importância do gestor como burocrata de rua, facilitador na linha de frente intermediando o órgão gestor e os demais atores que participam da arena. 0 perfil do gestor vai se refletir diretamente nos arranjos e interações do conselho gestor e vai delimitar os limites de participação das comunidades na gestão do parque.

Retomando o histórico do PEIC, foi fundamental o papel do gestor no momento de criação e de desenvolvimento do conselho. Sua atuação, de alguma maneira, contribuiu para fortalecer os arranjos institucionais e as interações no conselho e, consequentemente, fortalecer a participação das comunidades nos processos decisórios do parque. Ainda que essa atuação por parte da gestão tenha se perdido por alguns anos, os arranjos criados se mantiveram por meio das normas formais e informais criadas no âmbito do conselho, e as comunidades resistiram e se mostraram presentes, mesmo sem as aberturas necessárias ao aprofundamento do diálogo da participação.

Por outro lado, essas mesmas comunidades perceberam, ao longo dos anos, as possibilidades de utilização de outras instâncias possíveis de participação e de decisão, que não apenas as reuniões do conselho, a exemplo do fortalecimento das associações comunitárias e a utilização do recurso do Ministério Público e da Defensoria Pública para tratar questões até então pouco abertas ao diálogo com a gestão do parque e com a Fundação Florestal.

Atualmente, com o retorno de uma gestão mais aberta ao diálogo, os processos de retomada de confiança estão voltando e as comunidades estão novamente se fortalecendo nesse processo de reaproximação com a gestão do parque. 


\subsection{Análise da robustez institucional do conselho, com base nos critérios de Ostrom}

O estudo da participação das comunidades caiçaras na gestão do PEIC, de acordo com o modelo de análise proposto neste estudo, lança luz ao conselho gestor como espaço central onde ocorrem as interações entre os diversos atores que, de alguma maneira, participam da gestão do parque. Não é exclusivo, na medida em que, conforme foi percebido durante as análises, há outros espaços onde interações e acordos também acontecem, mas é fundamental para entender como se dá o desenho institucional no âmbito da gestão do PEIC e da participação das comunidades que residem no seu interior.

Dessa maneira, supõe-se que, quanto mais forte ou robusto for o conselho, maiores serão as chances de que a gestão dos recursos de uso comum seja bem sucedida, o que inclui necessariamente a participação das comunidades nesse processo. Corroborando com os critérios elencados por Ostrom; Mckean (2001), Ostrom, (2011), Simões (2013), cujas recomendações atestam a robustez das instituições, conforme descrito no item 2.3.1 da Abordagem Teórico Conceitual, e apresentadas resumidamente no Quadro 5, a seguir, são tecidas algumas análises do conselho gestor a partir de cada um dos critérios propostos pelos autores. 
Quadro 5 - Quadro resumido das recomendações para uma instituição robusta

\begin{tabular}{|c|c|}
\hline Critérios & Definição \\
\hline $\begin{array}{l}\text { 1. Limites } \\
\text { definidos }\end{array}$ & $\begin{array}{l}\text { Fronteira da comunidade para o uso dos recursos de acesso } \\
\text { comum deve ser clara, com limites bem definidos e com } \\
\text { critérios para o ingresso a grupos de usuários. }\end{array}$ \\
\hline $\begin{array}{l}\text { 2. Congruência entre } \\
\text { apropriação e provisão de } \\
\text { regras e condições locais }\end{array}$ & $\begin{array}{l}\text { Regras de uso dos recursos de acesso comum devem ser } \\
\text { claras e bem definidas, condicionadas à realidade local. }\end{array}$ \\
\hline $\begin{array}{l}\text { 3. Critérios para ingresso a } \\
\text { grupos de usuários }\end{array}$ & $\begin{array}{l}\text { Os grupos de usuários devem estar cientes e de acordo sobre } \\
\text { quem são os membros e quais as normas ou critérios de } \\
\text { elegibilidade considerados }\end{array}$ \\
\hline $\begin{array}{l}\text { 4. Mudanças nas regras de } \\
\text { uso }\end{array}$ & $\begin{array}{l}\text { Usuários devem ter o direito de modificar suas regras de uso } \\
\text { dos recursos de acesso comum ao longo do tempo. }\end{array}$ \\
\hline $\begin{array}{l}\text { 5. Regras devem estar de } \\
\text { acordo com o sistema }\end{array}$ & $\begin{array}{l}\text { As regras de uso devem corresponder ao que o sistema pode } \\
\text { tolerar e devem ser ambientalmente conservadoras para } \\
\text { possibilitar margens de erro. }\end{array}$ \\
\hline 6. Sanções e monitoramento & $\begin{array}{l}\text { As infrações das regras de uso devem ser monitoradas e } \\
\text { punidas, com sanções graduais. }\end{array}$ \\
\hline $\begin{array}{l}\text { 7. Reconhecimento mínimo } \\
\text { dos direitos de organização }\end{array}$ & $\begin{array}{l}\text { Reconhecimento mínimo de direitos pelas autoridades } \\
\text { governamentais, para organização e de estabelecimento de } \\
\text { regras próprias no uso de acesso comum. }\end{array}$ \\
\hline $\begin{array}{l}\text { 8. Mecanismos de resolução } \\
\text { de conflitos }\end{array}$ & $\begin{array}{l}\text { Existência de mecanismos para a solução de conflitos no uso } \\
\text { dos recursos de acesso comum. }\end{array}$ \\
\hline $\begin{array}{l}\text { 9. Conexões institucionais } \\
\text { transescalares }\end{array}$ & $\begin{array}{l}\text { Existência de empreendimentos inter-relacionados, quando se } \\
\text { tratar de um grande sistema. }\end{array}$ \\
\hline
\end{tabular}

Fonte: Adaptado de Ostrom (2010) e Ostrom e Mckean (2001).

\section{Limites claramente definidos (Critério 1) e Critérios para ingresso a grupos de usuários (Critério 3)}

Por se tratar de uma ilha, as fronteiras do PEIC são bem definidas. Por outro lado, a definição da área abrangida por cada uma das comunidades inseridas dentro do parque já não é tão clara.

O zoneamento do parque, elaborado no Plano de Manejo, define as normas de utilização dos recursos naturais. De acordo com o zoneamento, quase $70 \%$ da área total do parque é classificada como intangível, sendo permitido apenas atividades de pesquisa científica. No tocante às comunidades e às atividades que as mesmas podem realizar nos limites do parque, estão restritas às zonas de uso intensivo e extensivo, que somam pouco mais de $3 \%$ do total do parque. 
Quadro 6 - Zoneamento do PEIC, de acordo com o Plano de Manejo

\begin{tabular}{|c|c|}
\hline Zona intangível & $\begin{array}{l}\text { Apresenta o mais alto grau de preservação dentro da UC e deve } \\
\text { permanecer intacta. Não há usos permitidos dentro dessa área, que } \\
\text { representa } 68,5 \% \text { do parque. }\end{array}$ \\
\hline Zona primitiva & $\begin{array}{l}\text { Trata-se de uma zona de transição entre a zona intangível e a de uso } \\
\text { extensivo. Tem como principal objetivo a conservação do meio natural, } \\
\text { mas possibilita atividades de pesquisa científica, educação ambiental e } \\
\text { alguma atividade de recreação - sem dispor de estrutura e } \\
\text { equipamentos, mas com controle no número de visitantes. } 19,0 \% \text { da } \\
\text { área total do parque }\end{array}$ \\
\hline $\begin{array}{l}\text { Zona de uso } \\
\text { extensivo }\end{array}$ & $\begin{array}{l}\text { São áreas com pequena interferência humana aparente. O seu principal } \\
\text { objetivo é a manutenção do ambiente natural com o mínimo de impacto } \\
\text { humano, oferecendo, no entanto, acesso e facilidade para fins } \\
\text { educativos e de recreação. } 2,2 \% \text { do parque. }\end{array}$ \\
\hline $\begin{array}{l}\text { Zona de uso } \\
\text { intensivo }\end{array}$ & $\begin{array}{l}\text { Áreas alteradas pelo homem. Objetiva facilitar a recreação intensiva e } \\
\text { educação ambiental em harmonia com o meio. Concentram as } \\
\text { estruturas e apoio à visitação e as porções territoriais mais alteradas } \\
\text { pela ocupação humana; área onde estão as comunidades tradicionais. } \\
1 \% \text { da área do parque }\end{array}$ \\
\hline Zona de uso especial & $\begin{array}{l}\text { Áreas necessárias à administração, manutenção e serviços do parque. } \\
0,25 \% \text { do parque. }\end{array}$ \\
\hline $\begin{array}{l}\text { Zonas de } \\
\text { recuperação }\end{array}$ & $\begin{array}{l}\text { Zonas notadamente alteradas pelo homem, com objetivo de deter a } \\
\text { degradação dos recursos e restauração. } 9,05 \% \text { do parque. }\end{array}$ \\
\hline $\begin{array}{l}\text { Zona histórico- } \\
\text { cultural }\end{array}$ & $\begin{array}{l}\text { Zonas onde são encontradas manifestações históricas e culturais ou } \\
\text { arqueológicas, que devem ser preservadas, estudadas e interpretadas } \\
\text { para o público. }\end{array}$ \\
\hline
\end{tabular}

Fonte: Adaptado do Plano de Manejo, 2001.

De acordo com a Figura 14 as áreas correspondentes às zonas de uso extensivo e intensivo estão indicadas em laranja e vermelho, respectivamente. Ainda que sejam pequenas, principalmente em relação à área total do parque, representam as áreas onde as comunidades vivem e podem, de acordo com o estabelecido pelo plano, realizar algumas atividades de uso dos recursos. Justamente por isso estão localizadas no entorno das próprias comunidades. 


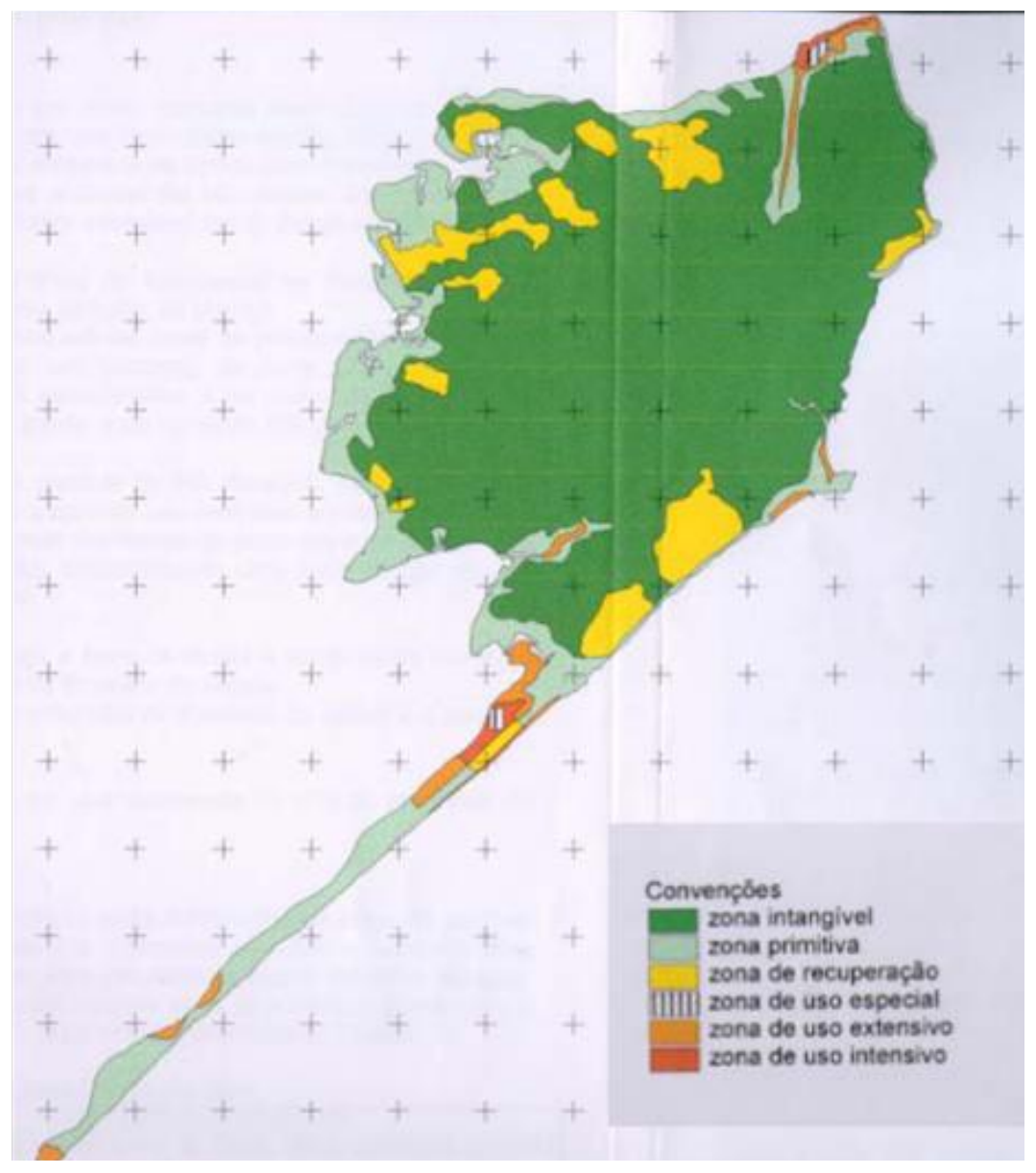

Figura 14 - Mapa do zoneamento do Parque Estadual da Ilha do Cardoso

Fonte: Plano de Manejo, 2001.

No que se refere aos critérios de ingresso para os grupos de usuários - que aqui no contexto serão chamados simplesmente de moradores -, também foram definidos no Plano de Manejo, que descreve, em linhas gerais, quais pessoas têm o direito de permanecer na ilha, assim como as normas para o retorno das famílias ou dos indivíduos que acabaram deixando a ilha.

Ainda que o conjunto de regras tenha sido elaborado de maneira participativa, junto às comunidades, alguns moradores e conselheiros atuais questionam se as normas realmente atendem às realidades locais nos dias de hoje. Alguns argumentam que essas regras são voltadas principalmente à realidade da comunidade do Marujá e não se adequam às realidades das outras comunidades.

Observa-se que as comunidades possuem visões diferentes a respeito das regras de ingresso, o que reflete também a maneira como estão organizadas e como interagem 
com as regras, não apenas no âmbito do conselho e do parque, mas também internamente, dentro da comunidade.

Para o Marujá, por exemplo, as regras de permanência e de retorno à ilha são vistas pelas lideranças como uma maneira de barrar o crescimento desordenado da comunidade e de evitar que interesses externos acabem influenciando as dinâmicas locais. Trata-se de uma comunidade mais heterogênea, com número alto de famílias em relação às outras comunidades.

Por outro lado, as outras comunidades são menores e mais homogêneas, sendo formadas por poucas famílias. Os moradores da Enseada da Baleia comentam que algumas famílias deixaram a ilha em momentos de crise e na busca de outros meios de sobrevivência. 0 retorno à comunidade para essas famílias seria uma vitória conquistada pela comunidade, demonstrando que conseguiram se reestruturar para que as famílias pudessem se manter economicamente e voltar a morar na comunidade.

No caso do Itacuruçá/Pereirinha, parte das famílias atualmente possui casa em Cananéia também. A justificativa para permanecerem parte do tempo em Cananéia está focada na ausência de escola para as crianças na ilha. Ainda que tenham moradia em Cananéia, parte desses moradores tem na ilha e no parque sua base de sustento.

Trata-se de três comunidades com realidades distintas e arranjos institucionais também distintos, mas que devem seguir as mesmas regras elaboradas há mais de 15 anos, o que gera alguns conflitos ocasionalmente. No âmbito do conselho, no entanto, quando surgem assuntos dessa natureza, as comunidades expõem suas opiniões e posições, seja a favor ou contra, e o debate ocorre democraticamente na busca pelo consenso.

\section{Congruência entre apropriação e provisão de regras e condições locais (Critério 2), Mudanças nas regras de uso (Critério 4) e Regras devem estar de acordo com o sistema (Critério 5)}

Considerando o contexto das unidades de conservação no Estado de São Paulo, o PEIC se destaca por ter um Plano de Manejo aprovado desde 2001. Ainda que esteja 
desatualizado, já que deveria apresentar revisões a cada cinco anos, o plano apresenta as normas de uso dos recursos de acesso comum do parque, delimitando onde e quais atividades podem ser realizadas em seus limites, vide mapa de zoneamento apresentado anteriormente (Figura 14).

O principal espaço de discussão coletiva da gestão do PEIC é o conselho gestor. Apesar de ter caráter consultivo, em diversos momentos o conselho apresentou-se muito mais deliberativo do que consultivo.

Na maneira como está posto hoje, trata-se de um espaço democrático, onde conselheiros e participantes têm voz e podem expor suas posições e argumentos. Muitos dos encaminhamentos são enviados para a Fundação Florestal e fogem do âmbito de poder local, da própria gestão do parque, mas há diversos assuntos que acabam sendo resolvidos pela própria gestão junto ao conselho.

As três comunidades participam do conselho desde sua fundação, sendo o Marujá a comunidade mais participativa e ativa nas discussões, seguido do Itacuruçá/Pereirinha e da Enseada da Baleia.

Ainda que o conselho e seus participantes não possam, a priori, modificar as regras estabelecidas no Plano Manejo, historicamente o conselho tem sido a principal arena de acordos formais e informais de uso dos recursos ao longo do tempo, com ampla participação das três comunidades.

Observa-se que as normas não se adequam plenamente às realidades das comunidades locais, justamente por conta do fator ambiental: como se trata de uma unidade de conservação de proteção integral, prevalecem as normas de preservação dos recursos naturais, com uso indireto dos recursos. No entanto, nesses quinze anos de plano de manejo e de existência do conselho, nota-se que as comunidades aprenderam a gerenciar alguns acordos formais e informais com o parque e foram conquistando aos poucos alguns direitos de utilização dos recursos.

As comunidades acabaram encontrando caminhos alternativos a essas restrições de uso dos recursos. 0 desenvolvimento do turismo e o aumento da visitação, nesse sentido, foram de suma importância para garantir a sobrevivência das comunidades no parque, 
já que foram impedidas de utilizar muitos dos recursos naturais que utilizavam no passado, ainda que apenas para subsistência.

Para o Marujá, o turismo já representa atualmente boa parte da economia. A Enseada da Baleia está começando a desenvolver trabalhos com o turismo de base comunitária e vem desenvolvendo iniciativas importantes de economia solidária ${ }^{16}$, por meio do Grupo das Mulheres da Enseada da Baleia. Por meio de atividades alternativas como o artesanato, o manejo de ostras e as técnicas artesanais de secagem do peixe, a comunidade está se adaptando para sobreviver de acordo com as normas do parque.

Ainda que moradores mais antigos reclamem das proibições de fazer roça, de caçar e de derrubar madeira para fazer cercos, as restrições de uso dos recursos continuam existindo. No entanto, as comunidades tiveram diversas conquistas ao longo dos anos, por meio dos acordos formais e informais, com alguns direitos que garantem até hoje sua permanência no parque. E o conselho é o principal espaço onde essas questões, discussões e acordos são trazidos à tona.

\section{Sanções e monitoramento (Critério 6)}

A capacidade de fiscalização da gestão do parque é bastante limitada. Além de ser uma área muito grande, as deficiências de recursos tanto humanos quanto financeiros são um grande entrave para a eficiência da gestão.

No entanto, observa-se que as próprias comunidades analisadas são responsáveis pelo monitoramento e fiscalização, principalmente internamente, em cada uma de suas comunidades. Os relatos de infração são informados ao conselho e à gestão, que aciona a fiscalização após as denúncias.

Essa fiscalização acontece especialmente nas comunidades que efetivamente participam do conselho gestor, já que se trata de uma arena que acaba aproximando gestão e

\footnotetext{
16 "A economia solidária é outro modo de produção, cujos princípios básicos são a propriedade coletiva ou associada do capital e o direito à liberdade individual” (SINGER, 2002, p. 10)
} 
lideranças. Reflete, portanto, a importância de mobilização e sensibilização de todas as comunidades para dentro do conselho gestor.

Há sanções para infrações legais estabelecidas por lei. No entanto, nota-se que há uma flexibilidade em relação a essas infrações, sendo que as sanções muitas vezes são discutidas no próprio conselho e acabam sendo votadas pelos conselheiros.

Algumas comunidades têm utilizado o recurso do Ministério Público para resolver determinadas situações, principalmente em casos em que a gestão não fornece uma resposta ou mesmo uma solução viável, o que tem se demonstrado bastante eficiente, de acordo com os entrevistados. Pode-se citar dois casos: o envolvimento do Ministério Público para lidar com a questão da alocação dos moradores da Enseada da Baleia por conta da erosão; e um caso que ocorreu no Marujá, a respeito da expulsão de um cachorro de uma moradora, que havia sido trazido para a ilha contrariando as regras determinadas pela gestão do parque.

No âmbito interno das comunidades, o Marujá é o que mais apresenta um monitoramento constante em relação ao cumprimento das regras pelos próprios moradores. As sanções, no entanto, são estabelecidas pela gestão do parque e pelo conselho gestor.

\section{Reconhecimento mínimo de direitos de organização (Critério 7) e Mecanismos de resolução de conflitos (Critério 8)}

Como mencionado anteriormente, o conselho é o principal espaço para resolução de conflitos no âmbito do parque. A busca pelo diálogo e o consenso é uma constante nas reuniões da atual gestão do conselho gestor. Há espaço para que cada conselheiro exponha suas posições e argumente suas opiniões em assuntos diversos.

No entanto, por se tratar de uma reunião por mês, dependendo da urgência do assunto, é comum que as comunidades procurem o gestor diretamente. Fica a critério do gestor inserir esses assuntos durante as reuniões do conselho. 
Há um reconhecimento mínimo de direitos para as comunidades, garantido pelo Plano de Manejo e amparado pela lei do SNUC. No entanto, esse reconhecimento é precário, na medida em que as comunidades não possuem a titularidade da terra e estão proibidas de realizar diversas atividades que possam estar relacionadas à utilização dos recursos naturais ou à supressão da vegetação.

Por outro lado, percebe-se que as comunidades conquistaram autonomia no que se refere à gestão da atividade turística em suas comunidades. Há normas formais estabelecidas, assim como normas informais entre os comunitários e com o gestor, mas o controle da gestão do turismo propriamente dito é feito pelas comunidades. Nesse contexto, as associações locais desempenham um papel importante para a gestão e para as próprias comunidades. Muitas questões são resolvidas no âmbito local, interno às comunidades, sem precisar da intervenção de instituições governamentais.

Os acordos formais e informais também são uma constante nas reuniões do conselho. As articulações entre as comunidades e entre comunidades, gestor e atores externos também são de fundamental importância para a dinâmica de gestão do parque e das comunidades, inclusive de assuntos que são resolvidos ou não nas reuniões do conselho. A fragilidade dos acordos informais é um fato que preocupa alguns moradores e conselheiros, principalmente no contexto de mudança de gestor. Muitos dos acordos acabam se perdendo nas trocas de gestão, e os moradores acabam ficando desamparados em muitos momentos. No entanto, é inegável que tais acordos são de suma importância, já que, em muitos casos, facilitam o andamento de processos que muitas vezes permaneceriam barrados por questões burocráticas.

\section{Existência de empreendimentos inter-relacionados (Critério 9)}

Em ambientes muito grandes ${ }^{17}$, é desejável que se distribua estrategicamente o espaço entre grupos de usuários diferentes, de maneira que haja várias comunidades com diferentes graus de inter-relações entre elas. Observa-se que no PEIC há diversas

\footnotetext{
${ }^{17}$ No caso do PEIC, refere-se ao tamanho físico, que conta com 13.500 hectares.
} 
comunidades espalhadas pelo território, que não foram colocadas propositalmente pela gestão, mas que já estavam nessas regiões quando o parque foi criado. Se pensarmos na distribuição como estratégia de gestão, considerando a busca de maior eficiência no monitoramento e fiscalização do parque, todas as comunidades - e não apenas as que já possuem certa proximidade com a gestão - poderiam ser grandes aliadas da gestão do parque, caso fossem de fato integradas no processo. No entanto, não é o que se observa no parque, principalmente no que se refere às demais comunidades, mais afastadas tanto física quanto institucionalmente da gestão do PEIC. 


\section{SÍNTESE DOS RESULTADOS}

A utilização do modelo IAD - Institutional Analysis and Development Framework (OSTROM, 1990) permitiu que se chegasse a algumas considerações a respeito da participação das quatro comunidades analisadas na gestão do PEIC. Compreender o desenho institucional do conselho gestor não foi tarefa fácil, pois demandou entender todo o complexo sistema que envolve uma arena de ação, que vai desde aspectos relativos à organização dos participantes (cultura) até as regras em uso nas arenas e fóruns de discussão e sociabilização. No entanto, o modelo apresentou-se como uma ferramenta eficiente nessa tarefa, principalmente se considerarmos a gestão de uma unidade de conservação de proteção integral com a presença de comunidades em seu interior, o que aumenta os conflitos, e as disputas e interações tornam-se ainda mais complexas.

Longe de querer esgotar o tema, a pesquisa possibilitou o alcance dos objetivos propostos: analisar as possiblidades e conflitos da participação de quatro comunidades caiçaras na gestão do PEIC, a partir dos arranjos das comunidades e do desenho institucional do conselho gestor. Os resultados e análises propriamente ditos foram sendo aprofundados ao longo dos textos apresentados nos capítulos anteriores. A seguir são apresentadas algumas sínteses destes resultados.

\section{A importância do conselho gestor como ferramenta de participação}

Como exposto no referencial teórico, a efetividade dos conselhos gestores como espaço de inclusão e participação vem sendo discutida por muitos autores, principalmente no que diz respeito aos entraves e desafios que permeiam tais arenas, a exemplo do tipo de deliberação (consultivo ou deliberativo), dos representantes, da implementação das ações, da condução das reuniões, das pautas e dos jogos políticos que envolvem não apenas as reuniões em si, mas o interesse em fazer do conselho uma ferramenta de gestão (ABERS; KECK, 2008; ABERS et al, 2010; CÔRTES , 2007; IRVING, 2006; VAZ, 2011). 
Os conselhos gestores de parques são ainda recentes no âmbito das políticas públicas ambientais do Estado de São Paulo. Considerando a maioria dos parques do Estado, a formação dos conselhos gestores foi principalmente resultado de uma política imposta pelos órgãos gestores, tendo sido criados sem as devidas preocupações com os processos de inclusão e participação.

O conselho gestor do PEIC, no entanto, teve um processo gestionário diferente, se consideramos o histórico de criação dos conselhos gestores de parques no Estado. Sua criação contou com um momento propício (Projeto PPMA e possibilidades de participação no planejamento de UCs), lideranças comunitárias ativas e atuantes e um gestor aberto à participação das comunidades.

Passados quase vinte anos desde sua criação, analisando o conselho à luz das recomendações propostas por OSTROM em seu modelo de análise institucional, observa-se que o conselho gestor do PEIC apresenta-se ainda hoje como um espaço democrático, que abre espaço para a participação das comunidades e propõe um diálogo constante com os participantes. Vem sendo utilizado, inclusive, como importante ferramenta na atual gestão do parque.

Esta robustez do conselho é fruto dos acordos formais e informais estabelecidos entre gestão e comunidades ao longo dos anos, o que inclui os processos diferenciados experimentados pelos atores em relação às suas interações e, sobretudo, à participação e articulação das comunidades, principalmente se consideramos a sua disposição para participar, questionar e discutir a respeito dos mais diversos assuntos. Reflete, portanto, o caráter de resistência desses moradores em lutar pela permanência na ilha, mesmo sem ter conquistado até hoje os direitos sobre a posse e propriedade da terra.

Apesar do caráter participativo do conselho gestor do PEIC, algumas ressalvas devem ser feitas. Trata-se de um conselho consultivo e, portanto, não tem o poder deliberativo por lei, cabendo ao gestor e, muitas vezes, à própria Fundação Florestal decidir por instituir ou implementar o que foi decidido pelos conselheiros. Nesse contexto, o perfil do gestor muitas vezes é fundamental para garantir o andamento dos processos e, sobretudo, essa democratização do espaço do conselho.

Algumas questões financeiras e administrativas, a exemplo da falta de recursos humanos e financeiros, também atuam como entraves para a implantação de diversas ações pela 
gestão do parque. Muitas vezes, a pré-disposição do gestor em implementar as ações acaba impactada por tais entraves e dificuldades.

Além disso, o fato de ser um espaço democrático não significa que não demande esforços contínuos das comunidades, já que a presença constante nas reuniões é fator crucial para garantir que o espaço continue sendo participativo. Nesse contexto, observa-se uma deficiência no processo de inclusão, na medida em que há diversas comunidades que estão tão distantes desse processo de gestão e participação, que sequer participam do conselho.

O conselho gestor do PEIC, da maneira como está posto hoje, contribui para minimizar os conflitos entre órgãos gestores e comunidades tradicionais, principalmente se considerarmos o interesse das comunidades analisadas na pesquisa, que são as que mais participam do processo. Não sana os conflitos, já que há outros atores envolvidos no processo de gestão, a exemplo da própria Fundação Florestal e da Secretaria de Estado de Meio Ambiente, mas contribui para colocar os assuntos polêmicos e conflituosos em discussão.

\section{Influência dos arranjos institucionais das comunidades na participação}

Corroborando com o modelo IAD- Institutional Analysis and Development Framework (proposto por Ostrom e adaptado pela autora), as regras são de suma importância no contexto da gestão do PEIC e do seu conselho gestor. As comunidades se apoiam nas regras formais e informais como garantia de permanência na ilha. Ao invés de enfrentar a gestão negando suas regras, como é mais usual quando se trata de conflitos envolvendo unidades de conservação e comunidades tradicionais, utilizam-se delas para se posicionar e resistir.

As comunidades analisadas têm voz no processo atual de gestão do PEIC e participam de fato de algumas decisões que envolvem a gestão, embora ainda haja muitas decisões que são tomadas pela Fundação Florestal, ou mesmo pela gestão do parque, e que são decididas fora do âmbito das comunidades. De qualquer forma, o conselho gestor acaba se posicionando sobre boa parte das questões, mesmo tendo consciência de que a decisão final, muitas vezes, cabe a outro órgão. 
As comunidades possuem arranjos institucionais diferentes, que refletem a maneira como cada uma delas se posiciona no conselho gestor e interage com a própria gestão. Primeiramente, é preciso ressaltar que não há um modelo ideal de arranjo na comunidade, ou mesmo de arranjo no próprio conselho gestor. Há características que aumentam as possibilidades de participação e de envolvimento nos processos de gestão, a exemplo da organização comunitária.

A comunidade do Marujá tem um perfil mais contestador e politizado, e seu histórico de organização garantiu benefícios ao longo do tempo que as outras comunidades, que começaram a se organizar institucionalmente mais recentemente, estão começando a conquistar. Observa-se que, por conta dessa organização, o Marujá tem muita clareza de suas regras e objetivos e os defende muito bem. Ainda que haja discordâncias internas dentro da comunidade, a gestão comunitária é clara e centralizada na AMOMAR. A participação do Marujá no conselho gestor é ativa, constante e bastante incisiva. Seus representantes, tanto os oficiais quanto os ouvintes, fazem questão de se posicionar em todos os assuntos colocados, inclusive os que não têm relação direta com a sua comunidade ou os que não os afetam diretamente.

As outras comunidades estão começando esse processo de compreender o poder comunitário enquanto instituição e organização. A Enseada da Baleia vive atualmente esse amadurecimento institucional e começa a se projetar enquanto comunidade fortalecida. Estão passando, inclusive, por um processo de empoderamento feminino que desafia a própria cultura tradicional caiçara, onde o homem é o provedor e principal responsável pela renda familiar. No entanto, tem uma participação menos ativa em relação às reuniões do conselho gestor. Estão sempre presentes, mas não se posicionam em todos os assuntos, ficando, na maior parte das vezes, mais restritos aos assuntos específicos de sua comunidade.

Já o Itacuruçá/Pereirinha, ainda que tenha se formado institucionalmente antes da Enseada da Baleia, ainda está em processo de organização institucional. Possui uma participação ativa e constante nas reuniões do conselho, mas se posiciona sobretudo enquanto moradores, e nem sempre enquanto associação ou comunidade.

Nesse contexto, é preciso ressaltar a importância das novas lideranças nas comunidades, em especial na Enseada da Baleia e no Itacuruçá/Pereirinha. Esses novos líderes que 
surgem, em geral filhos ou netos dos antigos líderes, são mais questionadores e enfrentam muito mais as regras impostas pelos órgãos gestores, ou ao menos inserem a discussão no âmbito do conselho. Entre os mais velhos há um discurso um pouco mais conformista, ainda que de resistência, em relação ao parque e a todo o arcabouço de regras impostas desde a sua criação.

Observa-se, por exemplo, que começam a surgir, no âmbito das reuniões do conselho gestor, alguns questionamentos em relação à adequação das regras contidas no Plano de Manejo. As discussões envolvem os argumentos das comunidades menores (Enseada da Baleia e Itacuruçá/Pereirinha) em relação às regras serem, em sua maioria, formatadas para o modelo de gestão e de comunidade que existe no Marujá, não sendo mais adequadas, nos dias de hoje, às demais comunidades, que contam com arranjos e formas de gestão muito diferentes do Marujá.

\section{Dinâmicas do conselho}

As dinâmicas observadas durante as reuniões do conselho também demonstram não apenas o processo de participação das comunidades na gestão do PEIC e nas próprias reuniões, mas, sobretudo, como se dão as interações entre os atores e como o gestor se posiciona e atua no meio desse processo.

Como mencionado, as regras são de suma importância no âmbito do conselho. A dinâmica de se ater às regras como garantia é importante, tanto do ponto de vista do gestor quanto das próprias comunidades. No entanto, é preciso estar aberto às novas propostas sugeridas pelos atores, o que demanda, também, muita confiança no processo. Essa confiança na gestão, por parte dos comunitários, já foi abalada inúmeros vezes, principalmente no contexto de trocas de gestor, o que torna o processo frágil em muitas ocasiões.

Durante algumas reuniões do conselho, foi possível observar, por exemplo, a tentativa do gestor em discutir as possibilidades de elaboração de um termo de compromisso com as famílias em cada uma das comunidades, amparado na Portaria 138/2010 da SMA/SP. De acordo com o proposto, o termo serviria para assegurar direitos reais a cada uma das famílias, considerando, inclusive, as particularidades e diferenças entre as comunidades, 
que são sempre temas recorrentes durante as reuniões. Observou-se que, em todas as vezes que o gestor tentava tratar do assunto, havia muita discussão por parte dos participantes, que insistiam em discutir não apenas as regras, mas, sobretudo, todas as experiências e tentativas passadas, e frustradas, de elaboração do termo, que acabaram não tendo resultados concretos.

O mesmo ocorre em muitos outros assuntos colocados em pauta durante as reuniões do conselho. Há sempre a tentativa do gestor de ouvir cada um dos conselheiros, assim como os demais participantes que queiram falar, e de se chegar a um consenso sobre o assunto que está sendo discutido. Muitas vezes, essa dinâmica atrapalha um pouco a evolução dos processos, e os mesmos assuntos acabam sendo discutidos inúmeras vezes.

Se por um lado contribui para maximizar o processo enquanto espaço participativo e democrático, por outro lado, torna os processos demasiadamente lentos. Qual seria o limite entre a descentralização e a centralização para que os processos sejam justos, participativos e ao mesmo tempo eficientes? Talvez seja uma questão a ser respondida em futuros estudos e pesquisas.

Observou-se também que as dinâmicas são afetadas muitas vezes por burocracias e processos administrativos que poderiam ser muito mais eficientes, se tratados de outras maneiras. Por exemplo, em todo começo de reunião é feita a leitura da ata para que possa ser aprovada. Em muitas reuniões, a simples leitura da ata, com assuntos que já foram discutidos na reunião anterior, acaba levando horas, e muitas vezes muitos desses minutos são perdidos apenas com correções de português. Como a reunião ocorre apenas uma vez por mês, o tempo que leva para finalizar a ata poderia ser utilizado para discutir outros assuntos importantes.

0 conselho se reúne apenas uma vez por mês, o que limita o tempo de discussão e o aprofundamento de temas mais complexos. Observou-se que as câmaras temáticas e grupos de trabalho são pouco utilizados pelo conselho gestor. Por meio da leitura das atas, notou-se que, no começo da atual gestão do parque, tais ferramentas eram utilizadas com mais frequência, a exemplo do Plano de Uso Público do Itacuruçá e Pereirinha, elaborado por um Grupo de Trabalho dentro da Câmara Temática de Uso Público do conselho gestor. São ferramentas muito importantes para a gestão, na medida em que possibilitam o aprofundamento de temas mais complexos e conflituosos 
pelos próprios conselheiros e participantes, e poderiam ser utilizadas com mais frequência pelos atores.

\section{Desafios do conselho}

O conselho gestor do PEIC tem importância fundamental como ferramenta de gestão e como espaço de interação entre os atores envolvidos no âmbito do parque. No entanto, como em qualquer espaço democrático, apresenta alguns desafios. Trata-se de um espaço essencial, inclusive na visão das comunidades, que reconhecem sua limitação enquanto conselho consultivo, mas também sabem do seu potencial de influência na gestão.

Observa-se, no entanto, que não há uma clareza geral a respeito da importância do conselho. Nem todos os atores têm consciência desse poder político que tem o conselho enquanto instituição que deveria funcionar como espaço democrático, independentemente do perfil do gestor ou das ações dos órgãos gestores. Em muitos momentos, fica a impressão de que as decisões do conselho "não valem de nada", já que nem sempre são ratificadas pelas instâncias superiores dos órgãos gestores, principalmente quando envolvem questões relacionadas à construção.

No âmbito das discussões do conselho, há uma preocupação focada nos problemas internos do parque e das comunidades, e ao mesmo tempo um descuido em relação aos fatores e ameaças externas. Um exemplo dessa ausência de posicionamento é o caso que envolveu o catamarã, na Enseada da Baleia. Foram necessárias muitas discussões e muitas reuniões, além de uma atuação incisiva da comunidade da Enseada da Baleia para que algumas ações fossem tomadas. Obviamente, demonstrou um enorme senso de coletividade entre todos os atores, em especial da gestão e das comunidades tradicionais, mas também demonstrou que não há regras ou mesmo procedimentos para lidar com as questões externas, que podem ser muito prejudiciais não apenas para as comunidades, mas também para o parque enquanto unidade de conservação.

Outro desafio do conselho diz respeito à inclusão de todas as comunidades tradicionais que estão dentro do parque nos processos de gestão e participação. Para tanto, é preciso considerar não apenas as dificuldades físicas das comunidades em participar das 
reuniões, mas, sobretudo a sua falta de interesse e motivação. Como aproximar essas comunidades da gestão é um grande desafio. Comunidades que estão afastadas do processo de gestão tendem a viver mais à margem e a não fazer parte do sistema de regras acordados entre os atores. Manter a motivação dos conselheiros para que não deixem de participar também se constitui outro desafio, que se mostra constante no processo de gestão. Construir e manter as pontes de confiança entre os atores é de suma importância para garantir a participação e a assiduidade das comunidades.

Por fim, outro desafio é lidar com as decisões vindas das instâncias superiores e com a fragilidade dos acordos firmados com as comunidades. Há um nível de decisão que não inclui, muitas vezes, sequer a consulta ao conselho e às comunidades. Ora, decisões que afetem diretamente a sobrevivência das comunidades e que não contribuam para garantir seu modo de vida deveriam ao menos passar pelo crivo do conselho. Mas muitas vezes não passam. Como lidar com essas decisões é uma questão que o conselho deve buscar resolver, para que haja ao menos alguma garantia de que não serão prejudicadas no processo.

A institucionalização das regras, dos acordos e das parcerias que já existem hoje entre as comunidades e a gestão, por meio de mecanismos formais, poderia contribuir para salvaguardar as comunidades de possíveis decisões arbitrárias.

Tais mecanismos já têm sido utilizados em algumas unidades de conservação e são reforçados inclusive pelo Ministério Público Federal, em publicação recente, intitulada “Manual de Atuação em Territórios de Povos e Comunidades Tradicionais e Unidades de Conservação de Proteção Integral" (MPF, 2014). Entre outras questões importantes abordadas na publicação, há muitos mecanismos que podem e devem ser utilizados por gestores e comunidades, a exemplo das câmaras técnicas dos conselhos gestores, do plano de uso tradicional, do estabelecimento de zonas histórico-culturais antropológicas, dos acordos de gestão e de manejo e até mesmo da revisão dos limites das unidades de conservação de proteção integral, que poderia incluir recategorizações para outros tipos de espaços protegidos. São mecanismos que buscam conciliar a garantia dos direitos das comunidades tradicionais e a preservação dos recursos naturais, mas seu uso ainda é bastante incipiente no âmbito das UCs. 
O contexto atual do PEIC, em que se vislumbram um conselho gestor forte e democrático, comunidades atuantes e participativas, arranjos institucionais fortes e uma gestão aberta ao diálogo e próxima das comunidades, apresenta um cenário propício ao estabelecimento de tais acordos formais. 


\section{CONSIDERAÇÕES FINAIS}

Quando a gente fala em parque a gente pensa em preservação. Então o parque, ele luta para preservar o meio ambiente, e a gente luta para preservar a cultura da comunidade. Eu acho que o que a gente vem tentando fazer com a gestão é tentar juntar as duas coisas, preservar o meio ambiente, preservar a cultura das comunidades, fortalecer isso. Então eu acho que fazer as pessoas se colocarem no nosso lugar é o que precisa, porque você lá em cima pensa em preservação, árvore, planta, bromélias, que é importante. Mas você chega lá e vê que existe vida, família, criança, senhores e senhoras tentando lutar para viver, é uma outra lógica. Acho que dá para viver as duas coisas juntas. E vive muito bem, né? (Moradora tradicional da Enseada da Baleia, presidente da AMEB, conselheira no Conselho Gestor, entrevista concedida em 2015)

\section{- Então o parque foi uma coisa boa?}

- Foi, com certeza, mais boa do que ruim. Tem que resolver essa pendência de como nós continuamos dentro do parque né? Porque se eles fossem inteligentes, certamente, o que eles fariam? Eles viriam aqui e perguntariam: como é que vocês viveram até hoje? Fariam um estudo antropológico de toda essa dinâmica de vida do morador que manteve, com tanta gente, apesar de tudo isso, manteve o parque estável. Então, vamos aprender com vocês, vamos só coordenar a ação de vocês e vamos aprender com vocês. Era isso que tinha que ser feito. Não era impor regra... eles não sabem nada (Morador tradicional do Marujá, líder da comunidade, entrevista concedida em 2014).

O contexto histórico de criação das unidades de conservação de proteção integral no estado de São Paulo é marcado pela imposição de áreas protegidas que, em muitos casos, contribuiu para alterar a dinâmica territorial, social e cultural de inúmeras comunidades tradicionais que já ocupavam o território antes da criação de tais áreas, gerando inúmeros conflitos entre os atores envolvidos ao longo de décadas.

Estudos empíricos e experiências concretas no mundo todo têm demonstrado as possibilidades de se aliar natureza e comunidades. Se por um lado muitas comunidades tradicionais foram responsáveis pela manutenção da biodiversidade em diversos espaços naturais, por outro lado, a criação de unidades de conservação também contribuiu para salvaguardar muitas comunidades dos impactos do capital e da especulação imobiliária. 
O PEIC é um dos poucos lugares onde os moradores tradicionais, apesar da resistência, ainda acreditam no parque e na sua gestão. Reconhecem, em sua maioria, que a criação do parque teve impacto positivo na medida em que os ajudou a se defender da especulação imobiliária e do poder do capital, a exemplo do que ocorreu em boa parte do litoral paulista, onde comunidades locais perderam seus territórios para grandes condomínios e imóveis de segunda residência.

Ao mesmo tempo, é inegável que os moradores têm grande responsabilidade pela manutenção dos recursos naturais na ilha, seja ocupando o espaço contra invasores, seja gerindo o turismo local de maneira comunitária e sustentável, e até mesmo contribuindo para a fiscalização dos recursos naturais e o monitoramento das regras em uso, visto as deficiências de recursos financeiros e humanos que permeiam a gestão de unidades de conservação no Estado. Então por que não aliar conservação e morador tradicional?

O conselho gestor do PEIC constitui-se de um espaço político, inclusive de formação política, que tem muita força, se considerarmos os arranjos que foram sendo construídos ao longo do tempo. A participação das comunidades é fundamental nesse processo. Sem dúvida, o estabelecimento de regras formais e informais ao longo dos anos e as dinâmicas de interação, estabelecidas entre os diversos atores envolvidos e, em especial, entre comunidades tradicionais e gestão, foram responsáveis por garantir diversas conquistas às comunidades. No entanto, são conquistas ainda frágeis do ponto de vista das leis ambientais e das possibilidades de ações arbitrárias que podem ser empreendidas pelas instâncias superiores de gestão, como a Fundação Florestal e até mesmo a Secretaria de Estado do Meio Ambiente.

No âmbito das unidades de conservação de proteção integral, observa-se que as instituições comunitárias, a exemplo das associações que representam as comunidades no PEIC, ainda que sejam fortes, atuantes e participativas, são de certa maneira limitadas, na medida em que as comunidades não possuem a titularidade da terra, ou mesmo a concessão de uso que lhes garanta não apenas alguns direitos de uso dos recursos, mas sua própria moradia. São os órgãos gestores que acabam ditando as regras finais, enquanto as comunidades se agarram aos acordos formais e informais e a algumas prerrogativas da lei que lhes fornecem alguma garantia de permanência no território. 
Esse paradigma da restrição de uso imposto por unidades de conservação de proteção integral tem sido questionado como modelo viável de conservação dos recursos ambientais. Experiências concretas, inclusive no Estado de São Paulo, comprovam que é possível conciliar os interesses do ambiental com os modos de vida das comunidades tradicionais, a exemplo de mecanismos formais e de acordos negociados entre gestão e moradores.

(...) a presença de pequenos grupos nativos nas UC é possível e desejável de ser mantida sem prejuízo à conservação dos recursos naturais se houver uma gestão compartilhada, construindo acordos de uso dos recursos naturais, baseados no ordenamento territorial, entre usuários diretos e agentes governamentais, em arenas locais de decisão mantidas através do tempo, em consonância com todo o processo (SIMÕES, 2010, p. 338).

A institucionalização dos acordos já firmados entre as comunidades e a gestão do PEIC, que são frágeis justamente porque não são devidamente reconhecidos pelas instâncias superiores, possibilitaria a garantia de direitos reais para essas comunidades, além de garantir também direitos reais de preservação do ponto de vista dos recursos naturais.

As comunidades do PEIC, em especial o Marujá, conseguiram garantir alguns desses direitos ao longo dos anos e hoje são modelo de referência quando se fala em gestão compartilhada em unidade de conservação. No entanto, é preciso reconhecer que uma verdadeira gestão compartilhada dividiria com as comunidades a responsabilidade pela decisão final sobre todos os assuntos. Seria uma maneira de garantir, por um lado, a sobrevivência das comunidades e, por outro lado, a preservação dos recursos naturais, assegurando as devidas garantias a ambas as partes. A ideia de que a natureza precisa ser resguardada do homem já está ultrapassada há muito tempo. Essa gestão compartilhada, aliando parque com moradores tradicionais, poderia construir instituições ainda mais fortes, realmente adaptadas às realidades e necessidades locais, tanto no que diz respeito à conservação quanto à cultura e ao modo de vida. Se o conselho gestor do PEIC, com todas as suas limitações, pode ser considerado uma instituição robusta, democrática e, sobretudo, um espaço político, como seria se tivesse real poder de deliberação em todos os assuntos? 


\section{REFERÊNCIAS BIBLIOGRÁFICAS}

ABERS, Rebecca Abers (Org.) Água e Política: atores, instituições e poder nos Organismos Colegiados de Bacia Hidrográfica no Brasil. São Paulo: Annablume, 2010.

Abers, Rebecca, and Margaret E. Keck. Representando a diversidade: Estado, sociedade e "relações fecundas" nos conselhos gestores. Caderno CRH 21.52 (2008).

ABRAMOVAY, Ricardo. Conselhos além dos limites. Estudos Avançados, São Paulo, 43 (15), 2001.

ABRAMOVAY, Ricardo. Desenvolvimento rural territorial e capital social. Eric SABOURIN e Olívio TEIXEIRA. Planeamento e desenvolvimento dos territórios rurais: controvérsias e experiências. Brasília: UFPB/CIRAD/EMBRAPA, pp. 113--128, 2002.

ABREU, Mônica C Sá; MESQUITA, Maria do Socorro Silva; SILVA FILHO, José Carlos Lázaro. Análise institucional da gestão ambiental pública no semiárido nordestino: o caso do município de Independência - CE. In: Revista Desenvolvimento em questão. Unijuí: Editora unijuí. Ano 12, n26, abr/jun. São Paulo, 2014.

ACSELRAD, Henri. Justiça ambiental: ação coletiva e estratégias argumentativas. In. ACSELRAD, Henri; HERCULANO, Selene; PÁDUA, José Augusto (Orgs.). Justiça ambiental e cidadania . 2. ed. Rio de Janeiro: Relume Dumará; Fundação Ford, 2004. p. 23-39.

ACSELRAD, Henri. Ambientalização das lutas sociais - o caso do movimento por justiça ambiental. Revista Estudos Avançados, v. 24, n? 68, 2010.

ADAMS, Cristina. Caiçaras na Mata Atlântica - pesquisa científica versus planejamento e gestão ambiental. São Paulo: Annabume : FAPESP, 2000.

MARTÍNEZ ALIER, J. Ecologismo dos pobres. São Paulo: Contexto, 2012.

ARMITAGE, D., F. Berkes, and N. Doubleday. Introduction: moving beyond comanagement. In D. Armitage, F. Berkes, and N. Doubleday, editors. Adaptive comanagement: collaboration, learning and multi-level governance. University of British Columbia Press, Vancouver, British Columbia, Canada, 2007.

AYRES, Heloisa Ferraz e IRVING, Marta Azevedo. 0 olhar psicossocial para a gestão participativa de áreas protegidas: refletindo sobre as possibilidades e desafios. In: IRVING, Marta de Azevedo (org.). Áreas Protegidas e Inclusão Social: Construindo Novos Significados. Rio de Janeiro, Aquarius, 2006. 
AVRITZER, Leonardo. Sociedade Civil, Instituições Participativas e Representação: da Autorização à Legitimidade da Ação. Revista de Ciências Sociais, Rio de Janeiro, Vol. 50, no 3, 2007, pp. 443 a 464.

BALÉE, W. Footprints of the Forest: Ka'apor ethnobotany - the historical ecology of plant utilization by na Amazonia People. New York: Columbia university Press, 1993.

BANDEIRA, Pedro. Participação, Articulação de Atores Sociais e Desenvolvimento Regional. IPEA- Texto para discussão № 630. Brasília, 1999.

BECCATO, Maria Angélica Barbosa. Elaboração Participativa de uma Proposta de Reestruturação do Sistema de Tratamento de Esgoto da Comunidade do Marujá Parque Estadual da Ilha do Cardoso/SP. Dissertação de Mestrado, Escola de Engenharia de São Carlos/ USP, São Carlos, 2004.

BENSUA, Nurit. Conservação da biodiversidade em áreas protegidas. Rio de Janeiro: Editora FGV, 2014.

BERKES, F. Sistemas sociais, sistemas ecológicos e direitos de apropriação de recursos naturais. In: VIEIRA, P.F.; BERKES, F. \& SEIXAS, C.S. Gestão integrada e participativa de recursos naturais: conceitos, métodos e experiências. Florianópolis: Secco/APED, 2005. p.47-72.

BOTELHO, Eloise Silveira. Conflitos na gestão de parques: o caso do Conselho do Parque Estadual dos Três Picos (RJ). Dissertação, Programa Eicos/UFRJ, 2009.

BRASIL. Constituição da República Federativa do Brasil de 1988. Disponível em <http://www.planalto.gov.br/ccivil_03/constituicao/constituicaocompilado.htm>. Acesso em: 30/01/2015.

BRASIL. Lei Federal n.ำ 9.985, de 19 de julho de 2000. Dispõe sobre o Sistema Nacional de Unidades de Conservação da Natureza (SNUC).

BRASIL Decreto 5758, de 13 de abril de 2006. Institui o Plano Estratégico Nacional de Áreas Protegidas - PNAP. < http://www.planalto.gov.br/ccivil_03/_Ato20042006/2006/Decreto/D5758.htm>. Acesso em: 30/01/2015.

BRASIL Decreto 6040, de 7 de fevereiro de 2007. Institui a Política Nacional de Desenvolvimento Sustentável dos Povos e Comunidades Tradicionais. < http://www.planalto.gov.br/ccivil_03/_ato2007-2010/2007/decreto/d6040.htm>. Acesso em: 30/01/2015. 
CAMPOLIM, Marcos Buhrer; PARADA, Isadora Le Senechal; YAMAKA, Juliana Grecco. Gestão Participativa da Visitação Pública na Comunidade do Marujá - Parque Estadual da Ilha do Cardoso. In: IF Série Registros n.33: 33-49. São Paulo: Instituto Florestal, 2008.

CAMPOLIM et al. Ordenamento da visitação pública da praia do Itacuruçá/Pereirinha, Parque Estadual da Ilha do Cardoso, Cananéia - SP . In: II Encontro Fluminense de Uso Público em Unidades de Conservação. Turismo, recreação e educação: caminhos que se cruzam nos parques, 2015, Niterói, RJ. Anais do... Niterói: 2015, p. 48-58.

CANELADA, G. V. M., JOVCHELEVICH P. Manejo agroflorestal das populações tradicionais na Estação Ecológica Juréia-Itatins. Em: Congresso Nacional sobre Essências Nativas, 2, 1992, São Paulo. p. 913-919.

CIFUEnTES, M.. Determinación de Capacidad de Carga Turística en Áreas Protegidas. Centro Agronómico Tropical de Investigación y Enseñanza (CATIE) Serie Técnica, Informe Técnico No. 194. Turrialba, Costa Rica. 1992.

COELHO, Vera Schattan P. e NOBRE, Marcos. (orgs). Participação e deliberação: Teoria Democrática e Experiências Institucionais no Brasil Contemporâneo. São Paulo: Editora 34, 2004.

CÔRTES, Soraya Vargas. Viabilizando a participação em conselhos de política pública municipal: arcabouço institucional, organização do movimento popular e policy communities. (p 125-143). In: Hochman, Gilberto; Arretche, Marta; Marques, Eduardo (org). Políticas Públicas no Brasil. Rio de Janeiro: Editora FIOCRUZ, 2007.

CRAWFORD, Sue E. S. e OSTROM, Elinor. A Grammar of Institutions. The American Political Science Review, Vol. 89, No. 3. (Sep., 1995), pp. 582-600.

DAGNINO, Evelina. “ $i$ Sociedade civil, participação e cidadania: de que estamos falando?". In: MATO, D. Políticas de ciudadanía y sociedad civil em tiempos de globalización. Caracas:FACES, Universidad Central de Venezuela, 2004.

DIEGUES Antônio Carlos Sant'Ana. A Pesca Artesanal No Litoral Brasileiro : Cenários E Estratégias Para Sua Sobrevivência. São Paulo: Centro de Culturas Marítimas, Universidade de São Paulo, 1988. 
Repensando e recriando as formas de apropriação comum dos espaços e recursos naturais. In: DIEGUES, A.C. e MOREIRA, A.C. (org.). Espaços e Recursos Naturais de Uso Comum. São Paulo: NUPAUB/USP, 2001.

DIEGUES, A.C. e ARRUDA, R. S. V. Saberes tradicionais e biodiversidade no Brasil. Brasília: MMA; São Paulo: USP, 2001.

DIETZ, T., E. Ostrom, and P. C. Stern. The struggle to govern the commons. Science 302, 2003, p. 1907-1912.

DUDLEY, N. Guidelines for Applying Protected Area Management Categories. Gland, Suíça: IUCN, 2008.

EHLERS, Eduardo M. Determinantes da Recuperação da Mata Atlântica no Estado de São Paulo. Tese de doutorado apresentada ao Programa de Pós-Graduação em Ciência Ambiental da Universidade de São Paulo. São Paulo, 2003.

FEENY, D.; BERKES, F.; McCAY, B. J.; ACHESON, J.M. (1990). The tragedy of the Commons: twenty-two years later. Human Ecology, 18 (1), 1990, p. 1-9.

FERREIRA, Lucia da Costa et al. Conflitos sociais em áreas protegidas no Brasil: moradores, instituições e ONGs no Vale do Ribeira e Litoral Sul, SP. Ideias. 2002. 8(2), p. 115-150.

GOHN, Maria da Glória. Conselhos gestores e participação sociopolítica. São Paulo, Cortez, 2003.

GOLDMAN, Michael. Inventando os comuns. In: DIEGUES, A.C. e MOREIRA, A.C. (org.). Espaços e Recursos Naturais de Uso Comum. São Paulo: NUPAUB/USP, 2001.

GOMES-POMPA, A.; KAUS, A. 1992. Taming the wilderness myth. Riverside, Bioscience $42(4)$.

HAESBAERT, Rogério. Territórios Alternativos. Contexto, São Paulo, 2002.

0 mito da desterritorialização: do "fim dos territórios" à multiterritorialidade. $2^{\underline{a}}$ ed. rev. Rio de Janeiro: Bertrand Brasil, 2009.

HILL, Michael. Implementação: uma visão geral. In: SARAIVA, Enrique e FERRAREZI, Elisabete (Org.). Políticas Públicas: Coletânea - Volume 2. Brasília: ENAP, 2006. 
IMPERIAL, M. T. Institutional Analysis and Ecosystems-Based Management: The Institutional Analysis and Development Framework. Environmental Management 24: 449-465, 1999.

IRVING, Marta de Azevedo. Construção de governança democrática: interpretando a gestão de parques nacionais no Brasil. In: IRVING, Marta de Azevedo (org.). Áreas Protegidas e Inclusão Social: Construindo Novos Significados. Rio de Janeiro, Aquarius, 2006.

Ecoturismo em áreas protegidas: um desafio no contexto brasileiro. In: IRVING, M.A. e AZEVEDO J. (org) Turismo: o desafio da sustentabilidade. São Paulo: Futura, $2002(\mathrm{~A})$.

Participação: questão central na sustentabilidade. In: IRVING, M.A. e AZEVEDO J. (org) Turismo: o desafio da sustentabilidade. São Paulo: Futura, 2002 (B).

JACOBI, Pedro. Movimento ambientalista no Brasil. Representação social e complexidade da articulação de práticas coletivas. Publicado em Patrimônio Ambiental - EDUSP - 2003.

KINGDON, John. Juntando as coisas. In: SARAIVA, Enrique e FERRAREZI, Elisabete (Org.). Políticas Públicas: Coletânea - Volume 1. Brasília: ENAP, 2006.

LEFF, Enrique. Espaço, Lugar e Tempo: as condições culturais do desenvolvimento sustentável. In: LEFF, E. Saber Ambiental, Sustentabilidade, Racionalidade, Complexidade, Poder. Petrópolis: Vozes, 2001.

MARETTI, Claudio Correa ; RAIMUNDO, S. ; SANCHES, Rosely Alvim ; MARTUSCELLI, Paulo ; CAMPOS, Fausto Pires de . A Construção da Metodologia dos Planos de Gestão Ambiental nas Unidades de Conservação Paulistas. In: I Congresso Brasileiro de Unidades de Conservação, 1997, Curitiba (PR). I Congresso Brasileiro de Unidades de Conservação, 1997.

MARINHO, Maurício de Alcântara. Territorialidade e governança em áreas protegidas: o caso da comunidade do Marujá, no Parque Estadual da Ilha do Cardoso (Cananeia, SP). Tese de doutorado, FFLCH/USP, 2013.

MARQUES, E. Redes sociais, segregação e pobreza. São Paulo: EDUSP, 2010.

MCCORMICK, John. Rumo ao Paraíso - A história dos movimentos ambientalistas. Relume-Dumarã, Rio de Janeiro, 1992. 
McGINNIS, M. D. Networks of Adjacent Action Situations in Polycentric Governance. Policy Studies Journal, 39: 51-78, 2011.

MEDEIROS, Rodrigo; IRVING, Marta Azevedo; GARAY, Irene. Áreas protegidas no Brasil: interpretando o contexto histórico para pensar a inclusão social. In: IRVING, Marta de Azevedo (org.). Áreas Protegidas e Inclusão Social: Construindo Novos Significados. Rio de Janeiro, Aquarius, 2006.

MENDONÇA, Ana Lúcia. A Ilha do Cardoso: o parque estadual e os seus moradores. Dissertação de Mestrado, ESALQ/USP, 2000.

MEYERS, Marcia e VORSANGER, Susan. Burocratas de nível de rua e a implementação de políticas públicas. In: PETERS, Guy e PIERRE, Jon (org.). Administração pública: coletânea. São Paulo: Editora da UNESP; Brasília: ENAP, 2010.

MINISTÉRIO DO MEIO AMBIENTE - MMA. Convenção sobre a Diversidade Biológica. 2000 .

MINISTÉRIO PÚBLICO FEDERAL (MPF). Territórios de povos e comunidades tradicionais e as unidades de conservação de proteção integral: alternativas para o asseguramento de direitos socioambientais. Brasília : MPF, 2014.

OSTROM, Elinor. Governing the Commons: The Evolution of Institutions for Collective Active. New York: Cambridge University Press, 1990.

Understanding institutional diversity. United Kingdom: Princeton University Press, 2005.

A diagnostic approach for going beyond panaceas. In: PNAS, vol. 104 (39), 2007, p. 15181-15187.

Beyond Markets and States: polycentric governance of complex economic systems. In: American Economic Review 100, June 2010, p. 641-672.

OSTROM, Elinor; McKEAN, Margaret. Regimes de propriedade comum em florestas: somente uma relíquia do passado? In: DIEGUES, Antonio Carlos; MOREIRA, André de Castro (Org.). Espaços e recursos naturais de uso comum. São Paulo: NupaubUSP, 2001. p. 79-95.

PINKERTON, Evelyn. Attaining better fisheries management through comanagement prospects, problems and propositions. In: Pinkerton, E. (Ed.), Cooperative Management of Local Fisheries: New Direction in Improved Management and 
Community Development. University of British Columbia Press, Vancouver, BC, 1989, pp. $3-33$.

PINTO, Daniel Mendes. O Uso de Recursos de Propriedade Comum em Áreas de Propriedade Estatal por Populações Tradicionais e Assentados da Reforma Agrária. Tese UF Brasília, 2014.

RAFFESTIN, Claude. Por uma geografia do poder. Tradução de Maria CecíliaFrança. São Paulo: Ática, 1993.

RAIMUNDO, Sidnei. As Ondas do Litoral Norte (SP): Difusão espacial das práticas caiçaras e do veraneio no Núcleo Picinguaba do Parque Estadual da Serra do Mar (1966-2001). Tese (Doutorado). UNICAMP, Instituto de Geociências. Campinas, SP, 2007.

RAIMUNDO, S. ; MATHEUS, F. S. . A gestão e o desenvolvimento do ecoturismo nas áreas protegidas estaduais de São Paulo, Brasil. In: Fernando Perna; Pedro Gouveia; Francisco Serra; José Santos; Paulo Águas. (Org.). Economia, Ambiente e Sustentabilidade no Turismo. 1ed.Algarve (Portugal): UAIg ESGHT. Universidade do Algarve, 2013, v. 1, p. 17-30.

RODRIGUES, Carmem Lúcia. Limites do Consenso: territórios polissêmicos na Mata Atlântica e gestão ambiental participativa. Tese de doutorado, FFLCH/Universidade de São Paulo, 2001.

SANTOS JUniOR, O. A; AZEVEDO, S.; RIBEIRO, L C. Q. Democracia e Gestão local: A experiência dos conselhos municipais no Brasil. In: Governança. democracia e poder local. Rio de Janeiro: Editora Revan, 2004.

SÃO PAULO. SECRETARIA DE ESTADO DE MEIO AMBIENTE (SMA). Decreto estadual no 40.319, de 3 de julho de 1962. Disponível em < http://governosp.jusbrasil.com.br/legislacao/224425/decreto-40319-62>. Acesso em: 30/11/2014.

SECRETARIA DE ESTADO DE MEIO AMBIEnTE (SMA). Plano de Manejo do Parque Estadual da Ilha do Cardoso - Fase 2. Projeto de Preservação da Mata Atlântica (Cooperação Financeira Brasil - Alemanha). KFW: Instituto Florestal. Secretaria de Estado do Meio Ambiente. São Paulo, 2001.

SECRETARIA DE ESTADO DE MEIO AMBIENTE (SMA). Decreto estadual no 49.672, de 6 de junho de 2005. Dispõe sobre a criação dos Conselhos Consultivos das Unidades de Conservação de Proteção Integral do Estado de São Paulo. Disponível em <http://www.ambiente.sp.gov.br/wp-content/uploads/decreto/2005/2005-Dec49672.pdf>. Acesso em: 30/01/2015. 
SÃO PAULO. SECRETARIA DE ESTADO DE MEIO AMBIENTE (SMA). Decreto estadual no 51.453, de 29 de dezembro de 2006. Cria do Sistema Estadual de Florestas - SIEFLOR. Disponível em <http://www.cetesb.sp.gov.br/licenciamentoo/legislacao/estadual/ decretos/2006_dec_est_51453.pdf>. Acesso em: 30/01/2015.

SCHNEIDER, Sergio; SILVA, Marcelo Ka; Marques, Paulo E. Moruzzi. Políticas públicas e participação social no Brasil rural. Porto Alegre: Editora da UFRGS; 2004.

SIMÕES, Eliane. O Dilema das Decisões sobre Populações Humanas em Parques: Jogo compartilhado entre Técnicos e Residentes no Núcleo Picinguaba. Tese (Doutorado). Campinas, 2010.

SINGER, Paul. Introdução à Economia Solidária. SP: Fundação Perseu Abramo, 2002.

SUBIRATS, Joan. El papel de la burocraia em el processo de determinación e implemntación de las políticas publicas. In: SARAIVA, Enrique e FERRAREZI, Elisabete (Org.). Políticas Públicas: Coletânea - Volume 2. Brasília: ENAP, 2006.

THIOLENT, M.; SILVA, G.O. Metodologia de pesquisa-ação na área de gestão de problemas ambientais. RECIIS - R. Eletr. de Com. Inf. Inov. Saúde, Rio de Janeiro, v.1, n.1, p. 93-100, jan.- jun., 2007. Disponível em: <www.reciis.cict.fiocruz.br>. Acesso em: jun 2011.

VAZ, Alexander Cambraia N. Da participação à qualidade da deliberação em fóruns públicos: o itinerário da literatura sobre conselhos no Brasil. Em PIRES, Roberto Rocha C. (Org.) Efetividade das Instituições Participativas no Brasil: estratégias de avaliação.Brasília: IPEA, 2011. (Diálogos para o desenvolvimento).

VIEIRA, Paulo Freire; BERKES, Fikret; SEIXAS, Cristiana S. Gestão integrada e participativa de recursos naturais: conceitos, métodos e experiências. Florianópolis: Secco/APED. 2005.

WINTER, Soren. Perspectivas de implementação: status e reconsideração. In: PETERS, Guy e PIERRE, Jon (org.). Administração pública: coletânea. São Paulo: Editora da UNESP; Brasília: ENAP, 2010.

ZHOURI, A.; LASCHEFSKI, K.; PEREIRA, D.B. Introdução: desenvolvimento, sustentabilidade e conflitos socioambientais. In: A insustentável leveza da política ambiental: desenvolvimento e conflitos socioambientais. Belo Horizonte: Autêntica, 2005. 
VIANNA, Lucila Pinsard. De invisíveis a protagonistas: populações tradicionais e unidades de conservação. ANNABLUME, FAPESP, São Paulo, 2008.339p. 


\section{APÊNDICES}

\section{Apêndice A - Instrumento de coleta de informações semistruturado}

\section{Público alvo: Conselheiros do Conselho Gestor do PEIC}

\section{Roteiro de Entrevista}

$\checkmark$ Apresentação do projeto e termo de consentimento da entrevista.

$\checkmark$ Dados pessoais do entrevistado.

$\checkmark$ Idade / Profissão / Quanto tempo vive na comunidade.

\section{PARTE 1 - INFORMAÇÕES SOBRE A COMUNIDADE}

1. Poderia me contar brevemente o histórico da comunidade?

2. Quais os principais desafios enfrentados hoje pela comunidade? Como a comunidade lida com esses desafios?

$\checkmark$ De forma individual e coletiva.

3. Poderia me dar um breve histórico da Associação? (AMOMAR, AMOIP , AMEB)

4. Quais são os principais objetivos da Associação? Você acha que esses objetivos têm sido alcançados?

$\checkmark$ Como são as reuniões? Quem participa?

$\checkmark$ Quanto há divergência de opiniões, como são resolvidos os assuntos?

$\checkmark$ As informações da associação estão disponíveis a toda a comunidade?

5. Existem atividades que são feitas coletivamente na comunidade? Como se dá a participação dos moradores nessas atividades?

6. Quais são as regras que vigoram na comunidade, entre os próprios moradores, e em relação a pessoas/grupos/comunidades de fora?

$\checkmark$ Regras formais e informais / acordos coletivos.

$\checkmark$ Os moradores cumprem essas regras?

$\checkmark$ Como foram discutidas essas regras? O que acontece com os moradores que descumprem as regras?

7. Como é a relação da comunidade com a gestão do parque?

$\checkmark$ Como você vê as mudanças de gestão? Isso influencia de alguma maneira a relação que a comunidade tem com o parque?

8. Há instituições que de alguma maneira apoiam ou são parceiros da comunidade?

$\checkmark$ Quem são? Como se dá a relação com essas instituições?

9. Como é a relação da comunidade com as outras comunidades do parque?

$\checkmark$ Há algum acordo ou já houve algum esforço de integração entre as comunidades para alcançar algum objetivo específico?

\section{PARTE 2 - INFORMAÇÕES SOBRE O CONSELHO}

10. A Associação/Comunidade tem participado ativamente do conselho? Por que?

11. Qual o papel do conselheiro? Voce acha que esse papel tem sido cumprido? 
$\checkmark N a$ sua opinião, para que serve um conselho gestor de um parque? Voce acha que o conselho cumpre seus objetivos?

12. Quais os principais desafios que o conselho enfrenta atualmente?

$\checkmark$ Voce acha que houve mudanças no funcionamento do conselho desde a sua formação? Se sim, quais mudanças. Se não, por que?

13. 0 que você acha que poderia contribuir para melhorar o funcionamento do conselho?

14. Quais são os membros que participam mais dentro do conselho? E os que participam menos? Quem você acha que deveria participar mais?

15. As reuniões acontecem de maneira a facilitar a participação das pessoas?

$\checkmark$ O que seria necessário para que as pessoas participassem mais das reuniões?

16. Os membros entendem os assuntos que são discutidos nas reuniões?

$\checkmark$ (pensar em linguagem, informações técnicas)

$\checkmark$ As informações (do conselho, do parque, das decisões) estão disponíveis a todos os conselheiros?

17. Voce tem conhecimento a respeito das regras que vigoram no âmbito do conselho?

$\checkmark$ Conhece o regimento interno?

$\checkmark$ E no âmbito do Parque Estadual? Voce tem conhecimento das normas, decretos e leis?

18. Como se dá o processo de decisão dentro do conselho? Quando há divergências, como os assuntos são resolvidos?

$\checkmark$ Os assuntos decididos no âmbito do conselho são postos em prática?

19. Há algum tipo de decisão que é tomada fora do conselho? Onde e como ocorrem essas decisões?

20. Como se dá a interação com os outros membros do conselho?

$\checkmark$ Há algum tipo de interação com os outros membros fora do conselho?

$\checkmark$ E com é a interação com o gestor?

21. Na sua opinião, qual o papel do gestor? Considerando o histórico de gestão do PEIC, como você analisa a atuação e o papel do gestor...

$\checkmark$ Em relação à comunidade?

$\checkmark$ Em relação aos conflitos?

$\checkmark$ Em relação à participação das comunidades na gestão do parque?

22. A comunidade conhece o conselho? As informações do conselho estão disponíveis para a comunidade poder acompanhar?

23. Que outros mecanismos ou espaços poderiam contribuir para aumentar a participação das comunidades na gestão do parque?

24. O que é a comunidade XXX (Itacuruçá/Pereirinha, Marujá, Enseada da Baleia) para você?

25. 0 que é o Parque Estadual Ilha do Cardoso para você?

\section{Público alvo: membros da comunidade}

\section{Roteiro de Entrevista}

$\checkmark$ Apresentação do projeto e termo de consentimento da entrevista.

$\checkmark$ Dados pessoais do entrevistado.

$\checkmark$ Idade / Profissão / Quanto tempo vive na comunidade. 
1. Poderia me contar brevemente o histórico da comunidade?

2. Quais os principais desafios enfrentados hoje pela comunidade? Como a comunidade lida com esses desafios?

$\checkmark$ De forma individual e coletiva.

3. Existem projetos comunitários? Se sim, como são desenvolvidos? Quem participa?

4. Quais atividades são feitas coletivamente na comunidade?

$\checkmark$ Como se dá a participação dos moradores nessas atividades?

$\checkmark$ Quais os espaços onde essas decisões são tomadas?

$\checkmark$ Como é a distribuição de responsabilidades?

5. Como são tomadas as decisões coletivas sobre a comunidade?

$\checkmark$ As decisões são tomadas em reuniões ou encontros?

$\checkmark$ Como são essas reuniões? Quem participa?

$\checkmark$ Quando há divergência de opiniões, como os assuntos são tratados?

$\checkmark$ Voce acha que as informações estão disponíveis para toda a comunidade?

$\checkmark$ A maioria dos moradores participam das decisões ou elas são tomadas apenas por algumas pessoas?

6. Quais são as regras que vigoram na comunidade, entre os próprios moradores, e em relação a pessoas/grupos/comunidades de fora?

$\checkmark$ Regras formais e informais / acordos coletivos.

$\checkmark$ Os moradores cumprem essas regras?

$\checkmark$ Como foram discutidas essas regras? O que acontece com os moradores que descumprem as regras?

7. Como é a relação da comunidade com a gestão do parque?

$\checkmark$ Como você vê as mudanças de gestão? Isso influencia de alguma maneira a relação que a comunidade tem com o parque?

$\checkmark$ Voce acha que os interesses e anseios da comunidade são levados em consideração pela gestão?

$\checkmark$ Na sua opinião, a comunidade consegue participar da gestão do parque? De que maneira? Se não, por que?

8. Há instituições que de alguma maneira apoiam ou são parceiros da comunidade?

$\checkmark$ Quem são? Como se dá a relação com essas instituições?

9. Como é a relação da comunidade com as outras comunidades do parque?

$\checkmark$ Há algum acordo ou já houve algum esforço de integração entre as comunidades para alcançar algum objetivo específico?

10. Voce tem conhecimento a respeito das regras que vigoram no âmbito do Parque Estadual?

$\checkmark$ Voce tem conhecimento das normas, decretos e leis?

11. Voce tem conhecimento do funcionamento do conselho? E das decisões que são tomadas no conselho?

$\checkmark$ Na sua opinião, para que serve um conselho gestor de um parque? Voce acha que o conselho cumpre seus objetivos?

12. Qual o papel do gestor? Considerando o histórico de gestão do PEIC, como você analisa a atuação e o papel do gestor...

$\checkmark$ Em relação à comunidade?

$\checkmark$ Em relação aos conflitos?

$\checkmark$ Em relação à participação das comunidades na gestão do parque? 
13. 0 que é a comunidade para você?

14. 0 que é o Parque Estadual Ilha do Cardoso para você?

\section{Público alvo: ex gestor do PEIC}

\section{Roteiro de Entrevista}

1. Breve histórico da relação com o PEIC.

2. Como você analisa/ocorre a participação da sociedade no conselho?

3. Qual é o poder do conselho nas tomadas de decisões?

$\checkmark$ O modo como hoje ocorre está divisão de poder está adequado?

$\checkmark$ O senhor acredita que os membros do Conselho tem poder suficiente?

$\checkmark$ Poder como tomada de decisões.

$\checkmark$ fato do conselho ser consultivo ou deliberativo tem influenciado o desempenho do conselho?

4. Além do conselho, quais são os outros espaços de decisões e acordos?

5. Relação das comunidades com o parque.

6. Relação das comunidades entre as próprias comunidades.

7. Qual o papel do conselho? E dos conselheiros?

8. Qual o papel do gestor? Considerando o histórico de gestão do PEIC, como você analisa a atuação e o papel do gestor...

$\checkmark$ Em relação à comunidade?

$\checkmark$ Em relação aos conflitos?

$\checkmark$ Em relação à participação das comunidades na gestão do parque?

9. Mudanças de gestor influenciam a participação, as comunidades...

10. As comunidades conseguem participar da gestão do parque?

$\checkmark$ Há diferenças de participação entre elas?

$\checkmark$ O modo como estão organizadas influenciam nessa participação?

11. Como você explica o PEIC ser considerado modelo de referência de gestão? Que fatores explicam esse êxito? 


\section{Apêndice B - Termo de Consentimento Livre e Esclarecido}

\section{TERMO DE CONSENTIMENTO LIVRE E ESCLARECIDO}

O sr(a) está sendo convidado(a) para participar da pesquisa intitulada: Mecanismos de participação das comunidades locais na gestão de Unidades de Conservação. Meu nome é Paula Fernanda do Valle, sou mestranda no Programa de Mudança Social e Participação Política da Universidade de São Paulo - USP e responsável pela realização desta pesquisa, junto ao meu orientador Prof. Dr. Sidnei Raimundo.

Após receber os esclarecimentos e as informações a seguir, no caso de aceitar fazer parte do estudo, assine ao final deste documento, que está em duas vias de igual teor. Uma delas é sua e a outra é do pesquisador responsável. Em caso de dúvida sobre a pesquisa, você poderá entrar em contato comigo pelo e-mail paulavalle@usp.br ou pelo telefone (11) 98538-9862. Você será esclarecido(a) sobre a pesquisa em qualquer aspecto que desejar.

O objetivo desta pesquisa é compreender a participação das comunidades caiçaras que residem nos limites do Parque Estadual Ilha do Cardoso na gestão do parque. Sua participação nesta pesquisa consistirá em responder as perguntas a serem realizadas sob a forma de entrevista. A entrevista terá duração aproximada de 60 minutos e será gravada em gravador digital para posterior transcrição. Sua participação é voluntária.

O benefício relacionado à sua participação será o de aumentar o conhecimento científico para as áreas das Ciências Sociais, Turismo, Geografia e outras interessadas em compreender a dinâmica existente em Parque Estadual, a exemplo do Parque Estadual Ilha do Cardoso, para colaborar com o desenvolvimento de mecanismos que visem a melhoria da qualidade de vida de suas populações.

A qualquer momento você poderá recusar-se a responder qualquer pergunta ou desistir de participar e retirar seu consentimento. Sua recusa não trará nenhum prejuízo em sua relação com a pesquisadora ou com a instituição na qual você trabalha.

O Sr (a) terá amplo acesso ao material editado (transcrição na integra) e também ao relatório produzido, podendo sugerir alterações. O sr (a) poderá solicitar, a qualquer momento, a supressão de seus depoimentos usados no relatório. O sr (a) receberá a transcrição na integra da entrevista, e se estiver de acordo irá assiná-la para e devolve-la para o pesquisador. A pesquisadora se compromete a deixar uma cópia do resultado final da pesquisa para o entrevistado no Conselho Gestor do Parque Estadual Ilha do Cardoso até dezembro de 2016.

O Sr.(a) pode permitir ou não permitir o uso de seu nome ou material que identifique sua participação nesta pesquisa, assinalando uma das opções abaixo:

$\square$ Permito ser identificado como participante desta pesquisa.

$\square$ Permito que apenas as iniciais do meu nome apareçam nesta pesquisa.

$\square$ Não permito ser identificado nesta pesquisa, solicitando que depoimento não seja identificado.

Declaro estar ciente do inteiro teor deste TERMO DE CONSENTIMENTO e estou de acordo em participar do estudo proposto, sabendo que dele poderei desistir a qualquer momento, sem sofrer qualquer punição ou constrangimento. Recebi uma cópia assinada deste formulário de consentimento.

Colaborador da Pesquisa

Nome:

RG:

(Assinatura e data)
Responsável pela pesquisa

Nome: Paula Fernanda do Valle

RG: $32.847 .485-\mathrm{X}$

(Assinatura e data) 